\title{
Laboulbeniales (Ascomycetes) of Finland and adjacent parts of the U.S.S.R.
}

\author{
LARRY HULDÉN
}

HULDÉN, L. 1983: Laboulbeniales (Ascomycetes) of Finland and adjacent parts of the U.S.S.R. - Karstenia 21: 31-136.

About 160000 specimens of insects, belonging to 1100 species, and a few millipedes, mostly from museum collections, were investigated with respect to the occurrence of ectoparasitic, laboulbeniaceous fungi in Finland and adjacent parts of the U.S.S.R. In all 166 species of insects (Coleoptera and Diptera) were found to be infested by 88 taxa of Laboulbeniales ( 81 species from Finland and 42 species from the U.S.S.R.), all are reported from the area for the first time. All the fungus taxa are illustrated and their distribution mapped. Twenty-four taxa are described as new for science: Cantharomyces aploderi n. sp., Dichomyces furcifer subsp. subarcticus n. subsp., Eucantharomyces fennoscandicus n. sp., Fanniomyces copromyzae n. sp., Hydrophilomyces arcuatus n. sp., Laboulbenia carelica n. sp., L. fennica n. sp., L. hastiana n. sp., L. kajanensis n. sp., L. murmanica n. sp., L. oodiphila n. sp., Monoicomyces oxyteli n. sp., Siemaszkoa fennica n. sp., Stigmatomyces axystae n. sp., S. bottnica n. sp., S. chthonicus n. sp., S. dichaetae n. sp., S. hackmanii n. sp., S. manicatae n. sp., S. mantis n. sp., S. setacerae n. sp., $S$. subterraneus n. sp., Symplectromyces lapponicus n. $\mathrm{sp}$. and $S$. rarus $\mathrm{n}$. sp. Five other species are recorded for the first time from Europe: Laboulbenia compressa Thaxter, $L$. curtipes Thaxter, L. manubriolata Thaxter, Monoicomyces furcata Thaxter and Teratomyces brevicaulis Thaxter.

A short review is given of the morphology, host-parasite relationships, distribution, origin and taxonomy of the parasites of the Laboulbeniales. The general conditions for the occurrence of laboulbeniaceous parasites are discussed. The frequency of these parasites on insects in Northern Europe proved to be about $1 \%$, which is very low compared with the values for Central Europe, where the frequency is generally $10-$ $35 \%$. The explanation appears to be that in the north the host populations are smaller, more scattered and living under more unpredictable climatological conditions, which lowers the probability of establishment, dispersal and survival of the parasites. This is probably also the reason why many parasites do not extend as far north as their hosts, though another explanation may be an alteration in the life cycle pattern of the host towards the north. In one case, at least, viz. Misgomyces dyschirii Thaxter on Dyschirius globosus (Herbst), the distribution of the parasite is apparently directly limited by certain climatological factors.

Preliminary results of investigations of Laboulbenia fennica occurring on whirligig beetles (Coleoptera, Gyrinidae) in several host populations in southern Finland have shown a very constant frequency of the parasite, with no seasonal variation. In contrast, investigations of the Laboulbeniales in Central Europe have revealed two different patterns of population dynamics with distinct seasonal fluctuations.

Larry Huldén, Department of Entomology, Zoological Museum, P. Rautatiekatu 13, $S F-00100$ Helsinki, Finland. 
1. Introduction

2. Morphology and development

2.1. Development of the receptacle

2.2. Appendages

2.3. Male sexual organs

2.4. The perithecium and female sexual organ

2.5. Asci and ascospores

2.6. Life cycle

3. Parasite-host relationships

3.1. Nutrition and pathogenicity

3.2. Transmission and occurrence in host populations

3.3. Host range

3.4. Host specificity

3.5. Position specificity

3.6. Distribution of the Laboulbeniales

4. Systematic position

5. Classification

6. Laboulbeniales-like parasites and hyperparasites

7. Laboulbeniales in Finland and adjacent parts of the U.S.S.R.

7.1. Material and methods

7.2. The study area

7.3. Species composition and host range

7.4. Frequency on the host and distributional patterns

7.5. Population dynamics of Laboulbenia fennica in Finland

7.6. Potential new parasite species in Finland

8. Taxonomic section

8.1. Terminology

8.2. Identification of the species of Laboulbeniales

8.2.1. Key to the genera of the East Fennoscandian Laboulbeniales

8.2.2. Keys to species of East Fennoscandian Laboulbeniales

8.3. Review of the species

8.4. Notes on non-laboulbeniaceous parasites in Finland

8.4.1. Amphoromorpha sp.

8.4.2. A hyperparasite on Laboulbenia argutoris

Acknowledgements

Figures

References

Appendices

\section{Introduction}

The Laboulbeniales are a relatively large order of fungi within the Ascomycetes, with a world-wide distribution and more than 1800 species. All the species are nowadays classified as obligate ectoparasites of Arthropoda, mainly insects, but also mites and millipedes. They are in most cases microscopical, the size varying from $0.04 \mathrm{~mm}$ to about $1 \mathrm{~mm}$. Despite their parasitic habit, they cause little or no harm to the host.

The earliest observations on Laboulbeniales were made by two French entomologists, A. Laboulbéne and A. Rouget, in the 1840 s. Rouget published the first illustrated report on these parasites in 1850 and three years later the first two species were described from France by J. Montagne and C. Robin (Robin 1853). Except for a few papers in the subsequent years, little attention was paid to the Laboulbeniales until 1890, when the famous American mycologist Roland Thaxter published the first of a long series of papers on this fungus group. His most important work was the monograph of the Laboulbeniales, of which five volumes were published in 1896, 1908, 1924, 1926 and 1931. Unfortunately he died before he could prepare the sixth volume, which was intended to be a synthesis of his knowledge of the Laboulbeniales. About two thirds of all the known species have been described by Thaxter. A long series of papers on the Laboulbeniales, mainly from South America and Italy, was published in Argentina by one of Thaxter's contemporaries, the Italian mycologist Carlos Spegazzini (1902-1924). He described nearly 270 new taxa and he is thus one of the most outstanding researchers in this group. Other important names are F. Picard, É. Chatton and C. Cépède (France) and R. Maire (Algeria).

In Europe numerous regional floristic works have been published on the Laboulbeniales during the twentieth century. In addition to the above-mentioned names at least the following ought to be mentioned: R. Baumgartner (Switzerland), J. and W. Siemaszko (Poland), S. Colla (Italy), P. Lepesme (France), Middelhoek (Netherlands), A. Collart (Belgium) and J. Banhegyi (Hungary).

In the 1970 s and early 1980 s important work has been done on the Laboulbeniales by R.K. Benjamin and I.I. Tavares (U.S.A.), J. Balazuc, J. and H. Dainat (France), K. Sugiyama and K. Terada (Japan), W. Rossi and G. Cesari Rossi (Italy), T. Majewski (Poland) and H.-W. Scheloske (Federal Republic of Germany). A few other authors have contributed floristic notes or descriptions of new taxa.

Although about 265 species have been reported from Europe, there are few literature records for Northern Europe. Only 18 species have been reported for Fennoscandia and Denmark, by: (1) Thaxter (1908), (2) Rostrup (1916), (3) Siemaszko \& Siemaszko (1928), (4) Arwidsson (1946), (5) Ryberg (1947), (6) Huggert (1973), (7) Balazuc (1973-74) and (8) Balazuc (1980). These are as follows (the number in brackets refers to the author):

Amphimyces liodivorus Huggert, Sweden (6)

Arthrorhynchus nycteribiae (Peyritsch) Thaxter, Sweden, Denmark (5)

Asaphomyces gillerforsii Huggert, Sweden (6)

A. tubanticus (Middelhoek \& Boelens) Scheloske, Sweden (6)

Colonomyces appendiculatus Benjamin, Sweden (6)

Corethromyces niger Majewski (Laboulbenia ptomaphagi Huggert), Sweden, Denmark (6)

Ecteinomyces agathidii Maire, Sweden (6)

Eumonoicomyces papuanus Thaxter, Denmark (2)

Hydrophilomyces digitatus Picard, Sweden (7)

Laboulbenia colasi Lepesme, Sweden (7)

L. flagellata Peyritsch, Denmark (2)

L. cf. ophoni Thaxter, Sweden (4)

L. cf. polyphaga Thaxter/vulgaris Peyritsch, Sweden (4)

L. pterostichi Thaxter, Denmark (2), Finland (3) 
Rhachomyces philonthinus Thaxter, Sweden (1)

Rickia huggerti Balazuc, Sweden (8)

$R$. hyperborea Balazuc, Norway (8)

Stigmatomyces euconni Picard, Denmark (7)

Briedis (1932) reported 15 species of Laboulbeniales from Latvia. It may be noted that there are only scattered records of Laboulbeniales from Siberia and Canada (Thaxter 1908, Siemaszko \& Siemaszko 1928). From Alaska only one species is known from the Aleutian Islands (Thaxter 1896).

The present study on the Laboulbeniales is the first on this fungus group from Eastern Fennoscandia (Siemaszko's note excluded). The taxa reported from the area number 88 . Of these 23 species and one subspecies are described as new to science and five other species are reported for the first time from Europe. Owing to the scarcity of literature records from northern regions, these observations provide new information on the distribution of the parasites in relation to their hosts and also serve to elucidate the biology of the hosts.

\section{Morphology and development}

This section is mainly based on Benjamin (1971, 1973), where the student of the group can obtain more details. The different developmental stages of the Laboulbeniales are illustrated in Thaxter (1896).

\subsection{Development of the receptacle}

The basal part of the germinating spore darkens and forms a suckerlike organ called the foot. The foot finally becomes black and adheres to the surface of the host, and a short haustorium penetrates the integument and comes into contact with living cells in the host. In a few genera this haustorium may be large and branched with the foot only slightly darkened. After development of the haustorium the spore cells rapidly begin to divide and form the receptacle, i.e. that part of the thallus from which appendages and perithecia develop. The cell divisions take place in a very exact sequence and in a manner typical of the genus. The receptacle normally has a definite number of cells. The complexity of the receptacle varies greatly. It may consist of only three cells, a basal cell, a subbasal cell, which may bear a perithecium or other outgrowths, and an upper cell terminating in an appendage. In other cases it may be composed of one or a few rows of superposed cells and sometimes secondary axes grow from the subbasal cell. The organization of the receptacle is an important character for separating different genera within the order.

\subsection{Appendages}

The primary appendage is a branch originating directly from the upper segment of the spore. It may persist or disappear. Secondary appendages often grow from the receptacle or sometimes from the perithecium. In genera such as Stigmatomyces and Haplomyces the apex of the original upper segment of the spore is readily seen as a distinct spine at the top of the appendage. The structure of the appendages may vary from only one cell to long simple or branched rows of superposed cells, which may bear antheridia. The perithecial appendages are always sterile.

\subsection{Male sexual organs}

In sexual reproduction the carrier of the male genes, the spermatium, originates in three different ways, by exogenous formation, in simple antheridia or in compound antheridia. The exogenous spermatia arise directly, as small rodlike branchlets, on the lateral side of the appendage cells. The simple antheridium in which spermatia are formed endogenously is composed of a flaskshaped cell with attenuated neck, through which the spermatia pass to the outside. This type of spermatia formation is the most common in the Laboulbeniales. Simple antheridia may occur on the appendage singly or in groups of varying size. In many dioecious species the male thallus terminates in a single antheridium with an obliquely placed neck. The antheridia may be free or connected to a varying degree with neighbouring cells or antheridia, sometimes only the discharge tube being free. In the compound antheridium many antheridial cells discharge spermatia into a common chamber with one common discharge opening. Compound antheridia often occur singly, but sometimes there are several of them on the thallus. The antheridia are still unknown in many genera.

\subsection{The perithecium and female sexual organ}

The perithecial cells originate from the lower spore segment. They develope from a single cell somewhere on the receptacle. In most cases this divides into an upper and a lower cell. The upper one forms the female organ while the lower one gives rise to the stalk, base and walls of the perithecium. The female organ consists of a lower carpogenic cell, a median trichophoric cell and a terminal trichogyne. The cells of the perithecial walls grow up around the carpogenic cell and trichophoric cell, the trichogyne being an external structure consisting of one or a few cells, simple or branched. A spermatium from the male organ adheres on some occasion to the trichogyne and the male nucleus moves into the perithecium, where fertilization finally takes place. At maturation of the perithecium, the trichophoric cell and the trichogyne disappear and the carpogenic cell gives rise to one, two, four, eight or more ascogenous cells. In many species the number of ascogenous cells seems to be relatively limited. The ascogenous cells develop in succession, giving rise to four, rarely eight, ascospores each and eventually filling the perithecial cavity. There are some important deviations from the abovementioned process, which have taxonomic implications; for instance Euzodiomyces has additional secondary perithecial stalk cells; for details see Tavares $(1965,1966,1980)$ and Benjamin (1971).

Plasmogamy and meiosis have not been observed in the Laboulbeniales (Alexopoulos \& Mims 1979), but according to Tavares (1965) the nuclei fuse in the asci of at least one studied species. 


\subsection{Asci and ascospores}

The ascospore is more or less elongate, spindle-shaped and two-called, with the septum dividing the spore into two segments, usually unequal in length. Four (rarely eight) spores develop in each ascus, the walls of which deliquesce prior to spore discharge. The longer, basal cell of the spore is directed upwards and emerges first when the spore is discharged from the perithecium. The spores sometimes start to germinate within the perithecium but this process normally begins after they have been discharged from the perithecium. The spores are very often discharged in pairs. They are surrounded by a hyaline envelope, which is thicker in the basal part and which improves the adhesion of the spore to the surface of the host. In dioecious species the female individuals originate from spores which are distinctly larger than the male ones. Asexual spores have never been observed in the Laboulbeniales.

\subsection{Life cycle}

The Laboulbeniales lack extensive mycelium and conidial stages, and reproduction takes place only by means of ascospores. Some old reports of anamorphs (imperfect stages) in the Laboulbeniales are apparently erroneous (cf. Alexopoulos \& Mims 1979). The time required for development from ascospore to the fully grown thallus and the maturation of the perithecium varies in most of the species studied from 10 to 21 days (e.g. Peyritsch 1875, Baumgartner 1934, Lindroth 1948). On the other hand Boyer-Lefévre (1966) found that Rhachomyces aphaenopsis Thaxter, which occurs on a cavernicolous beetle in constantly low temperatures, required nearly six months for maturation. Lindroth (1948) found that the spores not reaching the host were short-lived, persisting for at most two weeks.

\section{Parasite-host relationships}

\subsection{Nutrition and pathogenicity}

The members of the Laboulbeniales obtain all the nutrition and water they need from their host (Benjamin 1971). In culture experiments on artificial media (Richards \& Smith 1954, Whisler 1968), the fungus never completed its development, antheridia were formed at most, but no female organs. These fungi can consequently be regarded as obligate ectoparasites, able to grow only on living hosts. With few exceptions, they have been found only on the imaginal stage of the host. The only part of the fungus that penetrates the surface of the host is the haustorium. If the fungus grows on a larval stage of the host (studied in cockroaches) the infection is lost at ecdysis (Richards $\&$ Smith 1956). The remains of the haustorium cannot regenerate the infection.

The pathogenicity of the Laboulbeniales is very low. However, in cases like the fly in Fig. 112, heavy infestation may influence the behaviour of the host. Kamburov et al. (1967) reported an increased rate of premature mortality in a beetle, Chilocorus bipustula- tus (Linnaeus) (Coleoptera, Coccinellidae), presumably caused by heavy infestation by a laboulbeniaceous fungus. Bro Larsen (1952) found high mortality among Bledius species (Coleoptera, Staphylinidae) infected by a species of the Laboulbeniales in Denmark. Benjamin (1971), however, expressed some doubt about the exact cause of mortality in these cases. Generally, the Laboulbeniales can be regarded as harmless to their hosts.

\subsection{Transmission and occurrence in host populations}

The spores are spread by the activities of the host. As they are adhesive and short-lived they probably cannot spread through the air or over long distances without the presence of a suitable host. The general transmission patterns are illustrated in Fig. 1.

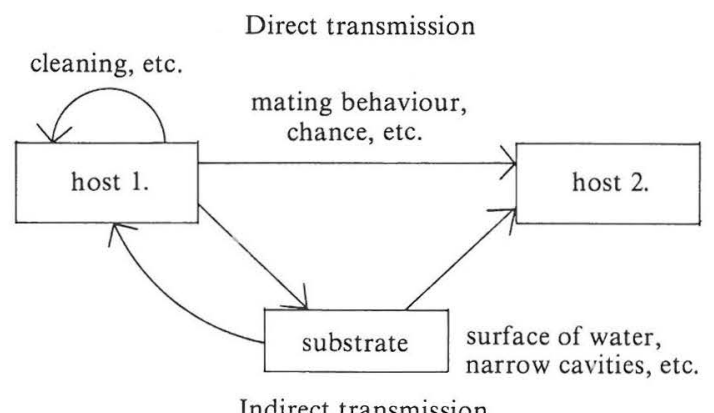

Fig. 1. Transmission patterns of the Laboulbeniales

Direct transmission enables the fungus to persist in a small host population even when the number of spores is limited. Scheloske (1976a, 1976b) described two cases of highly specialized tranmission patterns in which different morphs of the parasite occurred on different sexes of the host. Indirect transmission is presumably more dependent on large host populations and a greater number of spores. Some of the general conditions essential or favourable to the existence of laboulbeniaceous parasites are:

1. A host overwintering at least partially in the imaginal stage;

2. Overlapping between the imaginal stages of the overwintered and the new generations;

3. Mating between members belonging to successive generations of the host, in cases where transmission takes place only during mating (Scheloske 1976a);

4. Large or dense host populations;

5. Low isolation between host populations;

6. Stable host populations;

7. Warmth (the fungus group tends to be more common in warmer regions).

The first three conditions are essential, while the importance of the others can vary. In a highly isolated host population, for instance, the stability of the population is particularly important.

\subsection{Host range}

The species of the Laboulbeniales have been found 
mostly on insects (Insecta) but also on a few millipedes (Diplopoda) and mites (Acari). Among insects, ten orders are involved: Blattodea, Coleoptera, Dermaptera, Diptera, Heteroptera, Hymenoptera, Isoptera, Mallophaga, Orthoptera and Thysanoptera (Benjamin 1971). More than $90 \%$ of the total species and 120 of the 130 genera have been found on Coleoptera and Diptera. Coleoptera is by far the most important order, with at least 43 known host families. However, Diptera may be more important than present knowledge suggests, Coleoptera have been studied and collected to a far greater extent than Diptera. Ants (Formicidae) are the only known hymenopteran hosts and only one host species is known in Thysanoptera; in the other groups the hosts are scattered among many fimilies or genera. Within Acari only the suborder Gamasida (Mesostigmata; see classification in Krantz 1978) contain hosts of Laboulbeniales, most of which are associated with insects. At least two orders with several genera are known as hosts among the millipedes (Rossi \& Balazuc 1977).

The known hosts represent a broad spectrum of ecological adaptations, including aquatic, semiaquatic, terrestrial, subterranean, cavernicolous, phytophagous, predacious, saprophagous, parasitic, marine, limnic, etc. arthropods. Yet, predacious insects are in the clear majority (e.t. Carabidae and Staphylinidae in Coleoptera) and moist conditions are more favourable than dry environments.

\subsection{Host specificity}

Like most parasites, the Laboulbeniales show a high degree of host specificity. A large number of the species occur on only one or a few host species, and very few of them occur on a large number of hosts. This is illustrated in Fig. 2. The specificity is somewhat obs-

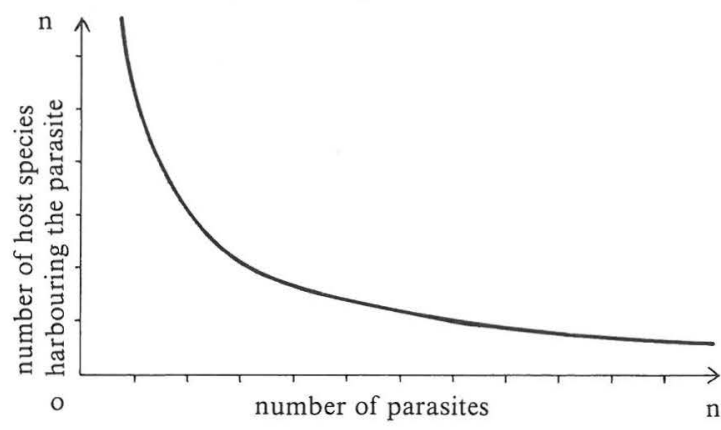

Fig. 2. Schematic presentation of the number of host species

cured by the fact that fungi have both main hosts and accidental hosts. The accidental hosts normally belong to the same genus as the main host but sometimes they may represent different genera, families or even orders and classes (see Benjamin 1971 for examples). The reason for the occurrence on accidental hosts is that the niches of these hosts largely overlap with that of the main host. The persistence of the parasite on an accidental host is usually limited by several factors, unsuitable physiological properties of the host, lack of overlapping between successive ge- nerations of the host, etc. However, accidental transmission to unrelated hosts probably played an important role in the evolution of new taxa (Benja$\min 1967,1968$ b). A case in which entirely unrelated hosts harboured the same parasite was described by Blum (1924): the same species of Laboulbenia occurred on an ant, two genera of parasitic mites and a beetle living in the ant's nest. Similar observations were made by Thaxter (1924). Benjamin (1965) attributed the phenomenon to similarity in properties resulting from long and intimate association.

\subsection{Position specificity}

It has long been known that species of the Laboulbeniales may occupy a very definite position on their hosts (see Figs. 101, 102, 103 and 108). In most cases this must be caused by the host's own behaviour. Scheloske (1976a, 1976b) described two cases of position specificity in which the fungus occurred in different positions on the different sexes of the host, due to their mating behaviour. In both cases different morphs of the fungi inhabited different sexes of the host. This suggests that the sex-of-host specificity originally described by Benjamin and Shanor (1952) and discussed by Benjamin (1971) may not actually exist, the authors merely having observed different morphs of the same parasite. In cases where the fungus occurs in the same position, often asymmetrically, on both sexes of the host (Figs. 101 and 103) the explanation is probably not the mating behaviour but some other kind of behaviour, e.g. cleaning.

\subsection{Distribution of the Laboulbeniales}

The distribution of laboulbeniaceous parasites is determined by the distribution of their main hosts. On the whole the environmental factors may be assumed to be suitable for the parasite if they are suitable for the host, because the parasite seems to thrive only when the host thrives. Many species are known to have very wide distribution and evidently occur wherever a suitable host is present. Species like Laboulbenia vulgaris and Monoicomyces sanctae-helenae are probably cosmopolitan, because their host range is broad, including several genera. Dichomyces furcifer on Philonthus spp. and Stigmatomyces baeri on Musca domestica are also cosmopolitan, having cosmopolitan hosts. Dichomyces nigrescens, occurring only on Philonthus debilis, is holarctic in distribution, like its host. Another distribution pattern is represented by the species pair Asaphomyces cholevae and A. tubanticus; the former is nearctic and the latter European (or palaearctic?). A. cholevae occurs on the holarctic Sciodrepoides fumatus while A. tubanticus mainly occurs on $S$. watsoni and the genus Catops, which also occurs in North America. Thus the two parasites seem to replace each other despite the of common hosts in the two regions, though their records are too scattered to allow definite conclusions.

Yet it is probable that external factors have an direct or indirect influence on the occurrence of the parasite. In colder regions a switch in the life-cycle of the host may make conditions impossible for the par- 
asite. Siemaszko \& Siemaszko (1928) reported that Laboulbenia vulgaris reached only $1000 \mathrm{~m}$ in the mountains and that L.alpestris known to occur high in the Alps in Switzerland and France, occurred only in the lowlands in Poland. Similarly the lack of many species in northern Finland must be caused at least indirectly by external factors, as their hosts may occur throughout the country (for discussion see section 7.4.).

\section{Systematic position}

Despite the great diversity in the habit of the thallus, the Laboulbeniales are a well-defined group of fungi, whose members are fairly easy to recognize. The exceptional morphology of the ascospore is considered to be important evidence that the Laboulbeniales are monophyletic (Benjamin 1973). Other features common to all members are the lack of vegetative mycelia, blackened foot, more or less determinate growth pattern of the thallus and obligate parasitism on arthropods.

The first members of the Laboulbeniales described in the 19th century were placed with some hesitation among the Ascomycetes. Thaxter (1896) was the first to describe the ascogenous system and to demonstrate the affinities to the Ascomycetes. However, the Laboulbeniales long remained a 'wild' group within Ascomycetes. The nonmycelial thallus with its determinate growth pattern keeps the Laboulbeniales apart from the class and suggest the status of subclass.

Cavaliere \& Johnson (1965) described a new parasitic fungus of unknown systematic position, Spathulospora phycophila, occurring on a red alga, Ballia callitricha Ag., in the southern hemisphere. Four additional species of Spathulospora were described by Kohlmeyer (1973), who placed the fungi in a separate order, the Spathulosporales. He considered the new order to be a missing link between the Laboulbeniales and the pyromycetial Ascomycetes. There are many similarities between the Laboulbeniales and the Spathulosporales, the main difference being that the spores in the former group are two-celled whereas in the latter group they are one-celled.

Kohlmeyer (1975) reviewed the evidence for the old hypothesis that the Ascomycetes originate from red algae (Rhodophyta). Savile (1968) had suggest that 'the first typical fungi were probably parasites; and it was as parasites that the fungi left the water...' Agreeing with this view, Kohlmeyer considered the Spathulosporales to be an archaic group of fungi with many primitive characteristics, such as thin-walled, early deliquescent asci, presence of antheridia and a trichogyne and lack of asexual spores. Obligate parasitism is also considered to be a more primitive feature than the saprophytic habit. Corresponding characteristics are found in the Laboulbeniales. It is assumed that the Ascomycetes evolved from ancestors related to fungus-like parasitic red algae. The Spathulosporales and the Laboulbeniales probably separated very early from the main line of Ascomycetes and preserved their obligate parasitic habit. The Laboulbeniales must be considered a highly specialized line, while the
Spathulosporales probably represent a more primitive form.

In a very recent classification (Eriksson 1982) the Ascomycetes are divided into two subclasses, Euascomycetidae and Laboulbeniomycetidae, the former comprising 37 orders and the latter the two orders Laboulbeniales and Spathulosporales.

In this connection it is worth mentioning that no fossil representatives of the Laboulbeniales have yet been found, despite the large number of insects in good condition known from amber in different parts of the world. Hitherto only one record of Entomophthorales (a group of endoparasitic fungi) and a few saprophytic fungi have been obtained from insects in amber (Larsson 1978, Poinar \& Thomas 1982). The lack of fossil records is probably due to the fact that entomologists are not generally acquainted with fungi ectoparasitic on insects.

\section{Classification of the Laboulbeniales}

In his monographs $\mathrm{R}$. Thaxter recognized three major groups in the Laboulbeniales, nowadays treated as families, viz. the Laboulbeniaceae, Peyritschiellaceae and Ceratomycetaceae. This classification was primarily based on the structure of the male sexual organs, in which three types were distinguished: simple antheridia, compound antheridia and exogenous spermatia. The main shortcoming of this system is that in many genera the male sexual organs are still unknown. Tavares $(1980,1981 b)$ recently described or validated two new families, the Herpomycetaceae and the Euceratomycetaceae, using the development of the perithecium and origin of the female sexual organ as the basic characters. She had previously (Tavares 1967) suggested the ontogeny of the perithecium as a new basis four classification. However, no classification has yet been elaborated that comprises all the described genera and takes into consideration all the recent advances in this group. Tavares (1981b) and Eriksson (1982) outline the division of the Laboulbeniales as follows:

Order Laboulbeniales

1. Suborder Herpomycetinae

1. Family Herpomycetaceae

2. Suborder Laboulbeniinae

1. Family Laboulbeniaceae

2. Family Peyritschiellaceae

3. Family Ceratomycetaceae

4. Family Euceratomycetaceae

The order contains 130 genera (Rossi \& Balazuc 1977, Tavares 1979, Majewski 1980, Terada 1981, Rossi 1982). This number includes the unnamed segregates of described genera noted by Tavares (1979).

\section{Laboulbeniales-like parasites and hyperparasites}

Most of the known ectoparasitic fungi on arthropods belong to the Laboulbeniales. There is, however, a small heterogenous group of ectoparasites for which only an anamorph is known and which have been 

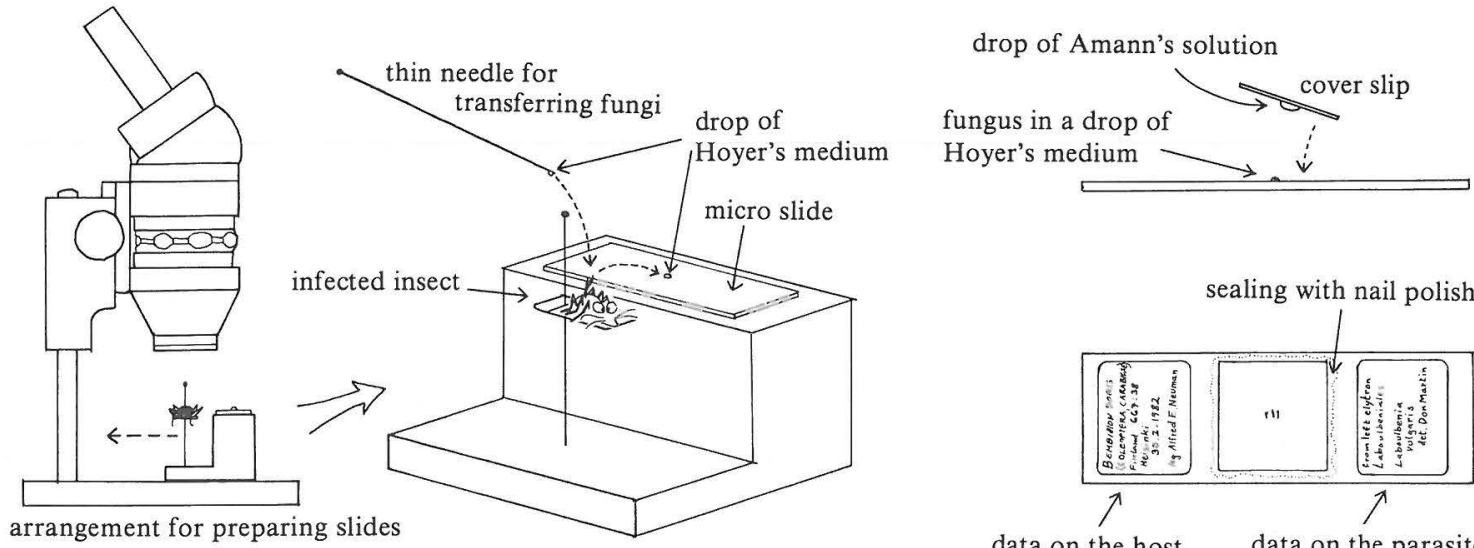

Fig. 3. Preparation of the slides

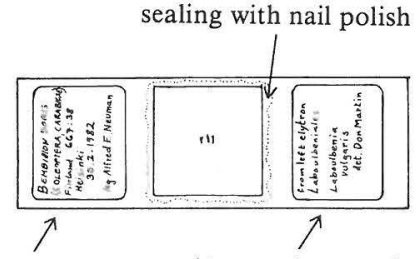

data on the host data on the parasite

placed in the Deuteromycetes. A large number of these nonperithecial ectoparasites were described early in this century (Thaxter 1914, 1920, Spegazzini 1918, Siemaszko \& Siemaszko 1928). In recent years the taxonomy of this group of fungi has received more attention (Buchli 1966, K'han \& Kimbrough 1974, Balazy \& Wisniewski 1974, Majewski \& Wisniewski 1978, Blackwell \& Kimbrough 1978, Kimbrough \& Lenz 1982). Some of them are amazingly similar to the Laboulbeniales. They may have a blackened foot and consist of one, two, three or more cells with a more or less characteristic growth pattern. As long as affinities to the Laboulbeniales have not been confirmed, Madelin (1968) prefers to consider them remarkable instances of parallel evolution. Within the group some genera have specialized on certain groups of arthropods, e.g. Antennopsis on termites, Aegeritella on ants and Thaxteriola and Acariniola on mites.

The nonperithecial genus Amphoromorpha, which normally occurs as an ectoparasite on insects, has sometimes been found as a hyperparasite on members of the Laboulbeniales (Siemaszko \& Siemaszko 1928, Rossi \& Cesari Rossi 1979b, see also section 8.4. and Figs, 99 and 100). Cepede (1913) described a hyperparasite, Fusarium laboulbeniae, on Laboulbenia casnoniae Thaxter (L. blanchardi Cepede), and Rossi (1978) reported a hyperparasite, possibly related to Monilia, on a species of Rickia (Laboulbeniales). The Laboulbeniales are so rare as a resource that their hyperparasites may be assumed to be quite unspecialized fungi.

\section{Laboulbeniales in Finland and adjacent parts of the U.S.S.R.}

\subsection{Material and methods}

Most of the fungus material was obtained from the collections of the Division of Entomology, Zoological Museum, University of Helsinki (MZH). Some additional material was found in the collections of the Department of Agricultural and Forest Zoology of the University of Helsinki, Tvärminne Zoological Station, the University Oulu and some private collec- tions. Lastly, some species have been recorded during field work by the author in the years 1979-1982. Most of the insect families known as potential host and a smaller number of millipedes were studied (see Appendix 1). More than 160000 specimens of insects, representing about 1100 species, were examined with a dissecting microscope (up to $\times 100$ magnification). The determinations of most of the infested specimens of Coleoptera were checked by the author, within Diptera he had to rely on previous determinations, but many of these were made by specialists. The fungus slides were mainly mounted by the method described by Benjamin (1971). The following two media were used:

\section{Amann's solution}

$\begin{array}{lc}\text { Phenol } & 20 \mathrm{~g} \\ \text { Lactic acid } & 16 \mathrm{~g} \\ \text { Glycerol } & 32 \mathrm{~g} \\ \text { Distilled water } & 20 \mathrm{ml} \\ \text { Acid fuchsin } & 0.1 \mathrm{~g} \\ & \\ & \\ \text { Gr's medium } & 30 \mathrm{~g} \\ \text { Gum arabic } & 200 \mathrm{~g} \\ \text { Chloral hydrate } & 16 \mathrm{~g} \\ \text { Glycerol } & 50 \mathrm{ml} \\ \text { Distilled water } & \end{array}$

(Note: The components of Hoyer's medium dissolve very slowly, requiring $2-3$ days). The fungi were removed from the insects with a very thin needle with a drop of Hoyer's medium, placed in a small drop of the same medium on a micro slide and covered with a square cover slip with a drop of Amann's solution. The cover slip was sealed with nail polish. After a week in medium the dry fungi had regained their normal size and shape. Data on the host were written on the slides. The illustrations of the fungi were made by means of a drawing tube connected to a research microscope. The infested insects were drawn by free hand. The whole preparation of the slides can most easily be performed under the dissecting microscope, the infested insect and the micro slide being placed close together and on the same level, Fig. 3.

All the fungus material (including types) and the infested host insects are deposited in a separate collection in $\mathrm{MZH}$. 


\subsection{The study area}

The study area was chosen in accordance with the East Fennoscandian collection in the Zoological Museum of the University of Helsinki. The area comprises Finland, the northern part of the Leningrad Region, the Karelian A.S.S.R. and the Murmansk Region. Records from the Solovetsk Islands, belonging to the Archangel Region, have also been included (see Fig. 4).

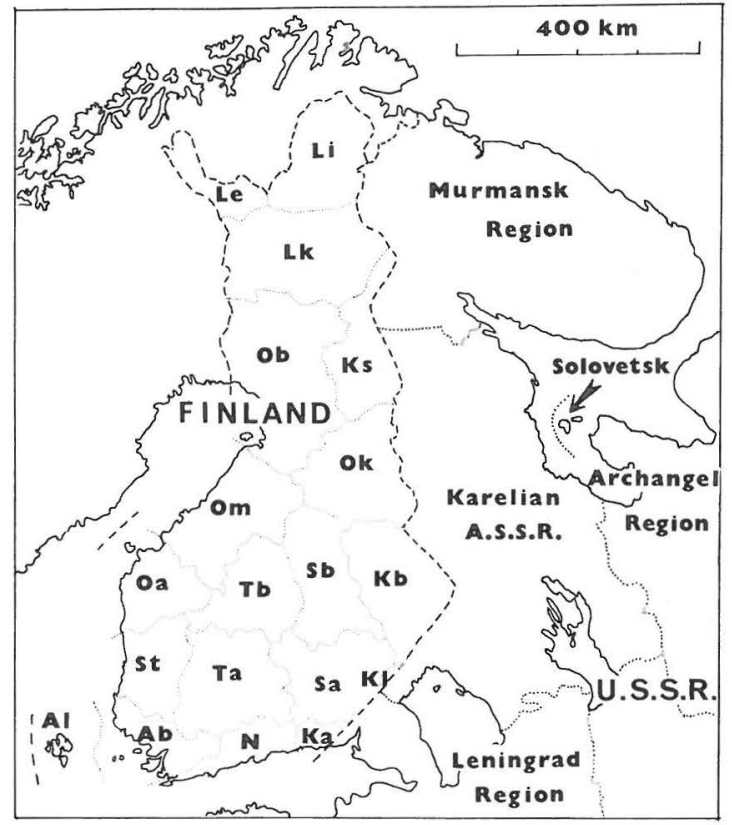

Fig. 4. Study area. Finland divided in biogeographic provinces.

\subsection{Species composition and host range}

The taxa of Laboulbeniales number 88 and represent 27 genera. Twenty-three species and one subspecies are described as new and four American and one East Asian species are recorded for the first time from Europe. By far the most important genera are $\mathrm{La}$ boulbenia and Stigmatomyces, with 27 and 14 species, respectively. Nineteen genera are represented by only one species (Appendix 3).

Only Coleoptera and Diptera were found to be infected by Laboulbeniales in Eastern Fennoscandia. The Coleoptera specimens represent 15 families, 52 genera and 149 species. The most important families are the Carabidae (64 species), Staphylinidae (50 species), Gyrinidae (8 species) and Catopidae (8 species). The Diptera specimens represent 4 families, 11 genera and 18 species, the most important family being the Ephydridae, with 12 species. Diptera seems to be a poorly studied order, as 10 of the 14 parasite species found in this group have to be described as new. The museum material of Diptera is very poor in comparison with that of Coleoptera.

In Appendix 2 all the recorded parasites are listed under their host species. The host species are arranged in systematic order according to Silfverberg (1979) and Hackman (1980).

\subsection{Frequency on the host and distributional patterns}

As the insects in the museum (and most other collections) in general are collected at random with respect to the occurrence of the Laboulbeniales (because of the parasites' minute size and harmlessnes to their host), the number of infected specimens (regardless of the number of parasite species) in relation to the total number of specimens can be taken as a measure of the frequency of Laboulbeniales on their hosts in a given area, here Eastern Fennoscandia. The insect collections in $\mathrm{MZH}$ are representative with respect to the distributions of the insects in Eastern Fennoscandia and thus the frequency values must be interpreted in a general sence and not at the level of single host population. The values are largely comparable with those given by Scheloske (1969) from Central Europe (Federal Republic of Germany: Bavaria), although derived from an area of different size. Scheloske's values are given in Appendix 2 in all cases where the host taxa appear in both lists.

It is remarkable that the frequency of Laboulbeniales in Central Europe is generally 10 to 30 times as high as in Northern Europe. In only four host species in Northern Europe did the frequency exceed $10 \%$ (only cases with $\geqq 50$ host specimens considered), while the corresponding number of host species in Central Europe was 35. At the host family level, the frequencies in Northern Europe are generally about $1 \%$, but in Central Europe 10-33\%. The trend is evident regardless of the taxonomic level. This is probably chiefly due to the changing conditions in the host populations in the north, smaller and/or more isolated populations, high winter mortality, narrow or variable overlapping of successive generations (caused by less predictable climatological conditions), partially changed life-cycle patterns, etc. For a few host species the frequency of parasites in the north exceeded that in Central Europe, e.g. Philonthus debilis and Quedius fuliginosus. The material in such cases is possibly too small for any definite conclusions.

When the separate parasite species are considered, it must be kept in mind that the individual host species are not equally common all over their distributional area. An oligophagous parasite probably prefers the most common (or suitable) of its potential host species in a particular area. In interpreting the frequencies of the separate parasites, attention must be paid to the circumstances of the individual cases.

The distribution of the species of Laboulbeniales occurring in Eastern Fennoscandia are given in Figs. 114-201 according to the 50-km UTM grid (cf. Atlas Florae Europaeae). Fig. 204 shows the numbers of species in six latitudinal zones $(200 \mathrm{~km}$ in width, except zone I, which comprises the archipelago of Âland, and zone VI, which is $400 \mathrm{~km}$ wide). The decrease in the number of parasite species towards the north is only partly due to the decrease in the number of known host species, see Table 1. 
Table 1. The number of parasite and host species in the different zones of East Fennoscandia.

$\begin{array}{cc}\text { Number of } & \text { Number of } \\ \text { parasite species } & \text { host species }\end{array}$

$\begin{array}{llr}\text { Zone I } & 34 & 110 \\ \text { Zone II } & 66 & 141 \\ \text { Zone III } & 40 & 127 \\ \text { Zone IV } & 19 & 109 \\ \text { Zone V } & 17 & 97 \\ \text { Zone VI } & 19 & 74\end{array}$

The number of parasite species decreases to one quarter in the north, while the number of host species decreases to only about one half of that in the south of Finland. The difference is somewhat exaggerated because the number of host species includes accidental hosts. However, it is evident that many parasite species do not reach the northernmost areas of their hosts, although in some cases lack of parasites may depend on incomplete collecting of the hosts. The parasites are also underrepresented in the archipelago of Aland in comparison with the number of existing host species. Probably some degree of isolation of the host populations on these islands explains the paucity of parasite species.

Very few if any of the parasites are exclusively northern in distribution. Some of the taxa described as new here cannot be considered in this respect (i.e. Dichomyces furcifer ssp. subarcticus, Laboulbenia murmanica or L. hastiana), because their records are too limited. Rickia hyperborea which inhabits Micralymma species on the shores of the Arctic Ocean has also been recorded from France, on the Atlantic coast (Balazuc 1980). If there are any arctic or northern species of Laboulbeniales they are certainly specialists (probably monophagous), because generalists always seem to have potential hosts in many regions.

Finally, two examples of curious distribution patterns ought to be mentioned:

a) Both Laboulbenia vulgaris and Haplomyces texanus have disjunct distributions, with many records in the south and the north but none in the central part of the study area. In both cases the parasite occurs on different hosts in the separate ranges, which may possibly explain these distributions.

b) Laboulbenia pedicellata and Misgomyces dyschirii. The main host of these species in Northern Europe seems to be Dyschirius globosus (distribution of checked specimens given in Fig. 169), which is common all over Eastern Fennoscandia. L. pedicellata reaches the southern border of zone VI, which presumably indicates the limit of suitable conditions for the Laboulbeniales on $D$. globosus, but $M$. dyschirii is restricted to the south. It is possible that some climatological factors directly limit the distribution of the latter species.

\subsection{Population dynamics of Laboulbenia fennica in Finland}

Laboulbenia fennica is a southern species in Finland (Fig. 150) although at least three of its known hosts (Gyrinus aeratus, G. minutus and G. marinus) are dis- tributed throughout the country (Huldén 1983). The main host seems to be Gyrinus aeratus, which normally forms large and dense populations on the surface of medium-sized to large streams. L. fennica is known from both lentic and lotic habitats but records in lentic habitats and on hosts other than G. aeratus (and possibly G. minutus and G. marinus) seem to be only accidental. Investigations in several permanent localities of $L$. fennica have yielded some interesting preliminary results. The frequency of the parasite in a host population (\% of infected specimens) seems to be fairly constant from year to year but may differ from one host population to another. In the more thoroughly studied cases the frequencies were found to be 95$100 \%$ in two localities (four generations), about $50 \%$ in a third locality (three generations) and 30 $50 \%$ in a fourth (two generations). The host overwinters in the imaginal stage and mates in May, the new generation reaching the imaginal stage in late June and July. Samples of the host have shown no seasonal variation in the frequencies of the parasite, indicating that the new generation is immediately infected by the overwintered generation. The variation in the extent to which the different host populations are parasitized is interesting. If there are no significant differences in the properties of the spores, it must be due either to the host and/or to external factors. Clusters of Gyrinids are usually composed of several species, one dominant species and a few other species in variable portions. Some species, such as $G$. natator and $G$. substriatus, are rarely infected. When $G$. minutus or $G$. marinus are present in clusters of $G$. aeratus, all the species are infected to the same degree by Laboulbenia fennica. This suggests that the variation in parasitization cannot be due to differences in resistance in the hosts, because it is unlikely that resistance would differ between localities in the same way in different species of Gyrinus. The reason for the variation probably lies in external factors. Differences in the vegetation density, speed of current, food resources, etc. may cause variation in the distance between host individuals, thus affecting the probability of the spores reaching new hosts. The spores are presumably spread along the surface of the water.

Scheloske (1969, Figs. 5 and 6) described two different patterns of population dynamics in the Laboulbeniales, which depended on the hosts' life cycles. In the first case the host is a spring-breeding species (Oxytelus rugosus infected by Peyritschiella protea), in which the old generation dies during the summer after the new generation has reached the imaginal stage. The imaginal stages of the two generations overlap in the latter part of the summer and the new generation has not time to become heavily parasitized before overwintering, but in the following spring and summer the frequency of the parasite rapidly increases. In the second case the host is an autumn-breeding species (Patrobus atrorufus infected by Laboulbenia fasciculata), which overwinters in the larval and imaginal stages. The old generation partially survives a second winter and dies after the new generation has reached the imaginal stage in early summer. In this host the frequency of the fungus is lowest in mid summer after the appearance of the new host generation but, gra- 
dually rises to its maximum before the winter, then remaining stable till the next summer.

Laboulbenia fennica, which occurs on a springbreeding host, presents a third pattern of population dynamics. The infection frequency of the host is constant, because the new generation is immediately infected to a certain ( \pm high) definite level. Immediate transmission of the spores to new host individuals is necessitated by the continuous movement of the water (also in backwaters), otherwise the spores will be lost. The two patterns described by Scheloske were found in predacious insects living on land, where the time needed for the infection of the new generation is prolonged by the relatively low activity and density of the host (compared with Gyrinus species). The three patterns are illustrated in Figs. 5 a-c.
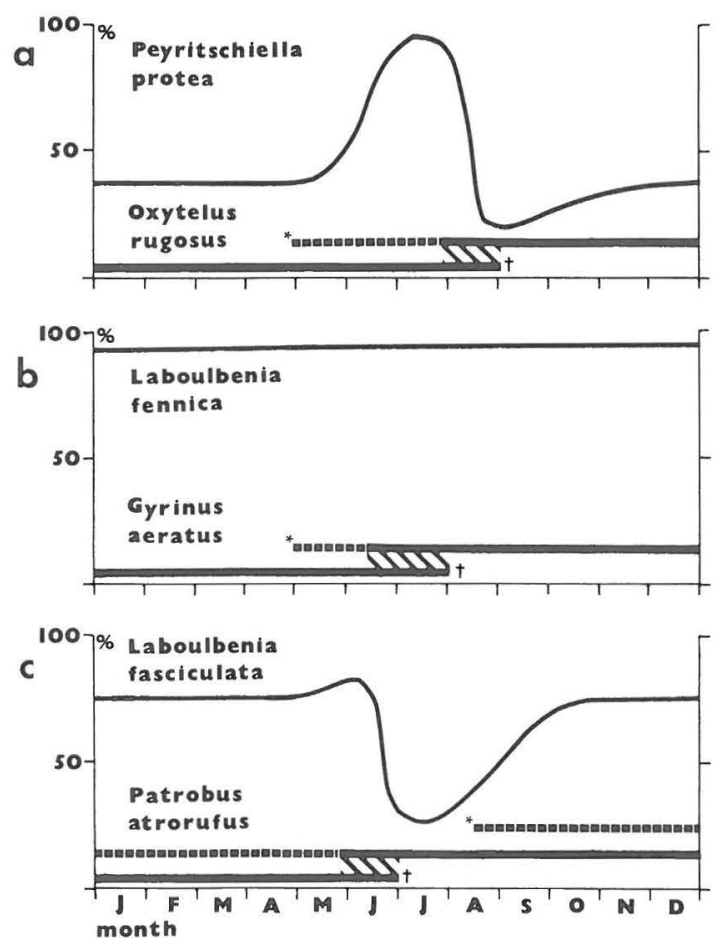

- frequency of the parasite in the host population

preimaginal stages of the host

- imaginal stage of the host

IMI overlapping of the host generations (imaginal stage)

Fig. 5. Life-cycle patterns of three laboulbeniaceous parasite species. a) Peyritschiella protea on Oxytelus rugosus, b) Laboulbenia fennica on Gyrinus aeratus, c) Laboulbenia fasciculata on Patrobus atrorufus. a) and c) modified from Scheloske (1969).

The following general conclusions can be made: (1) The level of infection during overwintering of the host is determined by the time at which the host generations overlap. The earlier the overlapping period, the higher the level of infection during overwintering. It is possible that the general shape of the infection curve in a spring-breeding species (Fig. 5a) may resemble that in an autumn-breeding species (Fig. 5c) if the pre-imaginal development is rapid. (2) The speed with which the parasite spreads within the new host generation depends on the activity of the host and may possibly be altered by climatological factors. In the case of highly specialized transmission patterns there is little seasonal variation in the frequency of the parasites. (3) The upper level of frequency is mainly determined by the suitability of the habitat of the host and partially by climatological factors.

These conclusions are probably generally valid for univoltine host species in temperate regions. The paucity of parasite species in the north indicates changes in the life-cycle patterns and population dynamics of the hosts, chiefly due to the decreasing temperature.

\subsection{Potential new parasite species in Finland}

Despite the large insect material that has been checked, it is obvious that many new laboulbeniaceous parasite species are still to be found in the study area. The interested student should consult the parasitehost list given by Stadelmann \& Poelt (1962), which comprises Central European species. The coleopteran families Carabidae and Staphylinidae are well studied groups, but many families of aquatic and semi-aquatic beetles are still imperfectly studied. More attention should also be paid to Diptera (e.g. Drosophilidae, Empididae, Sphaeroceridae and Ephydridae), aquatic Heteroptera (Hebridae and Corixidae), Mallophaga, Blattodea (mainly introduced species), Dermaptera and Hymenoptera (Formicidae). Examples of parasite species which should be searched for in Finland are:

- Rickia wassmannii Cavara, on Myrmica spp. (Hymenoptera, Formicidae),

- Coreomyces spp., on genera of Cymatia, Callicori$x a$, Hesperocorixa and Sigara (Heteroptera, Corixidae),

- Tavaresiella hebri Majewski and Triceromyces balazucii Majewski, on Hebrus ruficeps Thomson and $H$. pusillus (Fallén) (Heteroptera, Hebridae),

- Hesperomyces forficulae Majewski, on Forficula auricularia Linnaeus (Dermaptera, Forficulidae), - Laboulbenia cristata Thaxter, on Paederus spp. (Coleoptera, Staphylinidae),

- L. harpali Thaxter, on Harpalus spp. (Coleoptera, Carabidae),

- Stigmatomyces entomophilus Thaxter, on Drosophila funebris (Fabricius) (Diptera, Drosophilidae).

In addition to the insects also mites and millipedes ought to be more extensively studied.

\section{Taxonomic section}

\subsection{Terminology}

The terminology used is chiefly that of R. Thaxter in his monographs. Laboulbenia vulgaris is often used as a basis in naming the essential structures and numbering cells. In Laboulbenia the receptacle is typically five-celled and these cells are numbered I-V. Cell I is 
inner appendage
(bearing antheridia)

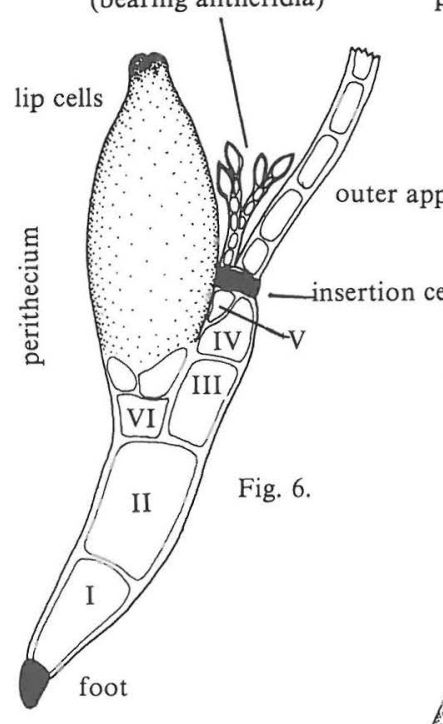

Fig. 7

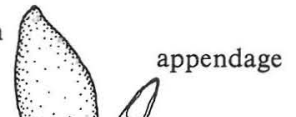

Figs. 6-10. Schematic illustrations of -6 : Laboulbenia sp. - 7: Siemaszkoa sp. - 8: Monoicomyces sp. - 9: Stigmatomyces $\mathrm{sp}$. and - 10: Dichomyces sp.

the basal cell and cell II the subbasal cell of the receptacle. Cell VI is the stalk cell of the perithecium. The more or less black insertion cell is mainly limited to Laboulbenia (see Fig. 6).

Cell IV and V are differentiated only in Laboulbenia. In some other genera, such as Misgomyces and Siemaszkoa, cells I and II may form a long stalk by secondary divisions and then only cells III and IV are distinctly defined (see Fig. 7).

In most genera the (primary) appendage grows from cell II. In Monoicomyces the receptacle consists of a primary axis (cells I-II + appendage) and one or several secondary axes arising laterally from cell II and bearing appendage, antheridia and perithecia (see Fig. 8).

In the perithecium of Stigmatomyces three sections are recognized: the basal venter, the neck and the distal tip (Fig. 9). The lip cells constituting the tip may possess processes important for the identification of the species.

In Dichomyces (Fig. 10) the receptacle is bilaterally symmetric and consists of one single basal cell and three superposed transverse rows of cells. The lowest row forms lateral, more or less blackish projections, the second row bears compound antheridia and sterile appendages and the distal third row bears perithecia and sterile appendages.

In most genera the margin on the appendage side of the perithecium is interpreted as the inner (anterior) margin, and that on the opposite side as the outer (posterior) margin. The orientation may sometimes be obscured by spiral rotation of the rows of wall cells.
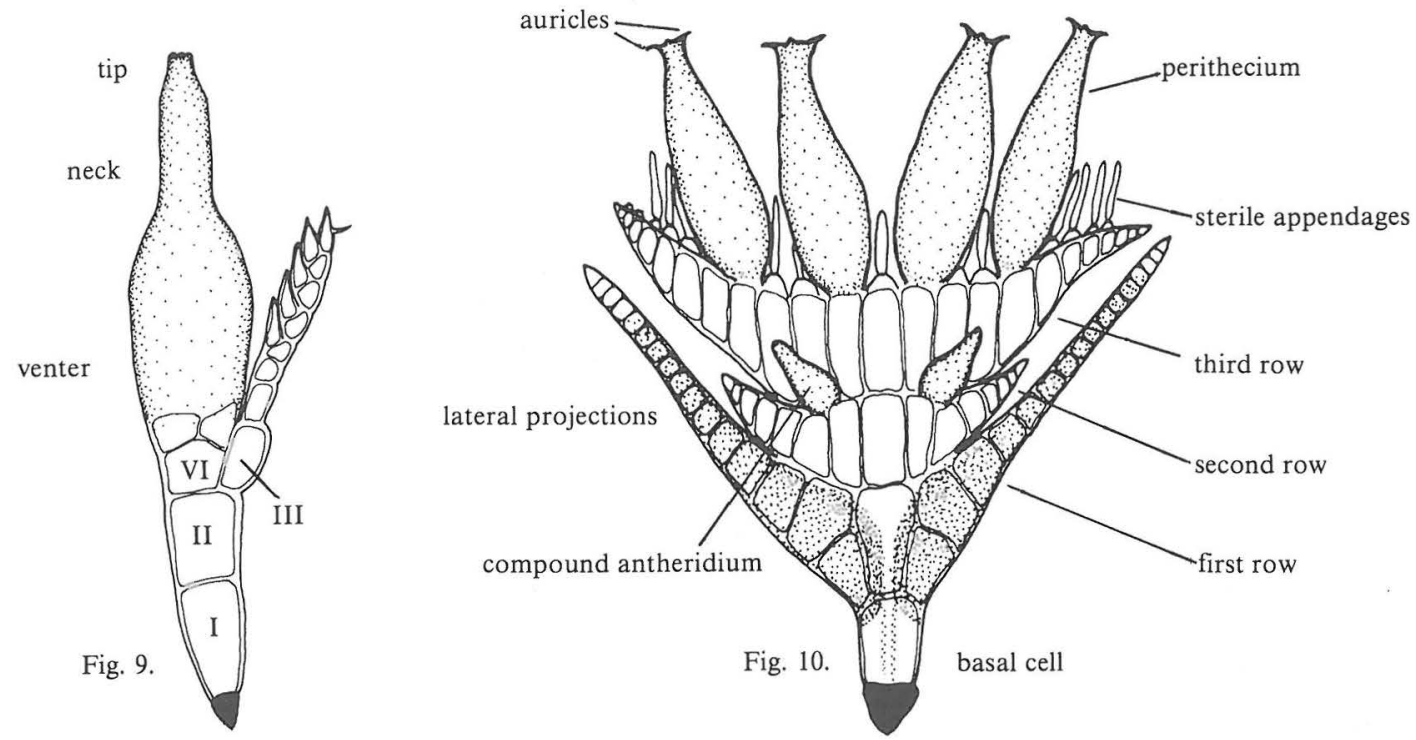


\subsection{Identification of the species of Laboulbeniales}

Although the species of Laboulbeniales are morphologically separable it is almost impossible to construct a traditional key on this basis. Benjamin (1971) published a key to the genera, but even at this level a key is very difficult to use for beginners. The easiest way to identify the parasites is first to determine the host and then to find out which parasites are known from that host. Usually only a few parasite species need be considered. The parasites of related hosts should also be checked. In many cases the parasites in question belong to different genera and are consequently immediately recognized. In other cases serious problems may arise, especially with genera like Laboulbenia. Descriptions and illustrations of material from different areas must be carefully examined, but even then the identification may be no more than tentative. The reason may be that the genus is in a state of strong speciation and that the separate taxa are still not properly established. Separate species may occur in many distinct host strains.

\subsubsection{Key to the genera of the East Fennoscandian Laboulbeniales}

The following key to the genera found in the study area is modified from Benjamin (1971) and includes some additions from Tavares (1979). Unfortunately it is rather theoretical, but at least it indicates the characters that deserve closest study. It can most conveniently be compared with the illustrations, because the genera are often immediately recognized by their general habitus. However, it must be kept in mind that members of additional or even undescribed genera can still be expected to be found. Students of the group are also referred to the generic key in Benjamin (1971).

1 Perithecium, together with its true stalk and basal cells borne on a stalk of two small cells. Receptacle consisting of an indeterminate number of superposed cells generating an elongate, massive multicellular axis continous with a terminal branched appendage and laterally bearing numerous perithecia and appendages. On Lathrobium (Col., Staphylinidae) ............. Euzodiomyces

- Perithecium, together with its true stalk and basal cells, sessile or, if appearing stalked, the stalk consisting of the true stalk cell and one or more of the modified basal cells of the perithecium

2 Outer wall of perithecium (opposite to the appendage), excluding its basal cells, composed of at least seven or more tiers of wall cells ............................. 3

- Outer wall of perithecium, excluding its basal cells, composed of only four or five tiers of wall cells ...... 4

3 Receptacle consisting of a large number of superposed cells. On Dryops (Col., Dryopidae) ...... Helodiomyces

- Receptacle consisting of three or four superposed cells. On Haliplus (Col., Haliplidae) ......... Hydraeomyces

4 Dioecious. Male individual consisting of only four superposed cells, the fourth being one simple antheridium, much smaller than the female individual (Figs. $33 \mathrm{a}-\mathrm{i}$ ). On Anthicus (Col., Anthicidae) ........... Dioicomyces

- Monoecious. Antheridia normally occurring on the appendage, but in some genera unknown .............

5 Antheridia simple, borne singly or in groups .......... 6

- Antheridia compound, well-defined, consisting of few to many antheridial cells ......................... 21
6 Receptacle with only two cells subtending the stalk cell of a single primary perithecium and the stalk cell of the appendage, the subbasal cell of the receptacle not giving rise to secondary fertile or sterile axes or branches ... 7

- Receptacle with more than two cells subtending the stalk cell of the primary perithecium and/or the appendage; if the receptacle apparently two-called and bearing a primary perithecium and primary appendage, then subbasal cell forming secondary fertile axes or secondary fertile or sterile appendages ........................ 11

7 Subbasal cell of the receptacle and stalk cell of the perithecium laterally adnate. On Ptomaphagus (Col., Catopidae), unpublished segregate of Corethromyces (Tavares pers.comm.), ................................ C. niger

- Subbasal cell of the receptacle and the stalk cell of the perithecium superposed $\ldots \ldots \ldots \ldots \ldots \ldots \ldots \ldots \ldots . \ldots$

8 Basal cell + subbasal cell of the receptacle constituting a quarter or less of the length of the whole thallus ..... 9

- Basal cell + subbasal cell of the receptacle usually much more developed, constituting a third to a half of the length of the whole thallus ........................ 10

9 The appendage well developed and strongly branched. On Choleva (Col., Catopidae) .......... Corethromyces

- The appendage well developed (but fragile), unbranched. On Brachygluta (Col., Pselaphidae)

Peyerimhoffiella

- The appendage poorly developed with only two or three slender branchlets. On Cryptophagus (Col., Cryptophagidae) ............................. Autophagomyces

10 The appendage consisting of a main axis with lateral antheridia in one or two rows. On Diptera - The appendage sympodially branched. On Copromyza (Dipt., Sphaeroceridae) .................. Fanniomyces

11 Receptacle composed of a more or less indeterminate number of cells, these disposed in a single vertical series, or by secondary divisions, forming superposed tiers of cells, each tier containing a definite or indefinite number of cells

- Receptacle composed of two to four or rarely more superposed cells, these not forming superposed tiers of cells

12 Receptacle consisting of an indeterminate number of superposed cells, which, by transverse divisions in the upper part of the receptacle, form irregular tiers containing an indefinite number of cells. On Cyrtusa (Col., Leiodidae) ......... see Ecteinomyces agathidii for comments.

- Receptacle consisting of an indeterminate number of cells superposed in a single series; these cells remaining undivided or giving rise to single appendiculate cells on one side

13 Axis of the receptacle with appendages forming belc well as above the point of insertion of the perithecium. On Staphylinidae (Col.) ................. Rhachomyces

- Axis of the receptacle not giving rise to appendages below the point of insertion of the perithecium ........ 14

14 Outer, basal wall cells of the perithecium with an interposed, elongate, externally prominent accessory cell extending from the basal cell region to the subbasal tier of wall cells. On Ochthebius (Col., Hydraenidae) ............ Hydrophilomyces

- Basal tier of wall cells of the perithecium without an interposed accessory cell ....................... 15

15 Walls of basal cells of perithecium distinct, equal number of cells in each vertical row of perithecial wall cells. On Acrotrichis (Col., Ptiliidae) ........... Ecteinomyces

- Wall of basal cells of perithecium indistinct, unequal number of cells in different vertical rows of perithecial wall cells. On Ptenidium (Col., Ptiliidae)

Siemaszkoa

16 Subbasal cell of the receptacle followed immediately above by two cells placed side by side ............ 17 
- Subbasal cell of the receptacle forming secondary cellular axes or fertile branches or simply followed by a continuation of the primary axis ...................... 18

17 Appendages terminating the upper one or two cells of the receptacle simple, unbranched, unicellular, evanescent, distinguished at the base by small constricted, darkened septa; antheridia unknown. On Dytiscidae (Col.)

Chitonomyces

- Appendages more or less well developed, simple or branched, usually bearing simple antheridia. On Carabidae and Staphylinidae (Col.) ............ Laboulbenia

18 Receptacle consisting of a small, but indeterminate number of superposed cells directly continuous above with a more or less elongate sterile or fertile appendage. One to three perithecia arising laterally from successive proximal cells of receptacle. On Catops and Sciodrepoides (Col., Catopidae) .................... Asaphomyces

- Receptacle consisting of three or four superposed cells readily distinguishable from terminal part ......... 19

19 Receptacle terminated by three cells; the single posterior cell bearing a terminal primary appendage; the two anterior cells each bearing a single primary perithecium, a simple antheridial appendage, and an elongate cellular axis, each cell of which bears a branched antheridial appendage; cells of the fertile branches converted directly into simple antheridial cells. On Erichsonius (Col., Staphylinidae) ........................... Diplomyces

- Receptacle terminated by numerous small cells bearing appendages, which more or less surround the base of the perithecia

20 Cells of the fertile appendages subtending free, flaskshaped antheridia, which may be associated with sterile, beak-life branchlets. On Erichsonius and Gabrius (Col., Staphylinidae) ......................... Teratomyces

- Cells of the fertile appendages converted directly into simple antheridial cells having short, divergent discharge tubes; beak-like cells present or absent. On Quedius (Col., Staphylinidae)

Symplectromyces

21 Receptacle composed of a long uniseriate row of superposed cells; base of appendage forming a compound antheridium. On Dyschirius (Col., Carabidae)

Misgomyces

- Receptacle composed of two superposed cells or the receptacle leaf-like, due to secondary transverse divisions

22 Receptacle with more than two cells subtending the stalk cell of the primary perithecium and/or the appendage; if the receptacle apparently two-celled and bearing a primary appendage, then the subbasal cell also forming secondary fertile axes

- Receptacle with only two cells subtending the stalk cell of a single primary perithecium and the stalk cell of the appendage; the subbasal cell of the receptacle not giving rise to secondary fertile or sterile cellular axes or branches

23 Receptacle composed of two superposed cells subtending a sterile cellular appendage; the subbasal cell giving rise to one or more secondary fertile axes on one or both sides. On Staphylinidae (Col.) ........... Monoicomyces

- Receptacle composed of four or more superposed cells, above the single basal cell by secondary transverse divisions forming tiers containing a definite or indefinite number of cells ............................... 24

24 Receptacle, above the single basal cell, composed of an indefinite number of cells which, by secondary transverse divisions, form three vertical rows of cells. On Micralymma (Col., Staphylinidae) and Scaphisoma (Col., Scaphidiidae) ............................. Rickia

- Receptacle, above the single basal cell, composed of three superposed cells which, by secondary transverse divisions, form tiers containing an indefinite number of cells
25 Receptacle bilaterally symmetrical; the subterminal tier of cells forming a single compound antheridium on or near the outer margin on each side. On Philonthus (Col., Staphylinidae) ......................... Dichomyces

- Receptacle bilaterally asymmetrical; the subterminal tier of cells forming a single compound antheridium near the outer margin on one side only. On Anotylus (Col., Staphylinidae) .......................... Peyritschiella

26 Appendage forming a sterile branch or branchlets in addition to the compound antheridium. On Staphylinidae and Dryopidae (Col.) ............. Cantharomyces

- Appendage without sterile branch or branchlets .... 27

27 Basal and subbasal cells of receptacle broadly and obliquely superposed, becoming nearly vertically parallel to one another. On Agonum (Col., Carabidae)

Eucantharomyces

- Basal and subbasal cells of receptacle transversely superposed. On Bledius (Col., Staphylinidae)

Haplomyces

\subsubsection{Keys to the species of the East Fennoscandian} Laboulbeniales

Species can be identified on the basis of the host-parasite list given in Appendix 2. In those cases in which many parasite species belonging to the same genus occur on the same host genus, additional instructions are given below. The reader is also referred to the parasite-host lists in Stadelmann and Poelt (1962), Scheloske (1969), Tavares (1979) and Frank (1982).

\section{A. Coleopteran genera \\ Atheta}

1 Stalk of perithecium with brownish constriction ........ .......................... Monoicomyces homalotae

- Stalk of perithecium more evenly broad, pale ..................................... Mritannicus

\section{Bembidion}

1 Septum IV-V more or less vertical, connected with septum III-IV .................. Laboulbenia pedicellata

- Septum IV - V oblique, not connected with septum IIIIV ......................................... 2 or third cell ............................... L. hastiana

- Outer appendage not specially robust, simple or moder-

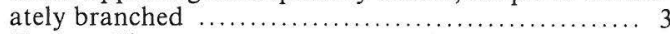

3 Two swellings at upper, outer margin of perithecium

- Without such swellings on perithecium ............... 4

4 Insertion cell at level of base of perithecium, appendages poorly developed with slender branches ..... L. curtipes

- Insertion cell at least slightly above base of perithecium, appendages normally developed, with broad cells .... 5

5 Insertion cell near the base of perithecium

....................................... L. murmanica

- Insertion cell in the middle of perithecium ...................................... L. vulgaris

\section{Harpalus}

1 Perithecium yellow, poorly pigmented, lip cells brownblack ......................... Laboulbenia ophoni

- Perithecium more or less brownish-blackish .....................

2 Perithecium small, rather narrow, appendages long, branching once .......................... L. filifera

- Perithecium, broad, appendages shorter, branching several times ............................ L. compressa

Laccophilus

1 Perithecium blunt ............ Chitonomyces melanurus

- Perithecium pointed ..................... C. paradoxus 
Oxytelus

1 One, three or five secondary axes, appendages more or less blackish brown ..... Monoicomyces sanctae-helenae

- One or two secondary axes, appendages pale, only basal septum black ................................... 2

2 Two secondary axes, furcate appearance ... M. furcatus

- One secondary axis .............................. 3

3 Secondary axis with $4-7$ cells $\ldots \ldots \ldots \ldots . . .$. M. oxyteli

- Secondary axis with 2-3 cells, in Fennoscandia known only on Platystethus (Staphylinidae) ....... M. invisibilis

\section{Patrobus}

1 Cell V with secondary divisions, no distinct insertion cell

................................. Laboulbenia fasciculato

- Cell V not secondarly divided, insertion cell distinct, accidental parasites ............................. 2

2 Appendages strongly branched .......... L. pseudomasei

- Appendages poorly branched ............ L. flagellata

\section{Philonthus}

1 Normally one perithecium, asymmetric, on $P$. debilis ... .............................. Dichomyces nigrescens

- Normally two perithecia, symmetric, on other hosts 2

2 Elongated, pale yellow, without black spots near the base (except for the black foot) ........... D. princeps

- At least with black spots near the base, usually with brown-black lateral projections, broader appearance 3

3 Perithecium with long auricles on tip ...... D. biformis

- Perithecium with short auricles or lacking auricles ... 4

4 Long, black, lateral projections, first tier of cells above the foot much narrower than second tier, two perithecia ........................................ D. hybridus

- Lateral projections shorter, paler or lacking, width of first tier of cells above the foot equal to or at least twothirds of width of second, or more than two perithecia 5

5 Broader habitus, two - four perithecia ... D. vulgatus

- Narrower habitus, usually with two perithecia ...... 6

6 Straight perithecia ........................ D. furcifer

- Perithecia bent outwards

$$
\text { D. furcifer subsp. subarcticus }
$$

\section{Pterostichus}

1 Appendages strongly branched Laboulbenia pseudomasei - Outer appendage long, simple, inner appendage short, rarely long, simple ....................... argutoris

Quedius

1 Antheridial branches short, hidden among sterile branches, small species, $200-250 \mu \mathrm{m}$ in length .............. Symplectromyces rarus

- Antheridial branches long, clearly visible, larger species, more than $300 \mu \mathrm{m}$ in length ..................... 2

2 Asymmetric, usually one larger and one smaller perithecium, stalk of perithecium relatively short, uniformly darkening upwards .......................S. vulgaris

- Symmetric, perithecia equal in size, stalk of perithecium

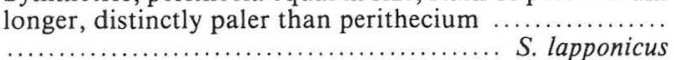

Trechus

1 Insertion cell distinctly below middle of perithecium ... Insertion cell in the middle of perithecium, accidental parasite .................................. L. vulgaris

\section{B Dipteran genera}

\section{Ephydra and Setacera}

1 Lip cells of perithecium about equal in size ............. ............................... Stigmatomyces ephydrae

- Lip cells of perithecium distinctly different in size ... 2
2 Cells below shorter lip cells slightly inflated ...................................................

- Cells below shorter lip cells strongly inflated

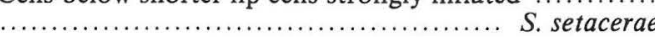

Limosina

1 No swellings in upper region of venter of perithecium, the black foot unusually large $\ldots \ldots \ldots \ldots \ldots \ldots \ldots \ldots \ldots . . . \ldots \ldots$ ............................. Stigmatomyces hackmani

- Four swellings in upper region of venter of perithecium,

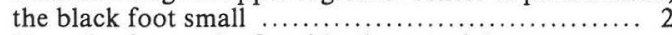

2 Very slender, neck of perithecium straight

.................................... S. subterraneus

- More robust, neck of perithecium curved

S. chthonicus

\section{Ochthera}

1 Perithecium: Neck longer than venter, about one-third of width of venter ........... Stigmatomyces manicatae

- Perithecium: Neck shorter than venter, about half width of venter $\ldots \ldots \ldots \ldots \ldots \ldots \ldots \ldots \ldots \ldots \ldots \ldots \ldots \ldots$. mantis

\subsection{Review of the species}

The genera and species of the Laboulbeniales found in Eastern Fennoscandia are given in alphabetical order.

\section{Asaphomyces tubanticus}

Barbariella tubantica Middelhoek \& Boelens in Middelhoek 1949:260. - Asaphomyces tubanticus (Middelhoek \& Boelens) Scheloske 1969:92.

$$
\text { — Figs. } 26 \text { a-j, } 114 \text { (map). }
$$

There has been some confusion conserning the identity of this species in Europe. Majewski (1973a) and Rossi (1975) reported S. cholevae Thaxter from Europe and Balazuc (1971) considered $A$. cholevae and A. tubanticus to be conspecific. According to Dr. I. Tavares (pers. comm.), A. cholevae is an American species with a more blunt perithecium than in the European $A$. tubanticus. The Fennoscandian material seems to fit $A$. tubanticus in this respect but otherwise there is broad intraspecific variation. Specimens from Sciodrepoides watsoni (Spence) (Figs. $26 \mathrm{~h}-\mathrm{i}$ ) seem to be simpler and slightly smaller than those on Catops spp. A. cholevae was originally described from Sciodrepoides fumatus (Spence) ('Choleva terminans'), which is closely related to $S$. watsoni (both occurring in Europe) and it is not impossible that both Asaphomyces species occur in Europe. More studies are required on possible differences in host specificity between the species.

\section{Material examined}

Finland. Al: Lemland (Catops nigrita). - Ab: Turku, Ruissalo (C. nigrita). Lohja (C. nigrita, C. fuscus, Sciodrepoides watsoni). - N: Ekenäs ( $S$. watsoni). Espoo (C. nigrita, $S$. watsoni). Vantaa (C. nigrita). - Ta: Hattula (C. nigrita). Nokia (S. watsoni). - Kb: Juuka (C. fuscus). - Om: Raahe (C. nigricans). - Li: Inari (C. alpinus).

U.S.S.R. Karelian A.S.S.R.: Vojatsu (C. alpinus). - Leningrad Region: Gumbaritsa (C. fuliginosus).

\section{General distribution}

Czechoslovakia (Banhegyi 1950), Federal Republic of Germany (Scheloske 1969), Finland, France (Balazuc 1973- 
74), Italy (Rossi 1975), Netherlands (Middelhoek 1947), Poland (Majewski 1973a), Sweden (Huggert 1973), U.S.S.R. (Karelian A.S.S.R.; Leningrad Region).

\section{Host}

Genera of Catops, Catopoides and Sciodrepoides (Coleoptera, Catopidae). The parasite occurs on the pronotum and elytra of the host.

\section{Autophagomyces falcatus}

Autophagomyces falcatus Majewski 1973b:229. - Figs. 15 a-g, 115 (map).

The species was described from Polish specimens of Cryptophagus pilosus Gyllenhal. According to Majewski (1973b), A. falcatus is recognized by the very short and broad stalk cell of the perithecium, which lacks a constriction near the base. In the Finnish material, however, this constriction is more or less clearly visible. The Finnish specimens have also a more elongated perithecium and the thallus is somewhat larger than the Polish specimens $(120-140 \mu \mathrm{m}$ and $97-110 \mu \mathrm{m}$ in length respectively). Specimens from the apex of the elytron are very long and strange-looking, because the stalk cell of the perithecium is strongly arcuate distally to the constriction and the basal cells of the perithecium are greatly prolonged.

According to Dr. I. Tavares (pers. comm.), the Finnish material may represent a new species, but for the present I am placing the material under Autophagomyces falcatus.

\section{Material examined}

Finland. Al: Sund (Cryptophagus pilosus). - Ab: Lohja ( $C$. pilosus). Karjalohja (C. setulosus). - N: Hangö, Tvärminne (C. setulosus). - Om: Raahe (C. bimaculatus).

\section{General distribution}

Finland, Poland (Majewski 1973b).

\section{Host}

Cryptophagus spp. (Coleoptera, Cryptophagidae). The parasite occurs on the elytra of the host.

Cantharomyces aploderi Huldén n.sp. - Figs. 32 a-b, 116 (map).

Flavo-brunneus. Pedunculus cellula basali et subbasali receptaculi confectus valde geninculatus, 60 mm longus. Cellula subbasalis macula magna nigra praedita. Antheridium compositum in cellula II appendiculata, cellula III appendiculata applanata. Pedunculus perithecii

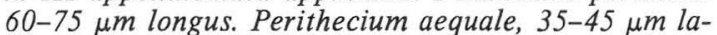
tum, 100-120 $\mu \mathrm{m}$ longum. Sporae $3 \times 35 \mu \mathrm{m}$. Tota longitudo 250-365 $\mu \mathrm{m}$. Matrix: Aploderus caesus (Erichson) (Coleoptera, Staplylinidae).

Receptacle. Yellowish brown, a large black spot on the second cell opposite to the perithecium. The two cells forming a strongly geniculate stalk, about $60 \mu \mathrm{m}$ in length. First cell small, about $20 \mu \mathrm{m}$ long and 12 $\mu \mathrm{m}$ wide. Second cell with a constriction in basal part, upwards broadening to a width of $25-30 \mu \mathrm{m}$.

Appendage. Yellowish, with brown shade, sometimes dark brown in the upper region of first cell. Second cell somewhat longer, compound antheridium visible in outer part. Third and fourth cells about $20 \mu \mathrm{m}$ wide and very flat, 5-10 $\mu \mathrm{m}$ long.
From inner, upper part of fourth cell (or sometimes from third cell) arise two branches, $50-60 \mu \mathrm{m}$ long and $5 \mu \mathrm{m}$ wide. In outer part of fourth cell a broad cell is visible, the distal part of the branch (or other structures) always broken.

Perithecium. Yellowish brown, with brown shade in the septa between cells. Stalk cell arising laterally from upper part of second cell of receptacle, $60-75$ $\mu \mathrm{m}$ long, $15-28 \mu \mathrm{m}$ wide gradually tapering towards base. Perithecium straight, $100-120 \mu \mathrm{m}$ long, $35-45$ $\mu \mathrm{m}$ wide, broadest in middle or just below middle. Apically regularly tapered. Spores $3 \times 35 \mu \mathrm{m}$. Spores seem to germinate within the perithecium, producing the typical black foot before leaving the perithecium, basal part forward.

Total length from base of foot to tip of perithecium $180-235 \mu \mathrm{m}$.

Host. Aploderus caesus (Erichson) (Coleoptera, Staphylinidae). The parasite occurs all over the host: Head, antennae, legs, prothorax, dorsal and ventral part of abdomen.

Holotype. Slide L. Huldén 24, in MZH. Collecting data of the host: U.S.S.R. Karelian A.S.S.R.: Zaoneskje, Sungu, leg. Poppius.

The new species closely resembles $C$. bledii Thaxter, described on Bledius sp. (Coleoptera, Staphylinidae) from North America. It differs from $C$. bledii in the larger and more prolonged second cell of the receptacle and in the very broad cells above the compound antheridium, these being small and narrow in C. bledii (illustrated in Thaxter 1896). The margins in the apical part of the perithecium are concave in $C$. bledii but convex in $C$. aploderi. Two perithecia seem to be typical of $C$. bledii (also in European specimens as illustrated by Siemaszko \& Siemaszko 1932), while all the examined specimens of $C$. aploderi had only one perithecium.

Another related species, $C$. numidicus, described by Maire (1920) on Carpelimus mannerheimi (Kolenati) from Algeria, differs from $C$. aploderi by the shape of the perithecium and the appendage (cf. Rossi \& Cesari Rossi 1978).

Material examined

See the type.

\section{Cantharomyces italicus}

Cantharomyces italicus Spegazzini 1915c:42. - Figs. 28 a-c, 117 (map).

Some specimens may have the base of the subbasal cell of the receptacle pigmented with black (Fig. 28c), thus resembling the closely related $C$. denigratus Thaxter. The latter species, however, should have a much more strongly pigmented subbasal cell and darker perithecium.

Material examined

Finland. Ob: Rovaniemi, Pisavaara (Dryops griseus).

U.S.S.R. Murmansk Region: Pečnga (Petsamo) (D. griseus).

General distribution

Federal Republic of Germany (Scheloske 1969), Finland, Italy (Spegazzini 1915c), Poland (Siemaszko \& Siemaszko 1933), United Kingdom (Thaxter 1931), U.S.S.R. (Murmansk Region). 
Host

Dryops spp. (Coleoptera, Dryopidae). The parasite occurs on the elytra and tip of abdomen of the host.

\section{Cantharomyces orientalis}

Cantharomyces orientalis Spegazzini 1915c:43 Cantharomyces abbreviatus Maire 1920:131. Synonymy according to Scheloske 1969:94. - Figs. 31 a-c, 118 (map).

The closely related Cantharomyces thaxteri Maire is said to be restricted to Carpelimus dilatatus (Erichson) and Carpelimus bilineatus Stephens, and Cantharomyces venetus Spegazzini has been described on Carpelimus rivularis (Motschulsky). Cantharomyces abbreviatus was described on Carpelimus corticinus (Gravenhorst). In view of the broad variation in Cantharomyces orientalis reported by Scheloske (1969), Cantharomyces abbreviatus can certainly be considered to be a synonym of that species. The Fennoscandian material of Cantharomyces orientalis on Carpelimus corticinus is similar to that on Carpelimus elongatulus (Erichson), except for the somewhat longer basal cells of the perithecium.

\section{Material examined}

Finland. N: Espoo (Carpelimus elongatulus).

U.S.S.R. Karelian A.S.S.R.: Oz. Olanga (Paanajärvi) (C. corticinus).

\section{General distribution}

Algeria (Maire 1920), Federal Republic of Germany (Scheloske 1969), Finland, Italy (Spegazzini 1915c), Netherlands (Middelhoek 1949, wrongly as C. thaxteri according to Scheloske 1969), Poland (Siemaszko \& Siemaszko 1932), U.S.S.R. (Karelian A.S.S.R.).

\section{Host}

Carpelimus (Trogophloeus) corticinus, C. subtilicornis (Roubal) and C. elongatulus (Coleoptera, Staphylinidae). The parasite can occur anywhere on the host.

\section{Chitonomyces bidessarius}

Heimatomyces bidessarius Thaxter 1893:185. - Chitonomyces bidessarius (Thaxter) Thaxter 1896:292.

$$
\text { - Figs. 47, } 119 \text { (map). }
$$

Material examined

Finland. Ab: Lohja (Hygrotus inaequalis). - N: Hyvinkää (H. inaequalis).

\section{General distribution}

Federal Republic of Germany (Scheloske 1969), Fiji (Thaxter 1924), Finland, France (Picard 1913), Japan (Sugiyama 1973), Poland (Siemaszko \& Siemaszko 1928), Taiwan (Sugiyama \& Hayama 1981), U.S.A. (Thaxter 1924).

\section{Host}

Genera of Bidessus, Guignotus, Hygrotus and Hyphydrus (Coleoptera, Dytiscidae). The parasite occurs laterally on elytra of the host.

\section{Chitonomyces melanurus}

Chitonomyces melanurus Peyritsch 1873:250. - Figs. 46, 120 (map).

Material examined

Finland. N: Espoo (Laccophilus minutus).
General distribution

Algeria (Maire 1920), Austria (Peyritsch 1873), Cameroon (Siemaszko \& Siemaszko 1933), China (Thaxter 1924), Federal Republic of Germany (Scheloske 1969), Finland, Italy (Colla 1934), Japan (Thaxter 1924), Poland (Siemaszko \& Siemaszko 1933), Taiwan (Sugiyama \& Hayama 1981), United Kingdom (Bisby \& Haker 1940), U.S.S.R. (Ukraina: Koval 1974), Yugoslavia (Banhegyi 1960).

Host

Laccophilus spp. (Coleoptera, Dytiscidae). The parasite occurs mainly on the lateral margin of the left elytron.

\section{Chitonomyces paradoxus}

Heimatomyces paradoxus Peyritsch 1873:251.-Chitonomyces paradoxus (Peyritsch) Thaxter 1895:287.Chitonomyces truncatus Spegazzini 1915c:47. - Figs. 48 a-b, 121 (map).

Material examined

Finland. N: Espoo (Laccophilus minutus).

\section{General distribution}

Austria (Peyritsch 1873), Federal Republic of Germany (Scheloske 1969), Finland, Indonesia (Java, Sumatra: Thaxter 1924), Italy (Spegazzini 1915c), Jamaica (Thaxter 1924), Japan (Sugiyama 1977), Poland (Siemaszko \& Siemaszko 1933), Taiwan (Sugiyama \& Shazawa 1977), United Kingdom (Bisby \& Haker 1940), U.S.S.R. (Baltic Republics: Koval 1974), U.S.A. (Thaxter 1924), Yugoslavia (Banhegyi 1960).

\section{Host}

Laccophilus spp. (Coleoptera, Dytiscidae). The parasite occurs mainly on the lateral margin of the left elytron. Koval's (1974) report of finds on Gyrinus spp. (Coleoptera, Gyrinidae) and Haliplus spp. (Coleoptera, Haliplidae) is probably erroneous.

\section{Corethromyces henrotii}

Corethromyces henrotii Balazuc 1973, in Balazuc 1973-74, vol.42:283.

$$
\text { - Figs. } 27 \text { a-c, 109, } 122 \text { (map). }
$$

The Finnish material resembles the specimen illustrated by Rossi (1975). Both differ somewhat from the illustration of the type (Balazuc 1971a), in which the stalk cell of the perithecium is longer and the perithecium shorter; it is possible an immature specimen.

Material examined

Finland. Ok: Suomussalmi (Choleva septentrionis).

General distribution

Finland, France (Balazuc 1971a), Italy (Rossi 1975).

Host

Choleva oblonga Latreille, $C$. septentrionis Jeannel and $C$. sturmi Brisout de Barneville (Coleoptera, Catopidae). The parasite occurs on the elytra of the host.

\section{Corethromyces niger}

Corethromyces niger Majewski 1973a:114. - Laboulbenia ptomaphagi Huggert 1973:249, according to $\mathrm{Ba}$ lazuc 1974 in Balazuc 1973-74, vol. 43:367.

$$
\text { - Figs. } 13 \text { a-e, } 123 \text { (map). }
$$

The species seems to occur in two variants, one with a smaller and more pointed perithecium and one with a 
larger and more prolonged perithecium with distinct lip cells at the apex. It is possible that the former is immature. The minute size of the parasite $(50-80$ $\mu \mathrm{m})$ makes it difficult to observe on its host.

Dr. I. Tavares has informed me that this species will be transferred to a new genus.

\section{Material examined}

Finland. Ab: Pargas (Ptomaphagus subvillosus).

U.S.S.R. Leningrad Region: Uslanka (P. subvillosus).

\section{General distribution}

Czechoslovakia (Huggert 1973), Denmark (Huggert 1973), Finland, France (Balazuc 1973-74), Italy (Balazuc 197374), Poland (Majewski 1973a), Sweden (Huggert 1973), U.S.S.R. (Leningrad Region).

Host

Ptomaphagus spp. (Coleoptera, Catopidae). The parasite occurs on the elytra, mainly near the suture.

\section{Dichomyces biformis}

Dichomyces biformis Thaxter 1900:422. - Figs. 41 a-b, 124 (map).

The material from the Murmansk Region consists of a morph with well-developed processes arising from the tip of the perithecium. According to Thaxter (1908), both this and a morph without such processes occur in the U.S.A.

\section{Material examined}

U.S.S.R. Murmansk Region: Pečenga (Petsamo) (Philonthus umbratilis). Kuzomen (P. umbratilis).

\section{General distribution}

Belgium (Collart 1945), Japan (Sugiyma 1973), Poland (Siemaszko \& Siemaszko 1932), Portugal (Madeira: Thaxter 1908), United Kingdom (Thaxter 1908), U.S.A. (Thaxter 1908), U.S.S.R. (Murmansk Region).

\section{Host}

Philonthus umbratilis (Gravenhorst), P. rigidicornis (Gravenhorst), $P$. rigidicornis (Gravenhorst) and $P$. micanticollis Sharp (Coleoptera, Staphylinidae). The first-mentioned species is apparently the main host. The parasite occurs on the abdomen of the host.

\section{Dichomyces furcifer}

Dichomyces furciferus Thaxter 1893:184, em. Saccardo 1895:447.

$$
\text { - Figs. } 39 \text { a-c, } 125 \text { (map). }
$$

The species has two morphs: one with long black lateral projections and an auriculate perithecium and the other with short lateral projections and a slightly larger non-auriculate perithecium. Both often occur together on the same host.

\section{Material examined}

Finland. Ab: Uusikaupunki (Philonthus discoideus). Karjalohja ( $P$. albipes). Karis ( $P$. albipes). Lohja $(P$. albipes $) .-\mathrm{N}$ : Vantaa ( $P$. discoideus). - Ta: Kangasala ( $P$. discoideus). Ob: Rovaniemi, Pisavaara ( $P$. puella). known at least from the Federal Republic of Germany (Scheloske 1969), Finland, the Netherlands (Middelhoek 1943a) and the United Kingdom (Bisby \& Mason 1940).

\section{Host}

Philonthus spp., Eulissus chloropterus Erichson (Coleoptera, Staphylinidae). The parasite occurs all over the host, mainly on the abdomen.

Dichomyces furcifer subsp. subarcticus Huldén n.subsp.

- Figs. 38, 126 (map).

Dichomyceti furcifero similis habitu perithecii excepto. Perithecia in margine interiore turgida, extrorsum flexa. Margo exterior concavus, leviter brunneo-umbratus. Apex perithecii auriculatus. Perithecium 70-74 $\mu \mathrm{m}$ longum. Matrix: Philonthus albipes (Gravenhorst) (Coleoptera, Staphylinidae).

Resembles Dichomyces furcifer, except for the different habitus of the perithecia. The two mature perithecia are outwards curving with the inner margins inflated and the outer margins concave and with a faint brown shade. Uniformly tapered from the middle towards the tip. Tip of perithecia with typical auricles. Size of perithecium $21-23 \times 70-74 \mu \mathrm{m}$.

Host: Philonthus albipes (Gravenhorst) (Coleoptera, Staphylinidae). The parasite was found on the three apical segments of the abdomen.

Holotype. Slide L. Huldén 10, in MZH. Collecting data of the host: U.S.S.R. Murmansk Region: Pečenga (Petsamo), leg. W. Hellén.

Material examined

See the type.

Dichomyces hybridus

Dichomyces hybridus Thaxter 1900:423. - Figs. 44, 127 (map).

Only the non-auriculate morph occurs in Finland. The auriculate morph seems to be restricted to Asia: China, Japan and India (Thaxter 1908).

Material examined

Finland. Ab: Uusikaupunki (Philonthus debilis, P. ventralis). Karjalohja ( $P$. ventralis). Lohja ( $P$. ventralis $)$. - Ta: Pälkäne $(P$. ventralis $)$.

\section{General distribution}

Widely distributed in the Nearctic, Palaearctic and Oriental Regions (Thaxter 1908). In Europe known from Finland and the United Kingdom (Bisby \& Mason 1940).

Host

Philonthus spp. (Coleoptera, Staphylinidae). The parasite occurs mainly on the abdomen but also on the elytra, tibiae and tarsi of the host.

\section{Dichomyces nigrescens}

Peyritschiella nigrescens Thaxter 1893:184. - Dichomyces inaequalis 1894:103. - Dichomyces nigrescens (Thaxter) Scheloske 1969:106. 
This is the smallest of the North European Dichomyces species. It is recognized by the asymmetric habit and seems to be restricted to one host: Philonthus debilis (Gravenhorst).

\section{Material examined}

Finland. Ab: Uusikaupunki. Lohja. - N: Hangö, Tvärminne. Vantaa. Helsinki. - St: Rauma. - Sa: Ristiina. - Oa: Lappfjärd. - Tb: Viitasaari. - Sb: Joroinen. - Kb: Kontiolahti. All records on Philonthus debilis.

U.S.S.R. Leningrad Region: Poljany (Uusikirkko). Vesnino (Pyhäjärvi). Mičurinskoe (Valkjärvi). - Kareliąn A.S.S.R.: Sortavala. Ahvenjärvi. - Murmansk Region: Cavanga. On P. debilis.

\section{General distribution}

Federal Republic of Germany (Scheloske 1969), Finland, France (Balazuc 1973-74), Italy (Colla 1934), Taiwan (Sugiyama 1978), United Kingdom (Bisby \& Mason 1940), U.S.A. (Thaxter 1893), U.S.S.R. (Karelian A.S.S.R.; Leningrad Region; Murmansk Region).

\section{Host}

Philonthus debilis (Coleoptera, Staphylinidae). The parasite occurs mainly on the abdomen of the host.

\section{Dichomyces princeps}

Dichomyces princeps Thaxter 1895:479.

$$
\text { - Figs. } 42 \text { a-b, } 129 \text { (map). }
$$

This species may be confused with pale variants of $D$. vulgatus. $D$. princeps is more elongated, however, and usually lacks black spots above the foot. The earlier illustration of $D$. princeps given by Middelhoek (1941, $1943 \mathrm{a}$ and 1943b) probably represents $D$. vulgatus while the later illustration (Middelhoek 1947) seems to be more typical $D$. princeps. The Finnish material fits very well with the illustration given by Thaxter (1896).

\section{Material examined}

Finland. Ab: Lohja (Philonthus cephalotes).

\section{General distribution}

Apparently cosmopolitan (cf. Thaxter 1895, 1908 and 1931). In Europe known at least from Belgium (Collart 1945), Finland, France (Balazuc 1973-74), Italy (Colla 1934), the Netherlands (Middelhoek 1947), Poland (Majewski 1973b).

\section{Host}

Philonthus spp., Quediomacrus puniceipennis Solsky (Coleoptera, Staphylinidae). The parasite occurs all over the host.

\section{Dichomyces vulgatus}

Dichomyces vulgatus Thaxter 1900:424. - Figs. 40 a-d, 130 (map).

The species occurs in two morphs, as illustrated by Thaxter (1908). Both occur in Fennoscandia (Figs. 30 $a-b$ and $c-d)$. The status of these morphs may be questioned. They are known to occur together on the same host individual. If they are separated it must be at specific level because of their highly sympatric distribution. As there are many species in this group that seem to occur in two morphs, I think it is better to treat D. vulgatus as another of these dimorphic species.
The non-auriculate morph with less black pigment laterally may closely resemble $D$. princeps, but is broader (Figs. 40c and 42a). The specimen in Fig. 40d has produced an extremely large perithecium after being broken.

\section{Material examined}

Finland. Al: Föglö (Philonthus cephalotes). - Ab: Uusikaupunki ( $P$. longicornis). Lohja ( $P$. longicornis, $P$. umbratilis). - Ta: Loppi (P. cephalotes). - Oa: Lappfjärd (P. cephalotes).

U.S.S.R. Leningrad Region: Mičurinskoe (Valkjärvi) ( $P$. fuscus). Zaporozskoe (Metsäpirtti) (P. cephalotes). Uslanka (P. longicornis).

\section{General distribution}

Cosmopolitan (cf. Thaxter 1908). In Europe known from Austria (Thaxter 1908), Finland, France (Balazuc 197374), Italy (Colla 1925), the Netherlands (Middelhoek 1943a), the United Kingdom (Thaxter 1908), U.S.S.R. (Leningrad Region).

Host

Philonthus spp. (Coleoptera, Staphylinidae). Tha parasite occurs mainly on the abdomen but is often also found on other parts of the host.

\section{Dioicomyces anthici}

Dioicomyces anthici Thaxter 1901b:33. - Dioicomyces formicillae f. anthicicola Spegazzini 1917:523, according to Thaxter 1931:62. Dioicomyces anthici var. fuscescens Maire 1920:134

- Figs. 34 a-i, 131 (map).

This is the only dioecious species of the Laboulbeniales in Eastern Fennoscandia. From the beginning the spores are differentiated into male and female spores (Figs. $34 \mathrm{~d}$-e). The male thallus consists of only four superposed cells laterally terminating in the discharge tube of the single antheridium (Figs. $34 \mathrm{f}-\mathrm{i}$ ). Because of its very small size $(40-50 \mu \mathrm{m})$, it is difficult to detect on its host. The female thallus (Figs. 34 a-b) is of 'normal' size.

\section{Material examined}

Finland. Ab: Lohja (Anthicus formicarius). - Ta: Juupajoki (A. floralis).

\section{General distribution}

Algeria (Maire 1916a), Argentina (Spegazzini 1917, as Dioicomyces formicillae f. anthicicola), Cameroon (Thaxter 1931), Finland, Guatemala (Thaxter 1931), Hungary (Banhegyi 1944), Jamaica (Thaxter 1931), Senegal (Spegazzini 1915a), U.S.A. (Thaxter 1931). Being easily overlooked, the species is probably more widely distributed.

\section{Host}

Anthicus spp. (Coleoptera, Anthicidae). The parasite occurs on the elytra of the host.

\section{Diplomyces clavifer}

Diplomyces clavifer Rossi \& Cesari Rossi 1978:65. - Figs. 55 a-d, 132 (map).

This species is rather difficult to observe on its host because of its minute size and dark appearance. The dark appearance is caused by the nearly black up- 
growth starting from the base of receptacle and covering a part of the thallus. In some cases the upgrowth may be almost lacking (Fig. 55b). It is interesting to note that in both the Finnish localities (Geta and Eckerö) it occurs together with Teratomyces brevicaulis in populations of Erichsonius cinerascens (Gravenhorst), though the two parasites have not yet been found on the same host individuals.

\section{Material examined}

Finland. Al: Geta (Erichsonius cinerascens). Eckerö (E. cinerascens).

Sweden. Jämtland: Häggenäs (E. cinerascens).

\section{General distribution}

Finland, Italy (Rossi \& Cesari Rossi 1978), Sweden.

\section{Host}

Erichsonius cinerascens and E. signaticornis Mulsant \& Rey (Coleoptera, Staphylinidae). The parasite was found on the abdomen of the host.

\section{Ecteinomyces agathidii}

Ecteinomyces agathidii Maire 1920:31. - Asaphomyces agathidii (Maire) Scheloske 1969:92. - Figs. 12 a-c, 133 (map).

Scheloske transferred this species to Asaphomyces. However, according to Dr. I. Tavares (pers. comm.) the taxon will be placed in a third genus and for convenience I am now using the original combination.

Cyrtusa subtestacea (Gyllenhal) is a new and possibly only accidental host for $E$. agathidii, as it belongs to the tribus Leiodini, not to the Agathidiini like the previously known host species. Huggert (1973, Fig. 1) described Amphimyces liodivorus from Leiodes, a genus more closely related to Cyrtusa, but his illustrations show that $A$. liodivorus is quite different from my material on Cyrtusa. The species of Leiodidae are said to have subterranean habits and to live mainly on fungal mycelium.

\author{
Material examined \\ U.S.S.R. Karelian A.S.S.R.: Oz. Olanga (Paanajärvi) (Cyr- \\ tusa subtestacea).
}

\section{General distribution}

Federal Republic of Germany (Scheloske 1969), Morocco (Maire 1920), Poland (Majewski 1980), Sweden (Huggert 1973), U.S.S.R. (Karelian A.S.S.R.).

\section{Host}

Amphicyllis globus (Fabricius), Agathidium laevigatum Erichson, $A$. seminulum (Linnaeus), $A$. badium Erichson, $A$. rotundatum (Gyllenhal), Cyrtusa subtestacea (Coleoptera, Leiodidae). The parasite occurs on the pronotum and elytra of the host.

\section{Ecteinomyces trichopterophilus}

Ecteinomyces trichopterophilus Thaxter 1902:26. Misgomyces trichopterophilus (Thaxter) Thaxter 1931:304.

$$
\text { - Figs. } 14 \text { a-c, } 134 \text { (map). }
$$

Thaxter transferred this species to Misgomyces but according to Dr. I. Tavares (pers. comm.) it belongs to Ecteinomyces. The hosts of this parasite are among the smallest beetles, their size ranging from 0.5 to 1.1 $\mathrm{mm}$. The parasite is very difficult to observe on the elytra of the host. I found the fungus on a specimen of Acrotrichis in a collection of undetermined Ptiliidae and unfortunately I was not able to determine the insect to specific level.

\section{Material examined}

Finland. Om: Raahe (Acrotrichis sp.).

General distribution

Argentina (Thaxter 1931), Chile (Thaxter 1931), Federal Republic of Germany (Scheloske 1969), Finland, Italy (Thaxter 1931), Poland (Majewski 1971), U.S.A. (Thaxter 1931).

Host

Acrotrichis spp. (Coleoptera, Ptiliidae). The parasite occurs on the elytra of the host.

Eucantharomyces fennoscandicus Huldén n.sp. - Figs. 18 a-f, 135 (map).

Pallidae brunneus, hyalinus. Cellula basalis et subbasalis lateraliter adnatae, magnitudine fere aequales, circiter $60 \mu \mathrm{m}$ longae. Antheridium compositum antheridiis in tribus ordinibus positis, numerus cellularum antheridiferarum aliquantum variabilis. Antheridium compositum $18 \times 60 \mu \mathrm{m}$. Pedunculus perithecii 40-70 $\mu \mathrm{m}$ longus. Prope apicem perithecii quattuor tumores adsunt. Perithecium 60-70 × 155-215 $\mu \mathrm{m}$. Sporae 3-4 $\times 42$ $\mu \mathrm{m}$. Tota longitudo 250-365 $\mu \mathrm{m}$. Matrix: Agonum quadripunctatum (Degeer) (Coleoptera, Carabidae).

Receptacle. Pale brown, hyaline. Basal cell slightly longer than subbasal cell, nearly identical in shape. Basal cell about $60 \mu \mathrm{m}$ in length.

Appendage. Pale brown, hyaline. Basal cell about twice the length of subbasal cell. Antheridia in three rows, number of antheridial cells in each row variable; the following combinations found: $7: 4: 3,6: 4: 3$ and 4:3:3. Marginal cell extending below middle of subbasal cell, upper part slightly inflated, terminating in a short blunt process. Discharge tube somewhat irregularly curved, $15-18 \mu \mathrm{m}$ in length. Size of compound antheridia about $18 \times 60 \mu \mathrm{m}$.

Perithecium. Pale brown, hyaline. Stalk cell connected to equal degree with basal and subbasal cell of receptacle and basal cell of appendage. Stalk cell variable in length, $40-70 \mu \mathrm{m}$, gradually broadening upwards from $25 \mu \mathrm{m}$ to $33 \mu \mathrm{m}$ in width. Size of perithecium $60-70 \times 155-215 \mu \mathrm{m}$. Four swellings below the blunt tip. Spores about $3-4 \times 42 \mu \mathrm{m}$.

Total length from base of foot to tip of perithecium $250-365 \mu \mathrm{m}$.

Host. Agonum quadripunctatum (Degeer) (Coleoptera, Carabidae). The parasite occurs on all parts of the host.

Holotype. Slide L. Huldén 11, in MZH. Collecting data of the host: Finland. Ob: Muhos, leg. Stockmann.

The new species is closely related to E. atrani Thaxter (1895), which occurs on Atranus pubescens Dejean (Coleoptera, Carabidae) in North America. It is distinguished from $E$. atrani by the broader perithecium, the swellings in the upper part of the perithecium and the small process in the apical part of the marginal 
cell of the compound antheridium. Otherwise the structure of the compound antheridium is very similar to that of $E$. atrani (Thaxter 1896 and 1908).

\section{Material examined}

Finland, Ob: Muhos (Agonum quadripunctatum).

U.S.S.R. Karelian A.S.S.R.: Kumsjärvi (A. quadripunctatum).

\author{
Euzodiomyces lathrobii \\ Euzodiomyces lathrobii Thaxter 1900:449. \\ - Figs. 35 a-d, 136 (map).
}

Material examined

Finland. N: Vantaa (Lathrobium longulum).

General distribution

Algeria (Maire 1916a), Belgium (Collart 1945), Federal Republic of Germany (Scheloske 1969), Finland, France (Balazuc 1973-74), Italy (Rossi 1975), Japan (Sugiyama 1973), Netherlands (Middelhoek 1943c), Poland (Majewski 1973b), Switzerland (Baumgartner 1923), United Kingdom (Thaxter 1908), U.S.A. (Benjamin \& Shanor 1951), Yugoslavia (Banhegyi 1960).

Host

Lathrobium (s.lat.) spp., Homeotarsus bicolor (Gravenhorst), Hemiquedius ferox (LeConte), Xantholinus sp. (Coleoptera, Staphylinidae), also accidentally on Patrobus atrorufus (Ström) (Coleoptera, Carabidae). E. lathrobii seems to be mainly restricted to Lathrobium species. The parasite occurs all over the host.

Fanniomyces copromyzae Huldén n.sp. - Figs. 58 a-b, 137 (map).

Flavidus, hyalinus. Pedunculus cellula basali et subbasali receptaculi confectus 150-160 $\mu \mathrm{m}$ longus. Appendices duae sympodice paniculatae, omnibus ramis in antheridia ampullacea terminantibus. Cellula pedunculi perithecii 20-25 $\mu \mathrm{m}$ longa. Perithecium circiter $180 \mu \mathrm{m}$ longum. Sporae $5 \times 32 \mu \mathrm{m}$. Tota longitudo $330 \mu \mathrm{m}$. Matrix: Copromyza borealis Zetterstedt (Diptera, Sphaeroceridae).

Receptacle. Hyaline. The two cells forming a stalk $150-160 \mu \mathrm{m}$ in length, uniformly $20-24 \mu \mathrm{m}$ in width. The black foot very small. The first cell slightly shorter than the second.

Appendage. Hyaline, with very faint brown shade, which is slightly stronger on stalk cell but absent from basal cell. Basal cell $30-35 \mu \mathrm{m}$ long, about $12 \mu \mathrm{m}$ wide at the broadest part in upper-most third. Slightly constricted at the septum between basal cell and stalk cell. Stalk cell $8-10 \mu \mathrm{m}$ wide, about $18 \mu \mathrm{m}$ long. From the stalk cell arise two appendages, an inner and an outer one. Outer appendage sympodially branched, each branch having short sterile branchlets or flask-shaped antheridia. Basal cell of outer appendage about $25 \mu \mathrm{m}$ long and $10 \mu \mathrm{m}$ wide, the other cells of the same shape but gradually becoming smaller. Inner appendage similar to the outer one but slightly smaller and less branched. The appendages about $80-90 \mu \mathrm{m}$ in length.

Perithecium. Hyaline with very faint brown shade. Spore bearing venter about $80 \mu \mathrm{m}$ long and about 45 $\mu \mathrm{m}$ wide in the central region, broadly spool-formed. Neck slightly outwards bent, $20-25 \mu \mathrm{m}$ in width, slightly tapering towards the base. Apical third of neck forming a regular cone $25 \mu \mathrm{m}$ wide at base and equally high. No processes visible at the tip. Spores $5-32 \mu \mathrm{m}$.

Total length from base of foot to tip of perithecium about $330 \mu \mathrm{m}$.

Host. Copromyza borealis Zetterstedt (Diptera, Sphaeroceridae). The parasite was found on the thorax and left hind femur of the host.

Holotype. Slide L. Huldén 20, in MZH. Collecting data of the host Finland. N: Espoo, Småholmen, 7.VII.1960, leg. W. Hackman.

Fanniomyces copromyzae is closely related to $F$. burdigalensis, described by Balazuc (1979) from France on Sphaerocera pedestris (Meigen) (Diptera, Sphaeroceridae). In $F$. copromyzae, however, the perithecium is more robust, with the neck distally broader, and as far as can be judged, the antheridia are more elongated than in F. burdigalensis.

Material examined

See the type.

Haplomyces texanus

Haplomyces texanus Thaxter 1893:160.

- Figs. 33 a-c, 105, 138 (map).

The basal cells of the perithecium are much shorter in the Fennoscandian material than in the illustrations of typical $H$. texanus by Thaxter (1896) and Rossi \& Cesari Rossi (1980).

Material examined

Finland. Al: Jomala (Bledius diota). - Ab: Lohja (B. gallicus). - N: Tuusula (B. gallicus). - Li: Inari, Ivalo (B. poppiusi).

U.S.S.R. Leningrad Region: Poljany (Uusikirkko) (B. opacus) Zaporožskoe (Metsäpirtti) (B. longulus, B. pallipes). Uslanka (B. filipes). - Murmansk Region: Kuolayarvi (Salla) (B. kutsae). Kandalakša (B. arcticus). Pečenga (Petsamo) (B. vilis).

General distribution

Finland, France (Balazuc 1973-74), Italy (Rossi \& Cesari Rossi 1980), Netherlands (Middelhoek 1943a), U.S.A. (Thaxter 1896), U.S.S.R. (Leningrad Region; Murmansk Region).

Host

Bledius spp. (Coleoptera, Staphylinidae). The parasite occurs on various parts of the host.

Helodiomyces elegans

Helodiomyces elegans Picard 1913:557.

- Figs. 17 a-b, 139 (map).

The material studied was overmature and in bad condition with the appendage and tip of perithecium broken.

Material examined

Finland. Al: Finström (Dryops auriculatus).

General distribution

Algeria (Maire 1916a), Federal Republic of Germany (Scheloske 1969), Finland, France (Picard 1913), Poland (Siemaszko \& Siemaszko 1928), United Kingdom (Hincks 1960). 
Host

Dryops luridus (Erichson), D. auriculatus (Fourcroy) and $D$. algiricus Lucas (Coleoptera, Dryopidae). The parasite occurs on various parts of the host.

\section{Hydraeomyces halipli}

Heimatomyces halipli Thaxter 1892:32. - Hydraeomyces halipli (Thaxter) 1896:294. - Hydraeomyces venetus Spegazzini 1915c:52. - Parahydraeomyces italicus Spegazzini 1915c:70. - Parahydraeomyces italicus var. neopolitanicus Spegazzini 1915c:70. Synonymy according to Siemaszko \& Siemaszko 1933: 125.

$$
\text { - Figs. } 30 \text { a-c, } 140 \text { (map). }
$$

This species is rather heterogeneous. In American specimens (Thaxter 1896), the second and third receptacle cells are narrow, but in Japanese, Taiwanese and European specimens they are broader and more flattened (e.g. Sugiyama 1973, Sugiyama \& Hayama 1981 and Siemaszko \& Siemaszko 1933). European material fairly often contains specimens with four stalk cells in the receptacle. This character is usually coupled with stronger pigmentation, a large basal cell, very flattened second to fourth receptacle cells and more robust appearance of the thallus. This variant was described from Italy (Spegazzini 1915c) as Parahydraeomyces italicus on 'Haliplus striaticollis', a name not occurring in entomological literature, but according to Mainardi (1915) possibly $H$. lineatocollis (Marsham). In Finland this variant is very distinctly separable from the typical variant and occurs on $\mathrm{Ha}$ liplus fulvus lapponum Thomson. A similar variant was found by Scheloske (1969) in Germany on $H$. fulvus (Fabricius) (?ssp. fulvus) and by Banhegyi (1950) in Hungary on $H$. variegatus Sturm. The status of this variant remains unclear as intermediate variants seem to occur (Siemaszko \& Siemaszko 1933 and Scheloske 1969). It is possible that its choice of host is more restricted than in the typical variant. In Fennoscandia Haliplus fulvus lapponum prefers lotic habitats, while the other host species prefer lentic ones (e.g. Palm 1932, Stenius 1932, Lindberg 1937 and Eriksson 1972)

\section{Material examined}

Finland. Al: Geta (Haliplus fulvus fulvus). - Sa: Punkaharju (H. fulvicollis). - Ks: Kuusamo (H. fulvus lapponum). - Lk: Kittilä, Pallastunturi ( $H$. fulvus lapponum).

U.S.S.R. Leningrad Region: Jašino (Vahviala) (H. lineolatus).

\section{General distribution}

Argentina (Spegazzini 1917), China (Thaxter 1924), Federal Republic of Germany (Scheloske 1969), Finland, France (Picard 1913), Hungary (Banhegyi 1950), Japan (Sugiyama 1973), Morocco (Maire 1916a), Poland (Siemaszko \& Siemaszko 1933), Spain (Siemaszko \& Siemaszko 1933), Taiwan (Sugiyama \& Hayama 1981), Tunisia (Maire 1916a), U.S.A. (Thaxter 1892), U.S.S.R. (Leningrad Region).

Host

Haliplus spp., Peltodytes (Cnemidotus) spp. (Coleoptera, Haliplidae). The parasite occurs on the lateral margins of the elytra.

Hydrophilomyces arcuatus Huldén n.sp. — Figs. 19 a-d, 141 (map).
Hyalinus, leviter brunneo-umbratus. Receptaculum ex cellulis 7-15 constans, cellula II cellulam sustinentem curvatam 60-85 $\mu \mathrm{m}$ longam ferens. Appendix ex axe principali cum ramulis lateralibus angustis constat. Perithecium extrorsum flexum. Sporae 3-4 $\times 30 \mu \mathrm{m}$. Matrix: Ochthebius minimus (Fabricius) (Coleoptera, Hydraenidae).

Receptacle. Hyaline, with faint brown shade. Straight or slightly curved, consisting of $7-15$ cells below perithecium. The first cell isodiametric, the second slightly flattened, having a long curved buffer cell, $60-85 \mu \mathrm{m}$ in length. The following cells gradually lengthening, roughly isodiametric just below perithecium. Length of receptacle (35-) 85-120 $\mu$.

Appendage. Hyaline. Like a somewhat laterally placed continuation of the receptacle, but slightly narrower. First to third basal cells simple, but the following cells each with one or two narrow branches. The branches arising from a small triangular cell in the upper corner (or corners) of the main axis cell. Antheridia not distinguished with certainty, possibly occurring on or beside the narrow branchlets, or the branchlet itself constitutes an antheridium. Length of appendage (the main axis) $60-70 \mu$.

Perithecium. Hyaline with faint brown shade. Strongly outwards curved, somewhat inflated along inner margin, broadest in the basal part, without specialized neck. Directed outwards from main axis at an angle of $45-90^{\circ}$. Size $30-35 \times 70-85 \mu \mathrm{m}$. Spores $3-4 \times 30 \mu \mathrm{m}$. Septum of spore near the middle.

Host. Ochthebius minimus (Fabricius) (O. impressus Marsham) (Coleoptera, Hydraenidae). The parasite occurs near the apex of the elytra.

Holotype. Slide L. Huldén 8, in MZH. Collecting data of the host: Finland. Ab: Lohja, 29.VI.1942, leg. Harald Lindberg.

Hydrophilomyces arcuatus is easily recognized by the habitus of the perithecium with the short unspecialized neck curving evenly outwards. All the other species of the genus seem to have a long differentiated neck on the perithecium, like that in the closely related $H$. digitatus, which was described on O. marinus (Paykull) from France (Picard 1910).

Material examined

See the type.

Laboulbenia argutoris

Laboulbenia argutoris Cépède \& Picard 1909:260. - Figs. 92 a-c, 142 (map).

In the typical appearance of $L$. argutoris the inner appendage is short, sometimes branched, terminating in two or four (sometimes more) antheridia. Occasionally, the Finnish material contains a variant with a long unbranched inner appendage, with one antheridium arising at the normal level, from the third cell (Fig. 92a).

This ectoparasite is the host of a hyperparasite, discussed in section 8.4.

Material examined

Finland. Al: Finström. Eckerö. Sund. Geta. - Ab: Korpo. 
Lohja. Turku. - N: Hangö, Tvärminne. Espoo. Tuusula. Ekenäs. Sibbo. - St: Pori, Reposaari. - Ks: Kuusamo. All records on Pterostichus diligens.

U.S.S.R. Leningrad Region: Vyborg (Viipuri). - Karelian A.S.S.R.: Suistama (Suistamo). On P. diligens.

\section{General distribution}

Federal Republic of Germany (Scheloske 1969), Finland, France (Cépède \& Picard 1909), Hungary (Banhegyi 1949), Italy (Spegazzini 1914), Poland (Siemaszko \& Siemaszko 1928), Romania (Balazuc 1973), Switzerland (Baumgartner 1923), U.S.S.R. (Leningrad Region; Karelian A.S.S.R.).

\section{Host}

Pterostichus spp., accidentally also on Patrobus atrorufus (Ström) (Coleoptera, Carabidae). The parasite occurs on various parts of the host.

Laboulbenia bradycelli

Laboulbenia bradycelli Balazuc 1974, in Balazuc 1973-74, vol.43:15.

$$
\text { - Figs. 76, } 143 \text { (map). }
$$

The main host of L. bradycelli is probably Trichocellus placidus (Gyllenhal). On Bradycellus species in Finland I have found only Laboulbenia polyphaga Thaxter.

\section{Material examined}

Finland. Al: Finström. - Ab: Turku, Ruissalo. Lohja. - N: Helsinki. Espoo. Vantaa. Hangö, Tvärminne. - Ta: Hattula. Lammi. - Sa: Joutseno. - Oa: Lappfjärd. — Sb: Vehmersalmi. All records on Trichocellus placidus.

U.S.S.R. Karelian A.S.S.R.: Sortavala. - Murmansk Region: Kandalakša. On T. placidus.

\section{General distribution}

Finland, France (Balazuc 1973-74), Poland (Majewski 1980), U.S.S.R. (Karelian A.S.S.R.; Murmansk Region).

\section{Host}

Trichocellus placidus, Bradycellus spp. (Coleoptera, Carabidae). The parasite occurs on various parts of the host.

\section{Laboulbenia carelica Huldén n.sp.}

$$
\text { - Figs. } 88 \text { a-c, } 144 \text { (map). }
$$

Brunneus - fuscus. Pedunculus cellulis I-II confectus 90-95 $\mu \mathrm{m}$ longus, 12-18 $\mu \mathrm{m}$ latus. Cellula insertionis in medio perithecii. Appendix apicem perithecii superans. In parte superiore perithecii tumores duo adsunt. Tota longitudo $115 \mu \mathrm{m}$. Matrix: Bembidion doris (Panzer) (Coleoptera, Carabidae).

Receptacle. Brown, dark brown in the region of septum of cells I-II and outer part of cell III. Cells I-II forming a stalk of uniform width, $12-18 \mu \mathrm{m}$, and $90-95 \mu \mathrm{m}$ long. Cell II about 1.5 times the length of cell I. Cell III about as long as or somewhat longer than the width of cell IV. Cell V rather small, narrow or nearly triangular.

Appendages. Insertion cell about $12 \mu \mathrm{m}$ in width, in middle of perithecium. Basal cell of outer appendage brown, inflated and only slightly smaller than cell IV. The basal cells of the two inner appendages brown, somewhat narrower that of the outer appendage. The upper part of the appendages are damaged, but they are at least somewhat longer than the perithecium.
Antheridia not observed.

Perithecium. Dark brown, paler in the upper region, with black spots on the lip cells. Broadest in the upper part because of two symmetrically placed nearly pointed swellings. Width at the base about $21 \mu \mathrm{m}$ and at the swellings about $30 \mu \mathrm{m}$, above the swellings the perithecium tapering abruptly to the tip. About $55 \mu \mathrm{m}$ long. Spores not observed.

Total length from base of foot to tip of perithecium $155 \mu \mathrm{m}$.

Host. Bembidion doris (Panzer) (Coleoptera, Carabidae). On elytra of the host.

Holotype. Slide L. Huldén 2, in MZH. Collecting data of the host: U.S.S.R. Karelian A.S.S.R.: Suistama (Suistamo), leg. O. Renkonen. Holotype from the right elytron of the host.

The material of this species was overaged with damaged appendages. The species is, however, very characteristic with the two swellings on the perithecium and strong dark brown pigmentation on the thallus. The host, Bembidion doris, is widely distributed and due to this fact $L$. carelica is also likely to be widespread.

\section{Material examined}

U.S.S.R. Leningrad Region: O. Lesnoj (Seiskari). - Karelian A.S.S.R.: Suistama (Suistamo).

\section{Laboulbenia clivinalis}

Laboulbenia clivinalis Thaxter 1899:165. - Laboulbenia henricii Colla 1927:185. - Figs. 83, 145 (map).

\section{Material examined}

Finland. Al: Mariehamn. - N: Helsinki. Espoo. - St: Pori, mainland and Reposaari. - Ta: Hattula. Aitolahti. Orivesi. Jokioinen. - Sa: Rantasalmi. Joutseno. - Oa: Kurikka. Vaasa. - Kb: Pyhäselkä, Hammaslahti. - Om: Nivala. Kokkola. - Ok: Vaala, Säräisniemi. - Ob: Oulu. All records on Clivina fossor.

U.S.S.R. Leningrad Region: Rjabino (Kuolemajärvi). Vesnino (Pyhäjärvi). Pervomajskoe (Kivinebb). - Murmansk Region: Pečenga (Petsamo). All records on C. fossor.

\section{General distribution}

Algeria (Maire 1916a), Federal Republic of Germany (Scheloske 1969), Finland, France (Balazuc 1973-74), Hungary (Banhegyi 1940), Italy (Thaxter 1908), Philippines (Thaxter 1908), Poland (Siemaszko \& Siemaszko 1928), Spain (Balazuc et al. 1982), Switzerland (Baumgartner 1923), United Kingdom (Thaxter 1908), U.S.S.R. (Leningrad Region; Murmansk Region; Latvian S.S.R.: Briedis 1932).

\section{Host}

Clivina spp., accidentally also on Patrobus atrorufus (Ström) (Coleoptera, Carabidae). The parasite occurs all over the host.

\section{Laboulbenia compressa}

Laboulbenia compressa Thaxter 1893:165. - Figs. 94 a-b, 146 (map).

This material of Laboulbenia, found on several species of Harpalus, is only tentatively placed under L. compressa, in some cases it is difficult to separate from $L$. filifera. It is pale to bright yellow with a dark brown perithecium. The appearance is more robust and the 
outer appendage is shorter and normally more branched than in L. filifera. The tip of the perithecium is slightly broader than in the illustration of $L$. compressa given by Thaxter (1896), but otherwise it fits the description of the species. It also shows some resemblance to $L$. ophoni subsp. fuscula described by Spegazzini (1914). These observations indicate that many of the described species, such as $L$. ophoni, $L$. filifera and some other related species, are not yet sufficiently studied and delimited. All the European material should evidently be compared with American material before the exact identity of the taxa is resolved.

L. compressa has not previously been reported from Europe.

\section{Material examined}

Finland. Al: Jomala (Harpalus xanthopus winkleri). - Ab: Lohja (H. affinis). - N: Hangö, Tvärminne ( $H$. affinis). Helsinki (H. tardus). - St: Pori (H. affinis). Tyrvää $(H$. affinis). - Sa: Mikkeli (H. affinis). Ruokolahti (H. affinis). Joutseno (H. affinis). - Tb: Viitasaari (H. affinis, H. latus). - Om: Tervajärvi (H. affinis).

U.S.S.R. Leningrad Region: Iskra (Muolaa) (H. tardus). Uslanka (H. affinis). Vaašeni (H. affinis). - Karelian A.S.S.R.: Salmi (H. affinis). Petroskoi (H. affinis).

General distribution

Finland, U.S.A. (Thaxter 1893), U.S.S.R. (Leningrad Region; Karelian A.S.S.R.)

Host

Harpalus spp., Anisodactylus baltimoriensis Say (Coleoptera, Carabidae). The parasite was found mostly on the elytra of the host.

\section{Laboulbenia curtipes}

Laboulbenia curtipes Thaxter 1892:40. — Figs. 78, 102, 147 (map).

This species was described from the U.S.A. on Bembidion bimaculatum Kirby (belonging to subg. Peryphus). However this host species, like all its allies, is a larval hibernator (Lindroth 1945 and 1963) and can only be an accidental host for $L$. curtipes. The European hosts belong to subg. Notaphus (imaginal hibernators) and the American hosts most probably also belong to this subgenus. There are at least 17 such species in North America, and one of them, namely $B$. semipunctatum (Donovan), is one of the hosts in Fennoscandia. The parasite grows typically on the tarsi and distally on the tibiae of the host (Fig. 102).

The European material of $L$. curtipes fits the description of the species (Thaxter 1892, illustrated in Thaxter 1896), but seems to be slightly paler. L. curtipes has not previously been reported form Europe.

\section{Material examined}

Finland. Ab: Lohja (Bembidion obliquum). - N: Vantaa ( $B$. dentellum). Espoo (B. obliquum). Espoo (B. obliquum). - St: Karkku (B. obliquum). - Ta: Hattula (B. varium). Hauho (B. varium). Tampere, Messukylä (B. obliquum). Sääksmäki (B. obliquum). - Sa: Kangasniemi (B. obliquum). - Tb: Jyväskylä (B. obliquum).

U.S.S.R. Leningrad Region: Zaporožskoe (Metsäpirtti) ( $B$. obliquum, $B$. semipunctatum). Molodežnoe (Vammeljoki) ( $B$. obliquum, B. semipunctatum). Rjabino (Kuolemajärvi) (B. obliquum). Sestroretsk (Rajajoki) (B. obliquum). Gumbaritsa (B. obliquum). Uslanka (B. obliquum).

General distribution

Finland, U.S.A. (Thaxter 1892), U.S.S.R. (Leningrad Region).

\section{Host}

Bembidion: subg. Notaphus (incl. B. dentellum (Thunberg), accidentally on $B$. bimaculatum (subg. Peryphus). The parasite occurs distally on the legs of the host.

\section{Laboulbenia elaphri}

Laboulbenia elaphri Spegazzini 1915b:464. - Laboulbenia baenningeri Baumgartner 1951:XXXII. - Laboulbenia buehlmannii Poelt 1952b:116. Synonymy according to Banhegyi 1964.

$$
\text { - Figs. 72, 103, } 148 \text { (map). }
$$

Siemaszko \& Siemaszko (1928) described Laboulbenia elaphricola from Poland on Elaphrus riparius Linnaeus, but according to Banhegyi (1964), their species is either $L$. vulgaris or L. polyphaga.

The fungus found by Rostrup (1916) on Elaphrus cupreus Duftschmid in Denmark, although not determined to specific level, is presumably $L$. elaphri.

Material examined

Finland. Al: Sund. - Ab: Turku. Sammatti. Lohja. - Ta: Hattula. Pälkäne. - Le: Enontekiö, Hetta. All records on Elaphrus cupreus.

General distribution

Belgium (Spegazzini 1915b), Denmark (cf. Rostrup 1916), Federal Republic of Germany (Baumgartner 1951), Finland, France (Balazuc 1973-74), Hungary (Banhegyi 1964), Poland (Majewski 1971)

Host

Elaphrus cupreus and E. riparius (Coleoptera, Carabidae). The parasite occurs on various parts of the host, but most typically on the right side of the pronotum (Fig. 103).

Laboulbenia fasciculata

Laboulbenia fasciculata Peyritsch 1873:248. - Laboulbenia brachiata Thaxter 1890:11. — Figs. 90 a-b, 149 a-d (maps).

The main host in Finland is Patrobus atrorufus (Ström). The distribution of Laboulbenia fasciculata coincides with that of the host in southern Finland, where $P$. atrorufus is common. The parasite is missing farther north, where there are only scattered records of $P$. atrorufus (Fig. 149a). P. assimilis Chaudoir and $P$. septentrionis Dejean, which are common in northern Finland, are infested by $L$. fasciculata only in southern Finland (Figs. 149 b-c). Lindroth (1945) writes that $P$. atrorufus is mainly a larval hibernator, but this apparently not quite adequate. It most probably overwinters first as a larva and then as an imago, the life cycle taking two years. There must be some essential differences in the life cycles of the other $\mathrm{Pa}$ trobus species, as the parasite occurs on them only within the range of $P$. atrorufus (Figs. $149 \mathrm{a}-\mathrm{d}$ ). 
- Ab: Lohja. Karjalohja (Patrobus atrorufus, P. assimilis). Turku, Ruissalo. - N: Sjundeå. Espoo. Vantaa (P. atrorufus, $P$. assimilis). Helsinki ( $P$. atrorufus, $P$. assimilis, $P$. australis). - Ka: Anjalankoski. - St: Pori, mainland and Reposaari. - Ta: Sahalahti. Hattula. Tampere. Pirkkala $(P$. australis). Ruovesi. Kalvola. Janakkala (P. septentrionis). Sa: Lappeenranta. - Oa: Ilmajoki. When not otherwise indicated, the only host is $P$. atrorufus.

U.S.S.R. Leningrad Region: Molodežnoe (Vammeljoki) ( $P$. atrorufus). Priozersk (Käkisalmi) ( $P$. atrorufus). - Karelian A.S.S.R.: Sortavala (P. atrorufus, $P$. australis).

\section{General distribution}

Holarctic (Thaxter 1908, Sugiyama 1973, Balazuc 1973). In Europe known from Austria (Peyritsch 1873), the Federal Republic of Germany (Scheloske 1969), Finland, France (Balazuc 1973-74), Greece (Scheloske 1969), Hungary (Banhegyi 1969), Italy (Colla 1934), Poland (Siemaszko \& Siemaszko 1928), Romania (Balazuc 1973), Switzerland (Baumgartner 1923), the United Kingdom (Bisby \& Mason 1940), the U.S.S.R. (Leningrad Region; Karelian A.S.S.R.; Estonian S.S.R.: Siemaszko \& Siemaszko 1928; Latvian S.S.R.: Briedis 1932).

\section{Host}

Genera of Patrobus, Omophron, Pterostichus, Agonum, Chlaenius, Brachinus and Bembidion (Coleoptera, Carabidae). The parasite may occur anywhere on the host.

Laboulbenia fennica Huldén n.sp. - Figs. 97 a-c, h-i, 108, 150 (map).

Olivaceo-brunneus. Pedunculus cellulis I-II confectus geniculatus, 140-165 $\mu \mathrm{m}$ longus. Appendix penicillum compactum, circiter $60 \mu \mathrm{m}$ longum formans. Perithecium $60 \times 140-165 \mu \mathrm{m}$, in apice processus exiguos ferens. Sporae $5 \times 60-70 \mu \mathrm{m}$. Tota longitudo 320-420 $\mu \mathrm{m}$. Matrix principalis: Gyrinus aeratus Stephens (Coleoptera, Gyrinidae).

Receptacle. Olivaceous brown, cells I-II paler, upwards becoming nearly opaque. Cells I-II forming a geniculate stalk $140-165 \mu \mathrm{m}$ in length, broadening uniformly upwards from $18 \mu \mathrm{m}$ to $42 \mu \mathrm{m}$ in width. Cells I and II about equal in length. Cell III twice as long as cell IV. Cell VI about equal in length to cell III. Septa between cells III-IV and VI-VII directed obliquely downwards from the middle of receptacle.

Appendage. Branches of appendage forming a rather dense and compact brush, about $60 \mu \mathrm{m}$ in length. The cells of the branches nearly hyaline, but the septa opaque. Insertion cell completely dark and opaque.

Perithecium. Dark olivaceous brown, nearly opaque, tip pale with black spots on lip cells, the outgrowths as in Fig. $97 \mathrm{~b}-\mathrm{c}$. Size $60 \times 140-165 \mu \mathrm{m}$. Spores $5 \times 60-70 \mu \mathrm{m}$.

Total length from base of foot to tip of perithecium $320-420 \mu \mathrm{m}$.

Host. Gyrinus aeratus Stephens, G. distinctus Aubé, G. marinus Gyllenhal, G. minutus Fabricius, G. natator (Linnaeus), G. paykulli Ochs, G. pullatus Zaitzev and G. substriatus Stephens (Coleoptera, Gyrinidae). The parasite occurs on the outer margins of the elytra and the pronotum, accidentally on abdomen of the host.

Holotype. Slide L. Huldén 7, in MZH. Collecting data of the host: (Gyrinus aeratus) Finland. N: Hyvinkää (the Kerava river), 11.VII.1982, leg. P. Hiilivirta.

Balazuc (1971) reviewed all the European and North American species of Laboulbenia on the Gyrinidae and placed all European taxa and records under L. gyrinicola Spegazzini (as synonymes or forms). The specimen illustrated by Siemaszko \& Siemaszko (1933, Figs. 9 a-b), however, very probably represents L. fennica. It was recorded from Spain (Baleares) on Gyrinus urinator Degeer and was suspected by Siemaszkoś to be a new undescribed species. L. fennica differs very distinctly from the European $L$. gyrinicola in the general appearance (strongly geniculate and sigmoid-shaped in L. fennica), the shape of the outgrowths of the perithecium (Figs. $97 \mathrm{~b}-\mathrm{c}$ and d) and the more compact brush formed by the appendage branchlets. The new species is most closely related to the American L. funeralis Thaxter, but differs in the shape of the outgrowths of the perithecium (cf. Balazuc 1971, Fig. 3). Immature specimens of $L$. fennica can be separated from $L$. gyrinicola on cell III, which is about twice as big as cell IV (in L. gyrinicola about the same size), and on the rather narrow brush of appendage branchlets (more spreading in L. gyrinicola). The main host in Finland is Gyrinus aeratus (and possibly $G$. minutus), the other species being only accidental hosts, often within populations of $G$. aeratus. The host prefers lotic habitats. L. fennica seems to be restricted to South Finland, although the host is common northwards to the timber line (Huldén 1983). The explanation for this could be some difference in the life cycle pattern of the host in northern Finland, possibly hibernation in the larval stage.

\section{Material examined}

Finland. Ab: Perniö (G. aeratus, G. minutus). - N: Helsinki (G. minutus). Sjundeå (G. marinus). Sibbo (G. natator). Hyvinkää (G. aeratus, G. minutus, G. marinus, G. substriatus, $G$. nator). Ruotsinpyhtää ( $G$. aeratus, G. marinus, G. substriatus, $G$. distinctus). Pyhtää ( $G$. aeratus, $G$. marinus, $G$. distinctus). - Ka: Vehkalahti (G. aeratus, G. marinus, G. distinctus, G. paykulli, G.natator). - Ta: Tampere (G. pullatus). Kangasala (G. minutus). Pirkkala (G. minutus, G. paykulli). - Sb: Kuopio (G. aeratus).

\section{Laboulbenia filifera \\ Laboulbenia filifera Thaxter 1893:165.}

— Figs. 95, 151 (map).

The Fennoscandian material of $L$. filifera is similar to the illustrations given by Spegazzini (1914, Figs. 37 a-c). Both differ from the American specimens (Thaxter 1896, Figs. XIV: 19-20), however, which have a straight perithecium. Dr. I. Tavares kindly called my attention to this difference, which may indicate the existence of different taxa. I think it is best to place the material under L. filifera until more investigations have been made.

A collection from Argentina (Spegazzini 1912) was later described as a separate species, L. stolonicola (Spegazzini 1917). 
Material examined

Finland. Ab: Turku. - N: Helsinki. Pernå. - St: Tyrvää. Huittinen. - Sa: Mikkeli. Ruokolahti. Joutseno. - Tb: Viitasaari. On Harpalus affinis.

U.S.S.R. Leningrad Region: Uslanka. On H. affinis.

\section{General distribution}

Federal Republic of Germany (Scheloske 1969), Finland, Hungary (Banhegyi 1949), Italy (Colla 1934), Japan (Sugiyama 1973), Netherlands (Middelhoek 1949), Poland (Siemaszko \& Siemaszko 1928), Romania (Balazuc 1973), Switzerland (Baumgartner 1923), U.S.A. (Thaxter 1896), U.S.S.R. (Leningrad Region; Latvian S.S.R.: Briedis 1932; Buryat A.S.S.R., Selenga: Thaxter 1908).

\section{Host}

Genera of Harpalus, Anisodactylus, Stolonis, Trichotichnus, Badister, Pterostichus (Coleoptera, Carabidae). Most common on Harpalus affinis (Schrank) (H. aeneus Fabricius). The parasite may be found on various parts of the host.

\section{Laboulbenia flagellata}

Laboulbenia flagellata Peyritsch 1873:247. — Laboulbenia anceps Peyritsch 1873:247. - Laboulbenia elongata Thaxter 1890:10. - Laboulbenia gigantea Istvanffi 1895:82.

$$
\text { - Figs. } 89 \text { a-c, } 101 \text { a-b, } 152 \text { (map). }
$$

This species can be found on various parts of the host. On Agonum viduum (Panzer), however, it seems to be restricted to the ventral side of the right posterior corner of the pronotum and the area between the fore coxae, occurring only accidentally on other parts of the body (Fig. 101a). Interestingly, a parasitic mite often occurs in the same position as the fungus, but on the left side as well (Figs. $101 \mathrm{~b}-\mathrm{d}$ ).

\section{Material examined}

Finland. Al: Eckerö (Agonum viduum, A. gracile, A. dorsale). Finström (A. fuliginosum). Mariehamn (A. dorsale). Lemland $(A$. dorsale). Sottunga $(A$. dorsale $)$. $-\mathrm{Ab}$ : Lohja $(A$. thoreyi, $A$. dolens). Karjalohja (A. versutum). $-\mathrm{N}$ : Tuusula (A. viduum). - Ta: Asikkala (A. viduum). - Sa: Sääminki (A. viduum). - Sb: Siilinjärvi (A. thoreyi). Kuopio (A. fuliginosum). Joroinen (A. viduum). Leppävirta (A. viduum). Ok: Kajaani (Patrobus septentrionis).

U.S.S.R. Leningrad Region: Zelenogorsk (Terijoki) ( $A$. marginatum).

\section{General distribution}

Nearly cosmopolitan (Scheloske 1969). In Europe known from Belgium (Collart 1945), the Federal Republic of Germany (Scheloske 1969), Finland, France (Balazuc 197374), Hungary (Istvanffi 1895), Italy (Colla 1934), the Netherlands (Middelhoek 1949), Poland (Siemaszko \& Siemaszko 1928), Romania (Balazuc 1973), Spain (Balazuc et al. 1982), Switzerland (Baumgartner 1923), the U.S.S.R. (Leningrad Region; Latvian S.S.R.: Briedis 1932), the United Kingdom (Bisby \& Mason 1940), Yugoslavia (Siemaszko \& Siemaszko 1928).

\section{Host}

Genera of Agonum and Colpodes (Coleoptera, Carabidae). Some other genera are probably accidental hosts: Amara, Patrobus, Pterostichus, etc. Scheloske (1969) suspects that many records on alien hosts belong to other species than Laboulbenia flagellata.

\section{Laboulbenia giardii}

Laboulbenia giardii Cépède \& Picard 1909:258. - Figs. 82 a-b, 153 (map).
My material from Eastern Fennoscandia is similar to the illustration in the original description, but rather different from the illustrations given by Balazuc (1973-74) and Colla (1934), which have shorter and broader perithecia. The species possibly occurs in different forms.

\section{Material examined}

Finland. N: Espoo. Vantaa. Helsinki. - Ta: Tampere. - Sa: Joutseno. On Dicheirotrichus rufithorax.

U.S.S.R. Karelian A.S.S.R.: Sortavala (D. rufithorax).

\section{General distribution}

Finland, France (Cépède \& Picard 1909), 'Germania' (Spegazzini 1915a), Hungary (Banhegyi 1940), Italy (Spegazzini 1914), United Kingdom (Hinks 1960), U.S.S.R. (Karelian A.S.S.R.; Tomsk Region: Siemaszko \& Siemaszko 1932).

\section{Host}

Dicheirotrichus spp. (Coleoptera, Carabidae). The parasite occurs all over the host, most often on the elytra.

\section{Laboulbenia gyrinicola \\ Laboulbenia gyrinicola Spegazzini 1914:34.}

$$
\text { - Figs. } 97 \text { d-g. }
$$

This species has not been found in Eastern Fennoscandia, but is illustrated to indicate the differences from L. fennica. For comments, see Laboulbenia fennica.

\section{Material examined}

Sweden. Gotland: Visby (Gyrinus substriatus).

Czechoslovakia. Průhonice (G. substriatus).

\section{General distribution}

Compiled from Balazuc (1971): Algeria, Belgium, Czechoslovakia, France, Hungary, Italia, Poland, Romania, Sweden, Switzerland and Yugoslavia (my own material included). A record from Spain (Siemaszko \& Siemaszko 1933) very probably belongs to $L$. fennica. The record from United Kingdom (Thaxter 1908) resembles L. fennica, according to Dr. I. Tavares (pers. comm.).

\section{Host}

The genera of Gyrinus and Aulonogyrus (Coleoptera, Gyrinidae). The main host is probably G. substriatus Stephens. The parasite occurs on the lateral sides of the host.

\section{Laboulbenia hastiana Huldén n.sp.} - Figs. 96 a-c, 154 (map).

Fuscus. Pedunculus cellulis I-II confectus brevis, sursum valde dilatatus, 72-77 $\mu \mathrm{m}$ longus. Cellula VI perplanata. Appendix exterior robusta, ex cellula II vel III valde paniculata. Appendix interior exigua. Cellula insertionis et perithecium latitudine aequalia. Perithecium $35 \times 85 \mu \mathrm{m}$. Sporae $5 \times 40 \mu \mathrm{m}$. Tota longitudo circiter $165 \mu \mathrm{m}$. Matrix: Bembidion hasti Sahlberg (Coleoptera, Carabidae).

Receptacle. Dark brown, basally paler. Cells I-II forming a short stalk broadening strongly upwards, $72-77 \mu \mathrm{m}$ in length. Cell I narrow, $12-18 \mu \mathrm{m}$ wide, cell II about as broad as long, about $35 \mu \mathrm{m}$ wide. Cells III and IV about equal in size, cell V large and rounded but not connected with cell III. Cell VI much shorter than broad, about (30-) $24 \times 9 \mu \mathrm{m}$. 
Appendages. Insertion cell very broad, lower part externally blackish brown. Outer appendage with two or three basal cells very large and stout, sometimes as big as cells III and IV; from second or third cell with dense branches forming a nearly isodiametric brush. Inner appendage with basal cell very small and immediately giving rise to a brush of $8-10$ branchlets, presumably terminating in one antheridium each. The inner appendage just reaching the tip of perithecium. The second cell of outer appendage often reaching beyond the tip of perithecium. Inner appendage $47-60 \mu \mathrm{m}$; outer appendage $95-155 \mu \mathrm{m}$.

Perithecium. Dark brown, with black spots on lip cells, hyaline at the tip. Stout and straight or slightly inwards curved. Size about $35 \times 85 \mu \mathrm{m}$. Tip very broad and blunt. Spores $5 \times 40 \mu \mathrm{m}$.

Total length from base of foot to tip of perithecium about $165 \mu \mathrm{m}$.

Host. Bembidion hasti Sahlberg (Coleoptera, Carabidae). On elytra of the host.

Holotype. Slide L. Huldén 6, in MZH. Collecting data of the host: Finland. Om: Raahe, leg. Wuorentaus.

L. hastiana greatly resembles $L$. geodromici Baumgartner (1923), which, however, occurs on Psephidonus (Geodromicus) spp. (Coleoptera, Staphylinidae). In L. hastiana cell IV is about as broad as the perithecium, while in L. geodromici the perithecium is distinctly broader. L. hastiana is also somewhat more strongly pigmented than $L$. geodromici. In L. hastiana the branches of the inner appendage reach the tip of the perithecium, while in L. geodromici they are shorter. I have immature specimens of $L$. geodromici from Psephidonus nigrita (Müller) (collected in the Alps) and they seem to have thinner walls than L. hastiana. Material examined

See the type.

Laboulbenia kajanensis Huldén n.sp. - Figs. 98 a-b, 155 (map).

Receptaculum subflavidum, perithecium griseolo-brunneum. Pedunculus cellulis I-II confectus $155 \mu \mathrm{m}$ longus. Cellula $V$ perexigua, angusta. Cellula insertionis prope basin perithecii. Appendices non-paniculatae. Appendices et perithecium dextro-rotata. Perithecium introrsum flexum, magnitudine $42 \times 105 \mu \mathrm{m}$. Sporae 5 $\times 50 \mu \mathrm{m}$. Tota longitudo $275 \mu \mathrm{m}$. Matrix: Pterostichus diligens (Sturm) (Coleoptera, Carabidae).

Receptacle. Pale yellowish, cell I faintly darkened at the base, cells III and IV with brownish shade. Cells I-II forming a rather robust stalk, about 155 $\mu \mathrm{m}$ long and about $35 \mu \mathrm{m}$ wide in the upper part; cell I $70 \mu \mathrm{m}$ long. Cells III-IV about $40 \mu \mathrm{m}$ long, cell III smaller than cell IV. Cell V very small and narrow, not connected with cell III. Cell III slightly larger than cell VI.

Appendages. Insertion cell slightly narrower than cell IV, externally dark brown. Outer appendage consisting of row of seven unbranched cells, of nearly uniform width, tapering slightly towards tip, yellowish brown. Basal cells somewhat shorter than distal ones. Inner appendage consisting of row of five unbranched cells, the basal cell small, the four following longer and equal in length. One antheridium visible on fourth cell. Length of outer appendage 110-120 $\mu \mathrm{m}$, inner appendage about $55 \mu \mathrm{m}$. The appendages and the perithecium dextro-rotated.

Perithecium. Greyish brown, dark below the tip, tip nearly hyaline. The perithecium slightly bent inwards, dextro-rotated with the appendages, about $4 / 5$ free. Width $42 \times 105 \mu \mathrm{m}$. Spores about $5 \times 50 \mu \mathrm{m}$.

Total length from base of foot to tip of perithecium $275 \mu \mathrm{m}$.

Host. Pterostichus diligens (Sturm) (Coleoptera, Carabidae). The parasite was found on the left side of the prothorax.

Holotype. Slide L. Huldén 3, in MZH. Collecting data of the host: Finland. Ok: Paltamo, 23.V.1949, leg. Hellman.

The new species resembles somewhat $L$. contorta Thaxter (illustrated in Thaxter 1896), which was described from Agonum harrisi Leconte (affine auct.) and A. extensicolle Say in the U.S.A. L. kajanensis differs from $L$. contorta in the shape of the apex of the perithecium and in having cell $\mathrm{V}$ free from cell III. The inner appendage is shorter than the perithecium in $L$. kajanensis but longer in $L$. contorta. In the specimen in Fig. 88b cell IV has an additional division. Note also that the spiral turns in the opposite direction in the two species.

Material examined

See the type.

Laboulbenia leisti

Laboulbenia leisti Siemaszko \& Siemaszko 1928:203. - Figs. 84, 156 (map).

According to Scheloske (1969), intermediate forms between L. leisti and L. flagellata occur on Agonum spp. In Finnish specimens of $L$. flagellata the receptacle is more strongly pigmented, the perithecium more bluntly pointed and the appendages are more strongly branched than in L. leisti.

Material examined

Finland. Al: Jomala. Sottunga. On Leistus ferrugineus.

General distribution

Federal Republic of Germany (Scheloske 1969), Finland, France (Balazuc 1973-74), Hungary (Banhegyi 1949), Poland (Siemaszko \& Siemaszko 1928).

Host

Leistus spp. (Coleoptera, Carabidae). The parasite occurs mainly on the elytra of the host.

Laboulbenia manubriolata

Laboulbenia manubriolata Thaxter 1915:44. - Figs. 87 a-c, 157 (map).

This species was described by Thaxter from Java and Ceylon, growing on a carabid allied to Tachys. However, it was never illustrated by him in his monographs. Rossi (1982b) published the first picture of $L$. manubriolata, found on Perigona nigriceps (Dejean) (Coleoptera, Carabidae) from China. According to Rossi, the host of Thaxter's L. manubriolata very probably also belongs to Perigona nigriceps. $P$. nigriceps 
has only recently reached Finland as a result of human activity ( $O$. Biström pers. comm.) and possibly there are now a few permanent populations in southern Finland.

The material of Laboulbenia manubriolata from Finland is very uniform except for some specimens from the legs which are very short, about $125 \mu \mathrm{m}$ in length (Fig. 87c), with a more robust appearance and more strongly pigmented thallus. The stalk cells of the receptacle are very short and cells I-II of equal length.

\section{Material examined}

Finland. N: Helsinki (Perigona nigriceps).

\section{General distribution}

China (Rossi 1982b), Finland, Indonesia (Java: Thaxter 1915), Sri Lanka (Thaxter 1915)

\section{Host}

Perigona nigriceps (Coleoptera, Carabidae). The parasite may grow anywhere on the host.

\section{Laboulbenia metableti}

Laboulbenia metableti Scheloske 1969:124. - Figs. 74 a-b, 158 (map).

This species is relatively easy to recognize by the shape of the perithecium and the structure of the appendages. The outer appendage may grow to a length of at least $400 \mu \mathrm{m}$ (according to Scheloske $300 \mu$ ).

Material examined

Finland. Al: Föglö. Eckerö. Lemland. - Ab: Korpo. - N: Helsinki. - Ka: Miehikkälä. - Sa: Rantasalmi. Lappeenranta. - Oa: Ilmajoki. - Kb: Eno. All records on Syntomus truncatellus.

U.S.S.R. Leningrad Region: Rjabino (Kuolemajärvi). Zelenogorsk (Terijoki). Gumbaritsa. Vaašeni. - Karelian A.S.S.R.: Sortavala. On S. truncatellus.

General distribution

Federal Republic of Germany (Scheloske 1969), Finland, Italy (Rossi \& Cesari 1976), Poland (Majewski 1971), U.S.S.R. (Leningrad Region; Karelian A.S.S.R.).

\section{Host}

Syntomus (Metabletus) foveatus Geoffroy, S. obscuroguttatus (Duftschmid) and S. truncatellus (Linnaeus) (Coleoptera, Carabidae). The parasite may occur anywhere on the host.

Laboulbenia murmanica Huldén n.sp.

$$
\text { - Figs. 80, } 159 \text { (map). }
$$

Receptaculum brunneum, perithecium fuscum. Pedunculus cellulis I-II confectus curvatus, 120-165 $4 \mathrm{~m}$ longus. Cellula insertionis latiuscula, juxta basin perithecii sita. Appendix perithecio brevior. Margo interior perithecii valde turgidus, margo exterior directus. Perithecium 55-65 X $120 \mu \mathrm{m}$. Sporae 4-5 × 35-42 $\mu \mathrm{m}$. Tota longitudo $275 \mu \mathrm{m}$. Matrix: Bembidion transparens (Gebler) (Coleoptera, Carabidae).

Receptacle. Brown, paler near the base, cells I-VI with rather densely but irregularly distributed dark spots, which grow stronger upwards. Cells I-II forming a strongly curved stalk, $120-165 \mu \mathrm{m}$ long, whose width increases uniformly upwards, from 12 $\mu \mathrm{m}$ to $35 \mu \mathrm{m}$. Cell I and II about equal in length, cell III slightly larger than cell IV. Cell V rather large and isodiametric.
Appendages. Insertion cell rather broad, the lower part externally dark brown, situated close to the base of perithecium. Basal cell of outer appendage rather large, the second cell slightly smaller and tapering strongly at the upper end. From the second cell arise one or two rows of cells, forming narrow branches, which apparently are very short, not reaching the tip of the perithecium, but are so fragile that their exact structure cannot be discerned. The basal cells of the two inner appendages are equal in width to the outer one, but only half as long. The second cell is equal in size to the basal cell but tapers slightly. From the second cell arise two short narrow branchlets, each ending in an antheridium. The two inner appendages are situated symmetrically on both sides of the outer appendage. Length of inner appendage, $42-48 \mu \mathrm{m}$.

Perithecium. Uniformly dark brown, pale near the tip. Inner margin strongly inflated, outer margin nearly straight. Nearly whole perithecium free. Size, $55-65 \times 120 \mu \mathrm{m}$. Spores $4-5 \times 35-42 \mu \mathrm{m}$.

Total length from base of foot to tip of perithecium about $275 \mu \mathrm{m}$.

Host. Bembidion transparens (Gebler) (Coleoptera, Carabidae). The parasite was found on the right elytron of the host.

Hototype. Slide L. Huldén 4, in $\mathrm{MZH}$. Collecting data of the host: U.S.S.R. Murmansk Region: Konozero, leg. Edgren.

\section{Material examined}

See the type.

Laboulbenia notiophili

Laboulbenia notiophili Cépède \& Picard 1909:259. — Figs. 85 a-b, 160 (map).

\section{Material examined}

Finland. Al: Lemland (Notiophilus germinyi). Ab: Lohja ( $N$. biguttatus). - N: Espoo ( $N$. biguttatus). Vantaa ( $N$. biguttatus). Helsinki ( $N$. biguttatus). Sibbo (N. biguttatus). - Ta: Lammi (N. biguttatus). — Ok: Kajaani (N. germinyi).

\section{General distribution}

Federal Republic of Germany (Scheloske 1969), Finland, France (Cépède \& Picard 1909), Hungary (Banhegyi 1940), Poland (Siemaszko \& Siemaszko 1928), Spain (Balazuc et al.1982), Switzerland (Baumgartner 1923).

\section{Host}

Notiophilus spp. (Coleoptera, Carabidae). The parasite occurs on various parts of the host.

Laboulbenia oodiphila Huldén n.sp. - Figs. 93 a-b, 161 (map).

Receptaculum brunnescenti-flavum, perithecium fuscum. Pedunculus cellulis I-II confectus satis robustus, 300-380 um longus. Cellula insertionis juxta basin perithecii. Appendices dichotome paniculatae, hyalinae, fragiles. Perithecium $65 \times 190 \mu \mathrm{m}$. Sporae $5 \times 55 \mu \mathrm{m}$. Tota longitudo 600-770 $\mu \mathrm{m}$. Matrix: Oodes helopioides (Fabricius) (Coleoptera, Carabidae).

Receptacle. Brownish yellow, with faint dots, darkening with age. Cells I-II forming a rather robust stalk, about $40 \mu \mathrm{m}$ wide and $300-380 \mu \mathrm{m}$ long. Cell I tapering towards foot. Cells III-IV about $120 \mu \mathrm{m}$ 
long, cell IV about half the size of cell III. Cell VI slightly shorter than cell III. Cell V narrow, triangular.

Appendages. Insertion cell externally dark brown, situated near base of perithecium. Basal cell of outer appendage longer than that of inner appendage. Outer appendage $0-2$ times dichotomously branched. Inner appendage 3-4 times dichotomously branched, antheridia $1-2$ at base of lower branches, or at apex of shorter branches. Both appendages very hyaline and fragile and soon disintegrating.

Perithecium. Uniformly dark brown, slightly paler near the tip, with blackish brown spots on lip cells; darkening with age. Nearly whole perithecium free. Regular or slightly outwards bent. Size of perithecium $65-190 \mu \mathrm{m}$. Spores $5 \times 55 \mu \mathrm{m}$.

Total length from base of foot to tip of perithecium $600-700 \mu \mathrm{m}$.

Host. Oodes helopioides (Fabricius) (Coleoptera, Carabidae). The parasite occurs on the anterior margin of the left elytron and the left mesofemur, accidentally on the coxae or other parts of the elytra.

Holotype. Slide L. Huldén 5, in MZH. Collecting data of the host: Finland. Al: Finström, 30.VI.1943, leg. Håkan Lindberg.

Closely related to L. dailodonti Spegazzini (1912), described from Argentina on Polystichus (Dailodontus) clandestinus (Klug) (Coleoptera, Carabidae). L. oodiphila is separated from that species mainly on cell III, which is about as long as cell VI (in L. dailodonti cell III nearly twice as long as cell VI). L. oodiphila is also more strongly pigmented than $L$. dailodonti. Baumgartner (1923) reported $L$. dailodonti from Switzerland on Oodes helopioides. This record apparently concerns L. oodiphila. Another species, L. paludosa Picard, also occurs on Oodes helopioides (Balazuc $1973-74)$, but it is much smaller $(260-270 \mu \mathrm{m})$ than $L$. oodiphila and the lip cells of the perithecium are quite different.

Material examined

Finland. Al: Finström. - Ab: Lohja. On Oodes helopioides.

Laboulbenia ophoni

Laboulbenia ophoni Thaxter 1899:190. - Figs. 75, 162 (map).

\section{Material examined}

Finland. Al: Jomala (Harpalus xanthopus winkleri). - N: Ekenäs (H. tardus). - Ta: Hattula (H. luteicornis).

U.S.S.R. Leningrad Region: Vesnino (Pyhäjärvi) (H. latus). Hiitola (H. luteicornis). Uslanka (H. tardus).

\section{General distribution}

Algeria (Thaxter 1899), Federal Republic of Germany (Scheloske 1969), Finland, France (Picard 1914), Hungary (Banhegyi 1949), Italy (Spegazzini 1914), Poland (Siemaszko \& Siemaszko 1928), Spain (Balazuc et al.1982), Switzerland (Baumgartner 1923), U.S.S.R. (Leningrad Region; Vologda Region: Siemaszko \& Siemaszko 1928; 'Caucasus': Siemaszko \& Siemaszko 1928).

\section{Host}

Harpalus spp., Carterus fulvipes (Latreille) (Coleoptera, Carabidae). The parasite occurs on various parts of the host.
Laboulbenia pedicellata

Laboulbenia pedicellata Thaxter 1892:44. - Laboulbenia gracilipes Cépède \& Picard 1908:780. Synonymy according to Scheloske 1969.

$$
\text { - Figs. } 77 \text { a-e, } 163 \text { (map). }
$$

Under this species I am placing varying forms, as indicated by Figs. 77 a-e. The specimens in Figs. 77 a-b closely resemble $L$. bembidiopalpi, described from America (Benjamin \& Shanor 1952). The Fennoscandian material also contains a series of forms intermediate between this and the long form in Fig. 77d (even within a brush of specimens from the same position on the leg of a host). The last-mentioned form could be called the typical $L$. pedicellata. Many specimens on Dyschirius spp. (Fig. 77e) resemble L. gracilipes Cépède \& Picard, which was synonymized with $L$. pedicellata by Scheloske (1969). In my opinion, $L$. pedicellata is a polymorphic species, which, in addition to L. gracilipes, may include L. bembidiopalpi and tapirina, described from North America (Benjamin \& Shanor 1952).

In the typical long forms, cell II is constricted in its upper part and distinctly paler, in the shorter forms this constriction is absent and the pigmentation is more evenly distributed. The septum between cells IV and $\mathrm{V}$ is either vertical or slightly oblique.

The main host in Eastern Fennoscandia is Dyschirius globosus.

\section{Material examined}

Finland. Al: Föglö. Jomala. Hammarland. - Ab: Lohja (Dyschirius globosus, Bembidion articulatum). Pargas (B. gilvipes). Korpo, Jurmo. Turku. - N: Hangö, Tvärminne. Sibbo. Espoo. Helsinki (D. globosus, B. quadrimaculatum). Pornainen. - St: Rauma. - Ta: Tampere. Pälkäne. - Sa Mikkeli. - Tb: Nilsiä (B. doris). Suonenjoki. Vehmersalmi. Iisalmi. - Kb: Kontiolahti. - Om: Revonlahti. Haapavesi. - Ks: Salla (D. septentrionum). - Om: Rovaniemi. When not otherwise indicated, the only host species is Dyschirius globosus.

U.S.S.R. Leningrad Region: Iskra (Muolaa) (D. globosus). Rjabino (Kuolemajärvi) (D. globosus, D. septentrionum) Molodežnoe (Vammeljoki) (D. arenosus, B. semipunctatum). Poljany (Uusikirkko) (D. arenosus, B. ruficolle). - Karelian A.S.S.R.: Oz. Olanga (Paanajärvi) (D. globosus). - Archangel Region: Solovetsk Islands (D. globosus).

\section{General distribution}

Apparently cosmopolitan. In Europe known from Belgium (Collart 1945), the Federal Republic of Germany (Scheloske 1969), Finland, France (Balazuc 1973-74), Greece (Siemaszko \& Siemaszko 1928), Hungary (Banhegyi 1944), Italy (Siemaszko \& Siemaszko 1928), the Netherlands (Middelhoek 1943a), Poland (Siemaszko \& Siemaszko 1928), Romania (Balazuc 1973), Spain (Balazuc et al.1982), the United Kingdom (Green 1954), the U.S.S.R. (Leningrad Region; Karelian A.S.S.R.; Archangel Region; Latvian S.S.R.: Briedis 1932).

\section{Host}

Dyschirius spp., Bembidion spp., Tachys spp. and some related genera (Coleoptera, Carabidae). The parasite occurs on various parts of the host.

Laboulbenia polyphaga

Laboulbenia polyphaga Thaxter 1893:165. - Figs. 73 a-b, 164 (map). 
This species resembles $L$. vulgaris, but differs in having the insertion cell closer to the base of the perithecium. The appendages are also more robust in $L$. vulgaris.

The main host of this species in Fennoscandia seem to be Bradycellus caucasicus Chaudoir (B. collaris Paykull) and Calathus melanocephalus (Linnaeus). The record on Trechus secalis is certainly an accidental one because this species is a larval hibernator in Fennoscandia (Lindroth 1945). It is interesting to note that Laboulbenia bradycelli has not been found on Bradycellus spp. in Eastern Fennoscandia, although this parasite-host combination is common in France (Balazuc 1973-74).

\section{Material examined}

Finland. Al: Lemland, Flaka (Calathus melanocephalus). Mariehamn (C. melanocephalus). Geta (C. melanocephalus). Finström (C. melanocephalus). - Ab: Uusikaupunki (Bradycellus ruficollis, B. caucasicus). Lohja (C. melanocephalus, $B$. caucasicus). Vihti (B. caucasicus). Turku (B. caucasicus). - N: Ekenäs (C. micropeterus). Hangö, Tvärminne ( $C$. melanocephalus, B. ruficollis, B. caucasicus). Helsinki (C. erratus, C. micropterus, C. melanocephalus, B. caucasicus). Espoo (B. caucasicus). Tuusula ( $B$. caucasicus). Sjundeå $(B$. caucasicus). - Ta: Hartola (B. caucasicus). Ylöjärvi (B. caucasicus). Pälkäne (B. caucasicus). Hattula (B. caucasicus). -Sa: Joutseno (B. caucasicus). Ristiina (Acupalpus flavicollis). - Sb: Vehmersalmi (B. caucasicus). - Kb: Kitee (B. caucasicus). - Ok: Ristijärvi (B. caucasicus). - Ks: Kuusamo (B. caucasicus).

U.S.S.R. Leningrad Region: Kamennogorsk (Antrea). Segeža. Uslanka. - Karelian A.S.S.R.: Sortavala. Pirknitsa. Ahvenjärvi. Kendjärvi. Semsjärvi. All records of B. caucasicus.

\section{General distribution}

Cosmopolitan (Scheloske 1969). In Europe known at least from Belgium (Collart 1945), the Federal Republic of Germany (Scheloske 1969), Finland, France (Balazuc 197374), Hungary (Banhegyi 1940), Italy (Colla 1934), the Netherlands (Middelhoek 1949), Poland (Siemaszko \& Siemaszko 1928), Portugal (Balazuc et al. 1982), Switzerland (Baumgartner 1923), U.S.S.R. (Leningrad Region; Latvian S.S.R.: Briedis 1932)

Host

A large number of genera, including Badister, Calathus, Acupalpus, Bradycellus, Pterostichus and Amara (Coleoptera, Carabidae). The parasite occurs on various parts of the host.

Laboulbenia pseudomasei Thaxter 1899:196. - Laboulbenia matheyi Baumgartner 1923:263, according to Scheloske 1969.

$$
\text { - Figs. } 91 \text { a-b, } 165 \text { (map). }
$$

According to Balazuc (1973-74) L. pseudomasei is a synonym of $L$. pterostichi Thaxter (1893). The Fennoscandian material resembles the illustrations of $L$. pseudomasei in Thaxter (1896) and Scheloske (1969), but not L. pterostichi as illustrated in Thaxter (1908). In the Federal Republic of Germany Scheloske (1969) found only L. pseudomasei and no forms resembling L. pterostichi, which he considered to be a separate species. As I am not acquainted with the total range of variation of $L$. pterostichi and L. pseudomasei, I have not accepted Balazuc's opinion. Fig. 81b represents in my opinion a fairly typical L. pseudomasei, while Fig. 81a shows a long striated form (found only once in the north on Pterostichus nigrita). However, the identity of the latter form remains uncertain.

\section{Material examined}

Finland. Al: Eckerö (Pterostichus nigrita). - Ab: Lohja ( $P$. nigrita, $P$. minor $)$. - N: Hangö, Tvärminne $(P$. minor, $P$. strenuus). Espoo (P. strenuus). - Sb: 'Sav.bor., Woldstedt', exact locality not known $(P$. nigrita). - Ok: Kajaani $(P$. nigrita). - Ob: Kempele ( $P$. nigrita). Liminka ( $P$. nigrita) -Ks: Kuusamo (P. nigrita, Patrobus septentrionis).

U.S.S.R. Karelian A.S.S.R.: Oz. Olanga (Paanajärvi). On Patrobus assimilis.

\section{General distribution}

Federal Republic of Germany (Scheloske 1969), Finland, France (Balazuc 1973-74), Hungary (Banhegyi 1949), Italy (Spegazzini 1914), Mongolia (Thaxter 1908), Poland (Siemaszko \& Siemaszko 1928), Switzerland (Baumgartner 1923), U.S.S.R. (Karelian A.S.S.R.).

Host

Pterostichus spp., Anisodactylus spp. and occasionally on some other related genera (Coleoptera, Carabidae). The parasite may occur anywhere on the host.

\section{Laboulbenia pterostichi}

Laboulbenia pterostichi Thaxter 1893:166. Illustrated in Thaxter 1896.

This species was not found during the present study. It was reported from Finland on Harpalus nigritarsis Sahlberg by Siemaszko \& Siemaszko (1928). According to Lindroth (cf. Arwidsson 1946) the host in question is probably $H$. solitaris Dejean $(H$. fuliginosus Duftschmid). This record remains obscure since the collection of the Siemaszko's was destroyed during World War II (Majewski 1971).

\section{General distribution}

Federal Republic of Germany (Stadelmann \& Poelt 1962), Finland (Siemaszko \& Siemaszko 1928), Hungary (Banhegyi 1949), Japan (Sugiyama 1973), Poland (Siemaszko \& Siemaszko 1928), Switzerland (Baumgartner 1923), Uruguay (Spegazzini 1917), U.S.A. (Thaxter 1893).

Host

Many genera, including Harpalus and Pterostichus (Coleoptera, Carabidae). The parasite occurs on various parts of the host (Thaxter 1896).

\section{Laboulbenia pulchella \\ Laboulbenia pulchella Spegazzini 1914:39.} - Figs. 79, 166 (map).

Colla (1934) thought that this species is a form of $L$. polyphaga, but the cells of $L$. pulchella are more inflated than in L. polyphaga. L. pulchella subsp. major, described from Austria on Syntomus (Metabletus) foveolatus Dejean by Spegazzini (1914), is possibly only a larger specimen of $L$. pulchella. The dark pigmentation on the outer part of cells III and IV (and upper region of II) seems to be very typical of $L$. pulchella.

Material examined

Finland. N: Espoo (Dromius linearis). 
General distribution

Austria (Spegazzini 1914), Finland, Italy (Spegazzini 1914).

Host

Dromius linearis (Olivier) and Syntomus (Metabletus) foveolatus (Coleoptera, Carabidae). The parasite occurs on various parts of the host.

\section{Laboulbenia stilicicola}

Laboulbenia stilicicola Spegazzini 1914:41. - Figs. 86, 167 (map).

The identity of the Finnish Laboulbenia material found on Rugilus (Stilicus) similis (Erichson) is somewhat unclear. It greatly resembles $L$. notiophili, which occurs on Notiophilus spp. (Coleoptera, Carabidae). The illustration (Fig. 86) represents an elongated form; shorter forms look like L. notiophili in Fig. 85b. L. stilicicola should have a much smaller and simple appendage and the perithecium should be narrower than in the Finnish material. The spores of the Finnish specimens are about $25 \mu \mathrm{m}$ long while those of $L$. notiophili are about $35 \mu \mathrm{m}$ (Finnish specimens measured). For the time being, I am placing this material under L. stilicicola.

\section{Material examined}

Finland. Sa: Ristiina. On Rugilus similis.

\section{General distribution}

Finland, France (Balazuc 1973-74), Italy (Spegazzini 1914), Netherlands (Middelhoek 1943a), Poland (Siemaszko \& Siemaszko 1932), Switzerland (Baumgartner 1923), United Kingdom (Thaxter 1908, as 'L. subterranea'), U.S.A. (Balazuc 1973-74)

Host

Rugilus (Stilicus) spp. (Coleoptera, Staphylinidae). The parasite occurs on various parts of the host.

\section{Laboulbenia vulgaris}

Laboulbenia vulgaris Peyritsch 1873:248. - Figs. 81 a-d, 168 (map).

Laboulbenia vulgaris is a very polymorphic species and presumably the most widely distributed species of the Laboulbeniales in the world. It has a broad ecological amplitude and reaches an altitude of at least 4200 m (in Mexico: Rossi \& Cesari Rossi 1977). Although the specimens from different hosts may differ from each other, these strains do not seem to be very host-specific. Different morphs may also be due to the position on the host (cf. Scheloske 1969). I am treating $L$. vulgaris in a broad sence and have not tried to separate the varieties described from different hosts.

The lack of records from central parts of Eastern Fennoscandia (see map in Fig. 168) is hard to explain, because many of the host species are common all over the area. There is a shift to other host species in the north: Bembidion hasti Sahlberg and B. difficile (Motschulsky). Trechus rubens (Fabricius) is common to both areas, wich may indicate that this is only an accidental host. The southern hosts possibly have a different life cycle from those in the north.

\section{Material examined}

Finland. Al: Jomala (Bembidion assimile). - Ab: Turku, Ruissalo (B. unicolor). Salo (B. bruxellense). Lohja (B. dentellum, $B$. biguttatum). Karjalohja ( $B$. saxatile). Ispoinen ( $B$. guttula). Kaarina (B. guttula). Uusikaupunki (Trechus rubens). - N: Ekenäs $(B$. tetracolum, $B$. unicolor $)$. Espoo ( $B$. bruxellense, $B$. unicolor). Vantaa ( $B$. tetracolum, $B$. bruxellense, $B$. guttula). Helsinki (B. tetracolum). Borgå (B. bruxellen$s e)$. Nurmijärvi (B. bruxellense). - St: Pori, mainland and Reposaari (B. tetracolum). - Ta: Pälkäne (B. guttula, B. unicolor). Hattula ( $B$. bruxellense). Orivesi (B. bruxellense). Tampere $(B$. dentellum $)$. Janakkala $(B$. dentellum $)$. $-\mathrm{Sa}$ : Ristiina (B. bruxellense). Luumäki (B. saxatile). - Tb: Viitasaari ( $B$. bruxellense). Virrat (B. bruxellense). - Sb: Kuopio (B. bruxellense, B. guttula).

U.S.S.R. Leningrad Region: Poljany (Uusikirkko) (B. bruxellense). Molodežnoe (Vammeljoki) (B. bruxellense). Gumbaritsa (B. unicolor). - Karelian A.S.S.R.: Salmi (B. bruxellense). - Murmansk Region: Pummanki (B. hasti). Kola (B. hasti). 'Kola, fl. Tuloma' (B. hasti). Ponoj (B. hasti). Pjalitsa (Trechus rubens). Zapoljarnyj (Yläluostari) (B. difficile).

General distribution

Cosmopolitan (Balazuc 1982). Evidently all over Europe.

Host

A large number of genera, including Bembidion, Trechus, Bradycellus, Dyschirius, Brachinus, Duvalius (Coleoptera, Carabidae). The parasite occurs on various parts of the host.

Misgomyces dyschirii

Misgomyces dyschirii Thaxter 1900:443. - Figs. 16, 169 (map).

Material examined

Finland. Al: Jomala (Dyschirius politus). Kökar (D. globos$u s)$. Föglö (D. globosus). - Ab: Korpo, Jurmo (D. globosus). Kimito (D. globosus). Lohja (D. globosus). - N: Hangö, Tvärminne (D. globosus). Ekenäs (D. globosus). Helsinki ( $D$. globosus). - St: Rauma (D. globosus). - Ta: Pälkäne (D. globosus).

U.S.S.R. Leningrad Region: Zaporožskoe (Metsäpirtti). Molodežnoe (Vammeljoki). Poljany (Uusikirkko). All records on D. septentrionum.

\section{General distribution}

Algeria (Maire 1916a), Federal Republic of Germany (Scheloske 1969), Finland, France (Balazuc 1973-74), Hungary (Banhegyi 1944), Italy (Rossi 1975), Japan (Sugiyama 1973), Netherlands (Middelhoek 1943a), Poland (Siemaszko \& Siemaszko 1928), Switzerland (Baumgartner 1923), United Kingdom (Bisby \& Mason 1940), U.S.A. (Thaxter 1900), U.S.S.R. (Leningrad Region).

\section{Host}

Dyschirius spp. (Coleoptera, Carabidae). The parasite may be found anywhere on the host but mainly on the pronotum and base of elytra.

Monoicomyces britannicus

Monoicomyces britannicus Thaxter 1900:413

- Figs. 23 a-b, 170 (map).

Material examined

Finland. Al: Finström. Eckerö. - Ab: Lohja. - N: Kyrkslätt. Helsinki. - Sa: Ristiina. - Ob: Rovaniemi, Pisavaara. All records on Atheta longicornis.

U.S.S.R. Leningrad Region: Vesnino (Pyhäjärvi). - Karelian A.S.S.R.: Sortavala. On $A$. longicornis. 
General distribution

Federal Republic of Germany (Scheloske 1969), Finland, France (Picard 1917), Italy (Spegazzini 1915c), Poland (Siemaszko \& Siemaszko 1932), United Kingdom (Thaxter 1908), U.S.S.R. (Leningrad Region; Karelian A.S.S.R.).

\section{Host}

Atheta insecta (Thomson), A. longicornis (Gravenhorst), other host records are uncertain (Coleoptera, Staphylinidae). The parasite occurs mainly on the abdomen of the host.

\section{Monoicomyces furcatus}

Monoicomyces furcatus Thaxter 1931:41 - Figs. 20 a-c, 104, 171 (map).

Not previously reported from Europe. The species is recognized by the furcate habit of the receptacle, shown in Fig. 20b. In Eastern Fennoscandia it seems to be confined to Oxytelus laqueatus (Marsham). Siemaszko \& Siemaszko (1932) reported Monoicomyces invisibilis as occurring on O. laqueatus in Poland, but their illustrations ( $6 \mathrm{a}$ and $6 \mathrm{~b}$ ) most probably represent $M$. furcatus. Their species is larger than $M$. invisibilis $(250-500 \mu \mathrm{m}$ vs. $110-140 \mu \mathrm{m})$ and furcate, and the host species is that of $M$. furcatus in Fennoscandia.

\section{Material examined}

Finland. Ab: Lohja. - St: Pori. - Ta: Loppi. Janakkala. -Sa: Ristiina. - Kl: Parikkala. - Sb: Joroinen. Kuopio. Iisalmi. - Kb: Kontiolahti, Liperi. Juuka. - Ob: Oulu. Rovaniemi, Pisavaara. - Le: Kilpisjärvi. All records on Oxytelus laqueatus.

U.S.S.R. Leningrad Region: Vesnino (Pyhäjärvi), - Karelian A.S.S.R.: Jänisjärvi. Jaakkima. Kiži. - Murmansk Region: Zapoljarnyj (Yläluostari). On O. laqueatus.

\section{General distribution}

Finland, Guatemala (Thaxter 1931), Haiti (Thaxter 1931), Jamaica (Thaxter 1931), Poland (Siemaszko \& Siemaszko 1932, as Monoicomyces invisibilis), U.S.S.R. (Leningrad Region, Karelian A.S.S.R.; Murmansk Region).

\section{Host}

Anotylus insignitus (Gravenhorst) in America, Oxytelus laqueatus in Europe (Coleoptera, Staphylinidae). The parasite occurs on various parts of the host, but most abundantly on the abdomen.

\section{Monoicomyces homalotae}

Monoicomyces homalotae Thaxter 1900:412.

- Figs. 24 a-c, 172 (map).

The Finnish specimens have a brownish constriction on the perithecial stalk cell, as illustrated by Thaxter (1908, Fig. XXXV:9). The normal form lacks this character (Fig. XXXV:8, in Thaxter 1908).

\section{Material examined}

Finland. Al: Lemland. - N: Helsinki. Vantaa. - Ka: Virolahti. - Sb: Kuopio. On Atheta paracrassicornis Brundin.

\section{General distribution}

Algeria (Maire 1916a), Argentina (Spegazzini 1912), Azores (Thaxter 1908), Federal Republic of Germany (Poelt 1952a), Finland, Italy (Spegazzini 1915c), Japan (Sugiyama 1978c), Netherlands (Middelhoek 1943a), U.S.A. (Thaxter 1908).
Host

Atheta spp., Geostiba circellaris (Gravenhorst) (Coleoptera, Staphylinidae). The parasite was found on the last abdominal segment of the host (on Atheta paracrassicornis in Finland)

Monoicomyces invisibilis

Monoicomyces invisibilis Thaxter 1900:414. - Monoicomyces affinis Spegazzini 1915c:65. - Figs. 21 a-c, 173 (map).

Platystethys arenarius (Fourcroy) from which the Finnish record was made, may be an accidental host. The records from Poland (Siemaszko \& Siemaszko 1932) most probably concerns $M$. furcatus (see comments under that species).

Material examined

Finland. Al: Jomala. On Platystethus arenarius.

\section{General distribution}

Azores (Thaxter 1900), Finland, Indonesia (Sumatra: Thaxter 1931), Italy (Spegazzini 1915c), Venezuela (Thaxter 1931).

\section{Host}

Oxytelus spp., Platystethus arenarius (Coleoptera, Staphylinidae). The parasite occurs on the legs and abdomen of the host.

Monoicomyces oxytelis Huldén n.sp.

$$
\text { — Figs. } 22 \text { a-c, } 174 \text { (map). }
$$

Flavidus, hyalinus. Ex axe principali unus axis secundarius lateralis oritur. Axis secundarius ex cellulis (3-) 4-7 oblique connexis, angustis constat. Longitudo axis principalis $\times$ secundarii $85-110 \mu \mathrm{m}$. Axis secundarius singulum antheridium compositum fert. Pedunculus perithecii 40-65 $\mu \mathrm{m}$ longus. Perithecium regulare, infra

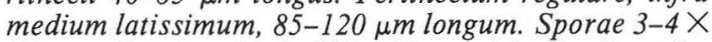
$33 \mu \mathrm{m}$. Tota longitudo 190-275 $\mu \mathrm{m}$. Matrix: Oxytelus fulvipes Erichson (Coleoptera, Staphylinidae).

Primary and secondary axis. Yellowish hyaline. Primary axis consisting of two superposed cells about equal in size, the basal cell somewhat inflated and the subbasal cell more elongated. Secondary axis consisting of (3-)4-7 obliquely connected cells. The cells are rather narrow, about $2-3$ times as long as wide. Length of primary and secondary axis $85-110 \mu \mathrm{m}$.

Appendages and antheridia. Primary axis terminating in one sterile appendage consisting of a basal cell tapering strongly apically and a long narrow branch about $120 \mu \mathrm{m}$ in length. Septum between the basal cell and its branch black. Cells of secondary axis with paired sterile appendages resembling that of primary axis, except for the last one which bears the compound antheridium. The compound antheridium terminating in four short appendages of varying length, at most $10 \mu \mathrm{m}$ long. Being fragile, the appendages are usually soon broken, the upper ones persiting longest.

Perithecium. Yellowish hyaline. The stalk consisting of one elongated cell, $40-65 \mu \mathrm{m}$ in length, arising from the last cell of the secondary axis. Perithecium very regular, broadest below the middle, tapering 
upwards to a neck. Size of perithecium $35-48 \times 85-$ $120 \mu \mathrm{m}$. Spores about $3-4 \times 33 \mu \mathrm{m}$.

Total length from base of foot to tip of perithecium $190-275 \mu \mathrm{m}$.

Host. Oxytelus fulvipes Erichson (Coleoptera, Staphylinidae). The parasite occurs all over the host.

Holotype. Slide L. Huldén 9, in MZH. Collecting data of the host. Finland. Ab: Karjalohja, 25.VI.1938, leg. O. Renkonen.

Monoicomyces oxytelis resembles $M$. invisibilis, but is separated on the cells of the secondary axis, which are more numerous and rather narrow. The new species seems to have a constant habit on Oxytelus fulvipes, known from three different localities in Finland.

\section{Material examined}

Finland. Al: Finström. - Ab: Lohja. Karjalohja.

\section{Monoicomyces sanctae-helenae}

Monoicomyces sanctae-helenae Thaxter 1900:413. Monoicomyces roccae Colla 1925:254, according to Colla 1934.

$$
\text { - Figs. } 25 \text { a-c, } 175 \text { (map). }
$$

The typical morph (Fig. 25c) of this species has five or three secondary axes, arising from the second cell of the primary axis, and each formed by four long cells. The other morph (figs. 25 a-b), described as M. roccae but synonymized with $M$. sanctae-helenae, has normally only one secondary axis (rarely two or three) consisting of six or seven rather short cells. In the material from the Leningrad Region both morphs occur together, in Finland only the latter morph and in the Novosibirsk Region the typical morph. No intermediate forms seem to occur, so that these may represent different species, but more material of the latter morph is required before they can be separated. Specimens from Taiwan (Sugiyama 1981) look rather strange, with blunt perithecia and many antheridia along the secondary axis; they possibly also represent a separate taxon.

\section{Material examined}

Finland. Sa: Ristiina. On Oxytelus piceus.

U.S.S.R. Leningrad Region: Zaporožskoe (Metsäpirtti). Novosibirsk Region: Karasuk. On $O$. piceus.

\section{General distribution}

Algeria (Thaxter 1931), Cameroon (Thaxter 1931), Finland, 'Germany' (Thaxter 1931), Italy (Colla 1925), Malaysia (Sarawak: Thaxter 1931), Poland (Siemaszko \& Siemaszko 1932), St. Helena (Thaxter 1931), Taiwan (Sugiyama 1981), U.S.S.R. (Leningrad Region; Novosibirsk Region).

\section{Host}

Oxytelus piceus (Linnaeus), O. laqueatus (Marsham), O. ferrugineus Kraatz, $O$. alutaceifrons Wollaston and $O$. lucens Bernhauer (Coleoptera, Stahylinidae). The parasite occurs on various parts of the host.

\section{Peyerimhoffiella elengans}

Peyerimhoffiella elegans Maire 1916b:19. - Cryptandromyces brachyglutae Siemaszko \& Siemaszko 1928:205, synonymy according Siemaszko \& Siemaszko 1932. - Corethromyces elegans (Maire) Sie- maszko \& Siemaszko 1932:176 - Figs. 29 a-d, 176 (map).

This species was transferred to Corethromyces by Siemaszko \& Siemaszko, and this treatment was accepted by Scheloske (1969) and Balazuc (1973-74). However, the status of Cryptandromyces brachyglutae is not quite clear. Antheridia was not observed in the Finnish material (because of the fragility of the appendage) and I am not sure about the exact identity of the species. It resembles the illustration in the original description of $P$. elegans and I am provisionally placing it under that name.

The Pselaphidae are very minute beetles (c. $1 \mathrm{~mm}$ ), specimens of which are rather scarce in Finnish museums. The impression that they are rare is contradicted by the fact that at least one species in Finland harbours Laboulbeniales. The beetles occur in moist or wet places in moss and litter.

\section{Material examined}

Finland. Ab: Lohja. - N: Hangö, Tvärminne. Espoo. —Ob: Kempele. On Brachygluta fossulata.

\section{General distribution}

Algeria (Maire 1916a), Federal Republic of Germany (Scheloske 1969), Finland, France (Balazuc 1973-74), Poland (Siemaszko \& Siemaszko 1928).

\section{Host}

Genera of Brachygluta, Batrisodes, Bryaxis, Arcopagus and Tychus (Coleoptera, Pselaphidae). The parasite occurs chiefly on the abdomen of the host.

\section{Peyritschiella protea}

Peyritschiella proteaThaxter 1900:427.

$$
\text { - Figs. } 36 \text { a-c, 106, } 177 \text { (map). }
$$

This species is restricted to Anotylus spp. in Eastern Fennoscandia.

\section{Material examined}

Finland. Ab: Lohja (Anotylus rugosus. A. insecatus). - N: Espoo (A. rugosus). Helsinki (A. rugosus). - Ta: Vanaja ( $A$. rugosus). Pälkäne (A. rugosus, $A$. nitidulus).

U.S.S.R. Leningrad: Poljany (Uusikirkko) (A. rugosus). Karelian A.S.S.R.: Jaakkima (A. rugosus). Petroskoi (A. rugosus).

\section{General distribution}

Algeria (Maire 1920), Belgium (Collart 1945), Finland, Fance (Balazuc 1973-74), German Democratic Republic (Thuringia: Thaxter 1890), Hungary (Banhegyi 1944), Netherlands (Middelhoek 1943a), Poland (Siemaszko \& Siemaszko 1932), United Kingdom (Thaxter 1890), U.S.A. (Thaxter 1908), U.S.S.R. (Leningrad Region; Karelian A.S.S.R.).

\section{Host}

Genera of Acrognathus, Anotylus, Oxytelus, Bledius, Styloxis and Planeustomus (Coleoptera, Staphylinidae). The parasite occurs on various parts of the host.

\section{Rhachomyces furcatus}

Acanthomyces furcatus Thaxter 1893:177. - Rhachomyces furcatus (Thaxter) Thaxter 1895:468. - Figs. 53, 107, 178 (map). 


\section{Material examined}

Finland. Al: Sund (Othius lapidicola). - N: Tuusula ( $O$. punctulatus).

U.S.S.R. Karelian A.S.S.R.: Ahvenjärvi (O. punctulatus).

\section{General distribution}

Algeria (Maire 1916a), Austria (Siemaszko \& Siemaszko 1932), 'Equatorial Africa' (Spegazzini 1915b), Federal Republic of Germany (Scheloske 1969), Finland, France (Balazuc 1973-74), Poland (Siemaszko \& Siemaszko 1932), United Kingdom (Bisby \& Mason 1940), U.S.S.R. (Karelian A.S.S.R.)

\section{Host}

Othius spp. (Coleoptera, Staphylinidae). The parasite occurs on various parts of the host.

\section{Rhachomyces philonthinus}

Rhachomyces philonthinus Thaxter 1900:435. - Figs. 56 a-b, 179 (map).

Material examined

Finland. Al: Finström (Philonthus micans). - Ab: Lohja ( $P$. micans $P$. fulvipes, $P$. albipes, $P$. cruentatus $)$. Sammatti $(P$. micans). Karjalohja (P. albipes). $-\mathrm{N}$ : Tuusula ( $P$. fulvipes). U.S.S.R. Leningrad Region: Uslanka ( $P$. longicornis). - Karelian A.S.S.R.: Kirjavalahti ( $P$. fulvipes, $P$. micans). Sortavala ( $P$. fimetarius).

\section{General distribution}

Algeria (Maire 1920), Belgium (Collart 1945), China (Thaxter 1908), Federal Republic of Germany (Scheloske 1969), Hungary (Banhegyi 1949), Japan (Thaxter 1908), Madagascar (Balazuc 1982), Netherlands (Middelhoek 1943c), Poland (Siemaszko \& Siemaszko 1932), Sweden (Thaxter 1908), St. Helena (Thaxter 1908), United Kingdom (Thaxter 1908), U.S.S.R. (Leningrad Region; Karelian A.S.S.R.).

\section{Host}

Philonthus spp., including related genera, such as Gabrius (Coleoptera, Staphylinidae). The parasite occurs on various parts of the host.

\section{Rickia hyperborea}

Rickia hyperborea Balazuc 1980:216.

$$
\text { - Figs. } 45 \text { a-b, } 180 \text { (map). }
$$

As the host of this species occur along the shores of the Atlantic and Arctic Oceans in Europe and Siberia, $R$. hyperborea cannot be excepted to be found in Finland.

\section{Material examined}

U.S.S.R. Murmansk Region: Kervanto (Micralymma marinum).

\section{General distribution}

France (Balazuc 1980), Norway (Balazuc 1980), U.S.S.R. (Murmansk Region; Magadan Region: Balazuc 1980).

\section{Host}

Micralymma marinum (Ström), M. brevilingue ssp. dicksoni Mäklin (Coleoptera, Staphylinidae). The parasite may be found anywhere on the host.

\section{Rickia peyerimhoffii}

Rickia peyerimhoffii Maire 1916:19. - Figs. 43, 113, 181 (map)
Material examined

Finland. Ab: Lohja (Scaphisoma agaricinum). - Ta: Korpilahti (S. inopinatum).

U.S.S.R. Leningrad Region: Poljany (Uusikirkko). Zelenogorsk (Terijoki). On $S$. agaricinum.

\section{General distribution}

Algeria (Maire 1916c), Federal Republic of Germany (Stadelmann \& Poelt 1962), Finland, Poland (Siemaszko \& Siemaszko 1928), U.S.S.R. (Leningrad Region).

\section{Host}

Scaphisoma agaricinum (Linnaeus), S. inopinatum Löbl, $S$. flavonotatum (Pic) and $S$. assimile Erichson (Coleoptera, Scaphidiidae). The parasite occurs on the pronotum and elytra of the host.

\section{Siemaszkoa fennica Huldén n.sp.}

$$
\text { - Figs. } 11 \text { a-c, } 182 \text { (map). }
$$

Flavidus. Receptaculum ex octo cellulis pedunculum curvatum, 80-100 $\mu \mathrm{m}$ longum conficientibus constat. Appendix $30 \mu \mathrm{m}$ longa. Perithecium rectum vel leviter extrorsum flexum, magnitudine $15 \times 40 \mu \mathrm{m}$. Cellula pedunculi perithecii applanata, 7-8 $\times 5 \mu \mathrm{m}$. Perithecium $a b$ appendice omnino disiunctum. Sporae circiter $18 \mu \mathrm{m}$ longae. Tota longitudo 110-140 $\mu \mathrm{m}$. Matrix: Ptenidium laevigatum Erichson (Coleoptera, Ptiliidae).

Receptacle. Yellowish, nearly hyaline. Eight cells below the perithecium forming a slightly curved stalk, $80-100 \mu \mathrm{m}$ long, $10 \mu \mathrm{m}$ wide, gradually tapering towards foot, second cell smallest, nearly isodiametric, $5 \mu \mathrm{m}$ wide, the other cells elongated.

Appendage. Yellowish. Growing as a continuation of receptacle but smaller and tapering distally, about $30 \mu \mathrm{m}$ long. No branch or antheridia seen.

Perithecium. Yellowish. Upright or slightly outwards bent, about $40 \mu \mathrm{m}$ long and $15 \mu \mathrm{m}$ wide, broadest in middle or just below. Stalk cell slightly flattened, $5 \mu \mathrm{m}$ long and $7-8 \mu \mathrm{m}$ wide. Perithecium slightly inflated basally in outer part. Apex of perithecium slightly oblique, outer margin concave near apex. Row of four cells along inner margin of perithecium and three cells along lateral and outer margins. Perithecium completely free from the appendage. Spores about $18 \mu \mathrm{m}$ long.

Total length from base of foot to tip of perithecium $110-140 \mu \mathrm{m}$

Host. Ptenidium leavigatum Erichson (Coleoptera, Ptiliidae). The parasite was found on the pronotum and elytra of the host.

Holotype. Slide L. Huldén 25, in MZH. Collecting data of the host: Finland. Ab: Uusikaupunki, leg. Söderman.

The genus Siemaszkoa was described by Tavares \& Majewski (1976) on the basis of three species previously referred to Misgomyces, S. ptenidii (Scheloske) Tavares \& Majewski, S. annae (Majewski) Tavares \& Majewski and S. flexa (Majewski) Tavares \& Majewski. A fourth species S. pusillima (Spegazzini) Tavares was transferred from Ecteinomyces by Tavares (1981a). S. fennica differs from S. pusillima and S. annae in its larger size and higher number of receptacle cells and from $S$. ptenidii in its more flattened perithecial stalk cell and different arrangement of the perithecial wall cells ( $S$. ptenidii has four outer wall 
cells in a row, while $S$. fennica has four cells on the inner margin). The new species is presumably closely related to $S$. flexa, having the same arrangement of the perithecial wall cells, flattened perithecial stalk cell and the same shape of the receptacle cells (elongated, the second cell being the smallest in both species). $S$. fennica differs, however, from $S$. flexa in the straight thallus, which is upwards more evenly broadening and slightly different shape of the perithecium.

\section{Material examined}

See the type.

\section{Stigmatomyces axystae Huldén n.sp.}

$$
\text { - Figs. 65, } 183 \text { (map). }
$$

Hyalinus, brunneo-umbratus. Pedunculus duabus cellulis receptaculi confectus $75 \mu \mathrm{m}$ longus. Cellula basalis circiter duplo longior quam subbasalis. Appendix sex paria antheridiorum et singulum antheridium terminale spinosum fert. Appendix $52 \mu \mathrm{m}$ longa. Perithecii venter costis spiralibus praeditus. Perithecium $100 \mu \mathrm{m}$ longum (cellulis basalibus exceptis). Sporae $3 \times 30 \mu \mathrm{m}$. Tota longitudo $200 \mu \mathrm{m}$. Matrix: Axysta cesta (Haliday) (Diptera, Ephydridae).

Receptacle. Hyaline. The two cells forming a stalk about $75 \mu$ in length and $10-15 \mu \mathrm{m}$ width, tapering slightly towards the base. First cell about twice as long as second.

Appendage. Hyaline, with rather distinct brown shade. Basal cell about $15 \mu \mathrm{m}$ long, 5-10 $\mu \mathrm{m}$ wide, tapering distinctly towards base. Stalk cell about 12 $\mu \mathrm{m}$ long, rather uniformly $7 \mu \mathrm{m}$ wide. On main axis six oblique pairs of antheridia and one spiny terminal antheridium. Spine long and distinct. Cells of main axis rather flat. The row of antheridia nearly tangentially directed. Length of appendage from base of stalk cell to tip of terminal antheridium $52 \mu \mathrm{m}$.

Perithecium. Hyaline with distinct brown shade. Spore-bearing part of venter about $35 \times 50 \mu \mathrm{m}$ in size. Distinct, strongly spiralling ridges terminating in four small swelling in the upper part of venter. Width of venter at the swellings about $20 \mu \mathrm{m}$. Neck straight, $50 \mu \mathrm{m}$ in length, tapering gradually upwards from 16 $\mu \mathrm{m}$ to $8 \mu \mathrm{m}$ at constriction below tip. Trace of trichogyne visible just below the constriction. The blunt tip is surrounded by four small processes, slightly diverging from the tip. The apex of each process slightly inflated, resembling a small club. Spores about $3 \times 30$ $\mu \mathrm{m}$.

Total length from base of foot to tip of perithecium $200 \mu \mathrm{m}$.

Host. Axysta cesta (Haliday) (Diptera, Ephydridae). The parasite was found on the dorsal part of the abdomen.

Holotype. Slide L. Huldén 17, in MZH. Collecting data of the host: Finland. N: Vantaa, 21.V.1922, leg. R. Frey.

$S$. axystae is most closely related to $S$. spiralis Thaxter (illustrated by Thaxter 1908 and Dainat \& Dainat 1973). The latter species is much taller and slenderer (about $500 \mu \mathrm{m}$ in length), and has the neck of the perithecium much narrower, with rather dis- tinct and slightly pointed processes at the tip, and the venter of the perithecium with very pronounced ridges. The host of $S$. spiralis belongs to Hyadina (Diptera, Ephydridae).

Material examined

See the type.

\section{Stigmatomyces baeri}

Laboulbenia baeri Knoch 1868:185. - Stigmatomyces muscae Karsten 1869:78. - Stigmatomyces pitraeana Sorokin 1871:39. - Stigmatomyces baeri (Knoch) Peyritsch 1873:250.

$$
\text { - Figs. 66, 112, } 184 \text { (map). }
$$

Boedijn (1923) reported this species on Fannia canicularis (Linnaeus) from the Netherlands. In some experiments made by him with Fannia canicularis and Musca domestica Linnaeus, the parasite infected only the former host. It is very uncertain whether his parasite really represent $S$. beari. It is possible that it was Fanniomyces ceratophorus (Whisler) Majewski, although Boedijn's illustration does not really agree with that species.

\section{Material examined}

Finland. Ta: Kangasala. - Sb: Kuopio. On Musca domestica.

\section{General distribution}

Austria (Peyritsch 1871), Czechoslovakia (Beck 1903), Federal Republic of Germany (Karsten 1869), Finland, Poland (Majewski 1972), Switzerland (Ruffieux 1904), Union of South Africa (Peyritsch 1873), U.S.S.R. (Leningrad Region: Knoch 1868; Charkov Region: Sorokin 1871).

\section{Host}

Musca domestica (Diptera, Muscidae). The parasite may occur anywhere on the host (see Fig. 112). As the host is cosmopolitan, S. baeri is probably much more distributed than is indicated by the records.

Stigmatomyces bottnica Huldén n.sp. - Figs. 63 a-c, 185 (map).

Hyalinus, brunneo-umbratus. Pedunculus cellulis receptaculi confectus 75 um longus. Cellula basalis longior quam subbasalis. Appendix quattuor paria antheridiorum et singulum antheridium terminale spinosum fert. Appendix $50 \mu \mathrm{m}$ longa. Perithecii venter tenuiter constatus. Perithecium 110-120 $\mu \mathrm{m}$ longum (cellulis basalibus exceptis). Collum rectum. Sporae $3 \times 25 \mu \mathrm{m}$. Tota longitudo 200-220 $\mu \mathrm{m}$. Matrix: Ephydra scholtzi Becker (Diptera, Ephydridae).

Receptacle. Hyaline. The two cells forming a stalk, about $75 \mu \mathrm{m}$ in length, tapering uniformly towards the foot, in the upper part about $22 \mu \mathrm{m}$ wide. First cell longer than second.

Appendage. Hyaline, faint brown shade in basal part. Basal cell about $25 \mu \mathrm{m}$ long and $8-10 \mu \mathrm{m}$ wide, distinctly inflated in upper part. Stalk cell $10 \mu \mathrm{m}$ long and uniformly $6 \mu \mathrm{m}$ wide. On the main axis four oblique pairs of antheridia and terminally a single spiny antheridium. The spine small and sometimes 
indistinct. Length of appendage from base of stalk cell to tip of terminal antheridium about $50 \mu \mathrm{m}$. The row of antheridia obliquely inwards directed.

Perithecium. Hyaline with faint brown shade except at base and tip of neck. Spore-bearing part of venter $35-40 \mu \mathrm{m}$ wide and $60-70 \mu \mathrm{m}$ long. Upper part of venter with four very faint and very slightly spiral ridges growing upwards to four small swellings. Width at the swellings about $25 \mu \mathrm{m}$. Neck about 50 $\mu \mathrm{m}$ long, $12 \mu \mathrm{m}$ wide at base and $15 \mu \mathrm{m}$ wide at broadest section below tip. A distinct constriction, about $10 \mu \mathrm{m}$ in width, separating the nearly spherical apical part of neck. Tip with one pair of small inflated processes turning the discharge opening slightly inwards. Spores $3 \times 25 \mu \mathrm{m}$.

Total length from base of foot to tip of perithecium $200-220 \mu \mathrm{m}$.

Host. Ephydra scholtzi Becker (Diptera, Ephydridae). The parasite grew densely on the dorsal side of the abdomen.

Holotype. Slide L. Huldén 16, in MZH. Collecting data of the host: Finland. Om: Lohtaja, 20.VII.1926, leg. Krogerus.

Stigmatomyces bottnica, together with $S$. ephydrae and $S$. setacerae forms a group of species mainly separable on the different cell arrangements at the apex of the perithecium and presumably on the different host species (Figs. 61, 63 and 64). According to Dahl (1959), Ephydra scholtzi and E. riparia are halophilous, while Setacera micans (which previously belonged to Ephydra) prefers freshwater habitats. Differences in ecology of the two Ephydra species are not known, but $E$. scholtzi is much rarer than $E$. riparia. They have been placed in different species groups by Wirth (1975).

Material examined

See the type.

Stigmatomyces chthonicus Huldén n.sp.
\[ \text { - Figs. } 69 \text { a-b, } 186 \text { (map). } \]

Hyalinus, leviter brunneo-umbratus. Pedunculus duabus cellulis receptaculi confectus 70-85 $\mu \mathrm{m}$ longus. Appendix 40-70 $\mu \mathrm{m}$ longa. Perithecii venter in parte superiore quattuor tumoribus distinctis praeditus. Collum perithecii introrsum curvatum. Perithecium 145-150 $\mu \mathrm{m}$ longum (cellulis basalibus exceptis). Sporae $3 \times 18$ $\mu \mathrm{m}$. Tota longitudo 225-260 $\mathrm{mm}$. Matrix: Limosina claviventris Strobl (Diptera, Sphaeroceridae).

Receptacle. Hyaline with faint brown shade. The two cells forming a stalk $70-85 \mu \mathrm{m}$ long and about $15 \mu \mathrm{m}$ wide, the first cell tapering slightly towards base, longer than second.

Appendage. Hyaline with faint brown shade. Basal cell about $20 \mu \mathrm{m}$ long and $10 \mu \mathrm{m}$ wide, somewhat inflated on outer margin, constricted in septum between basal cell and stalk cell. Stalk cell nearly isodiametric about $7 \mu \mathrm{m}$ wide. Main axis consisting of $5-6$ rounded cells equal in size to stalk cell. Each cell, including stalk cell, producing an inwards growing branchlet about $20 \mu \mathrm{m}$ in length constituting an antheridium. Length of appendage from base of stalk cell to tip of last branchlet $40-70 \mu \mathrm{m}$.
Perithecium. Hyaline with faint brown shade. Straight or slightly outwards bent. Spore-bearing part of venter $65-70 \mu \mathrm{m}$ long, $44-48 \mu \mathrm{m}$ wide in middle. Four distinct swellings on upper part of venter at slightly different levels. Neck slightly inwards curved, about $80 \mu \mathrm{m}$ in length, tapering uniformly from 20 $\mu \mathrm{m}$ at base to about $7 \mu \mathrm{m}$ at tip. Apical third of neck indistinctly separated from basal part. Tip with three small processes, the outer one longest and broadest, the two inner ones smaller. Spores $3 \times 18 \mu \mathrm{m}$.

Total length from base of foot to tip of perithecium $225-260 \mu \mathrm{m}$.

Host. Limosina claviventris Strobl (Diptera, Sphaeroceridae). The parasite was found on the abdomen, wings, legs and mesonotum of the host.

Holotype. Slide L. Huldén 22, in MZH. Collecting data of the host: Finland. N: Espoo, Westend, 13. VIII.1959, leg. W. Hackman.

$S$. chthonicus is possibly most closely connected (together with $S$. hackmanii) with $S$. tortimasculus, described by Thaxter (1918) on Leptocera sp. (Diptera, Sphaeroceridae) from Indonesia: Sarawak (illustrated in Thaxter 1931). S. tortimasculus, however, lacks the perithecial swellings in the upper part of the venter, the venter is more strongly inflated and the antheridia grow very irregularly on the appendage. The host of $S$. chthonicus, Limosina claviventris, is common in terrestrial habitats (Hackman 1963) and often found in burrows of voles (Microtus sp.), where it can complete its life cycle.

\section{Material examined}

Finland. N: Espoo, two different localities. On Limosina claviventris.

Stigmatomyces dichaetae Huldén n.sp.

$$
\text { — Figs. 59, } 187 \text { (map). }
$$

Hyalinus, brunneo-umbratus. Pedunculus duabus cellulis receptaculi confectus 100-110 $\mu \mathrm{m}$ longus, cellula basalis et subbasalis aequilongae. Appendix circiter septem antheridia in uno ordine posita fert, in antheridio terminali spina non observata. Appendix $60 \mu \mathrm{m}$ longa. Perithecium robustum, $200 \mu \mathrm{m}$ longum (cellulis basalibus exceptis). Sporae $4 \times 40 \mu \mathrm{m}$. Tota longitudo $320 \mu \mathrm{m}$. Matrix: Dichaeta caudata (Fallén) (Diptera, Ephydridae).

Receptacle. Hyaline with very faint brown shade. The two cells equal in length, forming a stalk $100-$ $110 \mu \mathrm{m}$ long, which tapers gradually from $40 \mu \mathrm{m}$ in the upper part to about $20 \mu \mathrm{m}$ at the base.

Appendage. Hyaline, basal cell and stalk cell with faint brown shade. Basal cell about $50 \mu \mathrm{m}$ long, 10 $\mu \mathrm{m}$ wide at base and broadening upwards to about 15 $\mu \mathrm{m}$. Strongly constricted at septum between basal cell and stalk cell. Stalk cell small, $8 \mu \mathrm{m}$ wide and $10 \mu \mathrm{m}$ long. On the main axis apparently 7 antheridia in one row. Spine not observed on the terminal antheridium. Length of appendage from base of stalk cell to tip of terminal antheridium $60 \mu \mathrm{m}$. The row of antheridia obliquely directed outwards.

Perithecium. Hyaline with brown shade, which is strongest along inner margin and near base. Sporebearing part of venter about $80 \mu \mathrm{m}$ long, $58 \mu \mathrm{m}$ wide 
in upper part. Neck indistinctly separated from venter, slightly outwards curved. The apical third narrower and distinctly separated from the basal twothirds. Tip blunt, about $12 \mu \mathrm{m}$ in width, without processes. Spores $4 \times 40 \mu \mathrm{m}$.

Total length from base of foot to tip of perithecium $320 \mu \mathrm{m}$.

Host. Dichaeta caudata (Fallén) (Diptera, Ephydridae). The parasite was found on the last dorsally visible segment of the abdomen of the host.

Holotype. Slide L. Huldén 18, in MZH. Collecting data of the host: Finland. N: Hangö, Täcktom träsk, leg. W. Hackman.

$S$. dichaetae somewhat resembles $S$. excavatus, described by Thaxter (1918) on Notiphila (Diptera, Ephydridae) from Cameroon (illustrated in Thaxter 1931). S. dichaetae has a more robust perithecium and shorter appendage with more elongated stalk cell. The host, Dichaeta caudata (D. brevicauda Loew), is closely related to Notiphila and is known from freshwater habitats (Dahl 1959). It has two generations in southern Scandinavia.

Material examined

See the type.

\section{Stigmatomyces ephydrae}

Stigmatomyces ephydrae Mercier \& Poisson 1927:226. - Figs. 61, 188 (map).

Material examined

Finland. Om: Jakobstad. On Ephydra riparia.

U.S.S.R. Karelian A.S.S.R.: Keliak. On E. riparia.

\section{General distribution}

Finland, France (Mercier \& Poisson 1927), U.S.S.R. (Karelian A.S.S.R.).

\section{Host}

Ephydra riparia Fallén (Diptera, Ephydridae). The parasite occurs on the abdomen of the host.

Stigmatomyces hackmanii Huldén n.sp.

$$
\text { - Figs. } 71 \text { a-e, 111, } 189 \text { (map). }
$$

Flavidus vel brunneo-umbratus. Pedunculus duabus cellulis receptaculi confectus robustus, 50-60 (-85) $\mu \mathrm{m}$ longus. Pes niger magnus. Appendix ex octo cellulis applanatis constat, quarum quaeque antheridium longum fert. Appendix circiter $40 \mu \mathrm{m}$ longa. Perthecium 105-140 $\mu \mathrm{m}(-180) \mu \mathrm{m}$ longum (cellulis basalibus exceptis). Sporae $3.5 \times 20 \mu \mathrm{m}$. Tota longitudo $200(-400)$ $\mu$ m. Matrix: Limosina schmitzi Duda (Diptera, Sphaeroceridae).

Receptacle. Hyaline, yellowish. The two cells forming a robust stalk $50-60(-85) \mu \mathrm{m}$ long and $25-$ $35 \mu \mathrm{m}$ wide in the upper part, tapering somewhat towards the base. The black foot remarkable large.

Appendage. Hyaline, stalk cell basally with brown shade. Basal cell robust $16(-50) \mu \mathrm{m}$ long and 20 $(-25) \mu \mathrm{m}$ wide, constricted in septum between basal cell and stalk cell. Stalk cell flat, $10-12 \mu \mathrm{m}$ wide and $5 \mu \mathrm{m}$ long. Main axis consisting of eight flat cells basally equal in size to stalk cell, becoming smaller towards apex, the apical one bearing a small spine. Each cell, including stalk cell, producing a short branchlet constituting an antheridium about $10 \mu \mathrm{m}$ in length, growing obliquely inwards; the branchlets arising from the apical cells seems to be irregularly branched. Length of appendage from base of stalk cell to tip of apical branchlet about $40 \mu \mathrm{m}$.

Perithecium. Hyaline. The spore-bearing part of venter $45-60 \mu \mathrm{m}$ long, $40-60 \mu \mathrm{m}$ wide, nearly spherical when mature. Neck of varying length, $60-80$ $(-120) \mu \mathrm{m}$, tapering fairly uniformly towards tip, the apical third very indistinctly separated from the basal part. The tip with two small processes on inner margin and one longer on outer margin. Spores $3-4 \times 20$ $\mu \mathrm{m}$.

Total length from base of foot to tip of perithecium normally about $200 \mu \mathrm{m}$, in extreme morphs from the legs of the host, up to $400 \mu \mathrm{m}$.

Host. Limosina schmitzi Duda (Diptera, Sphaeroceridae). The parasite was most abundantly on the wings, but was sometimes also found on the legs of the host.

Holotype. Slide L. Huldén 23, in MZH. Collecting data of the host: Finland. Ok: Kajaani, leg. W. Hellén.

Stigmatomyces hackmanii is possibly related to $S$. tortimasculus (see comments under $S$. chthonicus), but much more robust, the black foot is unusually large and the cells on the main axis of the appendage are very flat. The robust appearance also suggests a connection with S. papuanus var. leiostoma (Maire 1920), but this has a very long neck on the perithecium. The host of S. hackmanii, Limosina schmitzi, occurs in the burrows of voles (Hackman 1963).

I have named this species in honour of my teacher in entomology, Prof. Walter Hackman.

Material examined

Finland. Ab: Karjalohja. - N: Vantaa. - Om: Nykarleby. - Ok: Kajaani. All records on Limosina schmitzi.

Stigmatomyces hydrelliae

Stigmatomyces hydrelliae Thaxter 1901a:404. - Figs. 57 a-c, 110, 190 (map).

Material examined

Finland. Al: Jomala (Hydrellia griseola). - Ab: Pargas $(H$. incana). Turku, Ruissalo (H. griseola). $-\mathrm{N}$ : Helsinki $(H$. griseola). Vantaa (H. flaviceps). Hangö, Tvärminne ( $H$. incana). - Tb: Laukaa (H. griseola). - Kb: Ilomantsi $(H$. griseola). - Om: Nykarleby (H. flaviceps). - Ks: Kuusamo (H. griseola). - Lk: Muonio (H. griseola).

U.S.S.R. Karelian A.S.S.R.: 'Car.ross. Tengström' = probably Petroskoi (H. griseola).

\section{General distribution}

Finland, France (Dainat 1971), Italy (Rossi \& Cesari Rossi 1979), Poland (Majewski 1972), U.S.A. (Thaxter 1901a), U.S.S.R. (Karelian A.S.S.R.).

Host

Hydrellia flaviceps (Meigen), H. griseola (Fallén) and H. incana Stenhammar (Diptera, Ephydridae). The parasite occurs very constantly dorsally on the abdomen of the host.

Stigmatomyces manicatae Huldén n.sp. - Figs. 62, 191 (map).

Flavidus, hyalinus, brunneo-umbratus. Pedunculus cel- 
lulis duabus receptaculi confectus $140 \mu \mathrm{m}$ longus. Appendix quinque paria antheridiorum et singulum antheridium terminale spinosum fert. Perithecium circiter $280 \mu \mathrm{m}$ longum (cellulis basalibus exceptis). Collum longum, exile, leviter curvatum. Sporae $4 \times 40-45 \mu \mathrm{m}$. Tota longitudo circiter $450 \mu \mathrm{m}$. Matrix: Ochthera manicata (Fabricius) (Diptera, Ephydridae).

Receptacle. Yellowish hyaline. The two cells forming a stalk $140 \mu \mathrm{m}$ in length and $35 \mu \mathrm{m}$ in width, tapering abruptly towards the small black foot. The first cell somewhat smaller than the second.

Appendage. Pale brown, stalk cell darker. Basal cell about $25 \mu \mathrm{m}$ long and $15 \mu \mathrm{m}$ wide, tapering slightly upwards. Stalk cell $15 \mu \mathrm{m}$ long and $10 \mu \mathrm{m}$ wide. Along the main axis arise five obliquely paired antheridia and one spiny terminal antheridium. The row of antheridia directed outwards or slightly obliquely. Length of appendage from base of stalk cell to tip of terminal antheridium about $85 \mu \mathrm{m}$.

Perithecium. Venter hyaline with distinct brown shade, neck and tip pale and hyaline. Spore-bearing part of venter $60 \times 120 \mu \mathrm{m}$, broadest in middle. Neck slightly curved, about $160 \mu \mathrm{m}$ in length, very uniform in width, about $20 \mu \mathrm{m}$ except for the distal $30 \mu \mathrm{m}$, which is slightly tapering. Two pairs of processes on the tip, outer pair about $5 \mu \mathrm{m}$ long, inner pair very short. Spores $4 \times 40-45 \mu \mathrm{m}$.

Total length from base of foot to tip of perithecium about $450 \mu \mathrm{m}$.

Host. Ochthera manicata (Fabricius) (Diptera, Ephydridae). The parasite was found below the tip of the scutellum of the host.

Holotype. Slide L. Huldén 14, in MZH. Collecting data of the host: Finland. Al: Lemland, Flaka, 1224. VIII. 1954, leg. Håkan Lindberg.

This species is obviously very close to $S$. gracilis (Thaxter 1901a, illustrated in Thaxter 1908), but that species has a more distinctly separated neck on the perithecium, pronounced swellings on the neck in the distal third and a much slenderer receptacle. It was said to occur on an Ochthera-like fly (probably $O$. circularis, see Clausen 1977) in Indonesia. Thaxter $(1917,1931)$ also found an American form of S. gracilis on a host called Ochthera mantis (the right species is probably $O$. anatolikos, see Clausen 1977). Thaxter did not describe it as a different taxon, but it is possible that it resembles $S$. manicatae. The exact identity of the host species appears to be important for an understanding of the Stigmatomyces species occurring on Ochthera spp. The host of S. manicatae, O. manicata, is a European species.

Material examined

See the type.

Stigmatomyces mantis Huldén n.sp. - Figs. 60 a-c, 192 (map).

Hyalinus, brunnescenti-umbratus. Pedunculus duabus cellulis receptaculi confectus 50-70 $\mu \mathrm{m}$ longus. Appendix generaliter quinque paria antheridiorum et singulum antheridium terminale spinosum fert. Appendix 60 $\mu \mathrm{m}$ longa. Perithecium 125-160 $\mu \mathrm{m}$ longum (cellulis basalibus exceptis). Apex perithecii vulgo duabus auri- culis longioribus duabusque brevioribus praeditus. Sporae $4 \times 30 \mu \mathrm{m}$. Tota longitudo 190-230 $\mu \mathrm{m}$. Matrix: Ochthera mantis (Degeer) (Diptera, Ephydridae).

Receptacle. Hyaline. The two cells forming a stalk $50-70 \mu \mathrm{m}$ in length. The stalk broadening abruptly at the base, otherwise fairly uniform in width, about $20 \mu \mathrm{m}$. The first cell about twice as long as the second.

Appendage. Hyaline, basal cell and stalk cell with brownish shade. Basal cell about $20 \mu \mathrm{m}$ long and 15 $\mu \mathrm{m}$ wide. Stalk cell isodiametric, about $10 \mu \mathrm{m}$ in width. Main axis usually with five pairs of antheridia and one spiny terminal antheridium. In some cases there may be only four pairs, in one case an additional antheridium was found on the stalk cell. Length of appendage from base of stalk cell to tip of terminal antheridium about $60 \mu \mathrm{m}$. The row of antheridia is rotated to a varying degree and may be inwards or nearly outwards directed.

Perithecium. Hyaline with faint brown shade. Spore-bearing part of venter about $40 \mu \mathrm{m}$ wide and 80 $\mu \mathrm{m}$ long. Neck $45-80 \mu \mathrm{m}$ long, highly variable in shape, always curved or bent inwards to varying degree. Neck divided into basal part, which is longer and broader, usually tapering towards the base, and distal part, which is shorter and tapers slightly towards the tip. When fully developed the tip has one pair of large ear-like processes on outer margin, about $10 \mu \mathrm{m}$ in length, and one pair of small rounded processes on inner margin. The outer pair of processes may be much smaller, and in extreme cases the tip may be quite symmetrical, with four small processes of equal size. Spores $4 \times 30 \mu \mathrm{m}$.

Total length from base of foot to tip of perithecium $190-230 \mu \mathrm{m}$.

Host. Ochthera mantis (Degeer) (Diptera, Ephydridae). The parasite occurs on the dorsal part of the abdomen, mainly on the right side near the base.

Holotype. Slide L. Huldén 15, in MZH. Collecting data of the host: Finland. Ta: Ylörjärvi, 25.VI.1921, leg. R. Frey.

This species is rather variable with respect to the shape of the apex of the perithecium, depending on how well developed it is. The variation is not correlated with the maturity of the perithecium; the different morphs are possibly some kinds of modifications (called 'Wuchsformen' by Scheloske 1969). It is related to $S$. gracilis (see also comments under S. manicatae) but differs in the general shape of the neck of the perithecium and is smaller $(190-230 \mu \mathrm{m}$ vs. about $330 \mu \mathrm{m})$. The host of $S$. mantis, Ochthera mantis, is a holarctic species. It is interesting to note that Ochthe$r a$ is the only genus of Ephydridae with predacious species.

\section{Material studied}

Finland. Ab: Muurla. - Ta: Ylöjärvi. Heinola. — Kb: Ilomantsi. - Ob: Hailuoto. On Ochthera mantis.

\section{Stigmatomyces purpureus}

Stigmatomyes purpureus Thaxter 1901a:404. - Stigmatomyces scatellae Batra 1963:989. - Stigmatomyces purpureus f. scatellae (Batra) Balazuc 1974, in Balazuc 1973-74, vol 43:353.

- Figs. 67 a-b, 193 (map). 
The typical $S$. purpureus was found in Finland on Scatella callosicosta Bezzi (Fig. 67b). The specimens on Scatella stagnalis (Fallén) resemble the shorter form of $S$. purpureus, which was described by Batra as a separate species, $S$. scatellae. Balazuc placed it as a form under $S$. purpureus, but the two forms may represent different species.

Material examined

Finland. Ab: Lohja (Scatella callosicosta). Karjalohja ( $S$. stagnalis). - N: Vantaa (S. callosicosta).

\section{General distribution}

Finland, France (Dainat \& Dainat 1973), India (Batra 1963 as S. scatellae), Italy (Rossi \& Cesari Rossi 1979), Poland (Majewski 1981), United Kingdom (Biffen 1909), U.S.A. (Thaxter 1901a)

Host

Scatella stagnalis, $S$. callosicosta and $S$. paludum (Meigen) (Diptera, Ephydridae). The parasite occurs on the abdomen of the host.

Stigmatomyces scaptomyzae

Stigmatomyces scaptomyzae Thaxter 1901a:400.

$$
\text { - Figs. } 70 \text { a-b, } 194 \text { (map). }
$$

Material examined

Finland. N: Hangö, Tvärminne. Sibbo. - St: Pori, Reposaari. On Scaptomyza pallida.

General distribution

Finland, France (Dainat \& Dainat 1973), Italy (Rossi \& Cesari Rossi 1979), Poland (Majewski 1972), U.S.A. (Thaxter 1908), Venezuela (Thaxter 1908).

Host

Scaptomyza pallida (Zetterstedt) and S. graminum (Fallén) (Diptera, Drosophilidae). The parasite occurs on the abdomen of the host.

Stigmatomyces setacerae Huldén n.sp.

$$
\text { - Figs. } 64 \text { a-c, } 195 \text { (map). }
$$

Hyalinus, brunneo-umbratus. Pedunculus cellulis duabus receptaculi confectus 80-90 $\mu \mathrm{m}$ longus. Appendix quattuor antheridia in uno ordine posita et singulum antheridium terminale spinosum fert. Perithecii venter quattuor costis praeditus, in parte superiore in tumores quattuor humiles terminans. Perithecium 110-125 $\mu \mathrm{m}$ longum (cellulis basalibus exceptis). Collum leviter curvatum. Apex duobus paribus processuum in uno latere sitis praeditus. Sporae $3 \times 20 \mu \mathrm{m}$. Tota longitudo 200 $220 \mu \mathrm{m}$. Matrix: Setacera micans (Haliday) (Diptera, Ephydridae).

Receptacle. Hyaline. The two cells forming a stalk $80-90 \mu \mathrm{m}$ long and $12-25 \mu \mathrm{m}$ wide, gradually broadening upwards. First cell slightly longer than second.

Appendage. Hyaline with faint brown shade. Basal cell about $20 \mu \mathrm{m}$ long and $10 \mu \mathrm{m}$ wide, slightly inflated above. Constricted at the septum between basal cell and stalk cell. Stalk cell $12-15 \mu \mathrm{m}$ long and $6-7$ $\mu \mathrm{m}$ wide. Main axis with four antheridia in one row and one spiny terminal antheridium. Spine long and distinct. The appendage curved inwards. Length of appendage from base of stalk cell to tip of terminal antheridium about $60 \mu \mathrm{m}$.

Perithecium. Hyaline with brown shade, paler on basal part of neck. Spore-bearing part of venter $65-$ $75 \mu \mathrm{m}$ long and $25-40 \mu \mathrm{m}$ wide, broadest just above middle. Four low symmetrially located ridges in upper third of venter terminating above in four low swellings just below neck. Width at swellings $20-25$ $\mu \mathrm{m}$. Neck curved inwards, $45-50 \mu \mathrm{m}$ long from base to tip of processes, $15-18 \mu \mathrm{m}$ wide, slightly constricted in apical third. Tip as in Figs. $64 \mathrm{~b}-\mathrm{c}$. The prosesses of tip about $8 \mu \mathrm{m}$ in length. Spores $3 \times 20 \mu \mathrm{m}$.

Total length from base of foot to tip of perithecium $200-220 \mu \mathrm{m}$.

Host. Setacera micans (Haliday) (Diptera, Ephydridae). The parasite occurs on the left anterior cormer of the first abdominal segment.

Holotype. Slide L. Huldén 19, in MZH. Collecting data of the host: Finland. Ob: Hailuoto, leg. R. Frey.

Closely related to $S$. ephydrae and $S$. bottnica, but differs in the shape of the apex of the perithecium (Figs. 61, 63 and 64). The neck of the perithecium is also slightly shorter than in the two other species.

The host of S. setacerae, Setacera micans, occurs in the vicinity of freshwater habitats, while those of the others are halophilous (Dahl 1959).

Material examined

See the type.

Stigmatomyces subterraneus Huldén n.sp.

$$
\text { - Figs. 68, } 196 \text { (map). }
$$

Hyalinus, tenuiter brunnescenti-umbratus. Pedunculus cellulis receptaculi confectus exilis, 80-130 $\mu \mathrm{m}$ longus. Appendix ex 6-7 cellulis turgidis constat, quarum quaeque singulum antheridium fert. Appendix circa $65 \mu \mathrm{m}$ longa. Perithecium exile, extrorsum curvatum, tumoribus quattuor distinctis praeditum, 105-140 $\mu \mathrm{m}$ longum (cellulis basalibus exceptis). Collum rectum. Sporae 2$3 \times 18 \mu \mathrm{m}$. Tota longitudo 260-320 $\mathrm{mm}$. Matrix: Limosina talparum Richards (Diptera, Sphaeroceridae).

Receptacle. Hyaline. The two cells forming a stalk of varying length, $80-130 \mu \mathrm{m}$, and uniform width, $15-20 \mu \mathrm{m}$. First cell a half to two-thirds as long as the second.

Appendage. Hyaline, only stalk cell with faint brown shade. Basal cell elongate, up to $35 \mu \mathrm{m}$ long and $10 \mu \mathrm{m}$ wide in the middle, tapering slightly towards the ends. Stalk cell small and flat, $10 \mu \mathrm{m}$ wide and $5 \mu \mathrm{m}$ long. The main axis above the stalk cell consisting of about $6-7$ cells inflated at outer margin, nearly equal in size to the stalk cell, inner margin of each cell, including stalk cell, with an antheridium about $25 \mu \mathrm{m}$ in lenght, the upper ones being shorter. The last two or three axis cells possibly irregularly branched and apparently terminating in antheridia. Lenght of appendage from base of stalk cell to tip of last branchlet about $65 \mu \mathrm{m}$.

Perithecium. Hyaline with very faint brown shade, bent outwards, rarely straight. Spore-bearing part of venter $45-70 \mu \mathrm{m}$ long and $30-42 \mu \mathrm{m}$ wide, with four very pronounced swellings in the upper region, at somewhat different levels. Neck fairly straight, 
$60-70 \mu \mathrm{m}$ long, about $20 \mu \mathrm{m}$ wide at base, tapering uniformly for three quarters of its length, the apical quarter tapering slightly more strongly. Tip rather narrow, about $5 \mu \mathrm{m}$ in width. Tip with one very small swelling on inner side $2-3$ in width. Spores $2-3 \times$ $18 \mu \mathrm{m}$

Total length from base of foot to tip of perithecium $260-320 \mu \mathrm{m}$.

Host. Limosina talparum Richards (Diptera, Sphaeroceridae). The parasite occurs mainly on the abdomen, but sometimes also on the legs of the host.

Holotype. Slide L. Huldén 21, in MZH. Collecting data of the host: Finland. N: Espoo, Westend, 27.VI.1959, leg. W. Hackman.

Stigmatomyces subterraneus is very closely related to $S$. divergatus, described by Thaxter (1931) from Sumatra on Leptocera sp. (Diptera, Sphaeroceridae). The latter differs in its smaller size $(160-200 \mu \mathrm{m}$ against $260-320 \mu \mathrm{m}$ ) and slightly zigzag-shaped thallus, which is not as slender as in S. subterraneus. It is possible that $S$. subterraneus will prove to be merely a subspecies of $S$. divergatus, but more records are required from intervening areas.

The host of S. subterraneus, Limosina talparum, occurs very typically in burrows of Microtus (voles) and Talpa (moles) but unlike its relative Limosina claviventris, it has a much narrower ecological amplitude, being restricted to inhabited burrows (Hackman 1963).

Material examined

See the type.

Symplectromyces lapponicus Huldén n.sp.

$$
\text { - Figs. } 49 \text { a-d, } 197 \text { (map). }
$$

Pedunculus tribus cellulis basalibus receptaculi confectus $60 \mu \mathrm{m}$ longus, sursum gradatim infuscatus. Cellula IV fusca, fere opaca. Appendices fuscae, ramulis superne hyalinis. In ramulis cellulae rostratae. Rami antheridiferi breves, antheridia 3-4 ferentes. Perithecia bina, fusca, $100 \mu \mathrm{m}$ longa. Sporae $25 \mu \mathrm{m}$ longae. Tota longitudo $225 \mu \mathrm{m}$. Matrix: Quedius boops (Gravenhorst) (Coleoptera, Staphylinidae).

Receptacle. The three first cell forming a stalk about $60 \mu \mathrm{m}$ in length. First cell yellow brown, the three following following cells gradually darkening, the fourth cell dark brown and nearly opaque. First cell rather narrow, slightly longer than broad, second cell very flattened and about three times as broad as long, third cell about twice as broad as long.

Appendage. Dark brown, the branchlets hyaline towards the tips. A ring of secondary branches arises from the fourth cell above the foot. Beak-like apical cells are present on the outwards directed branchlets in young specimens, but are soon broken; these cells $3-5$ times as long as their base. Antheridial branches hidden among sterile branches, short, 25-30 $\mu \mathrm{m}$ in length, only three or four antheridia in row.

Perithecium. Dark brown, paler towards base and tip. Narrowly ova, $45 \times 100 \mu \mathrm{m}$ in size. Four small sphaerical processes below the tip. Stalk of perithecium short, hidden among branches of appendage.
Spores about $25 \mu \mathrm{m}$ in length.

Total length from base of foot to tip of perithecium $225 \mu \mathrm{m}$.

Host. Quedius boops (Gravenhorst) (Coleoptera, Staphylinidae). The parasite was found on the legs and abdomen of the host.

Holotype. Slide L. Huldén 12, in MZH. Collecting data of the host: Finland. Lk: Kittilä, leg. O. Renkonen.

S. lapponicus differs from $S$. vulgaris in the smaller size, smaller spores, beak-like sterile branchlets and very short antheridial branches with only 3-4 antheridia (in $S$. vulgaris $7-10$ antheridia in row).

Material examined

See the type.

\section{Symplectromyces rarus Huldén n.sp.} — Figs. 51 a-b, 198 (map).

Receptaculum fuscum, ad basin pallidius. Pedunculus tribus cellulis basalibus confectus $60 \mu \mathrm{m}$ longus. Rami appendiculati subbrunnei, ad basin fuscelli, $100 \mu \mathrm{m}$ longi. Rami antheridiferi longi, antheridia numerosa ferentes. Perithecia regulariter bina, fusiformia, fusca, cellula pedunculi pallida. Perithecium 180-200 $\mu \mathrm{m}$ longum. Sporae $4 \times 35 \mu \mathrm{m}$. Tota longitudo circiter 370 $\mu \mathrm{m}$. Matrix: Quedius fuliginosus (Gravenhorst) (Coleoptera, Staphylinidae).

Receptacle. Dark brown, paler near the base. The stalk consisting of three superposed cells, broadening uniformly from about $15 \mu \mathrm{m}$ to $35 \mu \mathrm{m}$, about $60 \mu \mathrm{m}$ in length. The first cell slightly longer than broad, the second and third cells slightly broader than long.

Appendage. Branches pale brown, basally dark brown. The ring of branches arising from the fourth cell above the foot. The outer branches have short blunt branchlets directed outwards, the inner branches (= overlying branches) bear 5-7 simple antheridia along the inner margin. Branches up to $100 \mu \mathrm{m}$ in length.

Perithecium. Dark brown, basally and apically slightly paler, stalk cell very pale, nearly hyaline. Stalk cell about $60 \mu \mathrm{m}$ long and $20 \mu \mathrm{m}$ wide, very distinctly separable from perithecium. Perithecium very regularly spool-shaped, $180-200 \mu \mathrm{m}$ long and $50-55 \mu \mathrm{m}$ wide. Apex relatively bluntly rounded. Spores about $4 \times 35 \mu \mathrm{m}$. The perithecia occur very regularly in pairs of equal size.

Total length from base of foot to tip of perithecium about $370 \mu \mathrm{m}$.

Host. Quedius fuliginosus (Gravenhorst) (Coleoptera, Staphylinidae). The parasite occurs only on the dorsal side of the last abdominal segment of the host.

Holotype. Slide L. Huldén 13, in MZH. Collecting data of the host: Finland. N: Vantaa, 28.X.1934, leg. P. H. Lindberg.

Symplectromyces rarus is closely related to $S$. vulgaris. It differs from the latter in its more elegant and symmetrical appearance, more distinctly separated stalk of perithecium, dark brown perithecium, contrasting with the very pale stalk, and smaller spores. It occurs exclusively on the dorsal side of the last abdominal segment of Quedius fuliginosus. 
Material examined.

Finland. N: Espoo. Vantaa. Helsinki. Kirkkonummi. - St:

Yläne. All records on Quedius fuliginosus.

\section{Symplectromyces vulgaris}

Teratomyces vulgaris Thaxter 1900:431. - Symplectromyces vulgaris (Thaxter) Thaxter 1908:315.

$$
\text { - Figs. } 50 \text { a-b, } 199 \text { (map). }
$$

Symplectromyces vulgaris was earlier the only species in the genus. The main characters differentiating it from the newly described $S$. lapponicus and $S$. rarus are the large, somewhat clumsy appearance and large spores (about $60 \mu \mathrm{m}$ in length). It is often less pigmented than the other species. The main host in Eastern Fennoscandia is Quedius mesomelinus (Marsham).

Thaxter (1908) reports occurrence on Philonthus sp. (Coleoptera, Staphylinidae), but this is either a wrongly determined or an accidental host (cf. Benjamin 1968).

The here illustrated specimen (Fig. 50a) is exceptional in having an additional horizontal septum in the perithecial stalk cell.

\section{Material examined}

Finland. Al: Saltvik (Quedius mesomelinus). Geta (Q. mesomelinus). Sund ( $Q$. cinctus). - Ab: Turku, Ruissalo ( $Q$. cinctus). Lohja (Q. mesomelinus, Q. limbatus). - N: Helsinki (Q. cinctus). Vantaa ( $Q$. mesomelinus). - Ta: Lammi ( $Q$. limbatus). - Sb: Viitasaari (Q. mesomelinus ). - Kb: Juuka (Q. mesomelinus).

U.S.S.R. Leningrad Region: Mičurinskoe (Valkjärvi) ( $Q$. mesomelinus). Murmansk Region: Pečenga (Petsamo) ( $Q$ fulvicollis). Varsuga (Q. mesomelinus).

General distribution

Belgium (Collart 1945), 'Bengal' (Thaxter 1900), Canada (Thaxter 1900), Federal Republic of Germany (Scheloske 1969), Finland, Hungary (Thaxter 1900), Italy (Rossi \& Cesaro Rossi 1978), Netherlands (Middelhoek 1943b), Portugal (Thaxter 1908), Spain (Thaxter 1908), United Kingdom (Thaxter 1900), U.S.A. (Benjamin 1968), U.S.S.R. (Leningrad Region; Murmansk Region), Yugoslavia (Siemaszko \& Siemaszko 1932).

\section{Host}

Quedius spp. (Coleoptera, Staphylinidae). The parasite occurs on various parts of the host.

\section{Teratomyces brevicaulis}

Teratomyces brevicaulis Thaxter 1894:99. - Figs. 52 a-d, 200 (map).

First records from Europe.

In the southwestern part of Finland this species occurs together with Diplomyces clavifer (see comments under that species).

\section{Material examined}

Finland. Al: Eckerö. Geta. - Ab: Lohja. - Sa: Ristiina. On Erichsonius cinerascens.

U.S.S.R. Karelian A.S.S.R.: Saravaara. On E. cinerascens.
General distribution

Finland, U.S.A. (Thaxter 1894), U.S.S.R. (Karelian A.S.S.R.).

Host

Erichsonius (Actobius) nanus (Horn) and E. cinerascens (Gravenhorst) (Coleoptera, Staphylinidae). The parasite occurs chiefly on the abdomen of the host.

\section{Teratomyces philonthi}

Teratomyces philonthi Thaxter 1900:432.

$$
\text { - Figs. 54, } 201 \text { (map). }
$$

The host genus of this parasite, Gabrius, was long treated as a sugenus of Philonthus, but is now generally considered a separate genus. Teratomyces philonthi does not occur on Philonthus.

Material examined

Finland. Ab: Lohja (Gabrius trossulus).

\section{General distribution}

Federal Republic of Germany (Scheloske 1969), Finland, France (Balazuc 1973-74), Hungary (Thaxter 1900), Italy (Rossi \& Cesari Rossi 1978), Netherlands (Middelhoek 1943a).

Host

Gabrius trossulus (Nordmann) and G. pennatus Sharp (Coleoptera, Staphylinidae). The parasite occurs distally on the abdomen of the host.

\subsection{Notes on non-laboulbeniaceous parasites in Finland}

\subsubsection{Amphoromorpha sp.}

A few specimens of an ectoparasitic fungus, apparently belonging to the genus Amphoromorpha (Deuteromycetes: Gloeohaustoriales), were found on the abdomen of a specimen of Atheta longicornis (Gravenhorst) (Coleoptera, Staphylinidae) from Ob: Rovaniemi, Pisavaara. In Figs. 99 a-d (map in Fig. 203) four specimens of the fungus are illustrated. They are very hyaline and the size varies from $60-75 \mu \mathrm{m}$ in length and $10-15 \mu \mathrm{m}$ in width. No distinct structures were seen except for one or two spine-like processes at the apex of the (?)unicellular thallus. The structure of the foot is also indistinct. They resemble $\mathrm{A}$. mirabilis diescribed on a staphylinid beetle from Poland by J. \& W. Siemaszko (1928), but differ in the smaller size. For the present I think it is best not to describe this fungus as a new species.

\subsubsection{A hyperparasite on Laboulbenia argutoris}

A hyperparasitic fungus of unknown systematic position was found on Laboulbenia argutoris from two localities in South Finland (Figs. $100 \mathrm{a}-\mathrm{b}$, map in Figs. 202). In both cases the host of $L$. argutoris was Pterostichus diligens (Coleoptera, Carabidae). The larger specimen (Fig. 100a) grew on the outer appendage and the smaller (Fig. 100b) on the perithecium of the parasite. The thallus consists of $4-10$ cells, 
with a black foot as in Laboulbeniales. No other distinct structures were seen. The beetles were collected in Al: Finström and Ab: Lohja.

Acknowledgements. I wish express my sincere thanks to Dr. Isabelle Tavares (U.S.A., California) for helping me to evaluate and solve many kinds of problems which have arisen during the course of this study.

Prof. Teuvo Ahti, Prof. Martin Meinander and Prof. Yrjö Vasari gave valuable criticism of the manuscript. Prof. Walter Hackman, Dr. Antti Jansson, Dr. Olof Biström, Dr. Eero Helve and Dr. Hans Silfverberg gave me assistance in determinations of selected insects, supplying literature and discussions of the ecology and life-cycles of the insects.

I also wish to thank the following persons for loaning or collecting important material for the study: Prof. Esko Kangas, Mr. Anders Albrecht, Mr. Tom Clayhills, Mr. Pekka Hiilivirta, Miss Andrea Packalén, Dr. Esa Ranta, Mr. Hannu Räisänen, Mr. Juha Siitonen and Mr. Jari Tuiskunen.

I am grateful to Mrs. Anna Damström for revising the English text, and to Mrs. Marja Kaila for revising the Latin descriptions.

My studies were supported by Societas pro Fauna et Flora Fennica and Oscar Öflund Foundation. 
11 a

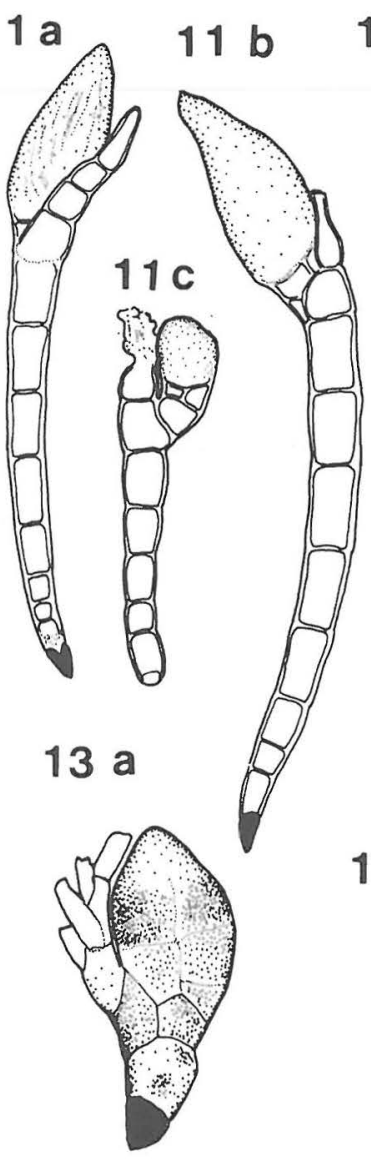

13 a

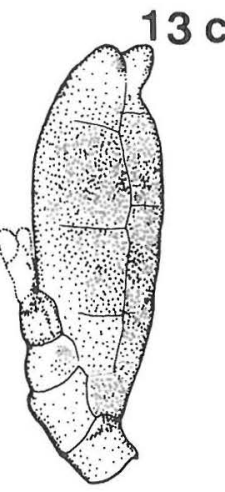

$11 \mathrm{~d}$

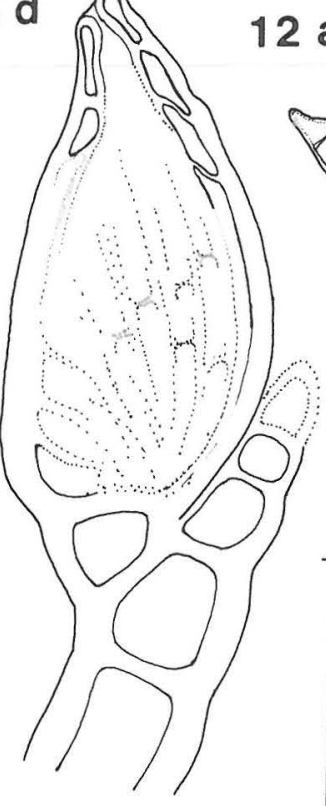

$13 \mathrm{~b}$

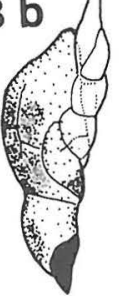

$40 \mu \mathrm{m}$

$11 d$

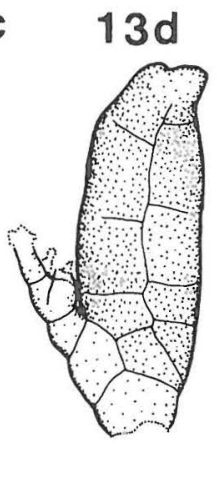

$13 \mathrm{e}$

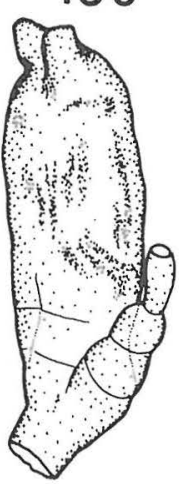

$12 b$

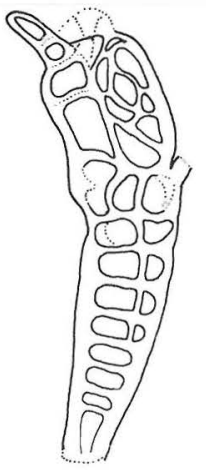

$14 a$

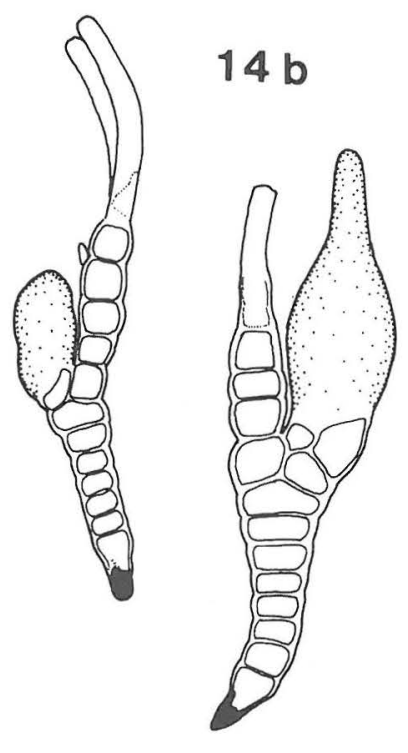

$12 \mathrm{C}$

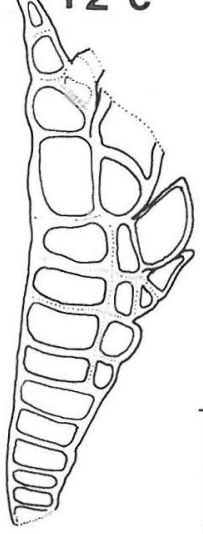

$100 \mu \mathrm{m}$

11 a - c,

$14 \mathrm{C}$

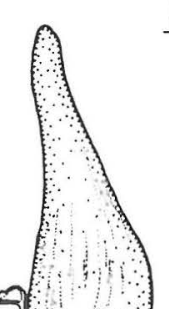

8.

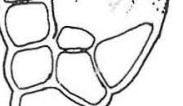

Figs. 11-14. - 11: Siemaszkoa fennica n.sp. from Ptenidium laevigatum, a)-b) mature specimens, c) young specimen, d) perithecium in detail. b) holotype. - 12: Ecteinomyces agathidii from Cyrtusa subtestacea, a) mature, b) immature and c) mature (perithecium broken) specimens. - 13: Corethromyces niger from Ptomaphagus subvillosus, a)-e) variation of thallus, a)-b) possibly immature. - 14: Ecteinomyces trichopterophilus from Acrotrichis sp., a) immature, b) nearly mature and c) mature specimen. 


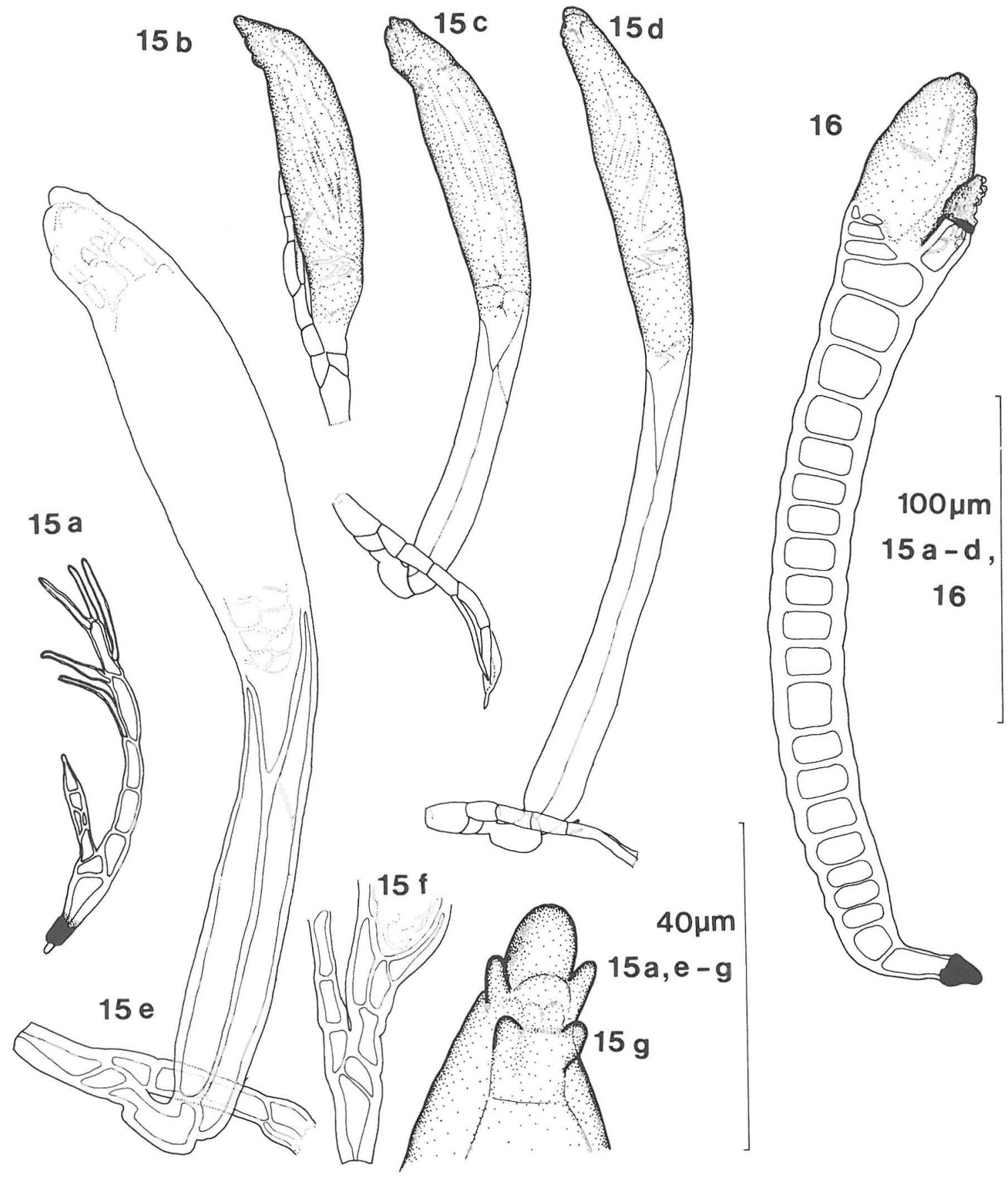

Fig. 15-16. - 15: Autophagomyces falcatus from Cryptophagus pilosus, a) young thallus with intact appendage, b) typical specimen, c)-d) long morphs, e)-f) cell arrangements of long and typical morphs in detail, g) apex of perithecium. - 16: Misgomyces dyschirii from Dyschirius globosus, compound antheridium visible in cell III. 


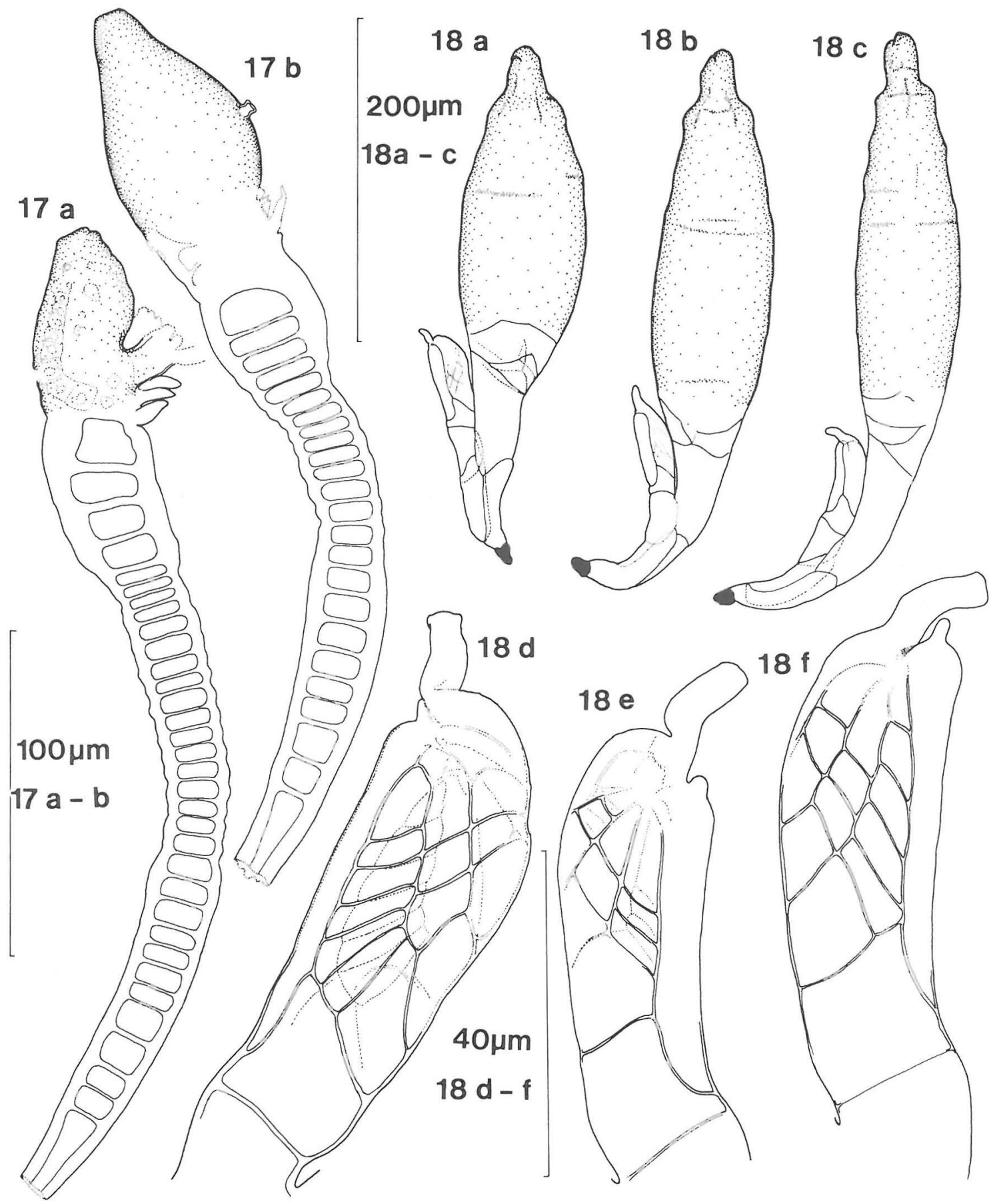

Figs. 17-18. - 17: Helodiomyces elegans from Dryops auriculatus, a)-b) two overmature specimens. - 18: Eucantharomyces fennoscandicus n.sp. from Agonum quadripunctatum, a)-c) variation of mature thallus, d)-f) compound antheridia in detail. c) holotype. 


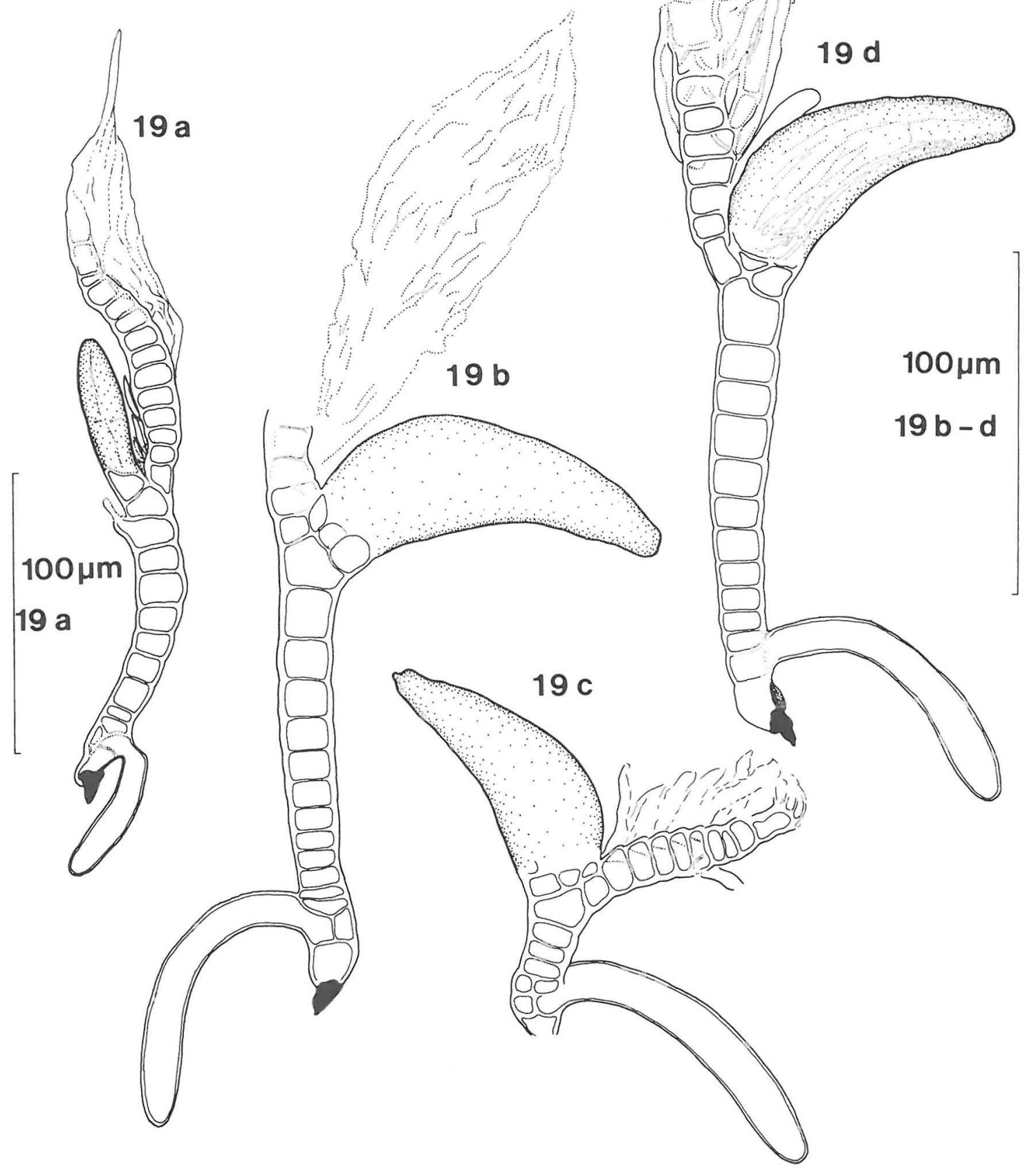

Fig. 19. Hydrophilomyces arcuatus n.sp. from Ochthebius minimus, a) immature specimen, b)-d) mature specimens. d) holotype. 


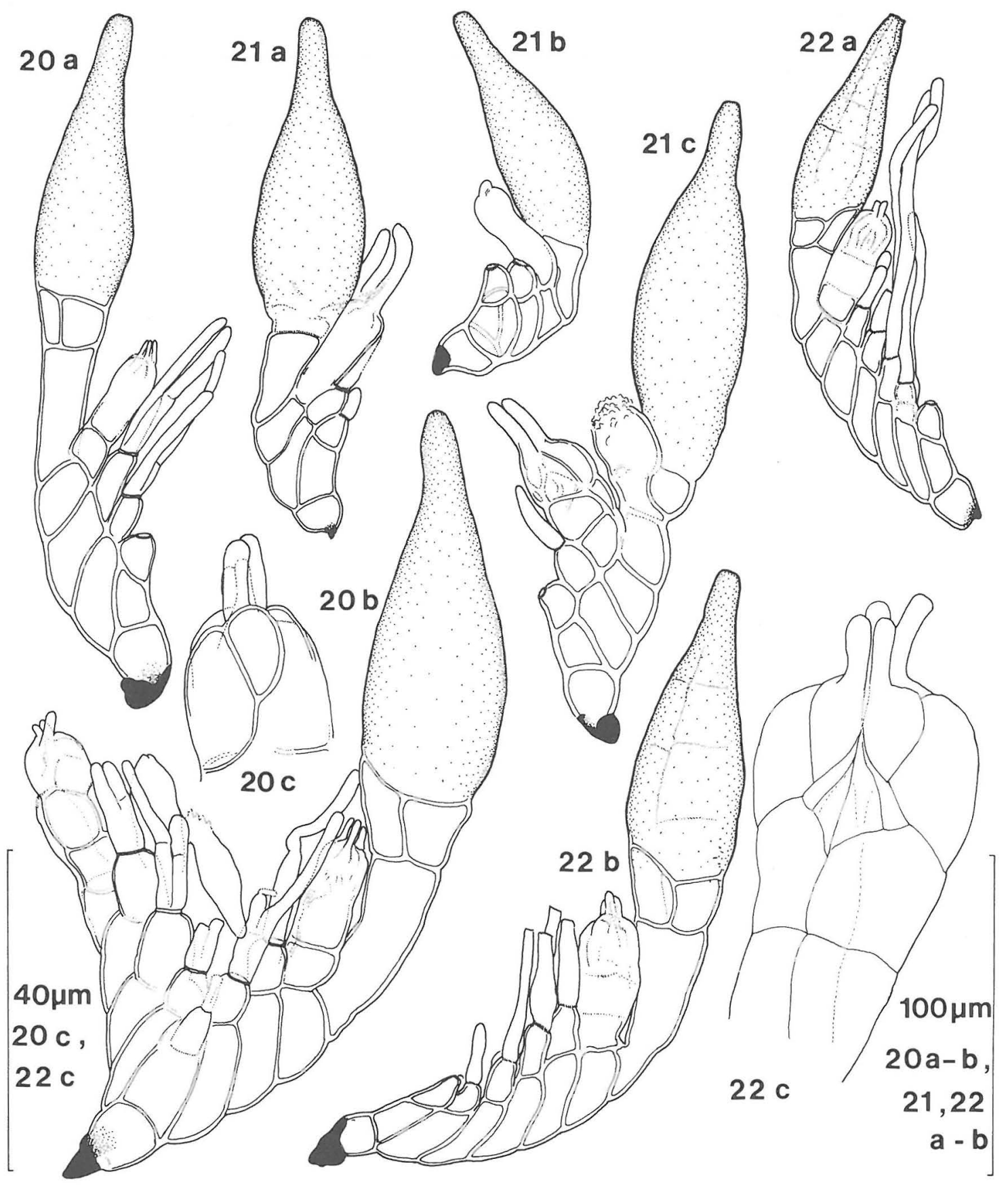

Figs. 20-22. - 20: Monoicomyces furcatus from Oxytelus laqueatus, a) simple morph, b) typical furcate morph, c) compound antheridium. - 21: Monoicomyces invisibilis from Platystethus arenarius, a)-c) variation of thallus. - 22: Monoicomyces oxytelis n.sp. from Oxytelus fulvipes, a)-b) mature specimens, c) compound antheridium, b) holotype. 


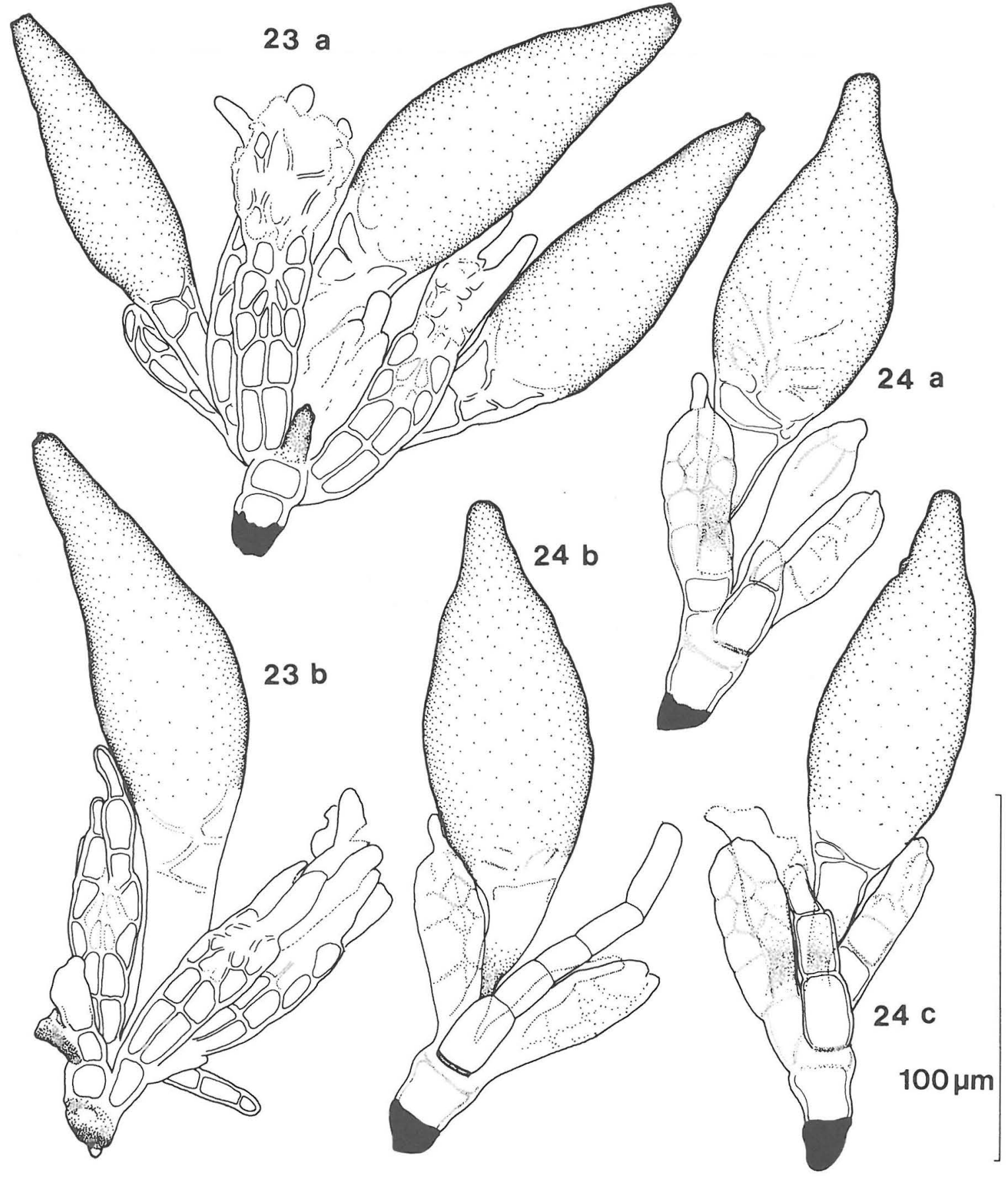

Figs. 23-24. - 23: Monoicomyces britannicus from Atheta longicornis, a)-b) variation of thallus. - 24: Monoicomyces homalotae from Atheta paracrassicornis, a)-c) variation of thallus. 


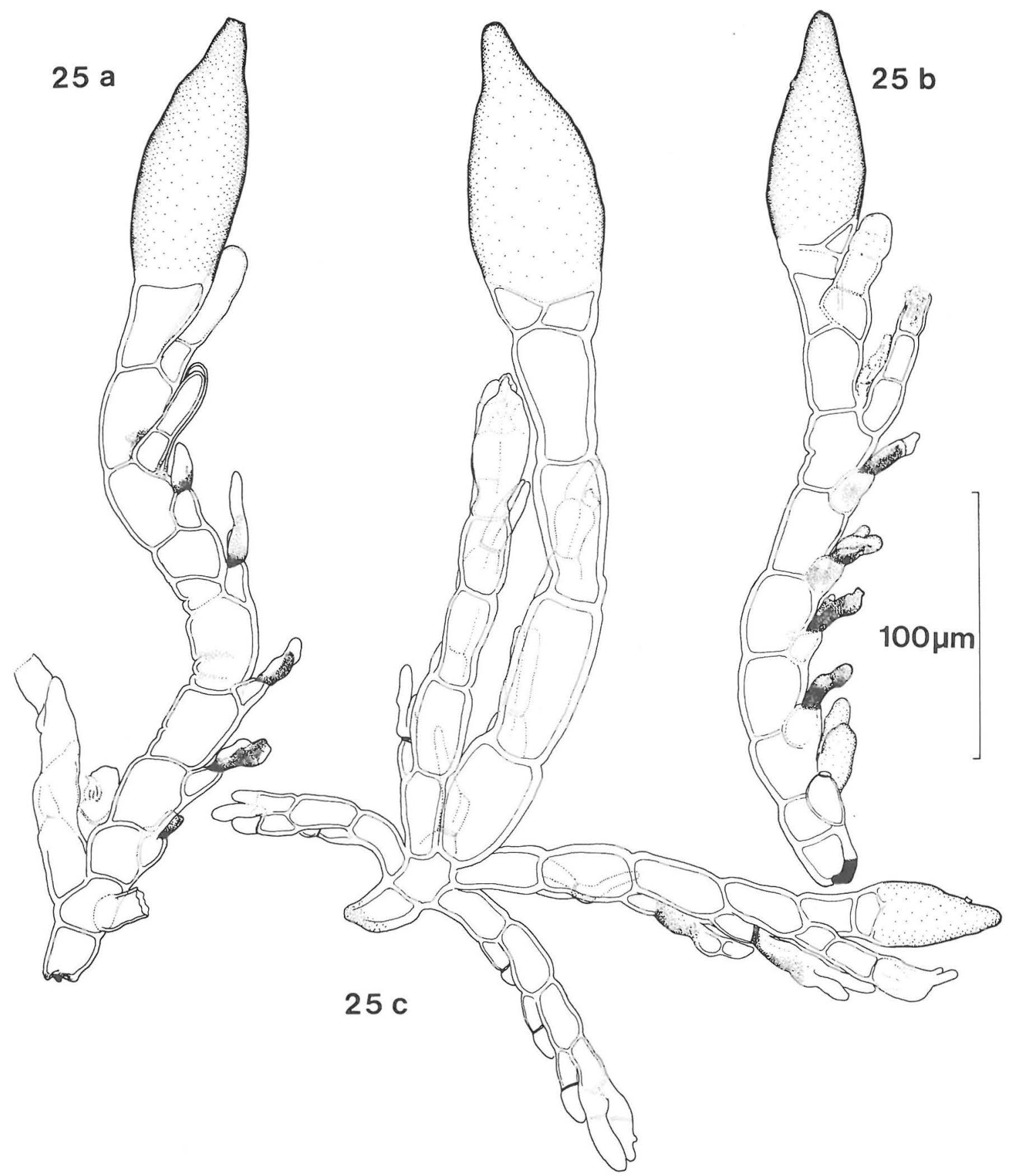

Fig. 25. Monoicomyces sanctae-helenae from Oxytelus piceus, a)-b) 'roccae'-like morphs, c) typical morph. 

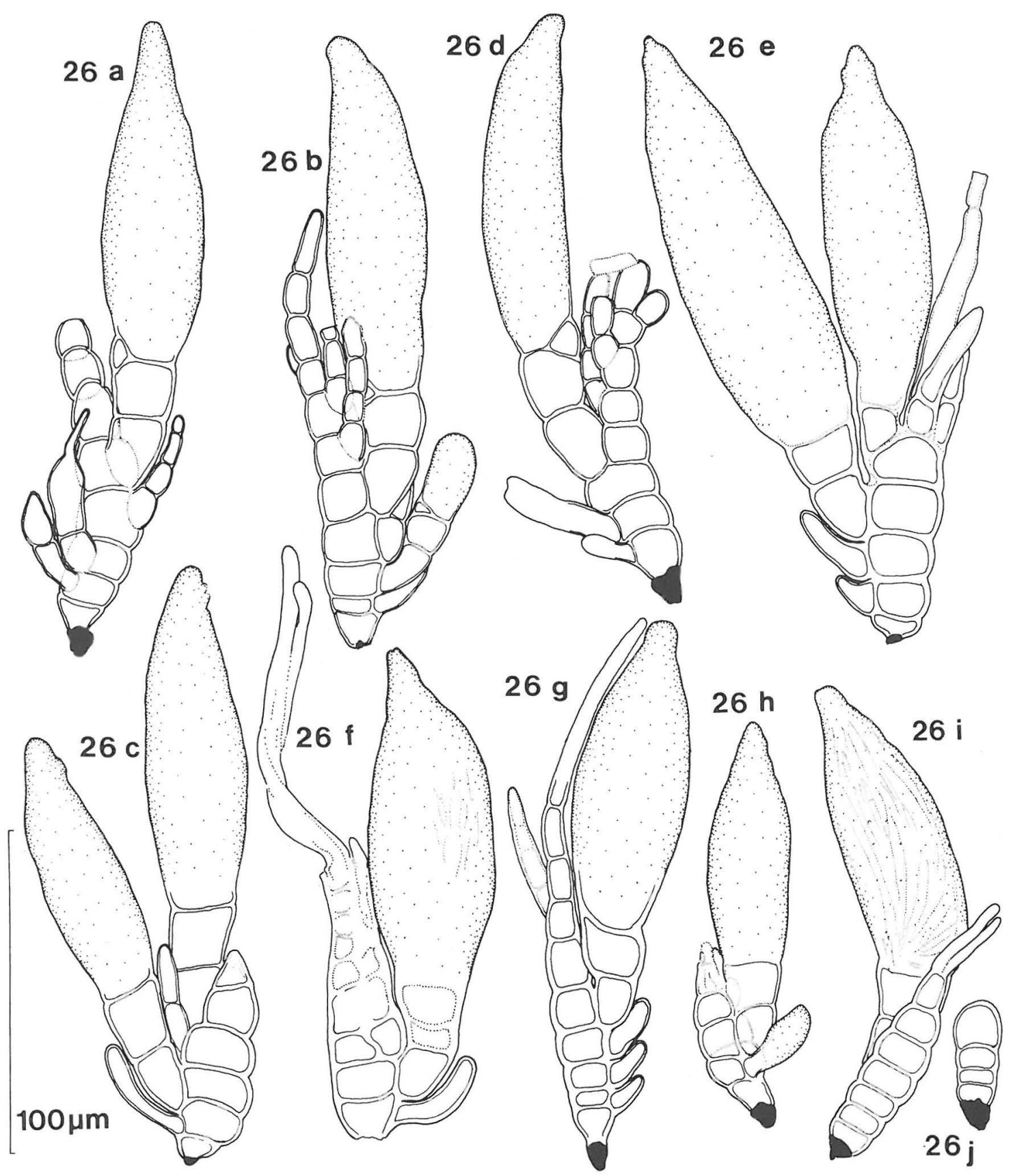

Fig. 26. Asaphomyces tubanticus from a)-c) Catops fuscus, d) C. nigricans, e) C. alpinus, f) C. fuliginosus, g) C. nigrita, h)-j) Sciodrepoides watsoni. j) young specimen in four cell stage. 


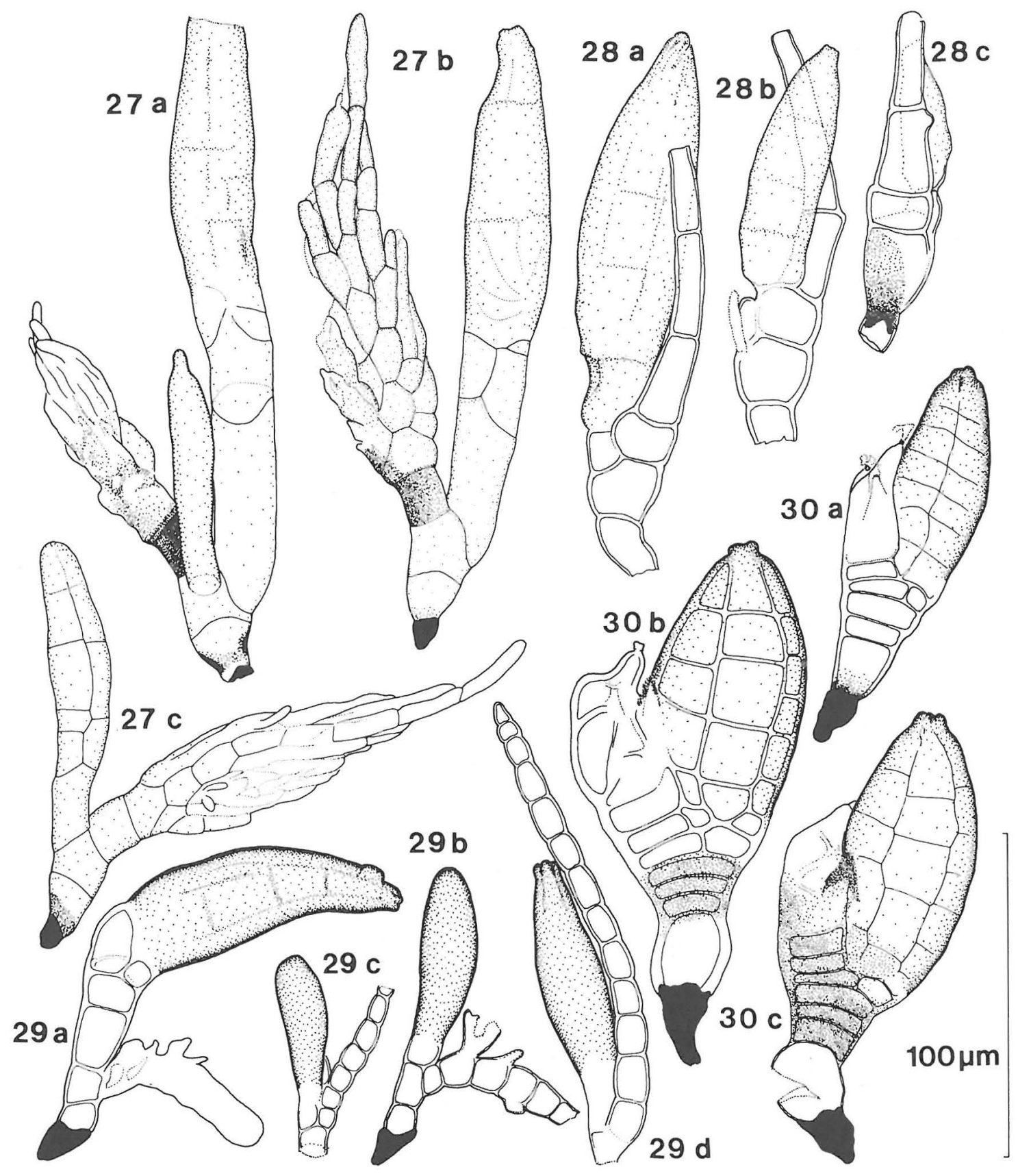

Figs. 27-30. - 27: Corethromyces henrotii from Choleva septentrionis, a)-b) mature specimens, c) immature specimen. - 28: Cantharomyces italicus from Dryops griseus, a) mature specimen, b)-c) immature specimens. - 29: Peyerimhoffiella elegans from Brachygluta fossulata, a) mature specimen, b)-d) immature specimens in different stages. - 30: Hydraeomyces italicus, a) typical morph from Haliplus fulvicollis, b)-c) 'italicus'-like morph from Haliplus fulvus lapponum. 

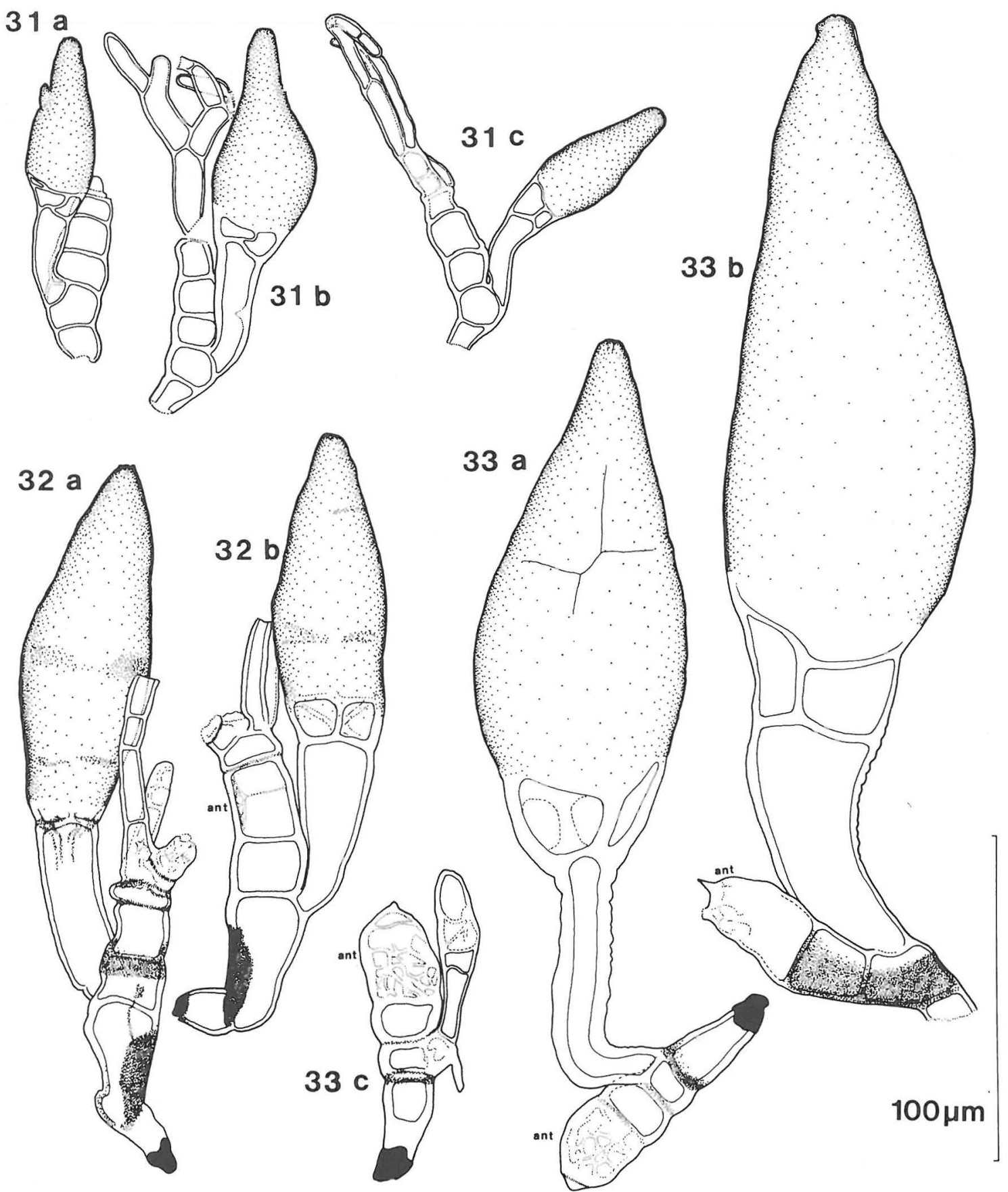

Figs. 31-33. - 31: Cantharomyces orientalis from a)-b) Carpelimus elongatulus, c) Carpelimus corticarius. - 32: Cantharomyces aploderi $\mathrm{n} . \mathrm{sp}$. from Aploderus caesus, a)-b) variation of thallus, b) holotype. - 33: Haplomyces texanus from a) and c) Bledius filipes, b) Bledius diota. c) young specimen. - Abbreviation: ant. = compound antheridium. 


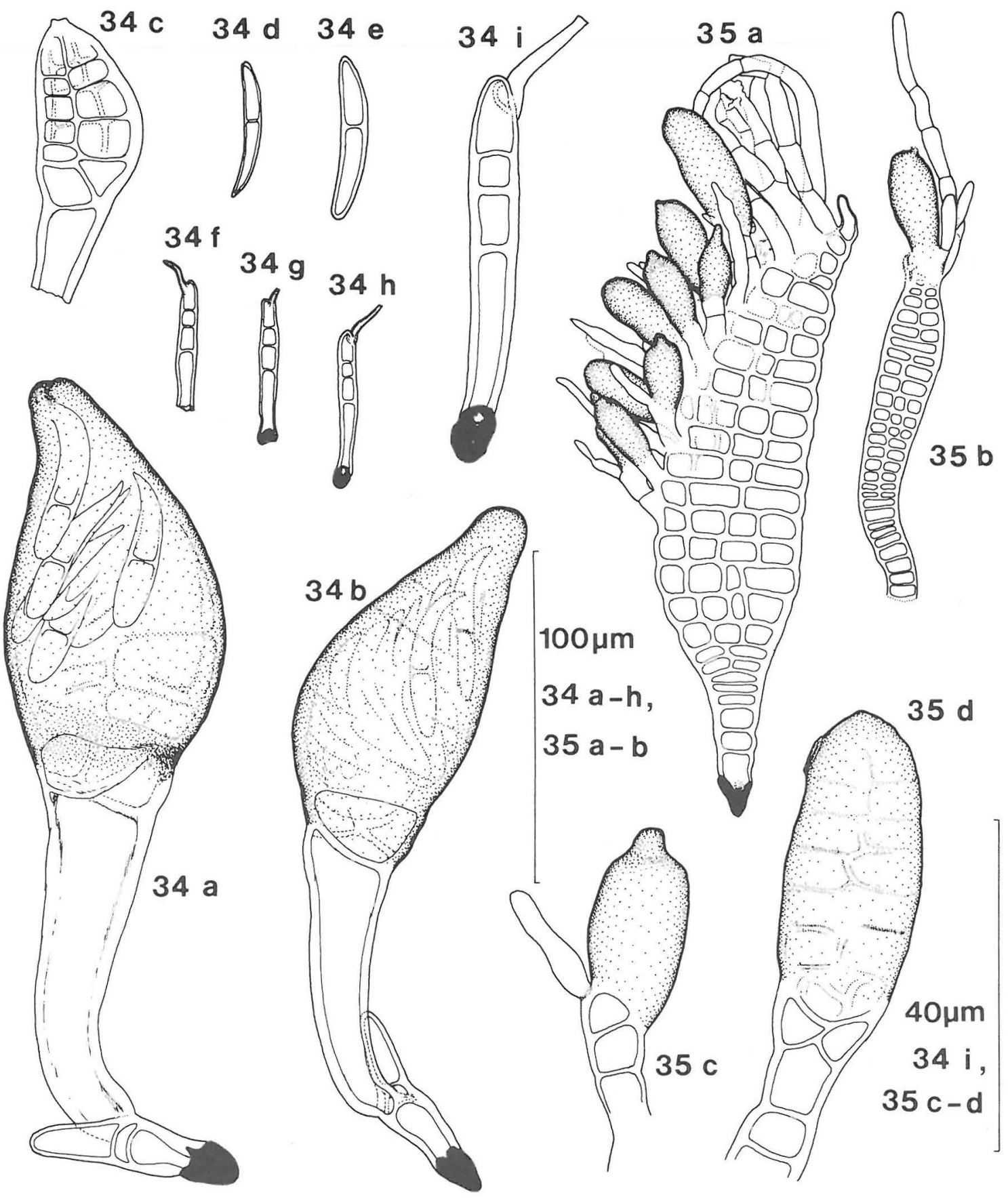

Figs. 34-35. - 34: Dioicomyces anthici, a)-b) female specimens, c) immature perithecium, d) male spore, e) female spore, f)-i) male specimens. a), c)-g) from Anthicus floralis, b), h)-i) from Anthicus formicarius. - 35: Euzodiomyces lathrobii from Lathrobium longulum, a)-b) mature specimens, c)-d) perithecia, secondary stalk cells visible in d). 


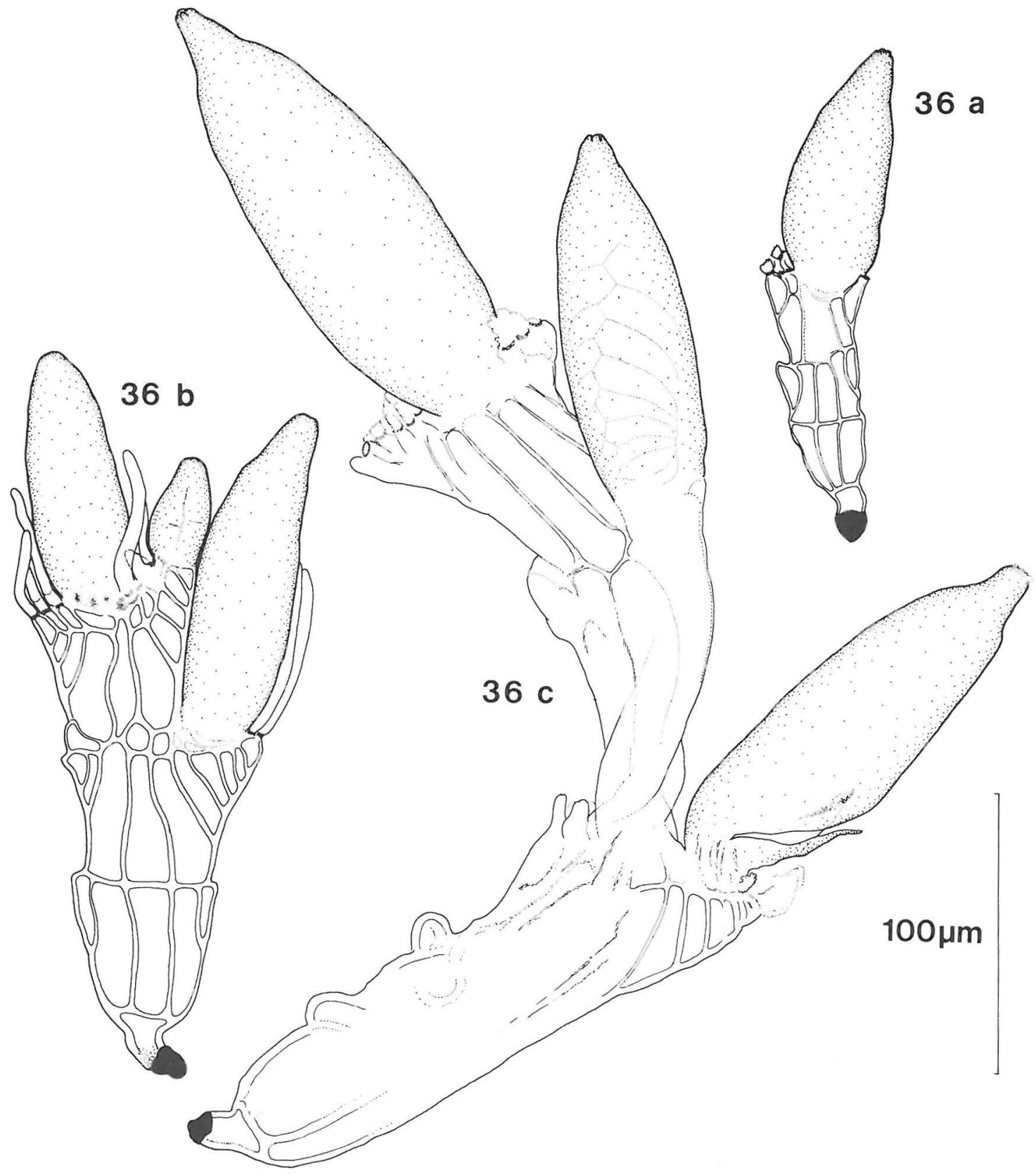

Fig. 36. Peyritschiella protea, a)-b) from Anotylus insecatus, c) from Anotylus rugosus. 

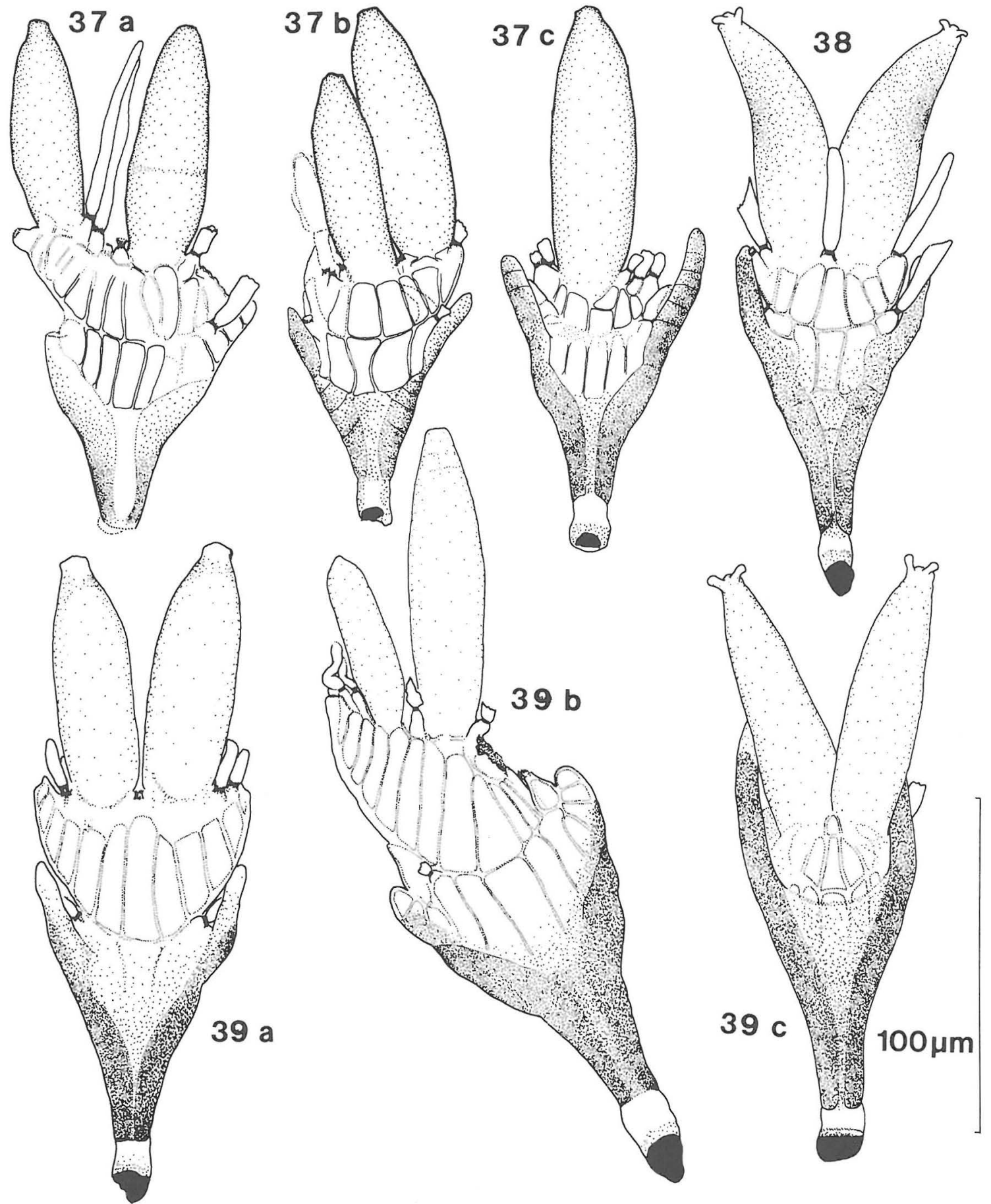

Figs. 37-39. - 37: Dichomyces nigrescens from Philonthus debilis, a)-c) variation of thallus. - 38: Dichomyces furcifer subsp. subarcticus n.subsp. from Philonthus albipes, holotype. - 39: Dichomyces furcifer, a) from Philonthus discoideus, b) from Philonthus umbratilis, c) auriculate morph from Philonthus puella. 


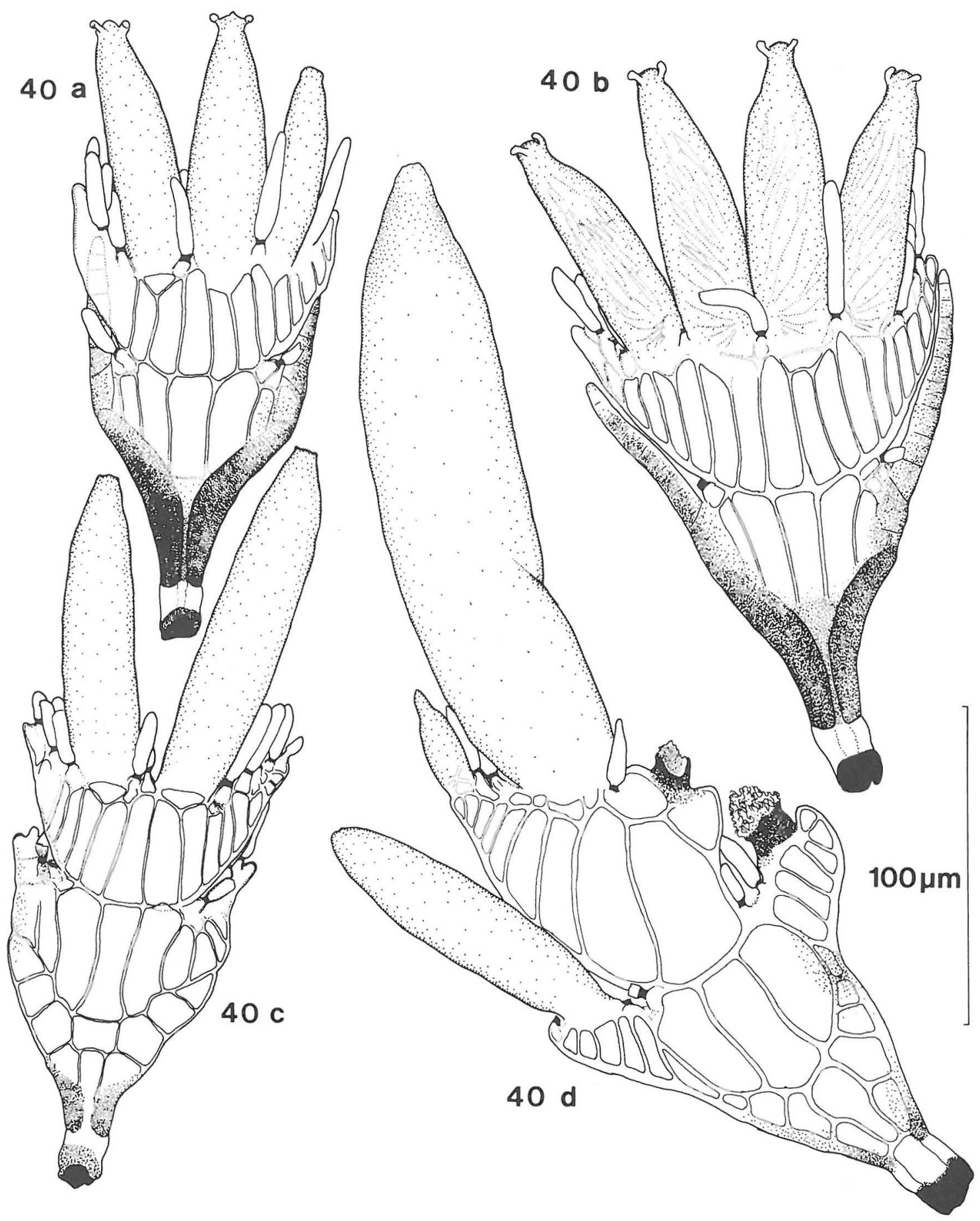

Fig. 40. Dichomyces vulgatus, a)-b) auriculate morphs from Philonthus longicornis, c) non-auriculate morph from Philonthus longicornis, d) non-auriculate morph from Philonthus cephalotes. 


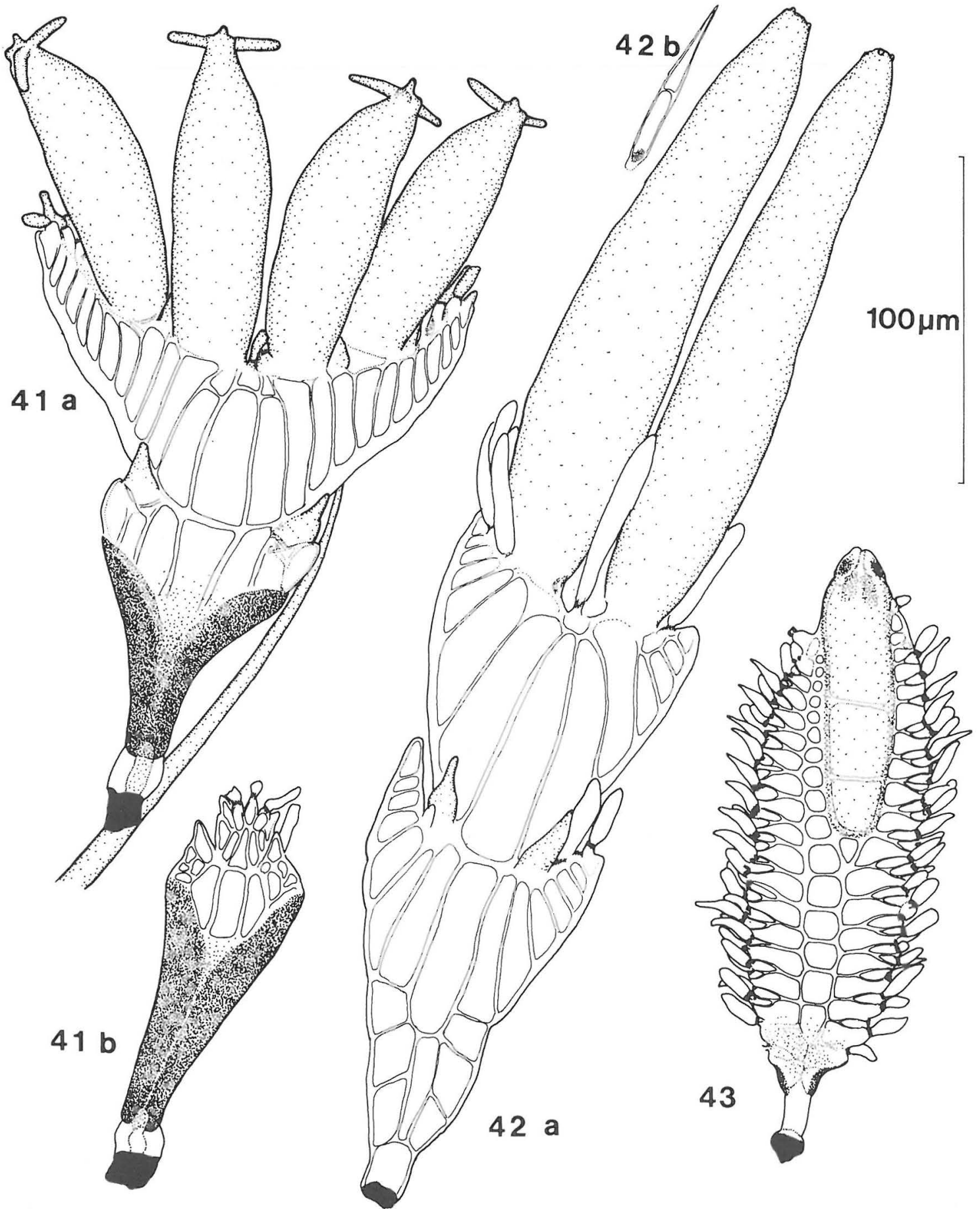

Figs. 41-43. - 41: Dichomyces biformis from Philonthus umbratilis, a) mature specimen on a seta of the host, b) immature specimen. - 42: Dichomyces princeps from Philonthus cephalotes, a) mature specimen, b) germinating spore. - 43: Rickia peyerimhoffii from Scaphisoma agaricinum. 


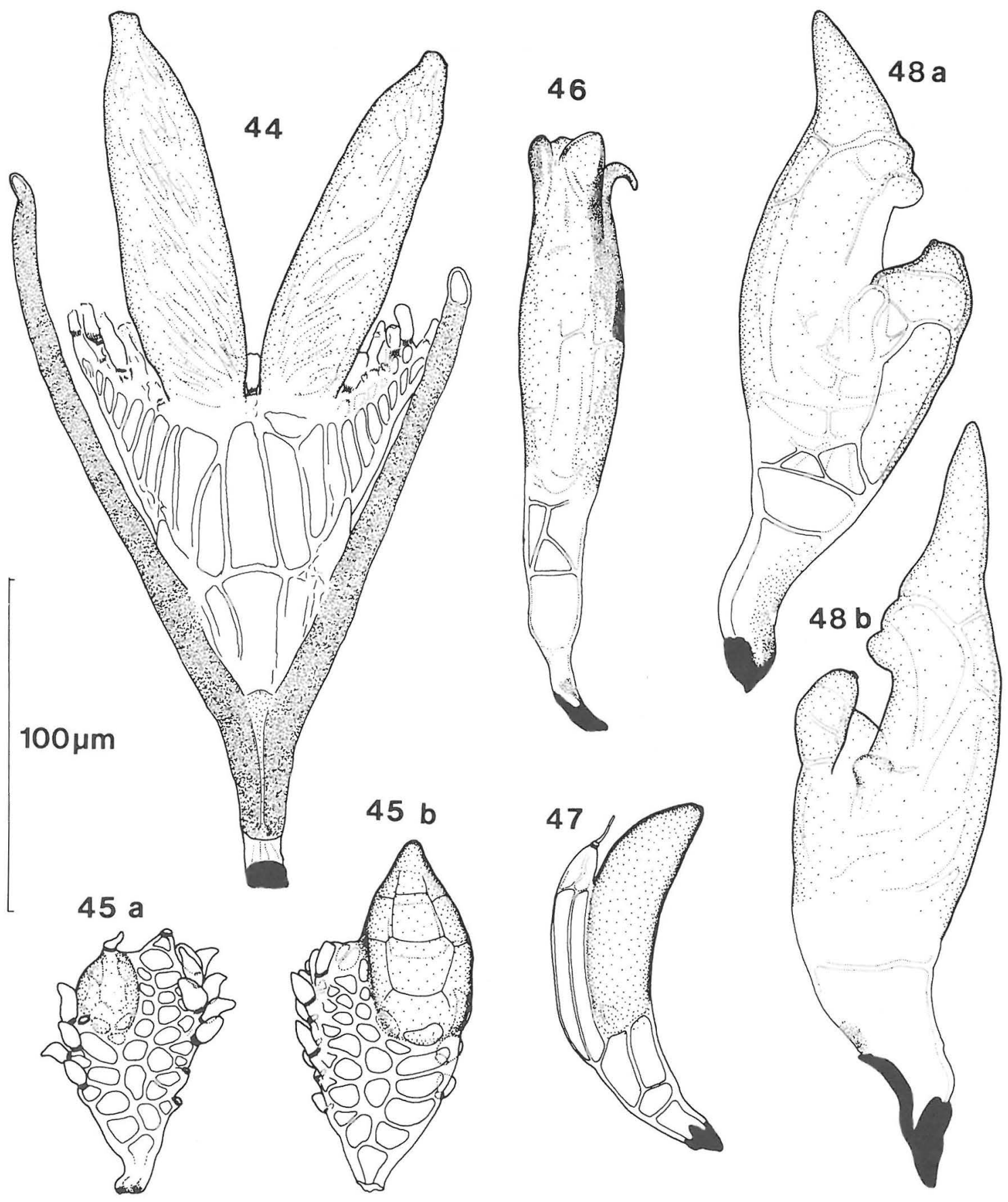

Figs. 44-48. - 44: Dichomyces hybridus from Philonthus ventralis. - 45: Rickia hyperborea from Micralymma marinum, a) immature specimen, b) mature specimen. - 46: Chitonomyces melanurus from Laccophilus minutus. 47: Chitonomyces bidessarius from Hygrotus inaequalis. - 48: Chitonomyces paradoxus from Laccophilus minutus, a)-b) variation of thallus. 


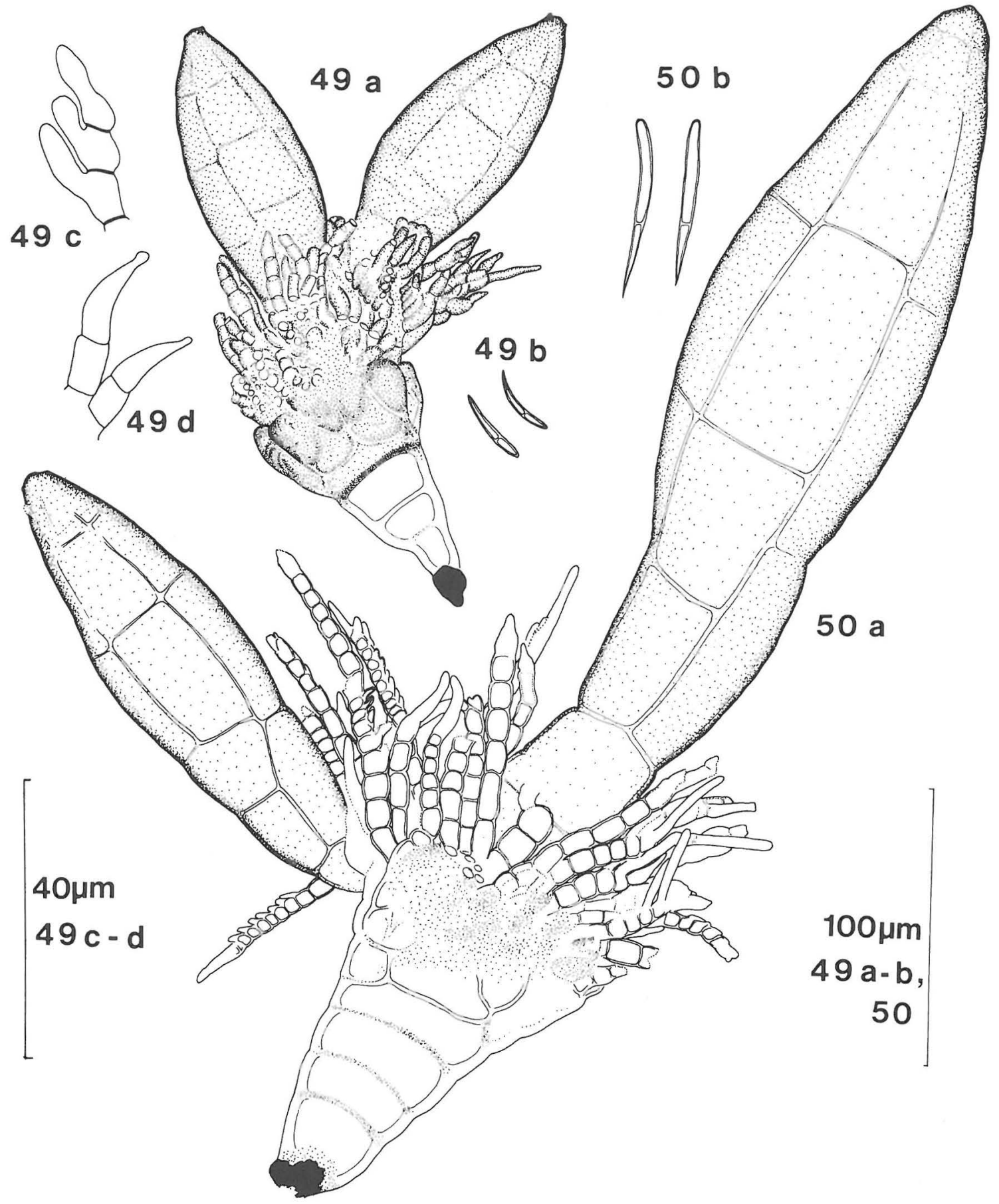

Figs. 49-50. - 49: Symplectromyces lapponicus n.sp. from Quedius boops, a) holotype, b) spores, c) branch with three antheridia, d) beak-like cells from appendage branch. - 50: Symplectromyces vulgaris from Quedius mesomelinus, a) mature specimen (perithecial stalk cell with an additional septum), b) spores. 


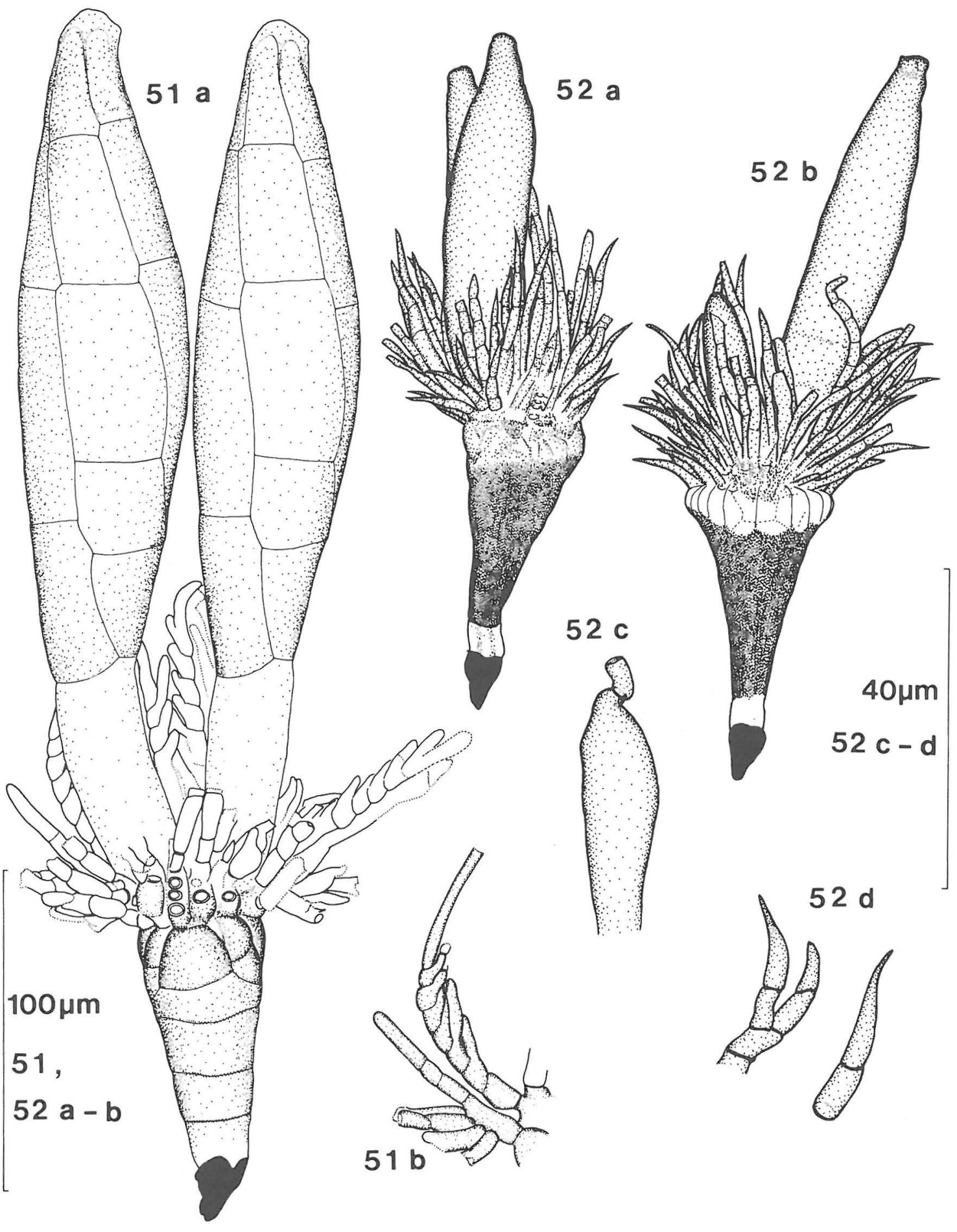

Figs. 51-52. - 51: Symplectromyces rarus n.sp. from Quedius fuliginosus, a) holotype, b) appendage branches, upper one with antheridia. - 52: Teratomyces brevicaulis from Erichsonius cinerascens, a)-b) mature specimens, c) young perithecium with base of trichogyne, d) beak-like cells from appendage branches. 


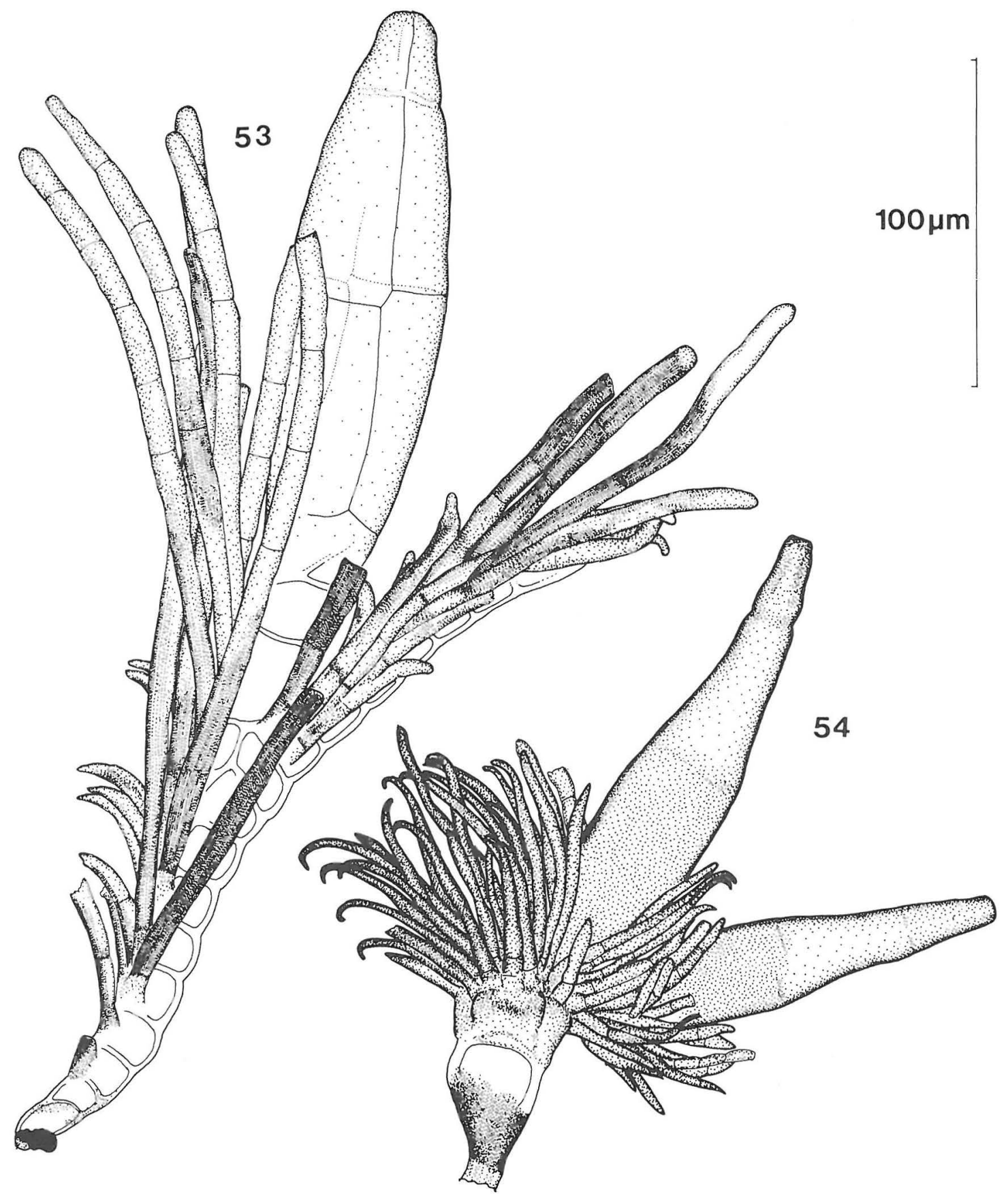

Figs. 53-54. - 53: Rhachomyces furcatus from Othius punctulatus. - 54: Teratomyces philonthi from Gabrius trossulus. 


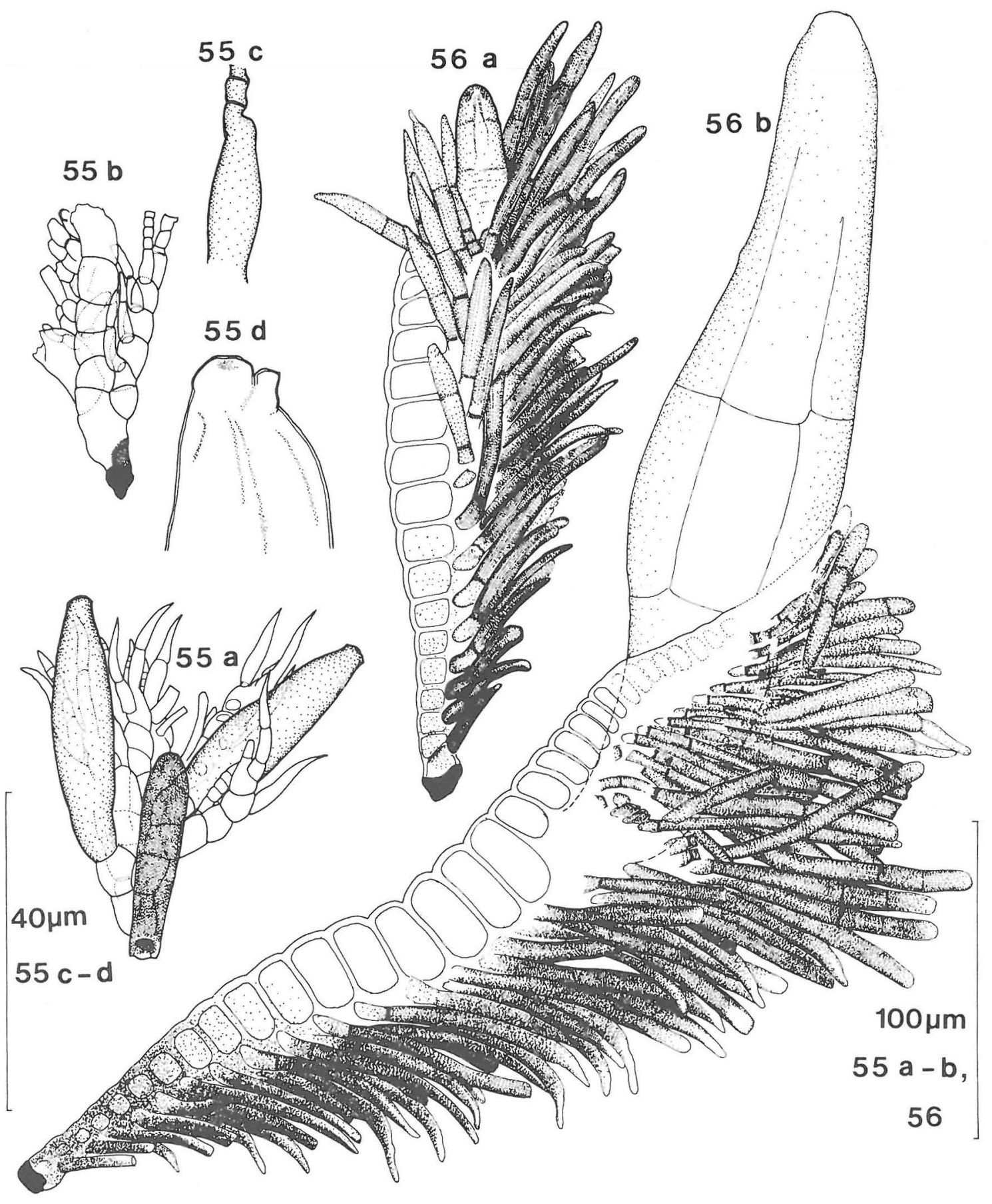

Figs. 55-56. - 55: Diplomyces clavifer from Erichsonius cinerascens, a) typical specimen, b) specimen with poorly developed outgrowth from base of receptacle (appendages and perithecium broken), c) young perithecium with base of trichogyne, d) apex of mature perithecium. 56: Rhachomyces philonthinus from Philonthus fulvipes, a) mature specimen (base of perithecium only weakly indicated in front of appendages), b) immature specimen. 

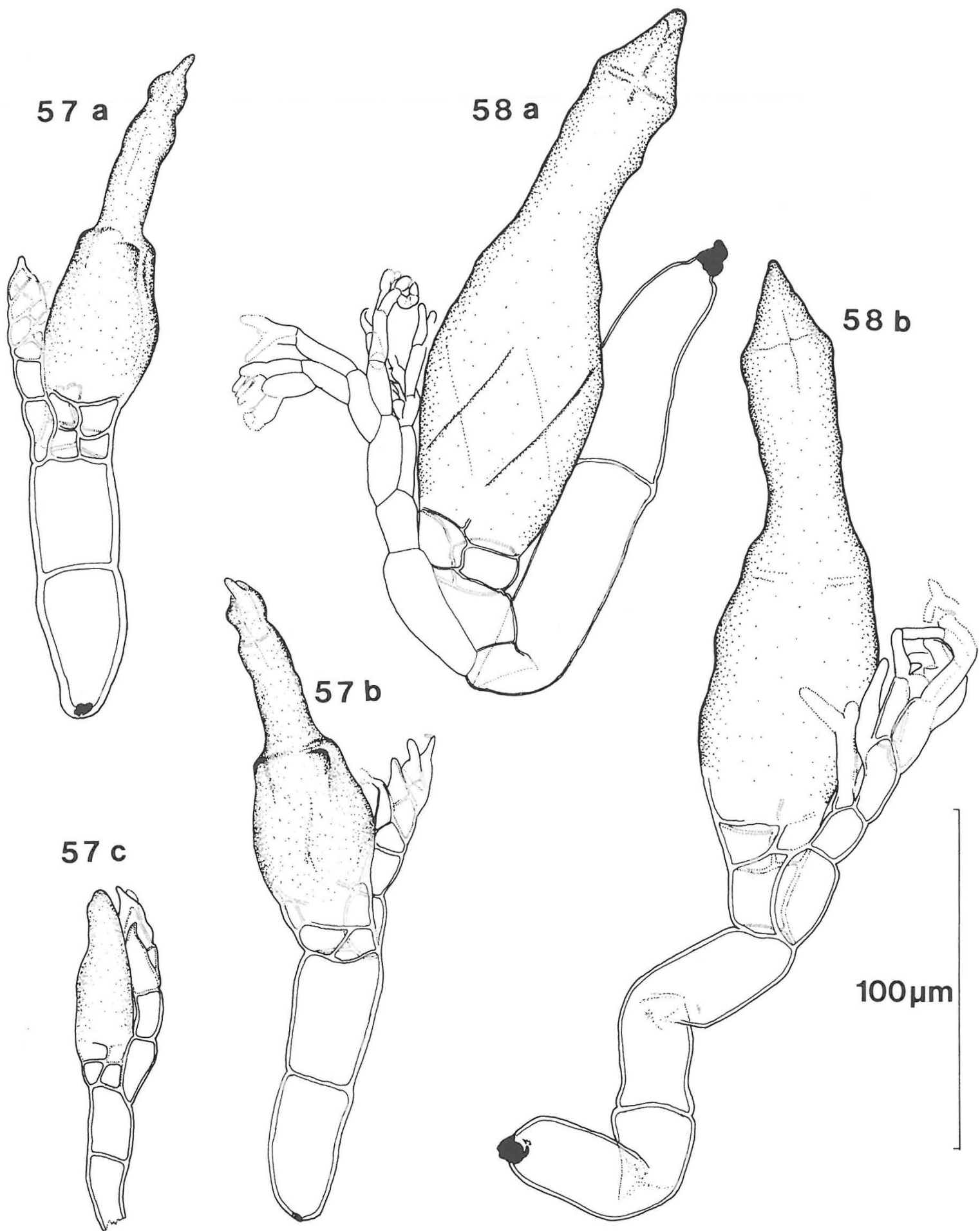

Figs. 57-58. - 57: Stigmatomyces hydrelliae, a) from Hydrellia flaviceps, b) from H. griseola, c) immature specimen from Hydrellia incana. - 58: Fanniomyces copromyzae n.sp. from Copromyza borealis, a)-b) mature specimens. a) holotype. 


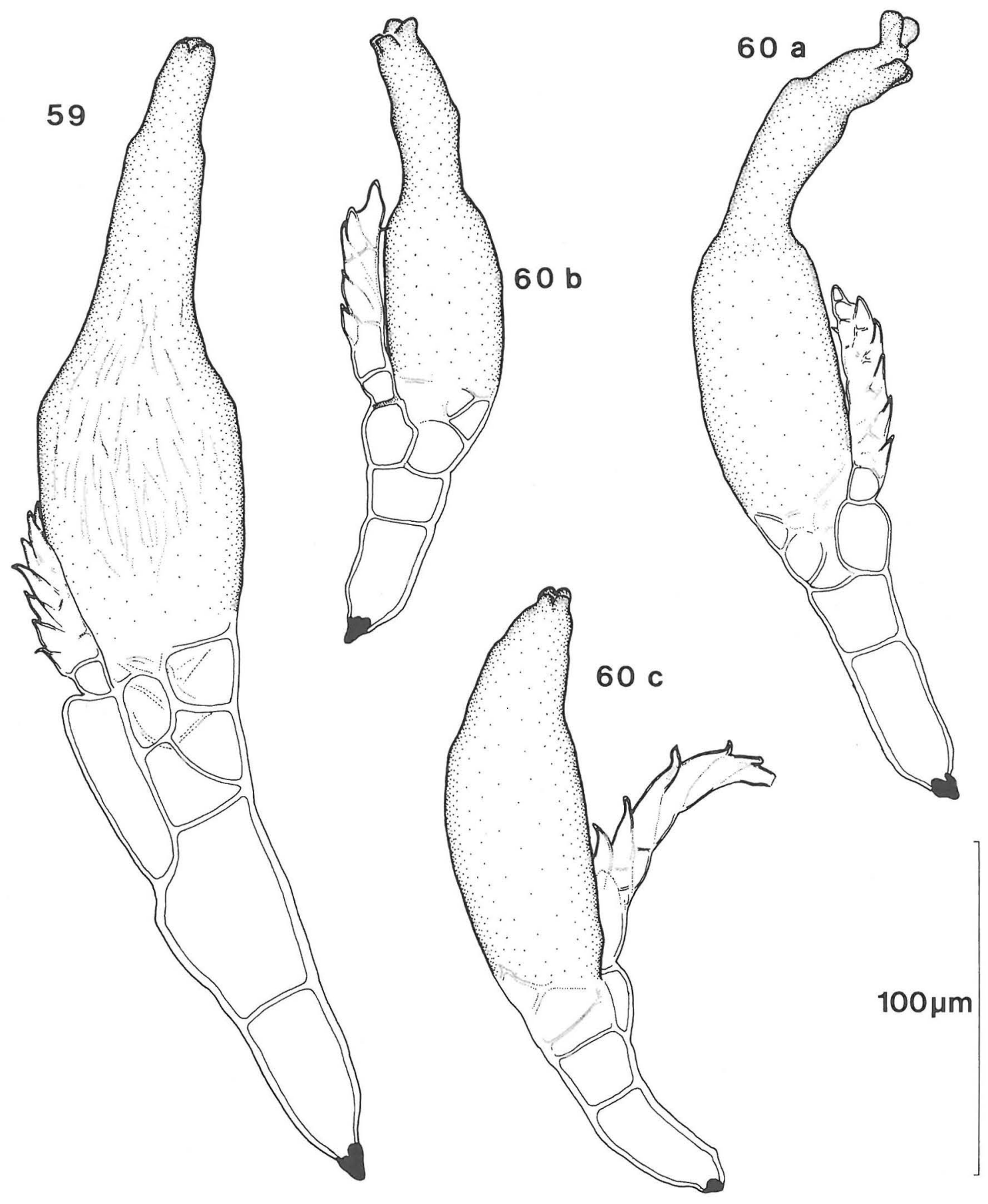

Figs. 59-60. - 59: Stigmatomyces dichaetae n.sp. from Dichaeta caudata, holotype. -60: Stigmatomyces mantis n.sp. from Ochthera mantis, a)-c) variation of thallus. a) holotype. 


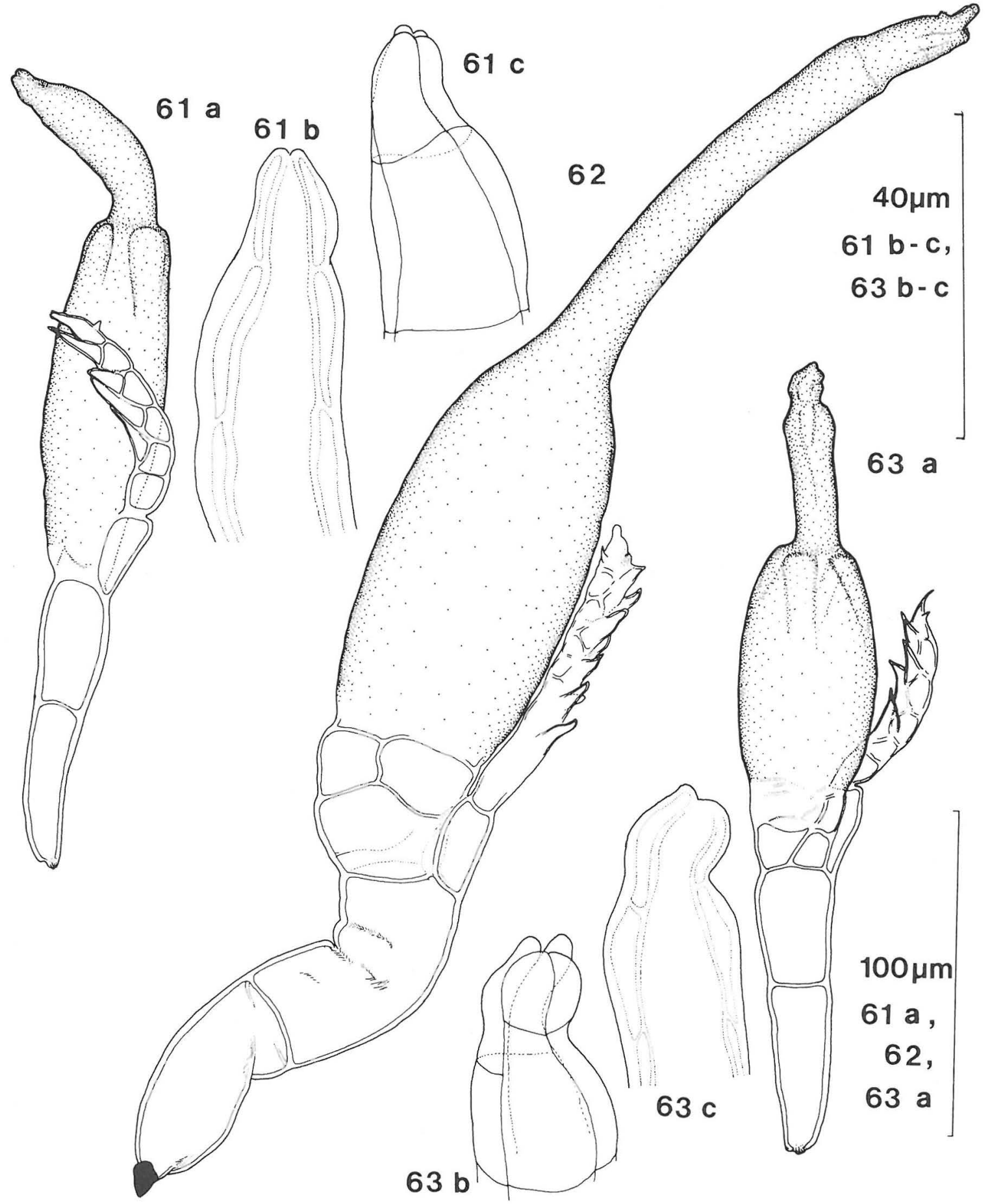

Figs. 61-63. - 63: Stigmatomyces ephydrae from Ephydra riparia, a) mature specimen, b) section through tip of perithecium, c) cell arrangements of tip of perithecium. - 62: Stigmatomyces manicatae n.sp. from Ochthera manicata, holotype. -63: Stigmatomyces bottnica n.sp. from Ephydra scholtzi, a) holotype, b) cell arrangement of tip perithecium, c) section through tip of perithecium. 


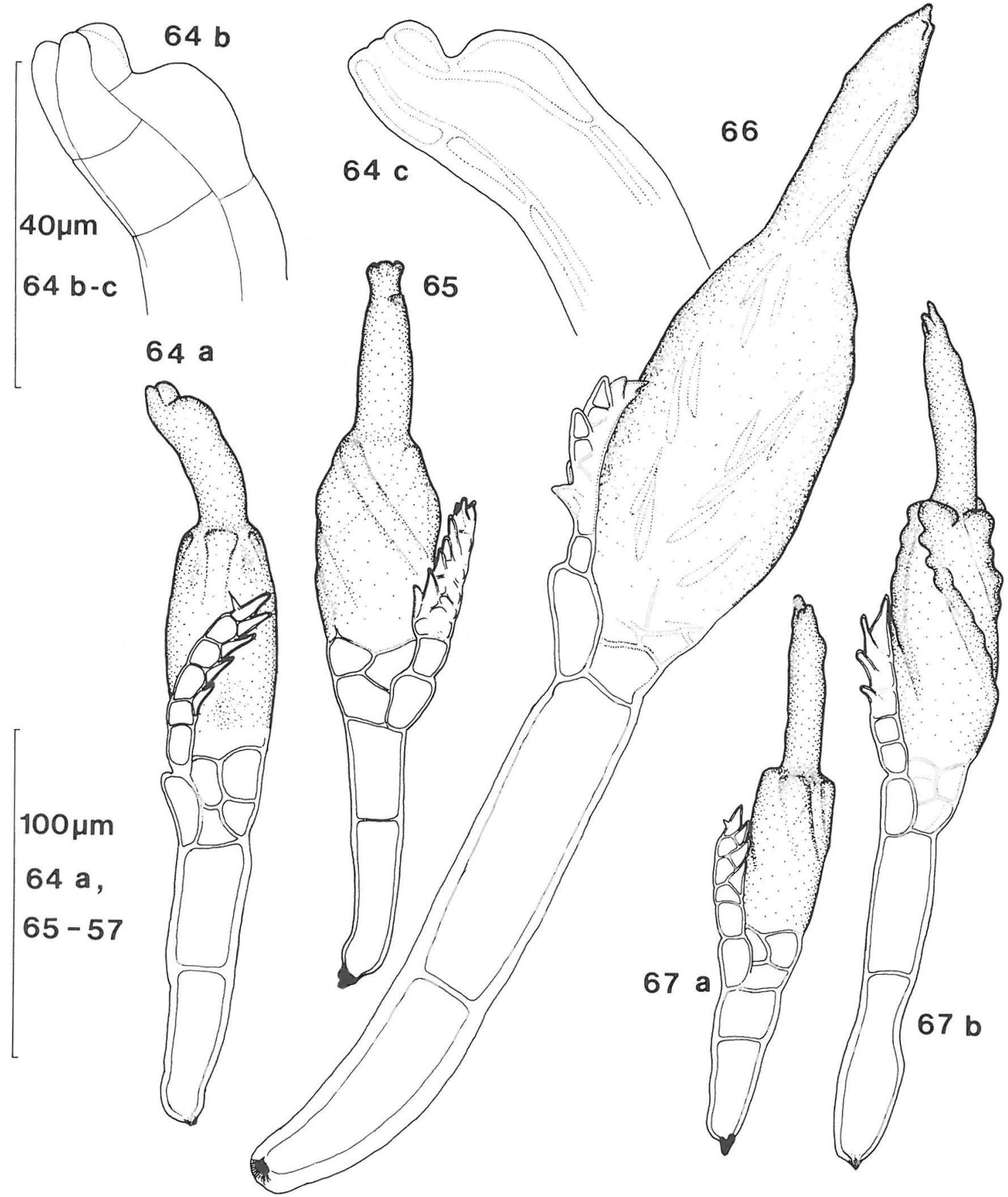

Figs. 64-67. - 64: Stigmatomyces setacerae n.sp. from Setacera micans, a) holotype, b) cell arrangement of tip of perithecium, c) section through tip of perithecium. - 65: Stigmatomyces axystae n.sp. from Axysta cesta, holotype. - 66: Stigmatomyces baeri from Musca domestica. - 67: Stigmatomyces purpureus from a) Scatella stagnalis, b) Scatella callosicosta. 


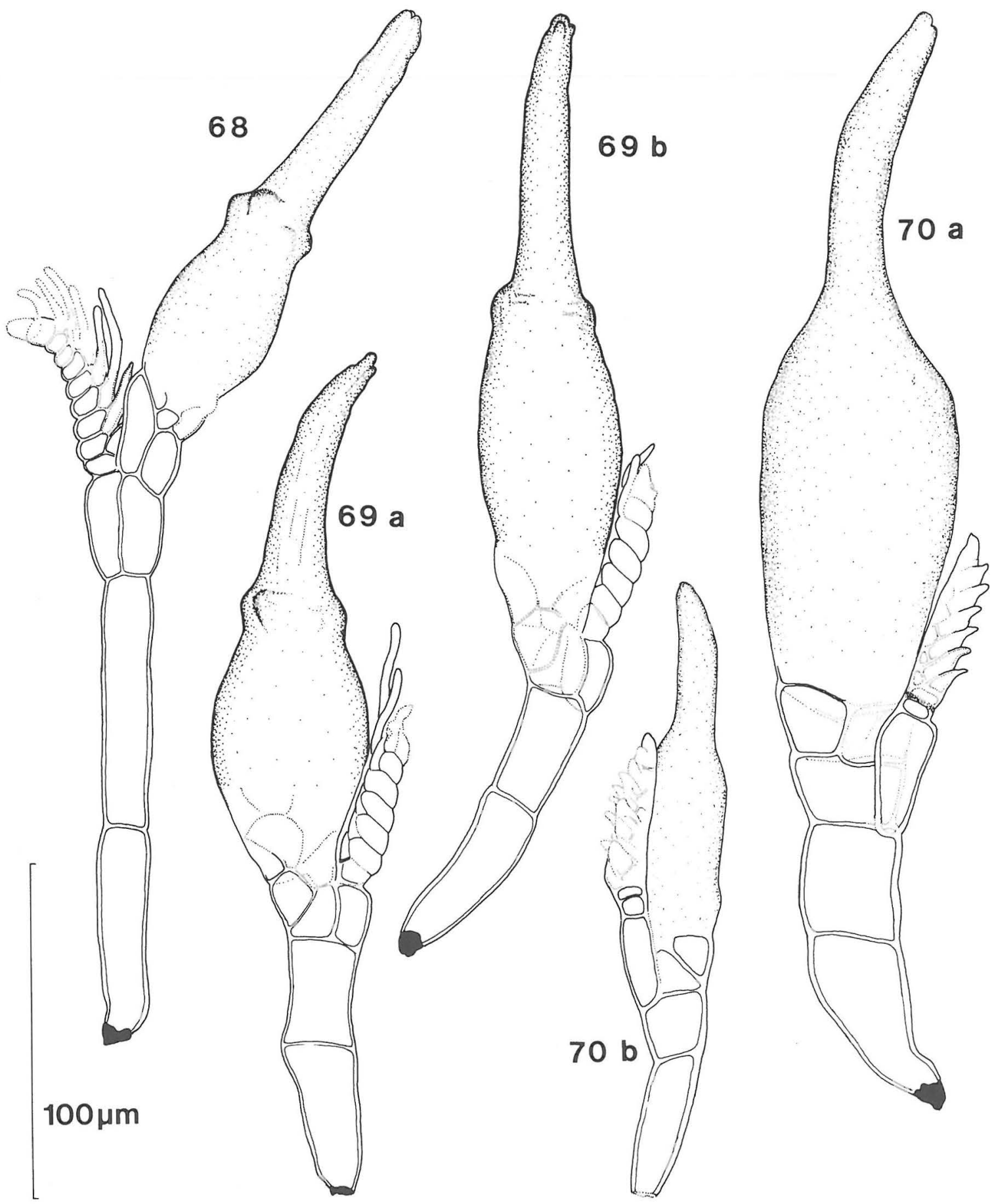

Figs. 68-70. - 68: Stigmatomyces subterraneus n.sp. from Limosina talparum, holotype. - 69: Stigmatomyces chthonicus n.sp. from Limosina claviventris, a)-b) variation of thallus. a) holotype. - 70: Stigmatomyces scaptomyzae from Scaptomyza pallida, a) mature specimen, b) immature specimen. 


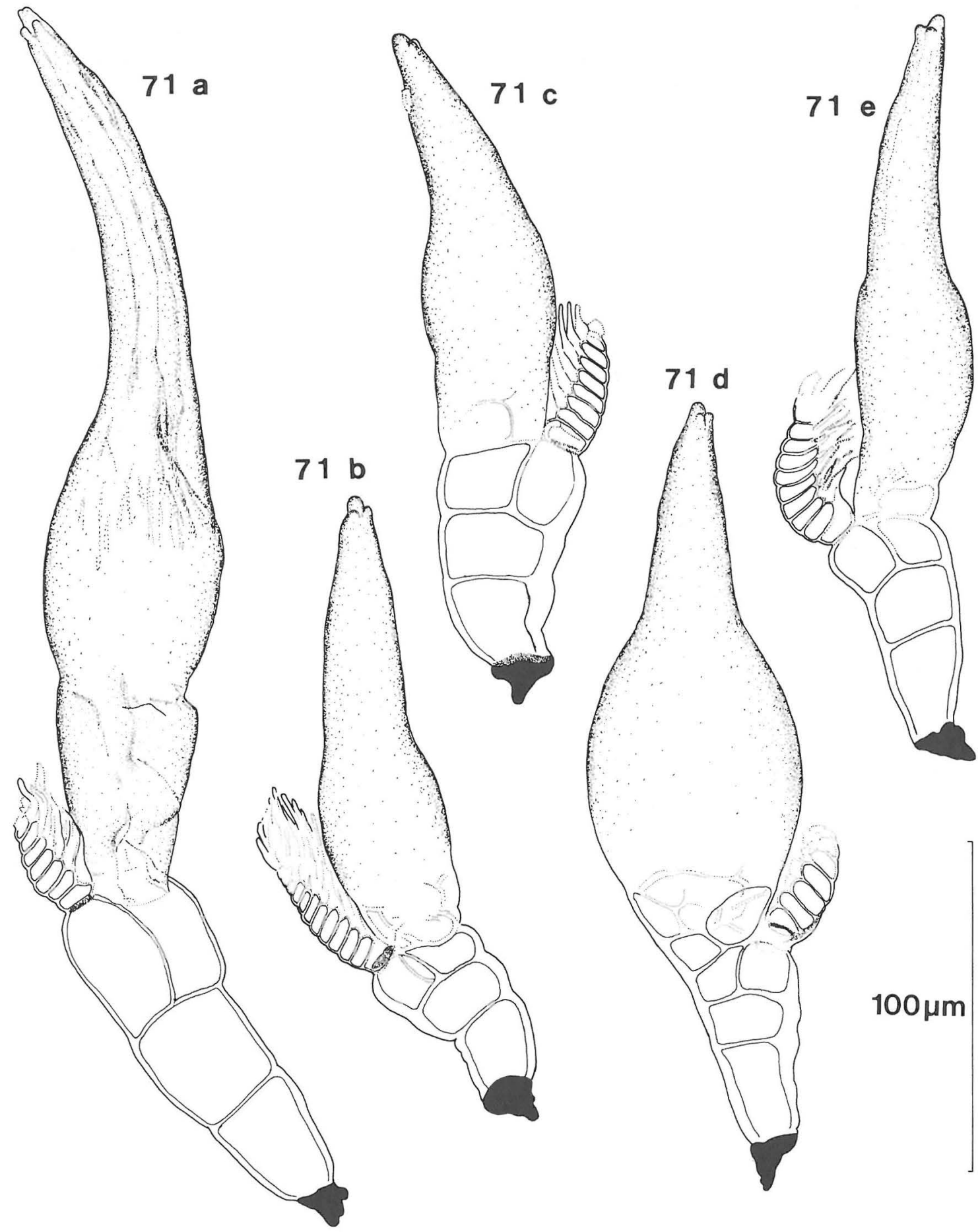

Fig. 71. Stigmatomyces hackmanii n.sp. from Limosina schmitzi, a) from the leg of the host, b)-e) from the wing of the host. d) holotype. 


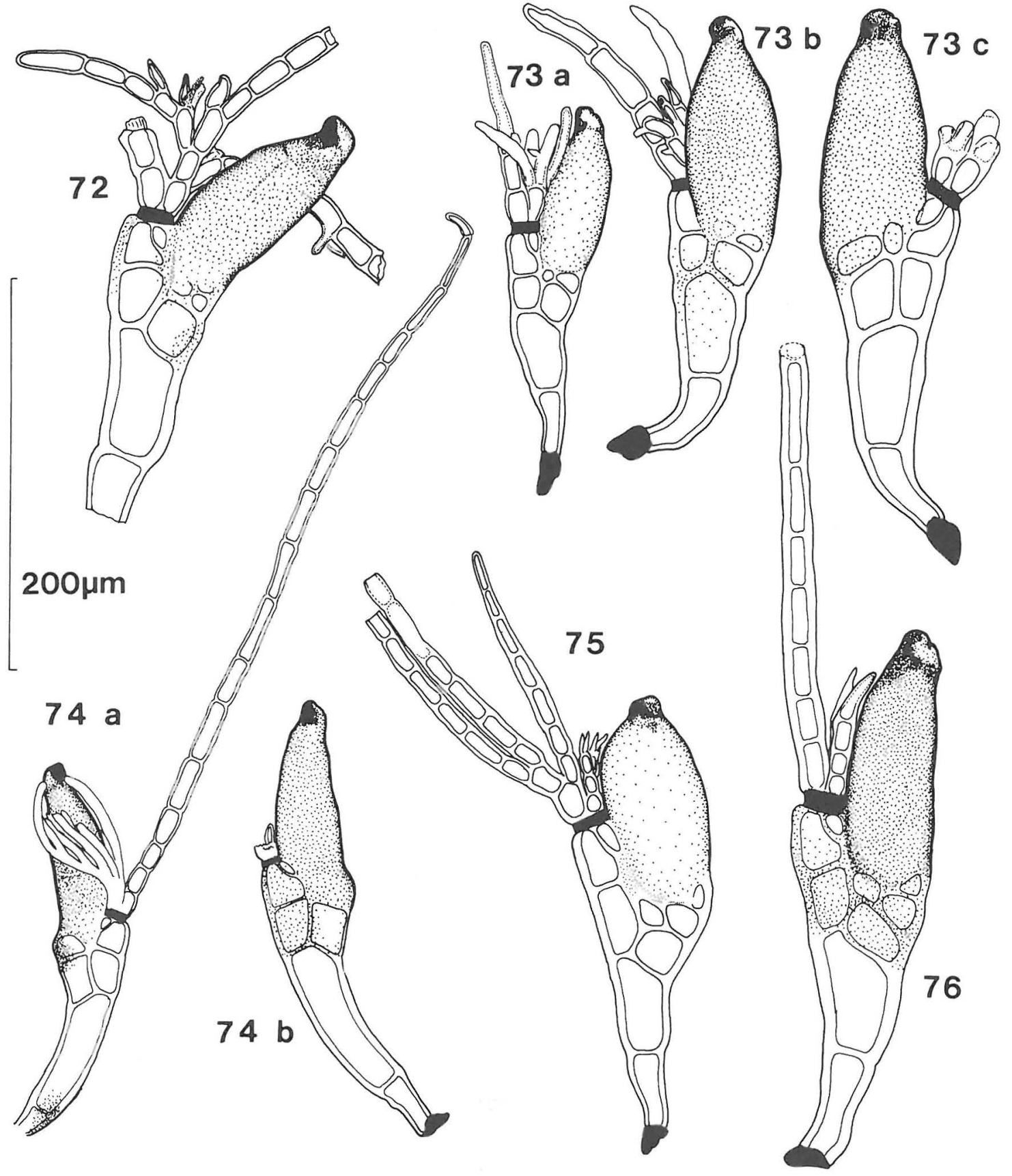

Figs. 72-76. - 72: Laboulbenia elaphri from Elaphrus cupreus. - 73: Laboulbenia polyphaga, a)-b) from Calathus micropterus, c) from Calathus erratus. - 74: Laboulbenia metableti from Syntomus truncatellus, a)-b) mature specimens, b) with broken appendages. - 75: Laboulbenia ophoni from Harpalus xanthopus winkleri. - 76: Laboulbenia bradycelli from Trichocellus placidus. 

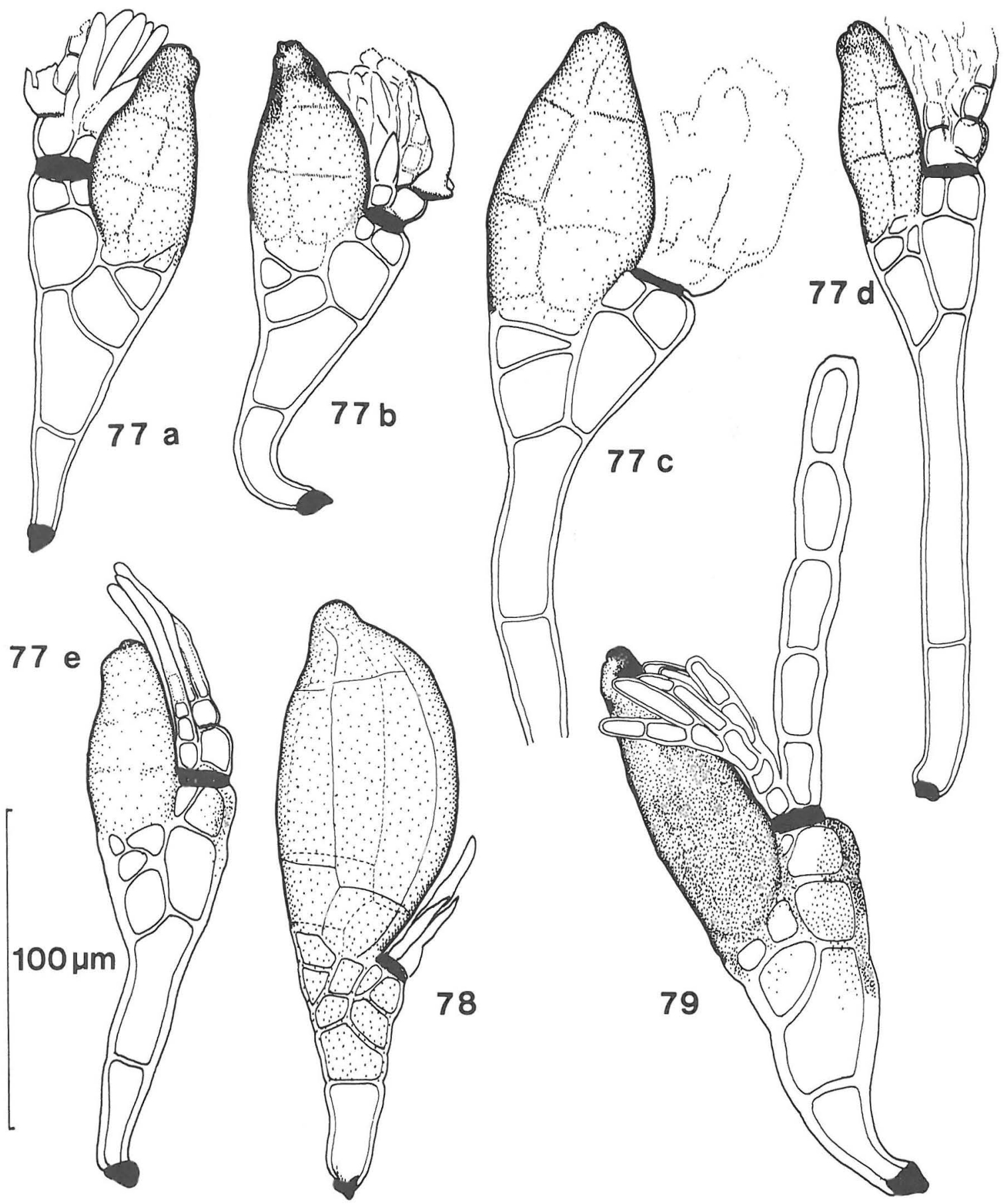

Figs. 77-79. - 77: Laboulbenia pedicellata from a)-b) Bembidion quadrimaculatum, c) Bembidion articulatum, d) Bembidion doris; e) immature specimen from Dyschirius septentrionum. - 78: Laboulbenia curtipes from Bembidion varium. - 79 : Laboulbenia pulchella from Dromius linearis. 


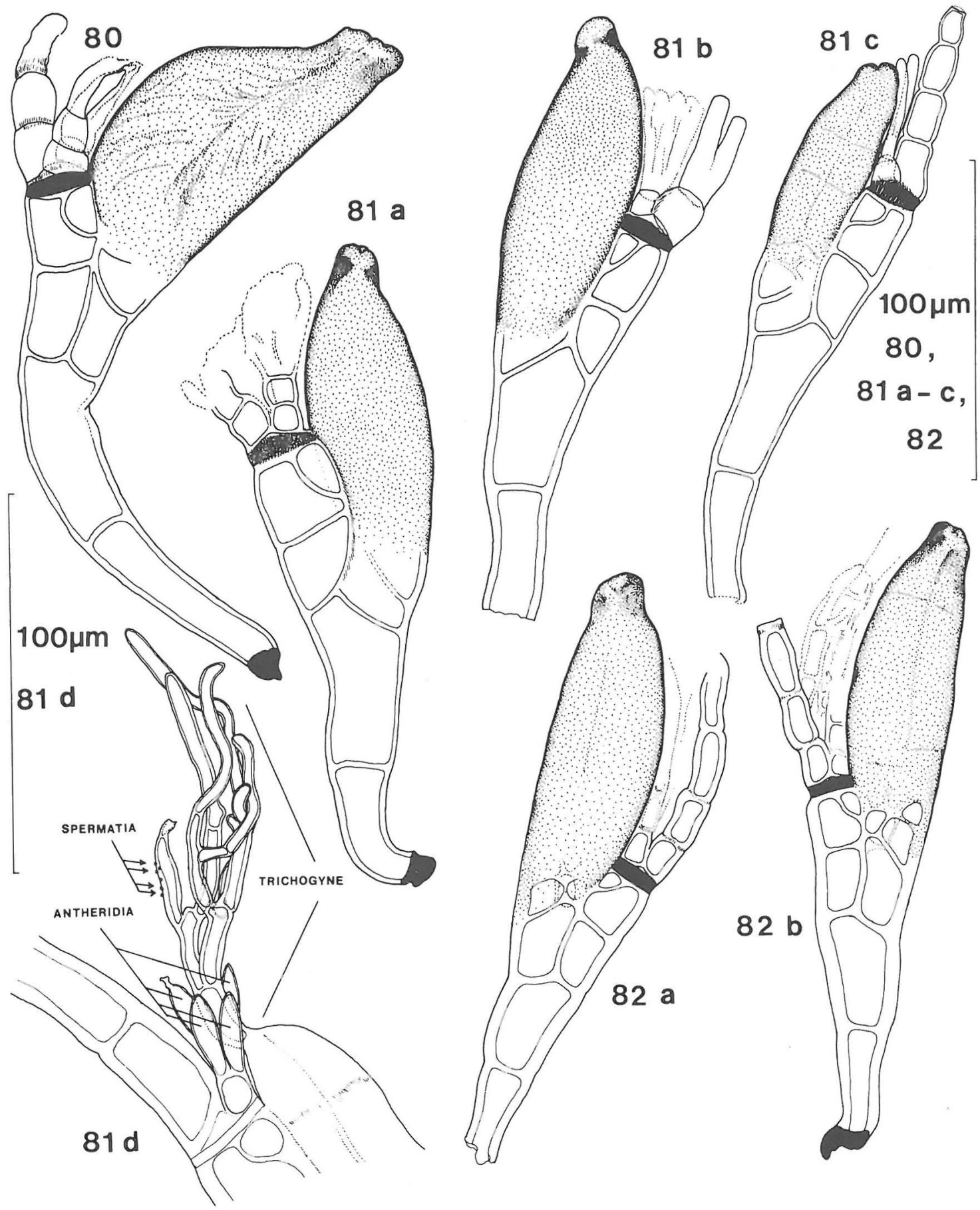

Figs. 80-82. - 80: Laboulbenia murmanica n.sp. from Bembidion transparens, holotype. - 81: Laboulbenia vulgaris, a)-b) from Bembidion bruxellense, c) from Bembidion tetracolum, d) from Trechus rubens, upper part of young thallus. - 82: Laboulbenia giardii from Dicheirotrichus rufithorax. 


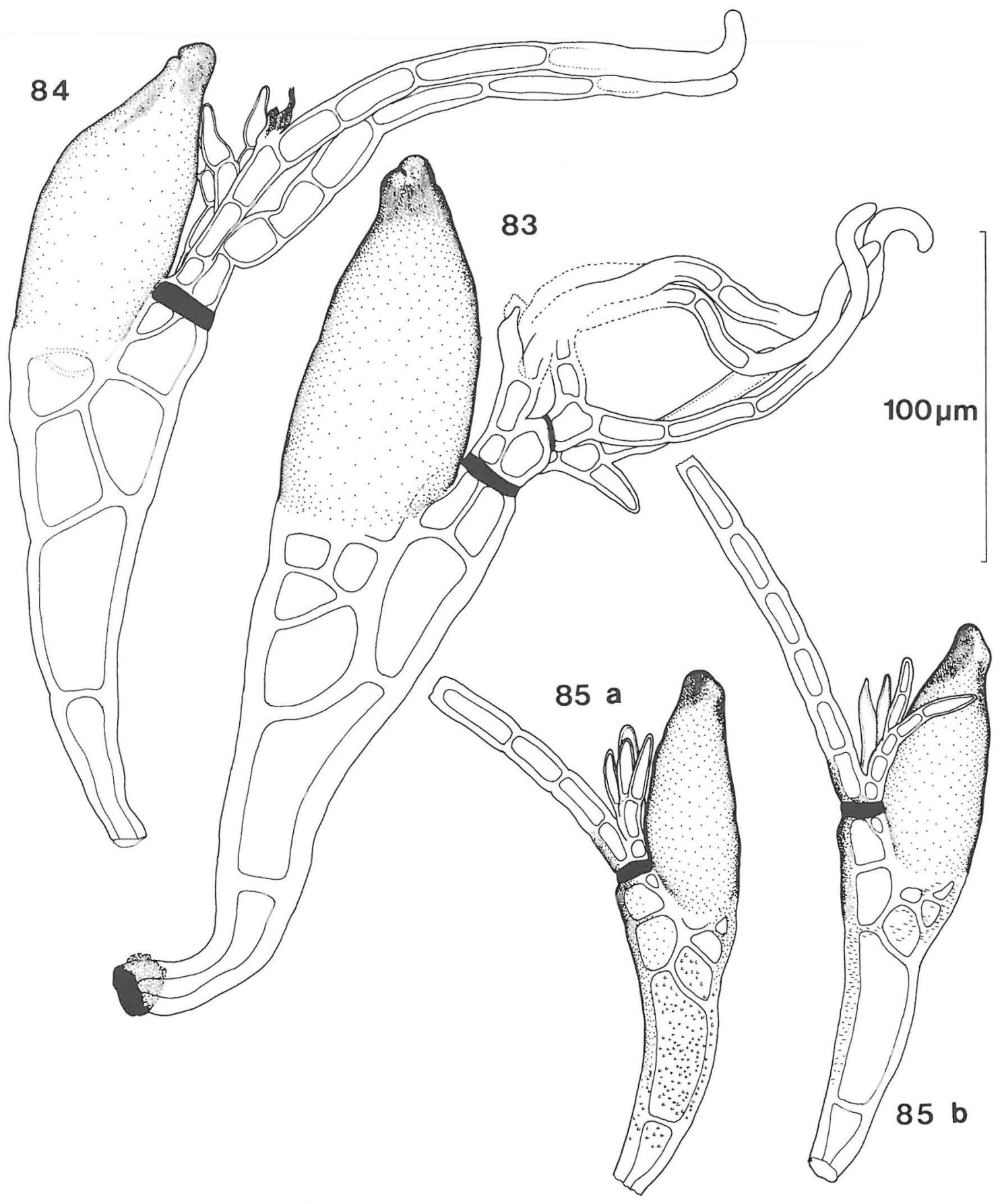

Figs. 83-85. - 83: Laboulbenia clivinalis from Clivina fossor. - 84: Laboulbenia leisti from Leistus ferrugineus. - 85: Laboulbenia notiophili from a) Notiophilus germinyi, b) Notiophilus biguttatus. 


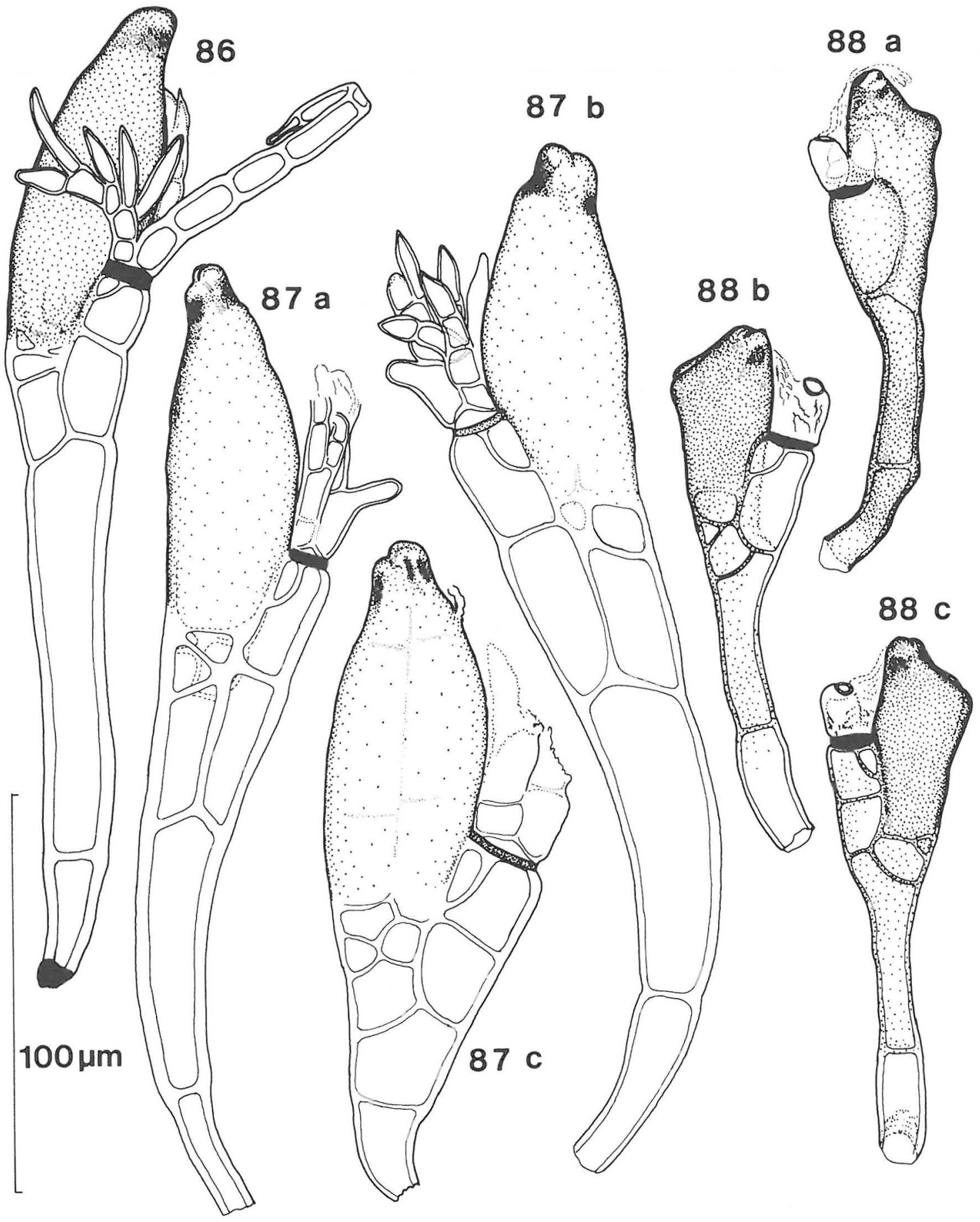

Figs. 86-88. - 86: Laboulbenia stilicicola from Stilicus similis. - 87: Laboulbenia manubriolata, a) mature specimen, b) nearly mature specimen with unbroken appendage and antheridia, c) short specimen from the leg of the host. From Perigona nigriceps. - 88: Laboulbenia carelica n.sp. from Bembidion doris, a)-c) three overmature specimens. a) holotype. 

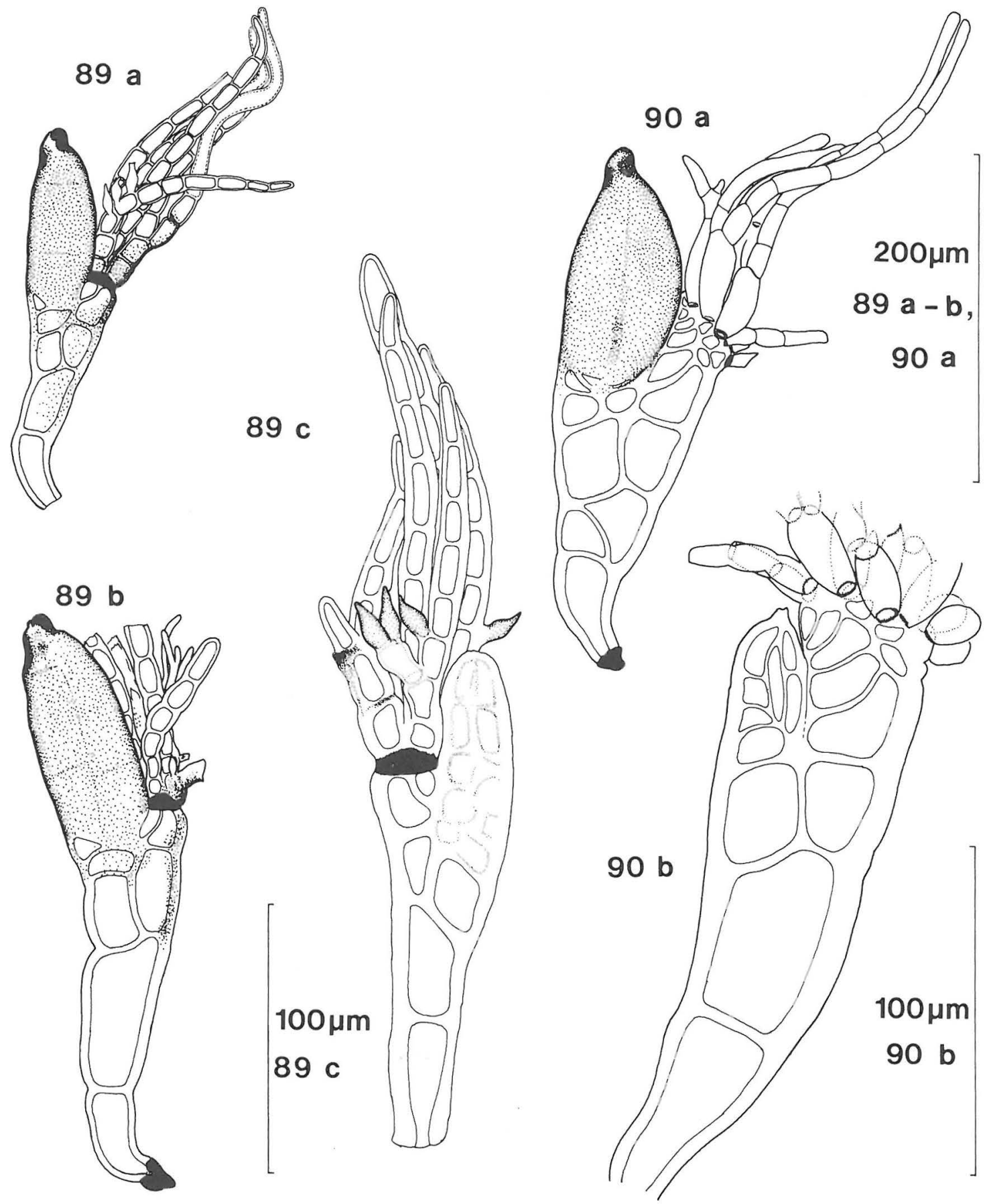

Figs. 89-90. - 89: Laboulbenia flagellata, a)-b) from Agonum marginatum, c) from Agonum dorsale. b) immature specimen. -90: Laboulbenia fasciculata from Patrobus assimile, a) mature specimen, b) immature specimen. 


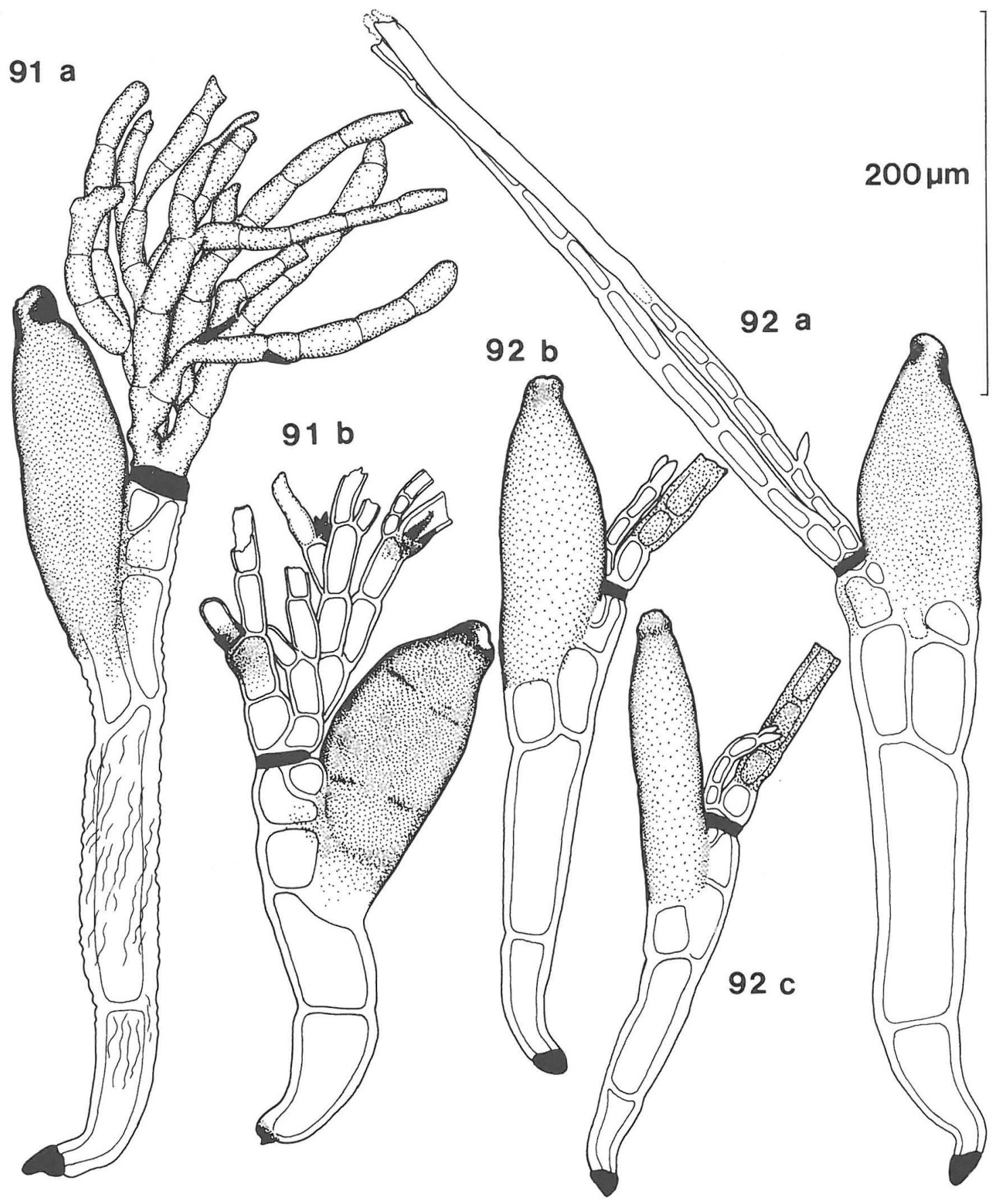

Figs. 91-92. - 91: Laboulbenia pseudomasei from Pterostichus nigrita, a) long striated variant, b) typical specimen. - 92: Laboulbenia argutoris from Pterostichus diligens, a) specimen with long inner appendage, b)-c) typical specimens. 


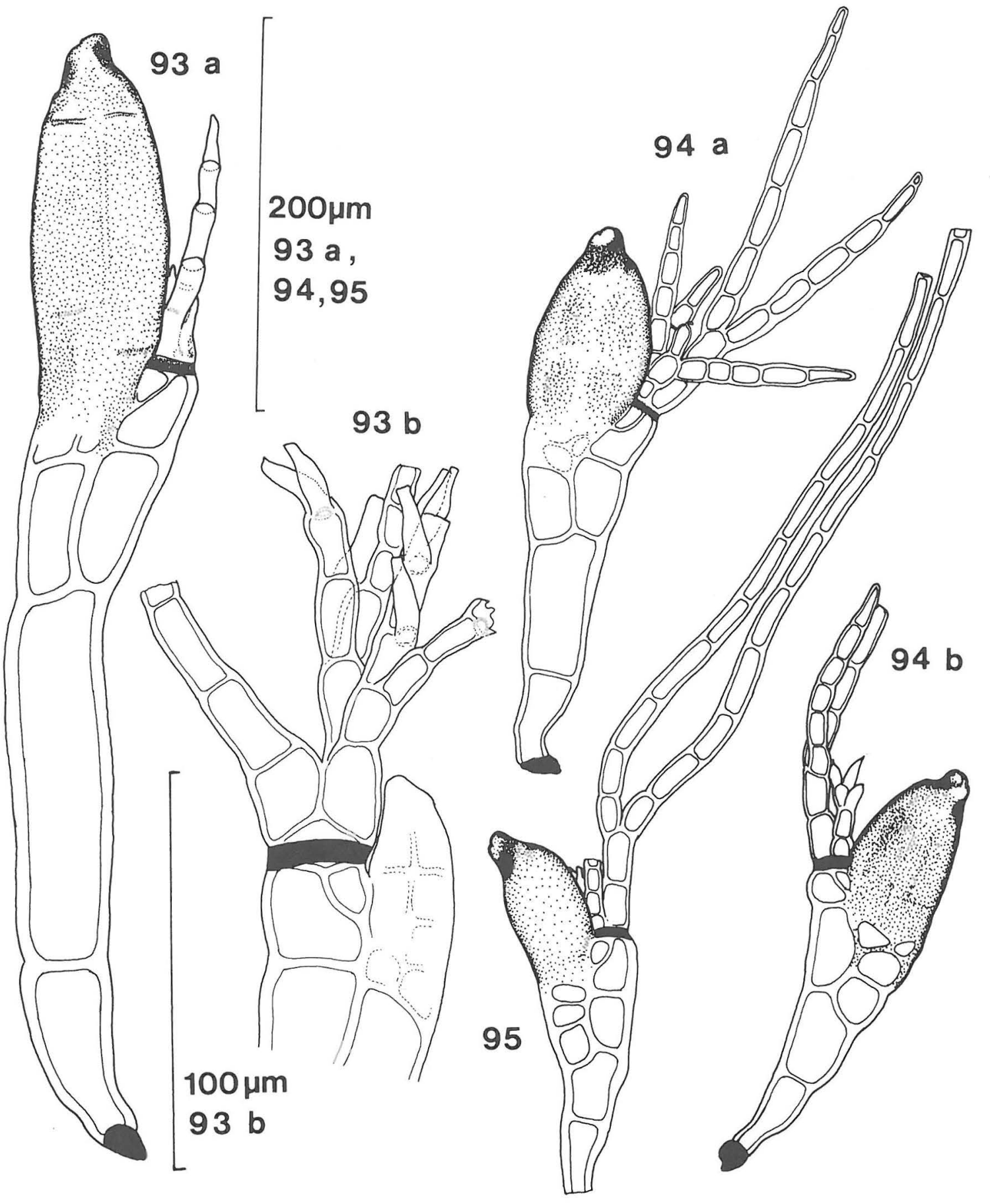

Figs. 93-95. - 93: Laboulbenia oodiphila n.sp. from Oodes helopioides, a) holotype (with damaged appendage), b) immature specimen with slightly damaged appendage, antheridia visible. - 94: Laboulbenia compressa from a) Harpalus affinis, b) Harpalus xanthopus winkleri. - 95: Laboulbenia filifera from Harpalus affinis. 


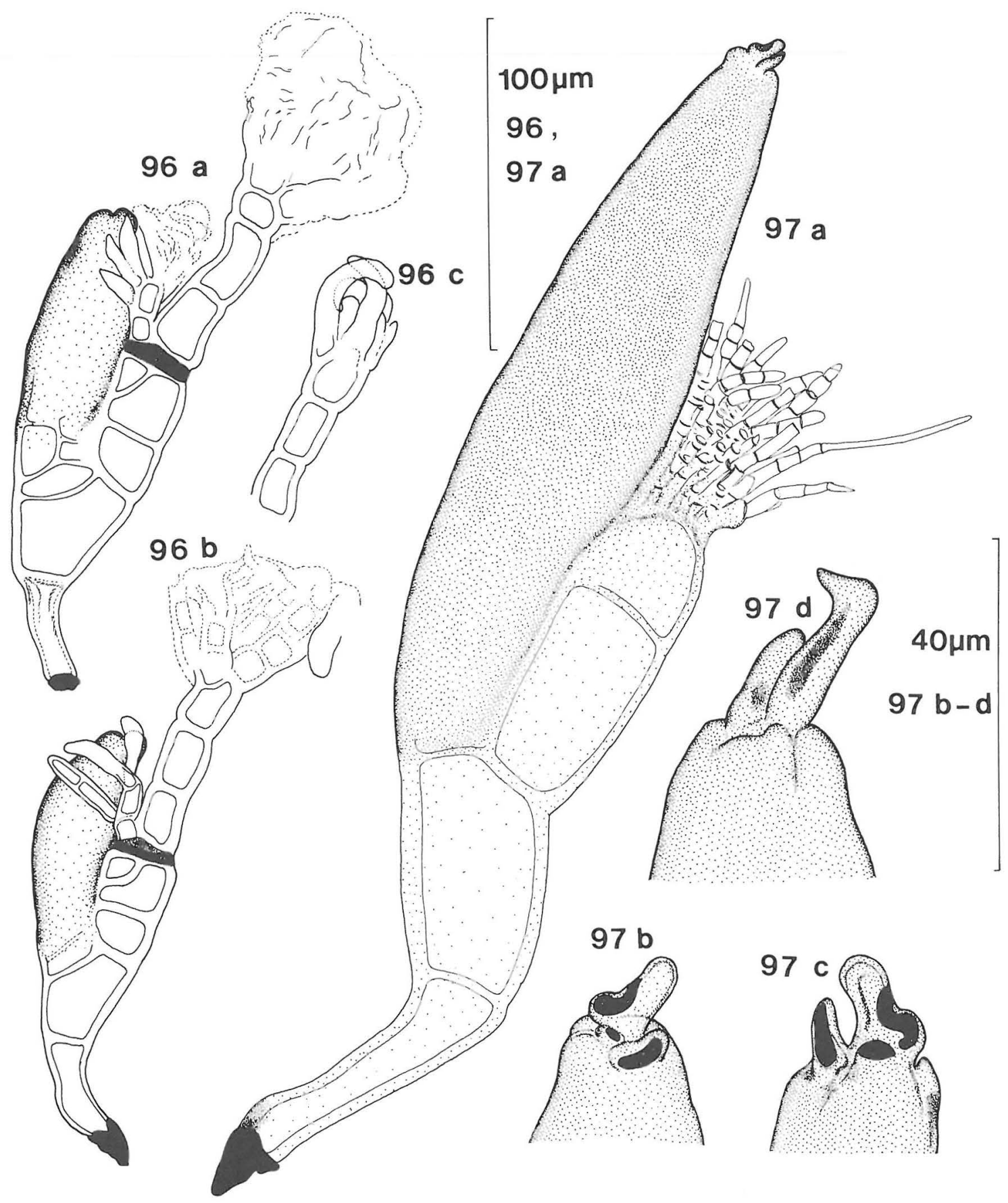

Figs. 96-97. - 96: Laboulbenia hastiana n.sp. from Bembidion hasti, a)-b) mature specimens, c) outer appendage. a) holotype. - 97: Laboulbenia fennica, n.sp. and Laboulbenia gyrinicola, a) holotype of Laboulbenia fennica, b)-c) tip of perithecium (L. fennica), d) tip of perithecium (L. gyrinicola). L. fennica from Gyrinus aeratus (Finland) and $L$. gyrinicola from Gyrinus substriatus (Czechoslovakia). - Continued on next page. 


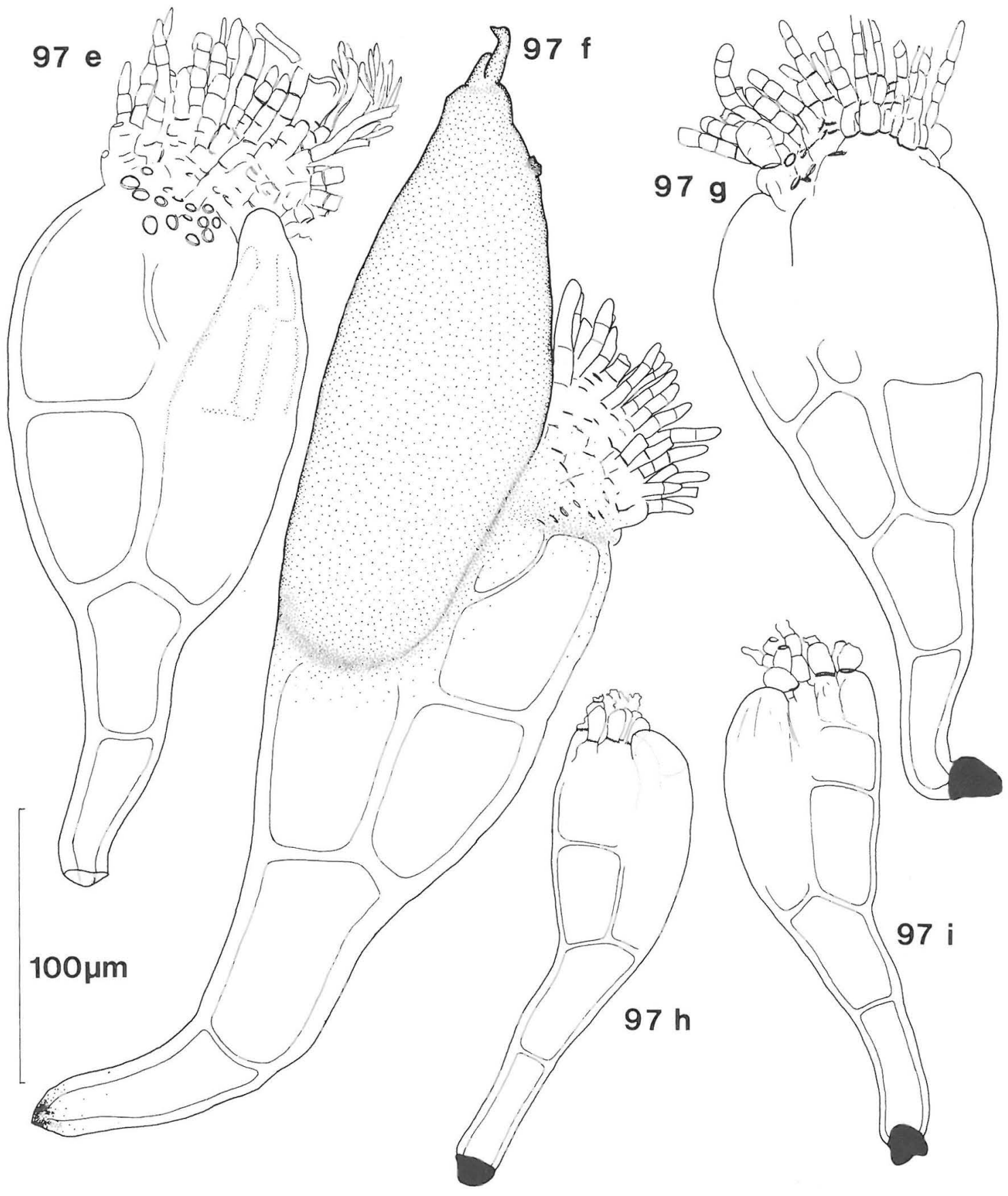

Fig. 97 (continued): e) and g) immature specimens of L. gyrinicola (Sweden), f) mature specimen of L. gyrinicola (Czechoslovakia), h)-i) immature specimens of L. fennica (Finland). L. fennica from Gyrinus aeratus and L. gyrinicola from Gyrinus substriatus. 


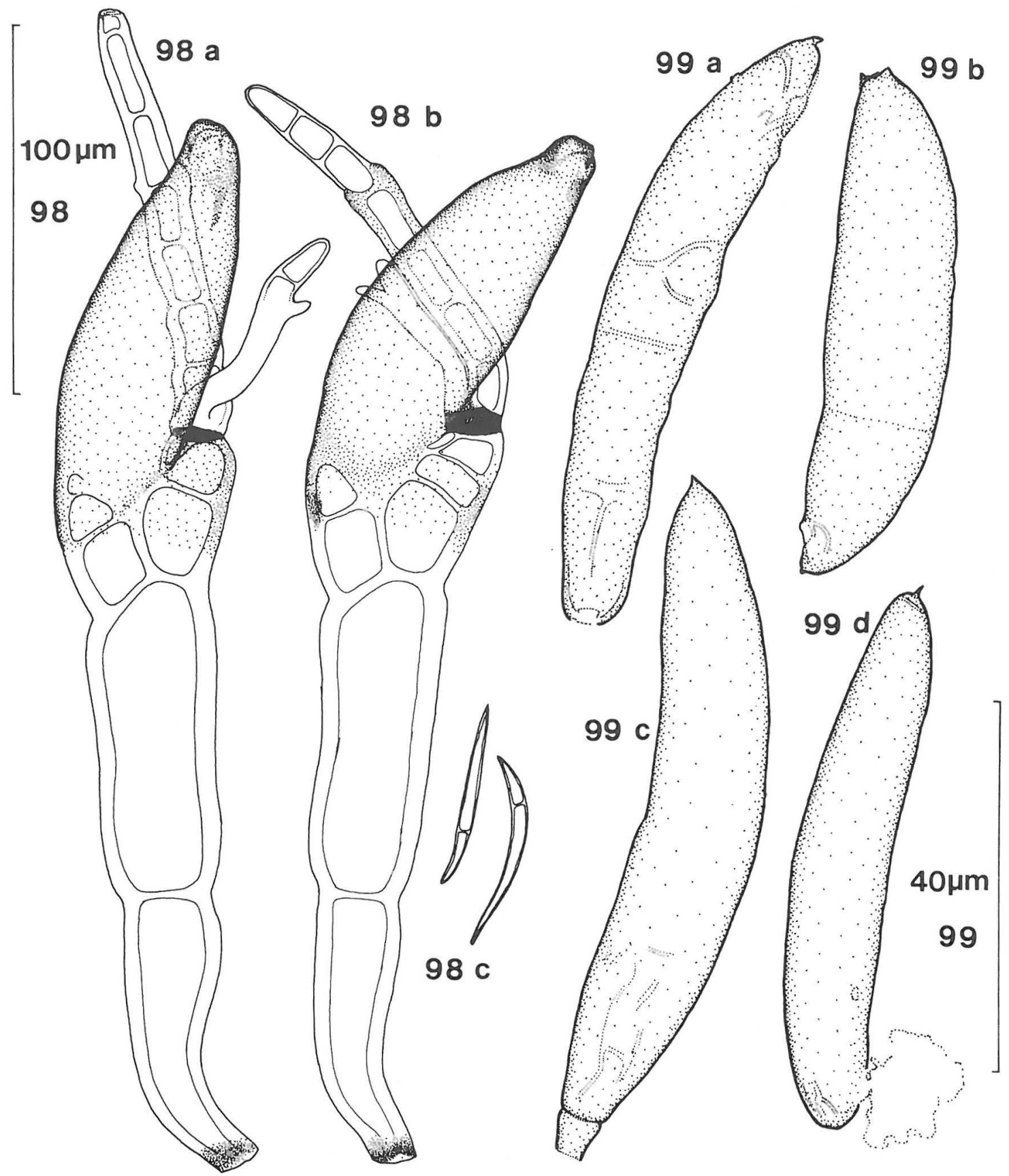

Figs. 98-99. - 98: Laboulbenia kajanensis n.sp. from Pterostichus diligens, a) holotype, b) specimen with divided cell IV, c) spores. - 99: Amphoromorpha sp. from Atheta longicornis, a)-d) variation of the thallus. 


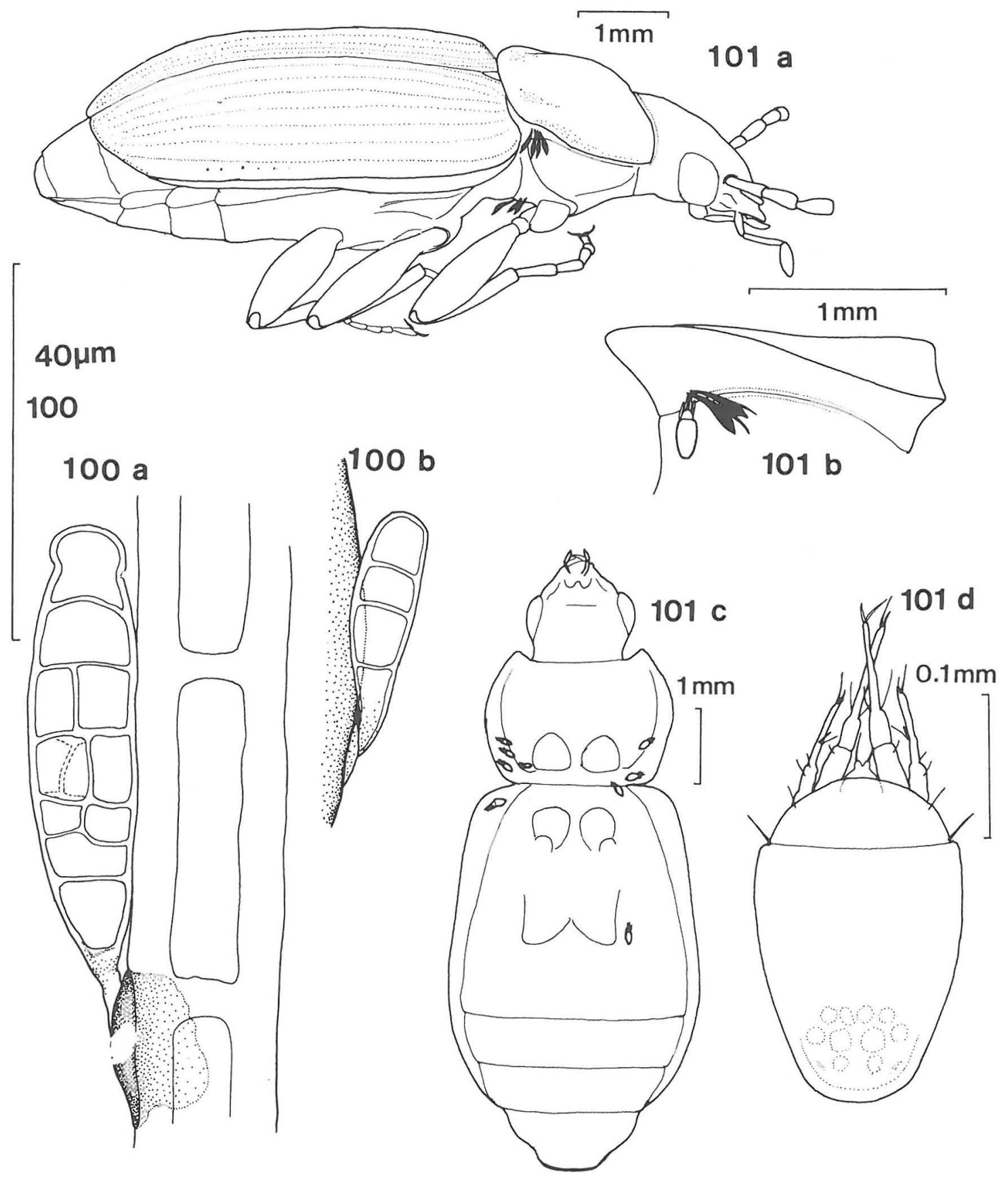

Figs. 100-101. - 100: Hyperparasitic fungus on Laboulbenia argutoris from Pterostichus diligens, a) specimen on outer appendage, b) specimen on perithecium. - 101: Laboulbenia flagellata and a parasitic mite on Agonum viduum, a) right lateral view of (fungus) infested beetle, b) right margin view of pronotum with fungi and a mite in the same position, c) ventral view of the beetle (legs removed), showing the principal positions of the parasitic mite, d) the parasitic mite enlargened. 


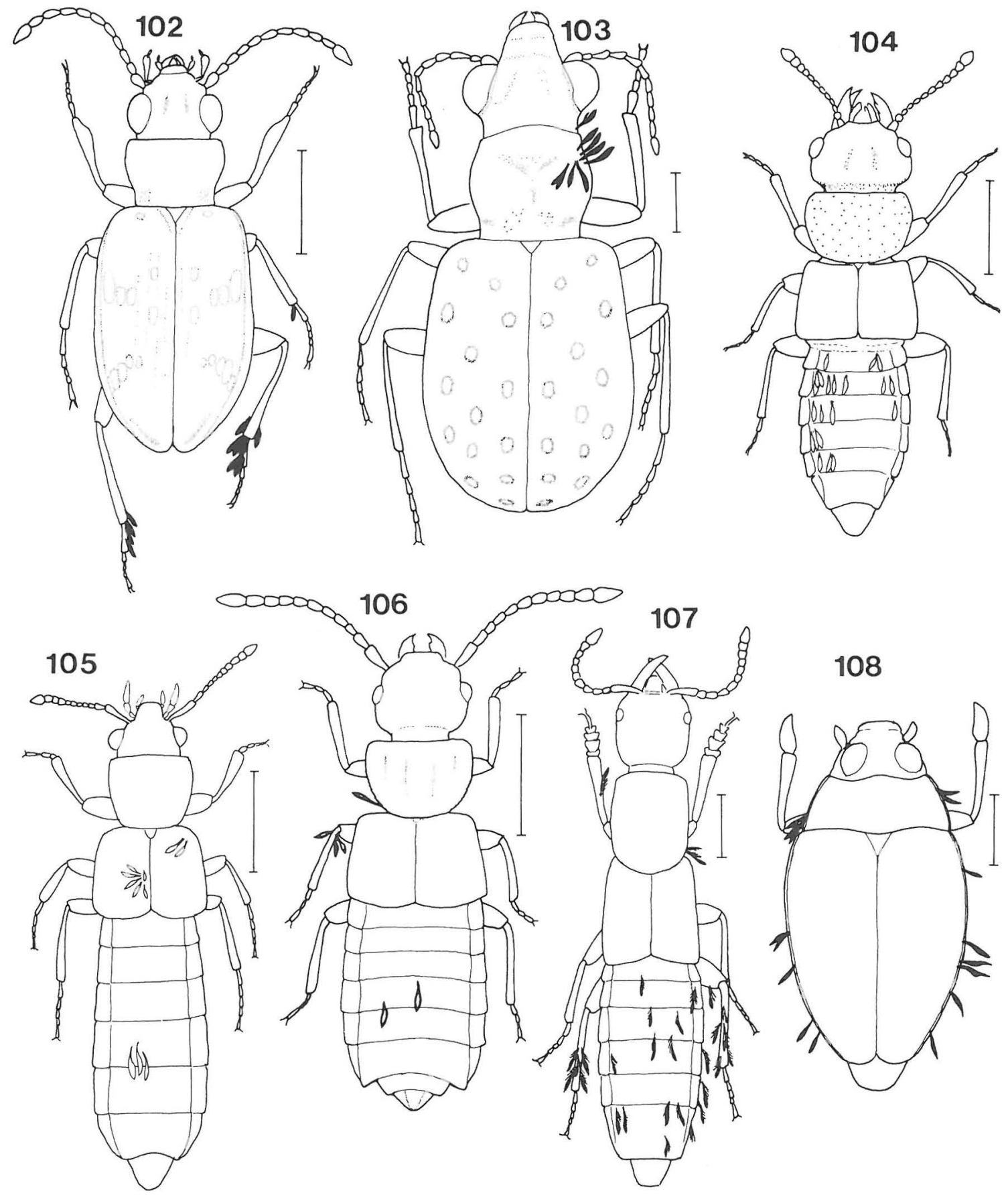

Figs. 102-108. - 102: Laboulbenia curtipes on Bembidion obliquum. - 103: Laboulbenia elaphri on Elaphrus cupreus. - 104: Monoicomyces furcatus on Oxytelus laqueatus. - 105: Haplomyces texanus on Bledius pallipes. - 106: Peyritschiella protea on Anotylus rugosus. - 107: Rhachomyces furcatus on Othius punctulatus. - 108: Laboulbenia fennica on Gyrinus aeratus. -Scale $1 \mathrm{~mm}$. 


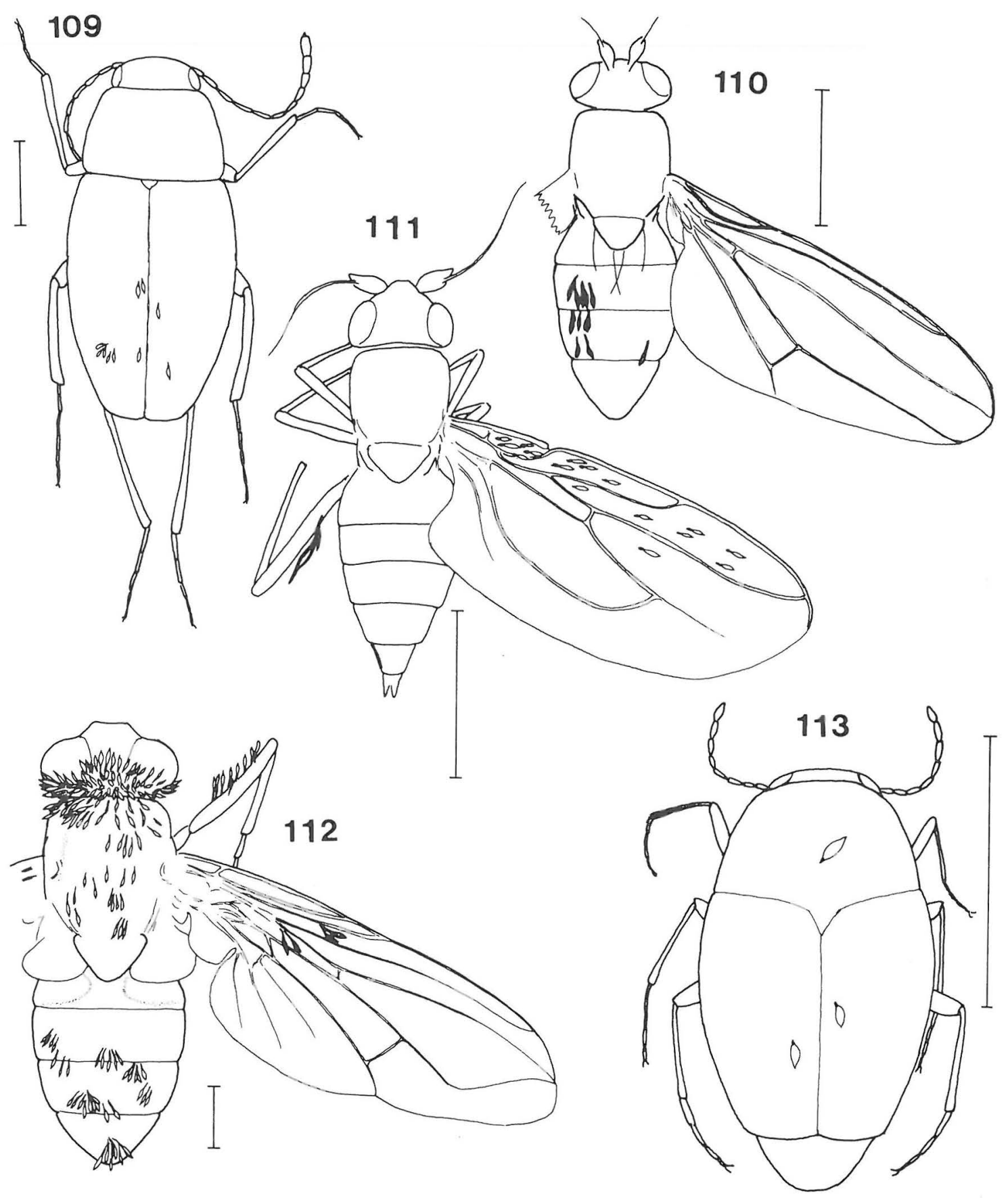

Figs. 109-113. - 109: Corethromyces henrotii on Choleva septentrionum. - 110: Stigmatomyces hydrelliae on Hydrellia griseola. - 111: Stigmatomyces hackmanii on Limosina schmitzi. - 112: Stigmatomyces baeri on Musca domestica. - 113: Rickia peyerimhoffii on Scaphisoma agaricinum. - Scale $1 \mathrm{~mm}$. 


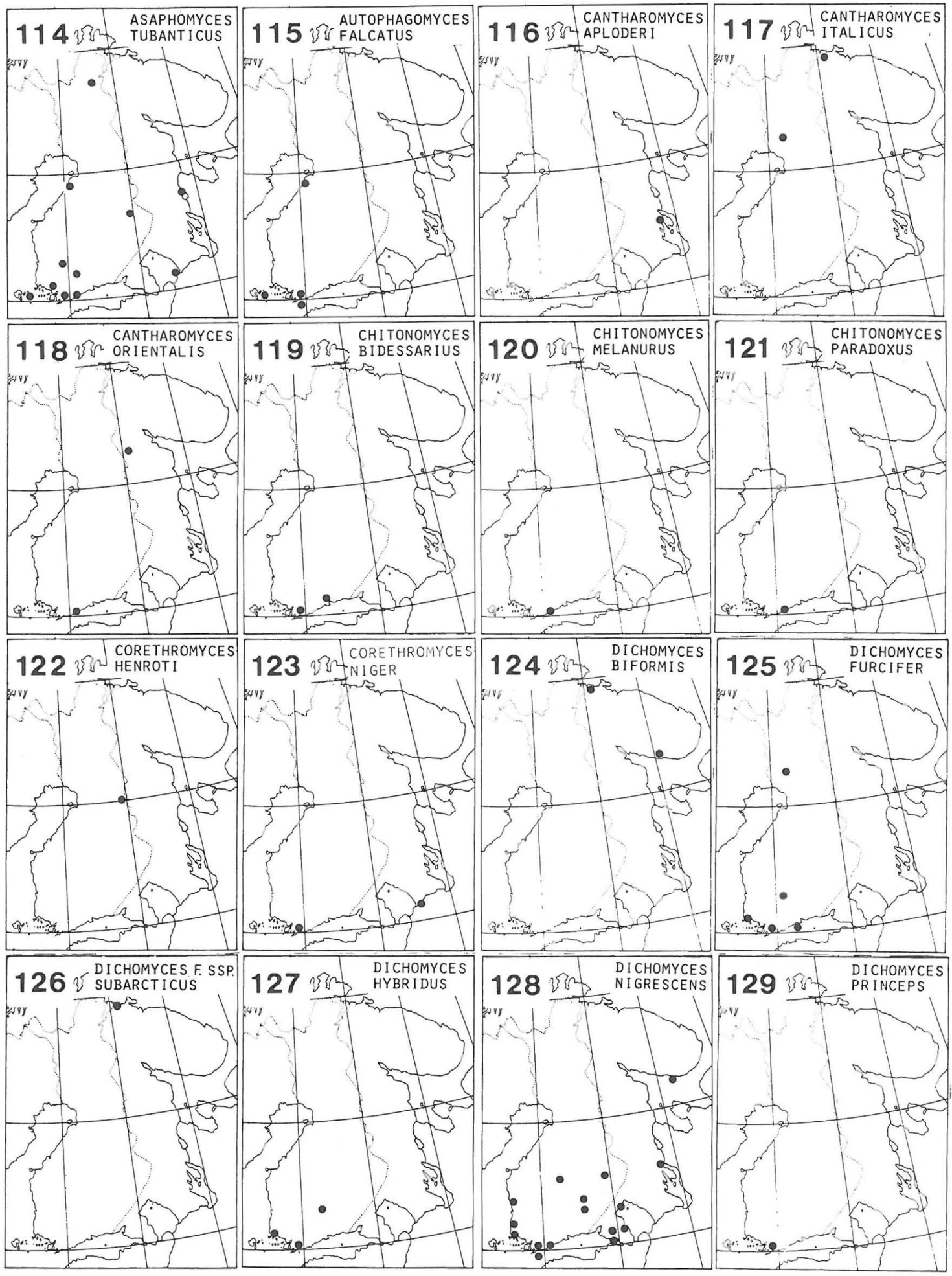

Figs. 114-204. Distribution maps. $O=$ parasite, $O=$ uninfested host specimens (the host species at lower margin). 


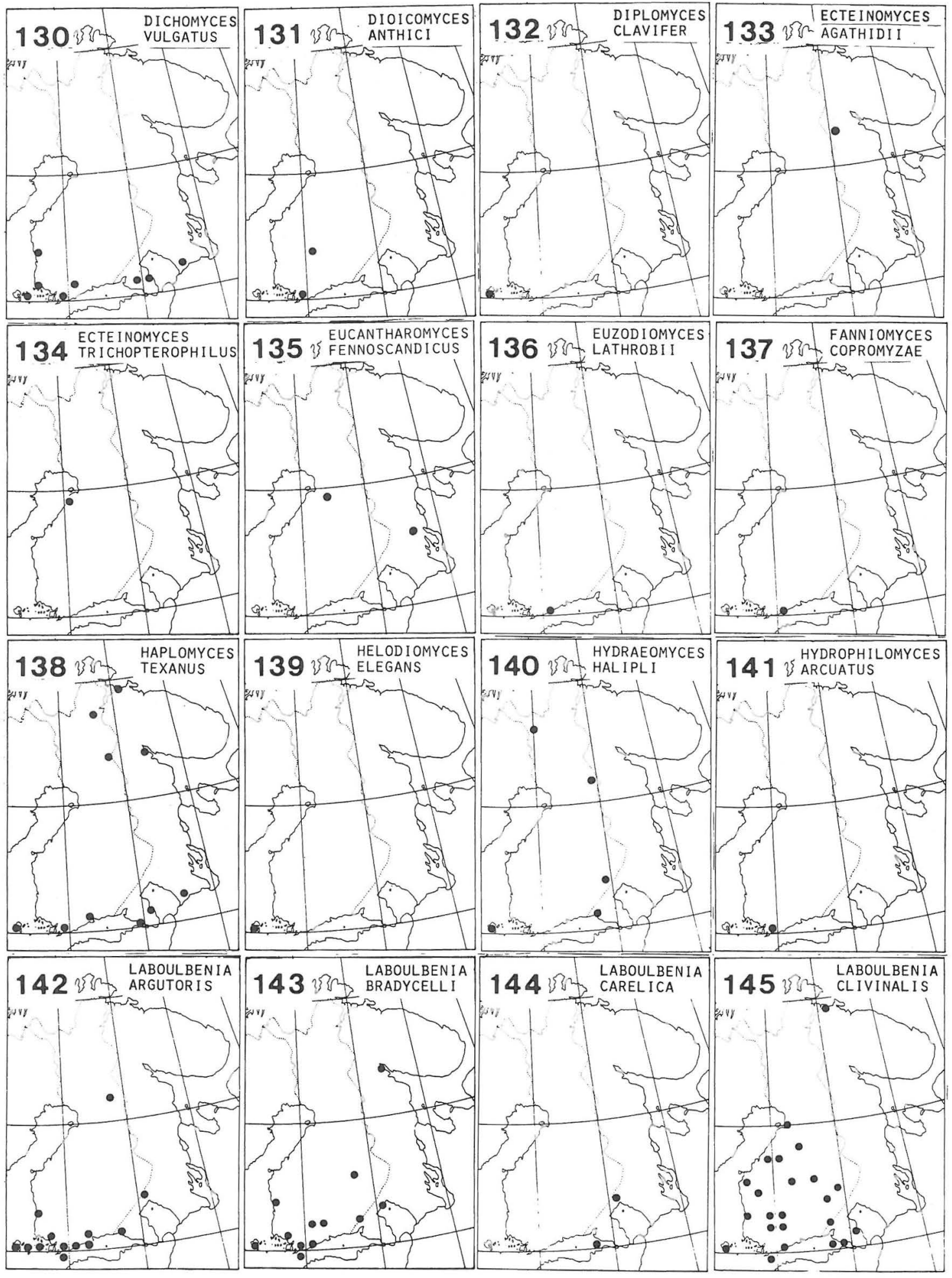




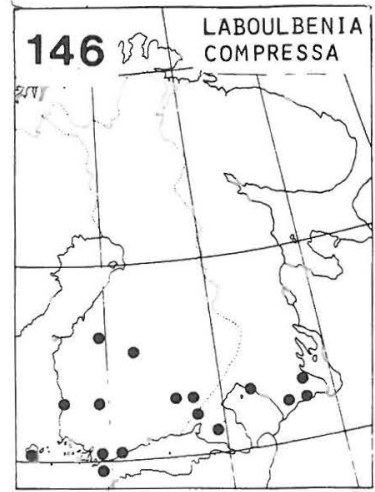

149 b

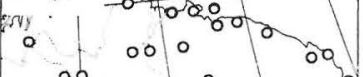

$\begin{array}{lllll}0 & 0 & 0 \\ 0 & 00 & 8 & 0 & 0 \\ 0 & 0 & 0\end{array}$
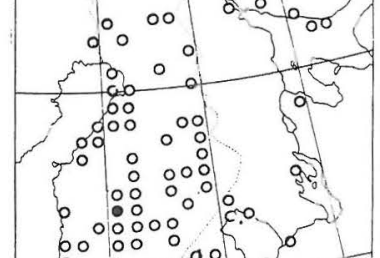

0003000 . 00 \% PATROBUS \begin{tabular}{l}
000000 .00 PATROBUS \\
\hline ASSIMILIS
\end{tabular}

$151353 \%$ FABOULBENIA
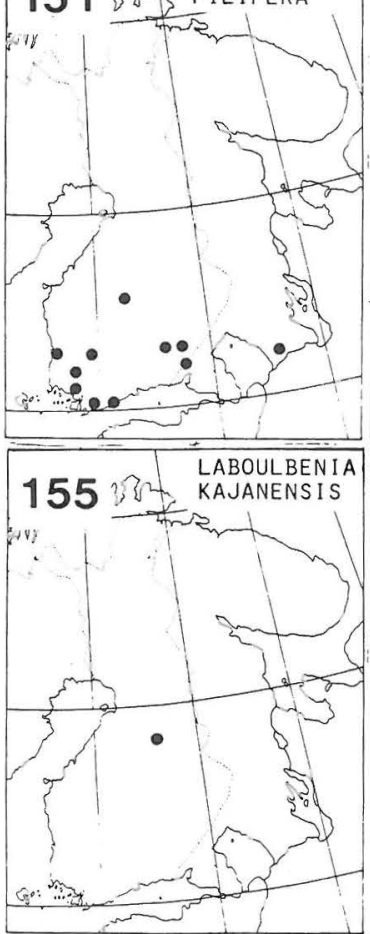
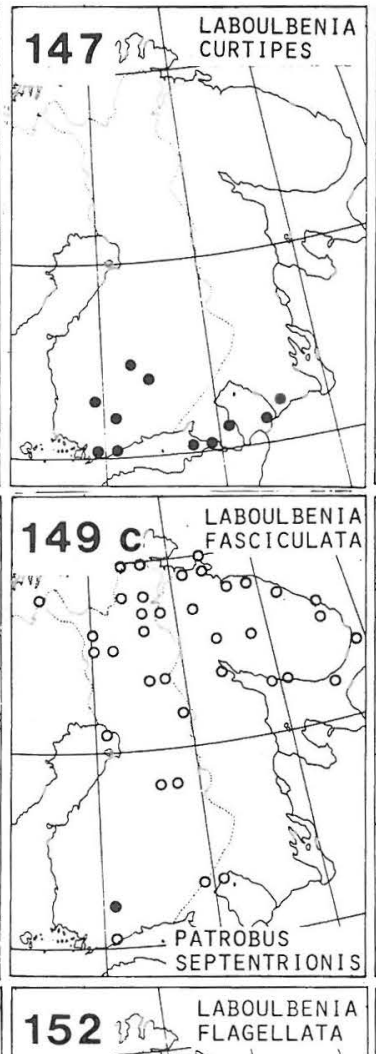
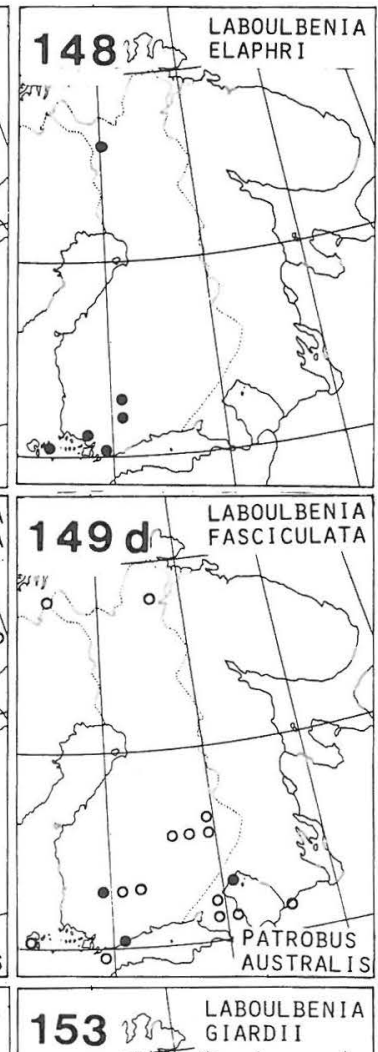
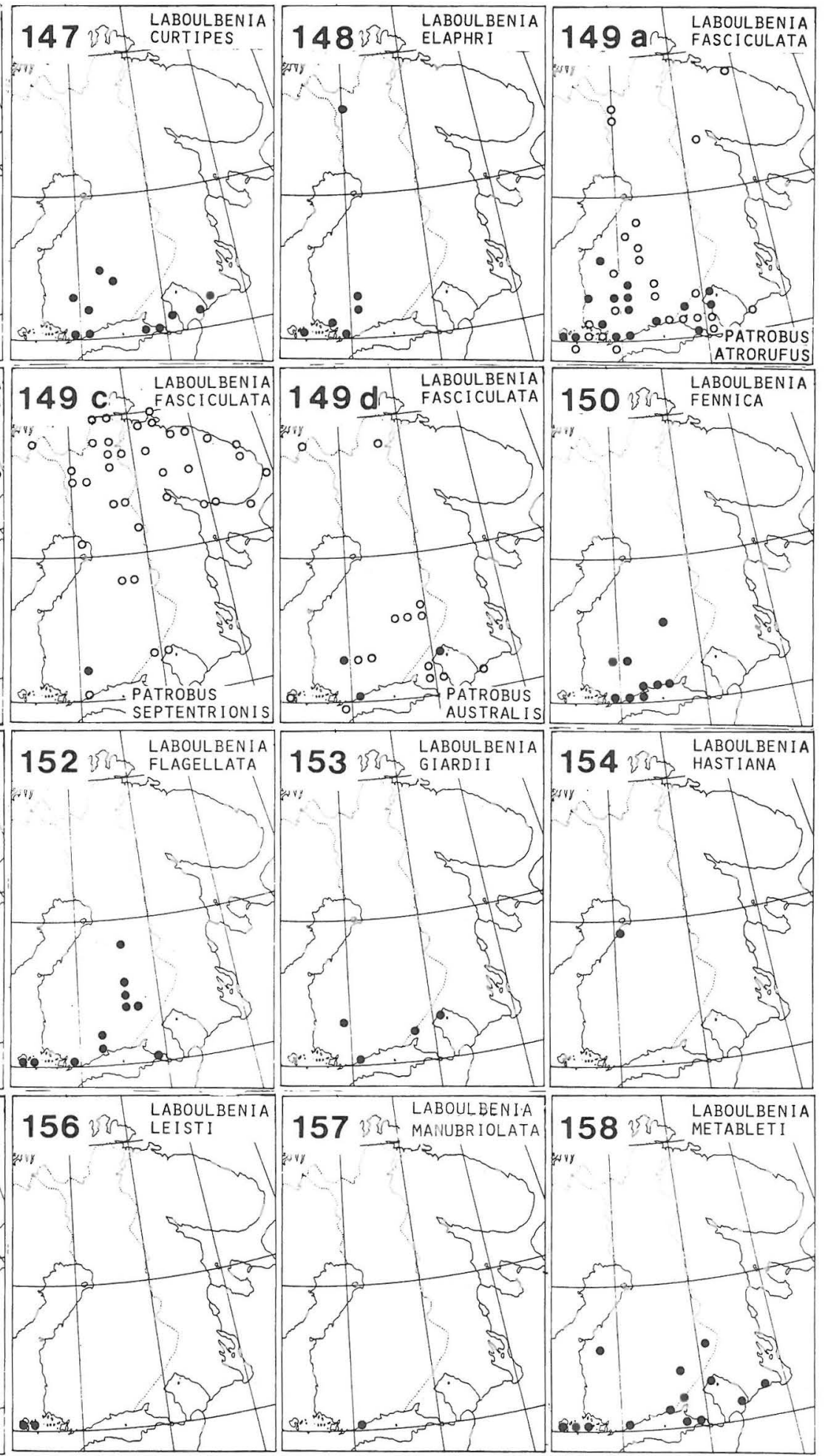


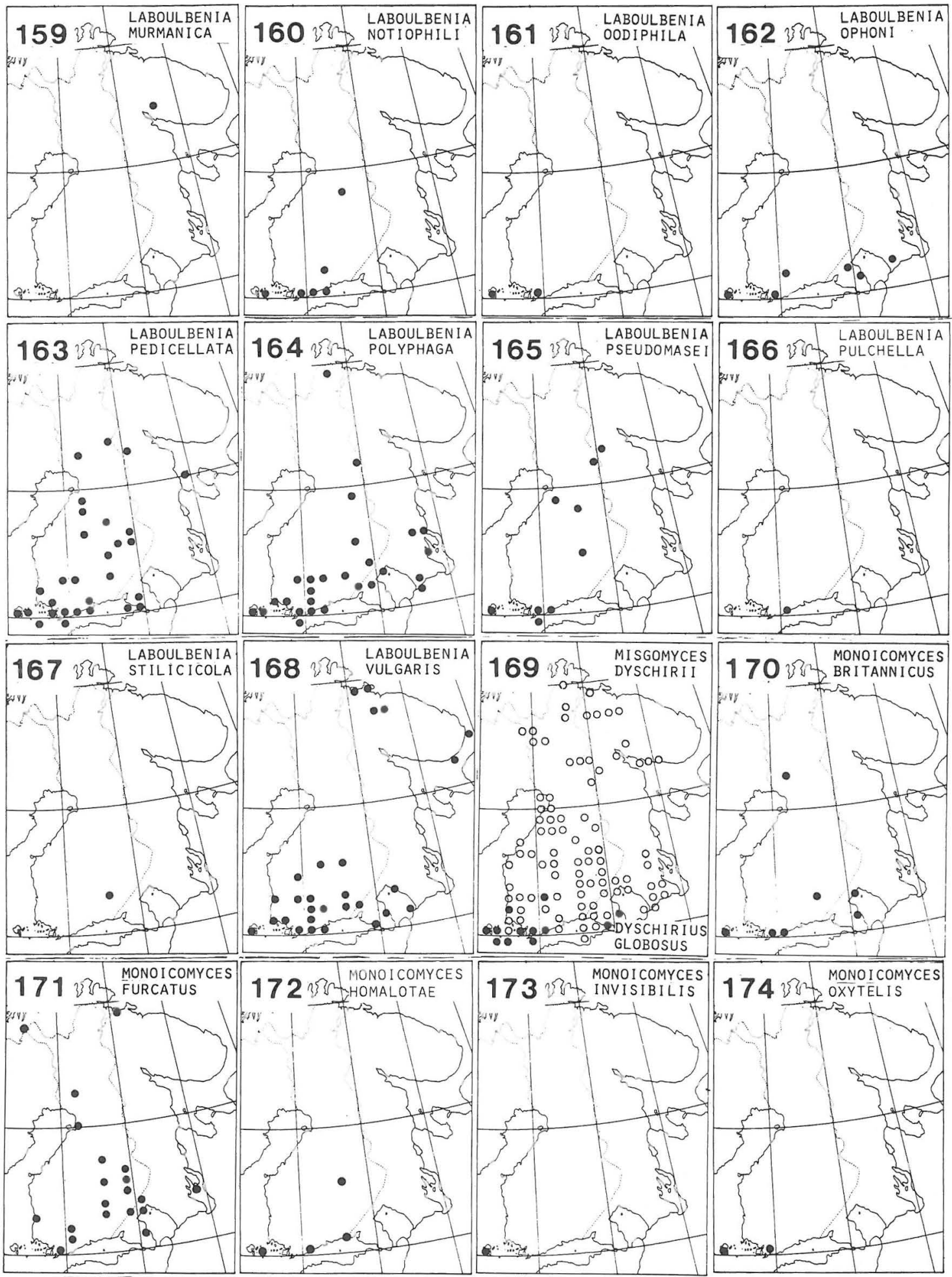




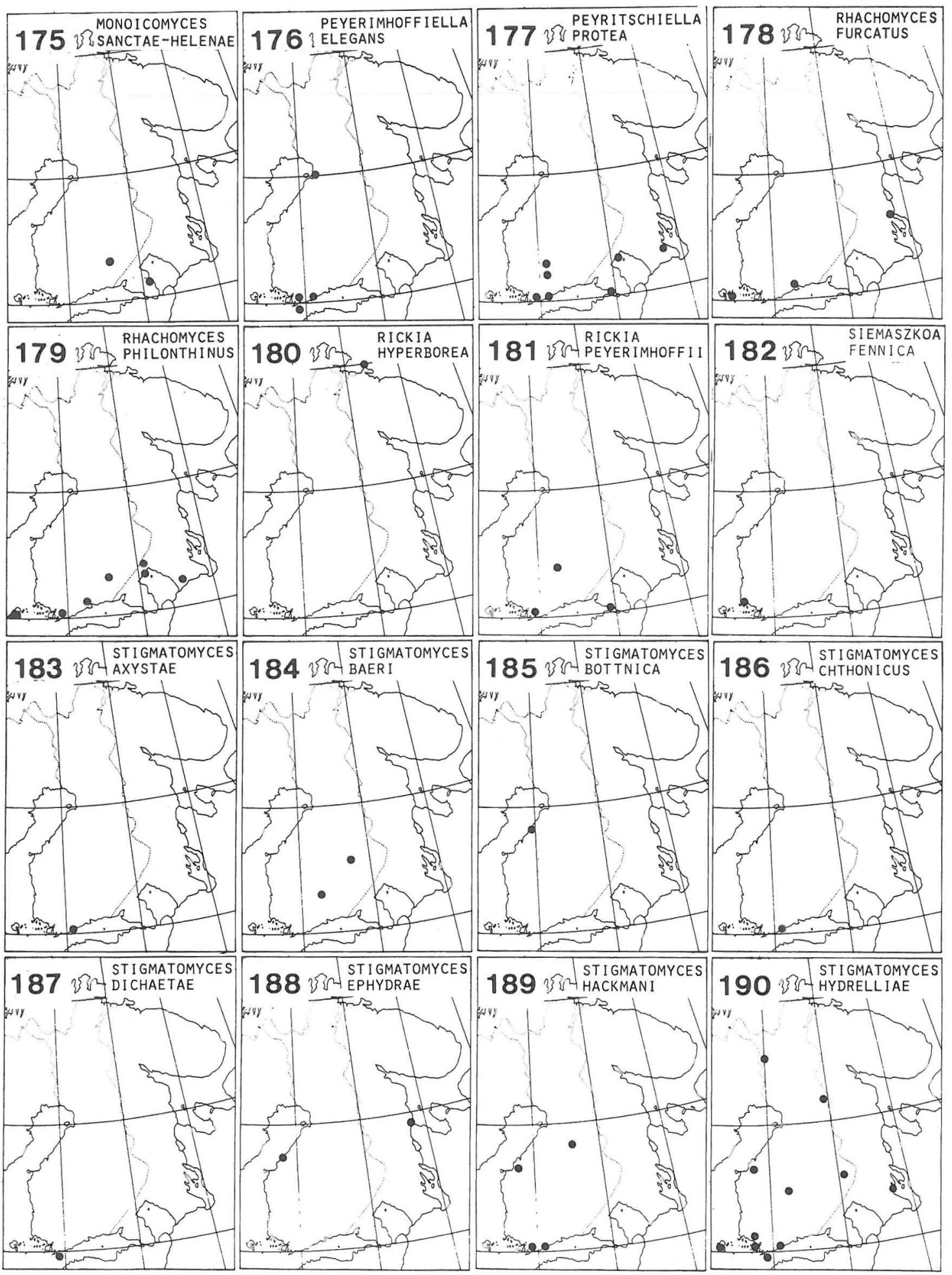




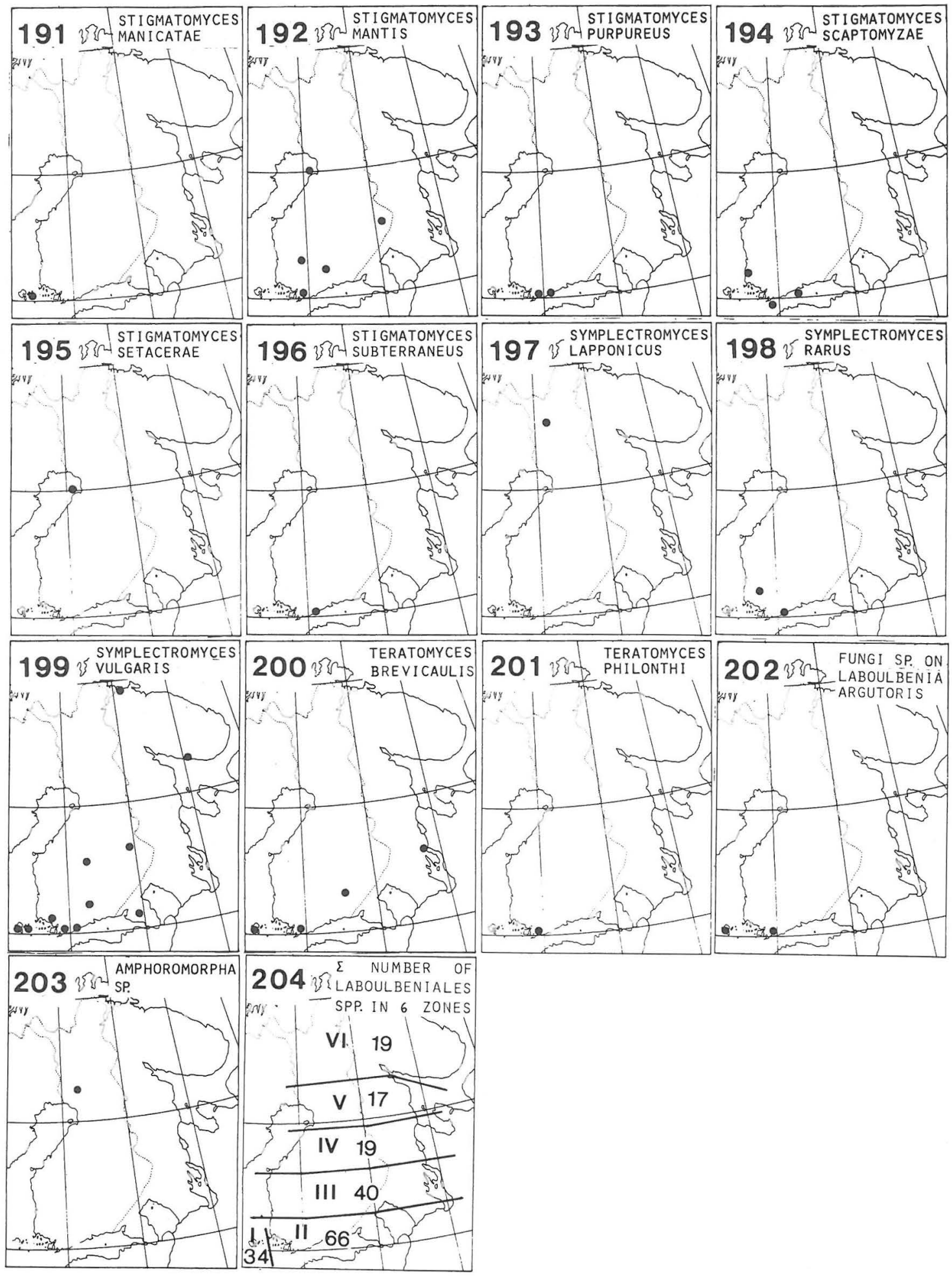




\section{References}

Albrecht, A. 1979: Utbredningen av rätvingar, kackerlackor och tvestjärtar i Östra Fennoscandien (Orthoptera, Blattodea, Dermaptera). - Notulae Entomol. 59: 53-64.

Alexopoulos, C.J. \& Mims, C.W. 1979: Introductory mycology. Third edition. - 632 pp. New York.

Arwidsson, Th. 1946: Om svenska laboulbeniacéfynd. Svensk Bot. Tidskr. 40: 307-309.

Balazuc, J. 1971a: Labulbéniales inédites, parasites de Carabiques et d'un Catopidae. - Nouv. Rev. Ent. 1: 245254.

- 1971b: Notes sur les Laboulbéniales 2. Laboulbenia parasites des Gyrinus (plus particulièrement Européens et Nord-Africains). - Bull. Mens. Soc. Linn. Lyon 40(6): $160-168$

- 1973: Ebauche d'une flore des Laboulbéniales de Roumanie (Ascomycetes). - Livre du Cinquantenaire de l'Institut de Spéléologie 'Emile Racovitza', Bucarest: 463-477.

- 1973-74: Laboulbéniales de France. - Bull. Soc. Linn. Lyon 42: 244-256, 280-285, 43: 12-21, 57-64, 73$79,253-262,295-315,346-368$.

- 1978: Labulbéniales (Ascomycetes) de la region Francaise Antilles-Guyane. - Bull. Soc. Linn. Lyon 47: 488500.

- 1980: Laboulbéniales nouvelles (Ascomycetes), parasites de Coléoptères et de Diptères. - Bull. Mus. Nat. Hist. Nat. $4^{\mathrm{e}}$ ser. (section B) 2(2): 209-219.

- 1982: Laboulbéniales (Ascomycetes) de Madagascar, des Comores et des Mascareignes. - Bull. Soc. Linn. Lyon 51(1): 6-27.

Balazuc, J., Espadaler, J., Girbal. J. 1982: Laboulbenials (Ascomicets) Ibèriques. - Collnea Bot. Barcinone 13(2): 403-421.

Balazy, S. \& Wiśniewski, J. 1974: Aegeritella superficialis gen. et sp. nov. - epifityczny grzyb na mrówkach $\mathrm{z}$ rodzaju Formica L. - Prace Kom. Nauk Roln. \& Kom. Nauk Leśn 38: 3-15.

Banhegyi, J. 1940: Elömunkálatok a magyarországi Laboulbenia-félék monografiájához. (Etudes préliminaires sur les Laboulbéniales de la Hongrie.) - Index Horti Bot. Univ. Budapest 4: 39-59.

- 1944: A Balaton környékének Laboulbenia-féléi. (Les Laboulbéniales aux environs du lac de Balaton.) - Bot. Kozlemények 41: 49-61.

- 1949: Les Laboulbéniales de la Transylvanie. - Index Horti Bot. Univ. Budapest 7: 93-101.

- 1950: Ritka Laboulbeniák a Kárpátmedencéböl. - Ann. Biol. Univ. Budapest. 1: 189-196.

- 1960: Contributions á la connaissance des Laboulbéniales de la péninsule des Balkans. - Ann. Univ. Sci. Budapest. Sect. Biol. 3: 49-67.

- 1964: Notes sur quelques Laboulbéniales de la Pologne. - Ann. Univ. Sci. Budapest. Rolando Eötvös nomin., Sect. Biol. 7: 19-27.

Batra, S.W.T. 1963: Some Laboulbeniaceae (Ascomycetes) on insects from India and Indonesia. - Amer. J. Bot. 50: $986-992$.

Baumgartner, R. 1923: Contribution à l'étude des Laboulbéniales de la Suisse. - Jahrb. Philosoph. Fakultät II Univ. Bern 3: $257-265$.

- 1934: Quelques questions relatives aux Laboulbéniales (Champignons sur insectes vivants). - Mitt. Naturforsch. Ges. Bern 1933: xxxxv-xxxxvii.

- 1951: Résultats de mes dernières recherches sur les Laboulbéniales (Champignons sur insectes vivants). Mitt. Naturforsch. Ges. Bern. Neue Folge 8: xxx-xxxiii.

von Beck, G.R. 1903: Über das Vorkommen des auf der Stubenfliege lebenden Stigmatomyces Baeri Peyr. in Böhmen. - Sitz.Ber. deut. naturwissensch.-medizinisch. Ver. für Böhmen, 'Lotos', Prague 23: 101-102.

Benjamin, R.K. 1955: New genera of Laboulbeniales. - El Aliso 3: 183-197.

- 1965: Study in specificity. - Nat. Hist. 74: 42-49.

- 1967: Laboulbeniales on semi-aquatic Hemiptera. Laboulbenia. - Aliso 6(3): 111-136.
- 1968a: Sandersoniomyces, a new genus of Laboulbeniales allied to Diplomyces, Symplectromyces and Teratomyces. - Aliso 6(4): 1-16.

- 1968b: Balazucia, a new genus of Laboulbeniales allied to Cucujomyces Spegazzini. - Aliso 6(4): 47-56.

- 1971: Introduction and supplement to Roland Thaxter's contribution towards a monograph of the Laboulbeniaceae. - Bibliotheca Mycol. 30:1-155.

- 1973: Laboulbeniomycetes. - In: Ainsworth, G.C. Sparrow, F.K. \& Sussman, A.S. (eds.), The fungi, an advanced treatise, 4 A: 223-246. New York \& London.

Benjamin, R.K. \& Shanor, L. 1951: Morphology of immature stages of Euzodiomyces lathrobii and the taxonomic position of the genus Euzodiomyces. - Amer. J. Bot. 38: $555-560$.

- 1952: Sex of host specificity and position specificity of certain species of Laboulbenia om Bembidion picipes. - Amer. J. Bot 39: 125-131.

Biffen, R.H. 1909: First record of two species of Laboulbeniaceae from Britain. - Trans. Brit. Mycol. Soc. 3: 83.

Bisby, G.R. \& Mason, E.W. 1940: List of Pyrenomycetes recorded from Britain. - Trans. Brit. Mycol. Soc. 24: $127-243$.

Blackwell, M. \& Kimbrough, J.W. 1978: Hormiscioideus filamentosus gen. et sp. nov., a termite-infesting fungus from Brazil. - Mycologia 70: 1274-1280.

Blum, G. 1924: Zwei neue Laboulbenien aus Brasilien. Centr. Bl. Bakteriol., Parasitenkr. und Infektionskrankh., 2-Abt. 62: 300-302.

Boedijn, K. 1923: On the development of Stigmatomyces. -Meded. Nederl. Mycol. Vereen. 13: 91-97.

Boyer-Lefevre, N.H. 1966: Les Laboulbéniales des Trechinae cavernicoles pyrenéens. - Ann. Spéléologie 21: $775-794$.

Briedis, A. 1932: Laboulbeniaceae in Latvia, - Acta Horti Bot. Univ. Latviensis 7: 131-134.

Bro Larsen, E. 1952: On subsocial beetles from the saltmarsh, their care of progeny and adaption to salt and tide. - Trans. IX Int. Congr. Ent. Amsterdam 1951, 1: 502-506.

Buchli, H.R. 1966: Notes sur les parasites fongiques des Isoptéres. - Rev. Ecol. Biol. Sol. Fr. 3(4): 589-610.

Cavaliere, A.R. \& Johnson T.W. 1965: A new Ascomycete from Australia. - Mycologia 57: 927-932.

Cépède, C. 1913: Etude des Laboulbéniacées Européennes: Laboulbenia blanchardi n.sp. et son parasite Fusarium Laboulbeniae n.sp. - Arch. Parasit. 16: 373-403.

Cépède, C. \& Picard, F. 1908: Observations biologiques sur les Laboulbéniacées et diagnoses sommaires de quelques espéces nouvelles. Comptes rendus Assoc. Franç. Avancement Sci.; $36{ }^{{ }^{e}}$ sess., Reims 1907: 778-784.

- 1909: Contribution à la biologie et à la systématique des Laboulbéniacées de la flore française. - Bull. Sci. Fr. Belg. 42: 247-268.

Clausen, P.J. 1977: A revision of the nearctic, neotropical and palearctic species of the genus Ochthera, including one Ethiopian species and one new species from India. - Trans. Amer. Ent. Soc. 103: 451-530.

Colla, S. 1925: Contributo alla conoscenza dei Laboulbeniali piemontesi. - Atti Reale Accad. Sci. Torino 60: $250-269$.

- 1934: Laboulbeniales. - Flora italica cryptogamica, pars 1, Fungi 16: $1-157$.

Collart, A. 1945: A propos des Laboulbéniacées. - Les Naturalistes Belges 26: 98-103.

Collingwood, C.A. 1979: The Formicidae (Hymenoptera) of Fennoscandia and Denmark. - Fauna Ent. Scand. 8: $1-174$.

Dahl, R.G. 1959: Studies of Scandinavian Ephydridae (Diptera Brachycera). - Opusc. Ent. Suppl. 15: 1-224.

Dainat, H. 1971: Stigmatomyces hydrelliae Thaxter (Laboulbeniales). Espece nouvelle pour la France et l'Europe. -Nouv. Rev. Ent. 1: 149-154.

Dainat, H. \& Dainat, J. 1973: Sur dix especes du genre Stigmatomyces (Laboulbeniales) parasites de Dipteres Acalypteres dans le sud de la France. - Bull. Soc. Mycol. Fr. 89: $337-352$. 
Eriksson, O. 1982: Outline of the Ascomycetes - 1982. Mycotaxon 15: 203-248.

Eriksson, U. 1972: The invertebrate fauna of the Kilpisjärvi area, Finnish Lapland 11. Haliplidae, Gyrinidae and Hydrophilidae. - Acta Soc. Fauna Flora Fennica 80: $161-164$.

Frank, J.H. 1982: The parasites of the Staphylinidae (Coleoptera). - Techn. Bull. Agric. Exp. St. Inst. Food Agric. Sci. Univ. Fla. 824: 1-118.

Green, J. 1954: The food, predators and a parasite of Bembidion laterale (Samouelle) (Col., Carabidae). - Entomol. Monthly Mag., 90: 226-227.

Hackman, W. 1963: Studies on the Dipterous fauna in burrows of voles (Microtus, Clethrionomys) in Finland. Acta Zool. Fenn. 102: 1-64.

- 1980: A check list of the Finnish Diptera 2. Cyclorrhapha. - Notulae Entomol. 60: 117-162.

Hincks, W.D. 1960: Notes on the Laboulbeniales. - The Naturalist 1960: 97-102.

Huggert, L. 1973: Laboulbeniales on Coleoptera from Sweden (Ascomycetes) 1. Host Families Silphidae and Liodidae. - Svensk Bot. Tidskr. 67: 238-252.

Huldén, L. 1983: Distribution of Gyrinidae (Coleoptera) in Eastern Fennoscandia. - Notulae Entomol. 63: 81-85.

Kamburov, S.S., Nadel, D.J. \& Kenneth, R. 1967: Observations on Hesperomyces virescens Thaxter (Laboulbeniales), a fungus associated with premature mortality of Chilocorus bipustulatus L. in Israel. - Israel J. Agr. Res. 17: 131-134.

Karsten, H. 1869: Chemismus der Pflanzenzelle. - 90 pp. Wien.

Khan, S.R. \& Kimbrough, J.W. 1974: Taxonomic position of Termitaria and Mattirolella (entomogenous Deuteromycetes). - Amer. J. Bot. 51: 2307-2314

Kimbrough, J.W. \& Lenz, M. 1982: New species of Termitaria (Termitariales, Deuteromycetes) on Australian termites (Isoptera). - Bot. Gaz. 143: 262-272.

Kloet, G.S. \& Hincks, W.D. 1964: A check list of British insects 1: Small orders and Hemiptera. Second edition. - Handb. Identific. Brit. Insects 11(1): 1-119.

Knoch, J. 1868: Laboulbenia baeri Knoch ein neuer Pilz auf Fliegen. - Ass. Nat. Russie, St-Petersburg, déc. 1867 -janv. 1868: 908.

Kohlmeyer, J. 1973: Spathulosporales, a new order and possible missing link between Laboulbeniales and Pyrenomycetes. - Mycologia 65: 614-647.

- 1975: New clues to the possible origin of Ascomycetes. -BioScience 25(2): 86-93.

Koval, E.Z. 1974: Opredelitel' entomofilnyh gribov SSSR. -260 pp. Kiev.

Krantz, G.W. 1978: A manual of acarology. Second edition. -509 pp. Corvallis.

Larsson, S.G. 1978: Baltic amber - a palaeobiological study. - Entomonograph 1. 192 pp. Klampenborg.

Lindberg. H. 1937: Ökologische studien über die Coleopteren und Hemipterenfauna im Meere in der Pojo-Wiek und im Schärenarchipel von Ekenäs in Südfinnland. Acta Soc. Fauna Flora Fennica 60: 516-572.

Lindroth, C.H. 1945: Die Fennoskandischen Carabidae 1. -Göteborgs Kungl. Vet. Vitt. Samh. Handl. (Ser. B) 4(1): $1-709$ :

- 1948: Notes on the ecology of Laboulbeniaceae infesting carabid beetles. - Svensk. Bot. Tidskr. 42: 34-41.

- 1963: The ground-beetles (Carabidae, excl. Cicindelinae) of Canada and Alaska 3. - Opusc. Entomol., Suppl. 29: $201-408$.

Madelin, M.F. 1968: Fungal parasites of invertebrates 1. Entomogeneous Fungi. - In: Ainsworth, G.C. \& Sussman, A.S. (eds.), The fungi, an advanced treatise 3: 227-238. New York \& London.

Mainardi, A. 1915: Sui lavori di Laboulbeniologia de Pr. C. Spegazzini: invito ai Colleotterologi italiani; Catalogo di Artropodi italiani sinora riscontrati afetti da Laboulbeniomiceti. - Rev. Coleotterologica Ital. 12: 88-103.

Maire, R. 1916a: Deuxiéme contribution à l'étude des Laboulbéniales de l'Afrique du Nord. - Bull. Soc. d'Hist. Nat. Afr. Nord 7: 6-39.
- 1916b: Sur une nouvelle Laboulbéniale parasite des Scaphidiidae. - Bull. Sci. Fr. Belg. 49: 290-296.

- 1920: Troisième contribution à l'étude des Laboulbéniales de l'Afrique du Nord. - Bull. Soc. d'Hist. Nat. Afr. Nord 41: $123-138,143-158,159-170$.

Majewski, T. 1971: Rare and new Laboulbeniales from Poland. - Acta Mycol. 7: 269-277.

- 1972: Rare and new Laboulbeniales from Poland 2. Acta Mycol. 8: 229-237.

- 1973a: Rare and new Laboulbeniales from Poland 3. Acta Mycol. 9: 111-124.

- 1973b: Rare and new Laboulbeniales from Poland. 4. -Acta Mycol. 9: 229-238.

- 1980: Rare and new Laboulbeniales from Poland. 6. Acta Mycol. 16: 141-153.

- 1981: Rare and new Laboulbeniales from Poland. 7. Acta Mycol. 17: 53-62.

Majewski, T. \& Wiśniewski, J. 1978: New species of parasitic fungi occurring on mites (Acarina). - Acta Mycol. 14: $3-12$.

Mercier, L. \& Poisson, R. 1927: Une Laboulbéniale, Stigmatomyces ephydrae n.sp., parasite d'Ephydra riparia Fall. (Dipt. Ephydridae). - Bull. Soc. Zool. Fr. 52: 225231.

Middelhoek, A. 1941: Dichomyces princeps Thaxter. Fungus $12(5-6)$ : $56-57$.

- 1943a: Laboulbeniaceae in Nederland. - Nederl. Kruidk. Arch. 53: 86-115.

- 1943b: Enige nieuwe Laboulbeniales voor ons land. Fungus 14: $57-59$

- 1943c: Enige nieuwe Laboulbeniales voor ons land. Fungus 14: $71-72$

- 1947: Laboulbeniaceae in Nederland 2. - Nederl. Kruidk. Arch. 54. 232-239.

- 1949: Laboulbeniaceae in Nederland 3. - Nederl. Kruidk. Arch. 56: 249-260.

Palm, T. 1932: Om coleopterfaunan i Ormbergstrakten. Tilllägg. - Entomol. Tidskr. 53: 210-224.

Peyritsch, J. 1873: Beiträge zur Kenntnis der Laboulbenien. - Sitz. Ber. Kaiserl. Akad. Wiss. Math.-Naturwiss. Klasse 68 (1): $227-254$.

Picard, F. 1910: Sur une Laboulbéniacée nouvelle (Hydrophilomyces digitatus n.sp.) parasite d'Ochthebius marinus Paykull. - Bull. Soc. Mycol. Fr. 25: 245-249.

- 1913: Contribution à l'étude des Laboulbéniacées d'Europe et du nord de l'Arfique. - Bull. Soc. Mycol. Fr. 29: 503-571.

- 1917: Sur quelques Laboulbéniales d'Europe. - Bull. Sci. Fr. Belg. 50: 440-460.

Poelt, J. 1952a: Laboulbenien und ihr Vorkommen in Südbayern. - Nachr. Bl. Bayer. Entomol. 1: 33-36.

- 1952b: Laboulbeniales aus Südbayern. - Mitt. Bot. Staatssam. München 4: 115-118.

Poinar, G.O. \& Thomas, G.M. 1982: An entomophtoralean fungus from Dominican amber. - Mycologia 74: 332334.

Richards, A.g. \& Smith, M.N. 1954: Infection of cockroaches with Herpomyces (Laboulbeniales) 3. Experimental studies on host specificity. - Bot. Gaz. 116: 195-198.

- 1956: Infection of cockroaches with Herpomyces (Laboulbeniales) 2. Histology and histopathology. - Ann. Entomol. Soc. Amer. 49: 85-93.

Robin, C. 1853: Histoire naturelle des végétaux parasites qui croissent sur l'homme et sur les animaux vivants. -704 pp. Paris.

Rossi, W. 1975: Su alcune Laboulbeniali (Ascomycetes) nuove per l'Italia. - Giorn. Bot. Ital. 109: 71-85.

- 1978: Sulle Laboulbeniali (Ascomycetes) parassite dei Trechini di Turchia (Coleoptera, Carabidae). - Quaderni Speleologia, Circolo Speleologico Romano 3: 18 .

- 1982a: Aphanandromyces, a new genus of Laboulbeniales (Ascomycetes). - Mycologia 74: 520-523.

- 1982b: New or interesting Laboulbeniales from China. -Mycologia 74: 1023-1026.

Rossi, W. \& Balazuc, J. 1977: Laboulbeniales parasites de Myriapodes. - Rev. Mycol. 41: 525-535. 
Rossi, W. \& Cesari, G. 1976: Contributo alla conoscenza delle Laboulbeniale (Ascomycetes) parassite di Carabidi italiani (Insecta, Coleoptera). - Giorn. Bot. Ital. 110: $145-153$.

Rossi, W. \& Cesari Rossi, G. 1977: Sulle Laboulbeniali (Ascomycetes) parassite dei Trechinae del Messico (Coleoptera, Carabidae). - Accademia nazionale dei Lincei Quaderni Acc. Naz. Lincei 171: 373-376.

- 1978: Contributo alla conoscenza delle Laboulbeniali (Ascomycetes) parassite di Stafilinidi italiani (Insecta, Coleoptera). - Giorn. Bot. Ital. 112: 63-74.

- 1979a: Su alcune specie di Stigmatomyces (Ascomycetes, Laboulbeniales) parassite di Ditteri italiani. - Boll. Mus. Civ. Venezia 30: 13-18.

- 1979b: Due specie nouve di Laboulbenia (Ascomycetes, Laboulbeniales) parassite di Chrysomelidae (Insecta, Coleoptera). - Natura, Soc. Ital. Sci. Nat. Milano 70: 89-93.

- 1980: Nuovo contributo alla conoscenza delle Laboulbeniali (Ascomycetes) parassiti alla di Stafilinidi italiani (Insecta, Coleoptera). - Giorn. Bot. Ital. 114: 187192.

Rostrup, O. 1916: Bidrag till Danmarks Svampeflora 1. Dansk Bot. Arkiv 2(5): $1-56$.

Ruffieux, L. 1940: 1. Contribution à l'étude de la flore cryptogamique fribourgeoise. Les Champignons observés dans le canton de Fribourg. - Mém. Soc. Fribourg. Sci. Nat., Fribourg 1: 166-214.

Ryberg, O. 1947: Studies on bats and bat parasites, especially with regard to Sweden and other neighbouring countries of the North. -330 pp. Stockholm.

Saccardo, P.A. 1895: Laboulbeniaceae Peyr. - Sylloge Fungorum 11: 446-456.

Savile, D.B.O. 1968: Possible interrelationships between fungal groups. - In: Ainsworth, G.C. \& Sussman, A.S. (eds.), The fungi, an advanced treatise 3: 649-675. New York \& London.

Scheloske, H.-W. 1969: Beiträge zur Biologie, Ökologie und Systematic der Laboulbeniales (Ascomycetes) unter besonderer Berücksichtigung des Parasit-Wirt-Verhältnisses. - Parasitol. Schriftenr. 19: 1-176.

- 1976a: Eusynaptomyces benjaminii, spec. nova, (Ascomycetes, Laboulbeniales) und seine Anpassungen an das Fortpflanzungsverhalten seines Wirtes Enochrus testaceus (Coleoptera, Hydrophilidae). - Plant Syst. Evol. 126: $267-285$.

- 1976b: Morphologische Anpassungen eines ektoparasitischen Pilzes (Ascomycetes: Laboulbeniales: Misgomyces coneglanensis) an Köperbau und Fortpflanzungsverhalten seines Wirtes (Coleoptera: Hydrophilidae: Laccobius minutus). - Entomol. Germ. 3: 227-241.

Schubart, O. 1964: Weichtiere - Krebstiere - Tausendfüssler. Diplopoda, Symphyla, Pauropoda, Chilopoda. Die Tierwelt Mitteleuropas 2(3): 1-51.

Siemaszko, J. \& Siemaszko, W. 1928: Owadorosty polskie i palearktyczne (Laboulbeniales polonici et palaearctici). - Polskie Pismo Entomol. 6: 188-211.

- 1932: Owadorosty polskie i palearktyczne 2 (Laboulbeniales polonici et palaearctici 2). - Polskie Pismo Entomol. 10: 149-188.

- 1933: Owadorosty polskie i palearktyczne 3 (Laboulbeniales polonici et palaearctici 3). - Polskie Pismo Entomol. 12: 115-138.

Silfverberg, H. (ed.) 1979: Enumeratio Coleopterorum Fennoscandiae et Daniae. -79 pp. Helsingin Hyönteisvaihtoyhdistys, Helsinki.

Sorokin, N. 1871: Mycologische Skizzen. - 48 pp. Charkow.

Spegazzini, C. 1912: Contribución al estudio de las Laboulbeniomicetas argentinas. - An. Mus. Nac. Hist. Nat. Buenos Aires 23: 167-244.

- 1914: Primo contributo alla conoscenza delle Laboulbeniali italiani. - Redia 10: $21-75$.

- 1915a: Fungi nonnulli senegalenses et canarienses. - An. Mus. Nac. Hist. Nat. Buenos Aires 26: 117-134.

- 1915b: Laboulbeniali ritrovati nelle collezioni di alcuni musei italiani. - An. Mus. Nac. Hist. Nat. Buenos Aires 26: $451-511$.
- 1915c: Segunda contribución al conocimiento de las Laboulbeniales italianas. - An. Mus. Nac. Hist. Nat. Buenos Aires 27: 37-74.

- 1917: Revision de las Laboulbeniales argentinas. - An. Mus. Nac. Hist. Nat. Buenos Aires 29: 445-688.

- 1918: Observaciones microbiológicas. - An. Soc. Cient. Argent., Buenos Aires 85: 311-323.

Stadelmann, M. \& Poelt, J. 1962: Zur Kenntnis der mitteleuropäischen Laboulbeniales. - Ber. Bayer. Bot. Ges. 35: $120-132$.

Stenius, G. 1936: Beiträge zur Kenntnis der Coleopterenfauna im Kilpisjärvi-Gebiet. - Acta Soc. Fauna Flora Fennica 58(6): $1-18$

Sugiyama, K. 1972: On five species of the Laboulbeniales collected in Peru. - Trans. Mycol. Soc. Japan 13: 260264.

- 1973: Species and genera of the Laboulbeniales (Ascomycetes) in Japan. - Ginkgoana 2: 1-97.

- 1978a: The Laboulbeniomycetes of eastern Asia 1. On two species of Laboulbenia and one new species of Rickia. - J. Japan. Bot. 53: 20-27.

- 1978b: The Laboulbeniomycetes of eastern Asia 2. On eight species from Japan and Formosa including two new species of Rickia. - J. Japan. Bot. 53: 154-160.

- 1978c: The Laboulbeniomycetes of eastern Asia 3. On nine species including two new species. - J. Japan. Bot. 53: $281-288$.

- 1981: Notes on Laboulbeniomycetes of Formosa 3. Trans. Mycol. Soc. Japan 22: 311-319.

Sugiyama, K. \& Hayama, M. 1981: Notes on Laboulbeniomycetes of Formosa 2. - Trans. Mycol. Soc. Japan 22: $187-196$.

Sugiyama, K. \& Shazawa, E. 1977: Notes on Laboulbeniomycetes of Formosa. - Trans. Mycol. Soc. Japan 18: $270-278$.

Tavares, I.I. 1965: Thallus development in Herpomyces paranensis (Laboulbeniales). - Mycologia 52: 704-721.

- 1966: Structure and development of Herpomyces stylopygae (Laboulbeniales). - Amer. J. Bot. 53: 311-318.

- 1967: A new basis for classification of the Laboulbeniales. - Amer. J. Bot. 54: 648.

- 1979: The Laboulbeniales and their arthropod hosts. In: Batra, L.R. (ed.), Insect-fungus symbiosis: nutrition, mutualism and commensalism: 229-258. Montclair, NJ.

- 1980: Notes on perithecial development in the Euceratomycetaceae fam. nov. (Laboulbeniales, Laboulbeniineae) and Herpomyces (Herpomycetineae). - Mycotaxon 11: $485-492$

- 1981a: Notes on Argentinian Laboulbeniales, with the description of a new genus, Benjaminella. - Mycotaxon 12: $431-443$

- 1981b: Validation of the Herpomycetineaea in the Laboulbeniales. - Mycotaxon 13: 469-470.

Tavares, I.I. \& Majewski, T. 1976: Siemaszkoa and Botryandromyces, two segregates of Misgomyces (Laboulbeniales). - Mycotaxon 3: 193-208.

Terada, K. 1981: Osoriomyces, a new genus of the Laboulbeniales from Taiwan. - Mycotaxon 13: 412-418.

Thaxter, R. 1890: On some North American species of Laboulbeniaceae. - Proc. Amer. Acad. Arts \& Sci. 25: $5-14$.

- 1891: Supplementary note on North American Laboulbeniaceae. - Proc. Amer. Acad. Arts \& Sci. 25: 261270.

- 1892: Further additions to the North American species of Laboulbeniaceae. - Proc. Amer. Acad. Arts \& Sci. 27: 29-45.

- 1893: New species of Laboulbeniaceae from various localities. - Proc. Amer. Acad. Arts \& Sci. 28: 156-188.

- 1894: New genera and species of Laboulbeniaceae, with a synopsis of the known species. - Proc. Amer. Acad. Arts \& Sci. 29: 92-111.

- 1895: Notes on Laboulbeniaceae, with descripions of new species. - Proc. Amer. Acad. Arts \& Sci. 30: 467-481.

- 1896: Contribution towards a monograph of hte Laboulbeniaceae. - Mem. Amer. Acad. Arts \& Sci. 12: 187429. 
- 1914: On certain peculiar fungus-parasites of living insects. - Bot. Gaz. 58: 235-253.

- 1915: New Indo-Malayan Laboulbeniales. - Proc. Amer. Acad. Arts \& Sci. 51: 1-51.

- 1917: New Laboulbeniales, chiefly Dipterophilous American species. - Proc. Amer. Acad. Arts \& Sci. 52: 647-721.

- 1918: Extra-American dipterophilous Laboulbeniales. Proc. Amer. Acad. Arts \& Sci. 53: 695-749.

- 1920: Second note on certain peculiar fungus-parasites of living insects. - Bot. Gaz. 69: 1-27.

- 1924: Contribution towards a monograph of the Laboulbeniaceae 3. - Mem. Amer. Acad. Arts \& Sci. 14: 309426.

- 1931: Contribution towards a monograph of the Laboulbeniaceae 5. - Mem. Amer. Acad. Arts \& Sci. 16: 1435.

Whisler, H.C. 1968: Experimental studies with a new species of Stigmatomyces (Laboulbeniales). - Mycologia 60: $65-75$.

Wirth, W.W. 1975: A revision of the brine flies of of the genus Ephydra of the Old World (Diptera: Ephydridae). - Ent. Scand. 6: 11-44.
Wize, K. 1929: Przyczynek dotyczacy flory owadorostów w Polsce. (Contribution à la flore de Laboulbéniales en Pologne.) - Polskie Pismo Entomol. 7: 192-193.

- 1899: Preliminary diagnoses of new species of Laboulbeniaceae 1. - Proc. Amer. Acad. Arts \& Sci. 35: 153209.

- 1900: Preliminary diagnoses of new species of Laboulbeniaceae 2. - Proc. Amer. Acad. Arts \& Sci. 35: 407450.

- 1901a: Preliminary diagnoses of new species of Laboulbeniaceae 3. - Proc. Amer. Acad. Arts \& Sci. 36: 395414.

- 1901b: Preliminary diagnoses of new species of Laboulbeniaceae 4. - Proc. Amer. Acad. Arts \& Sci. 37: 1945.

- 1902: Preliminary diagnoses of new species of Laboulbeniaceae 5. - Proc. Amer. Acad. Arts \& Sci. 38: 7-57.

- 1908: Contribution towards a monograph of the Laboulbeniaceae 2. - Mem. Amer. Acad. Arts \& Sci. 13: 217469.

- 1912: New or critical Laboulbeniales from the Argentine. - Proc. Amer. Acad. Arts \& Sci. 48: 153-223. 


\section{Appendix 1}

Total number of investigated arthropod specimens. An asterisk (*) indicates occurrence of ectoparasitic fungi. Nomenclature principally according to Albrecht (1979), Collingwood (1979), Hackman (1980), Kloet \& Hincks (1964), Schubart (1964) and Silfverberg (1979).

\section{INSECTA}

C O LEOPTERA

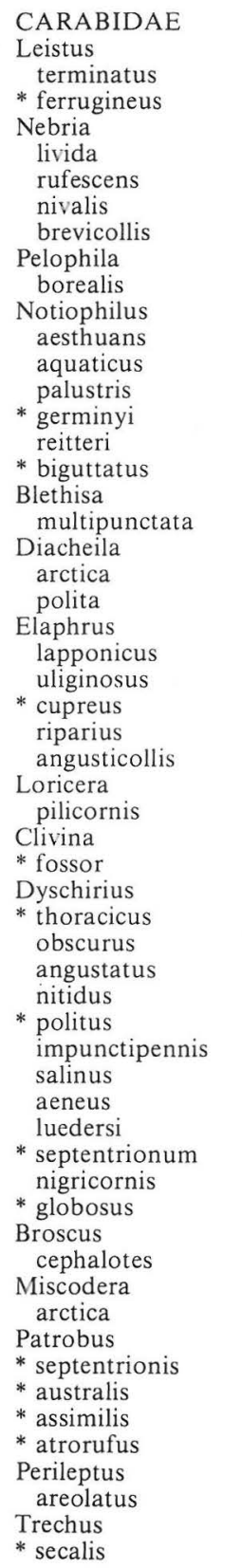

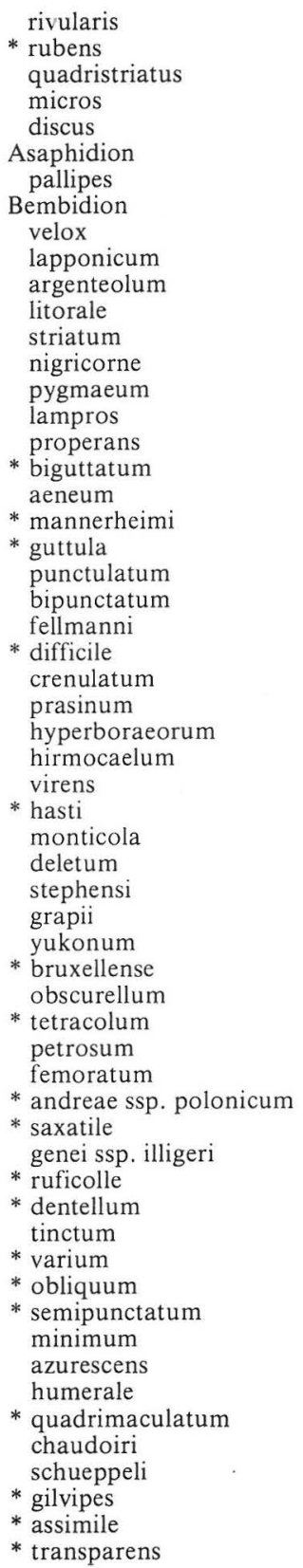

$\begin{array}{rlr}107 & * \text { doris } & 100 \\ 311 & * \text { articulatum } & 29 \\ 422 & \text { octomaculatum } \\ 15 & \text { Tachys } \\ 114 & \text { bistriatus } \\ & \text { bisulcatus } \\ 264 & \text { nanus } & \\ & \text { Stomis } & \\ 555 & \text { pumicatus } \\ 172 & \text { Pterostichus }\end{array}$

terostichus
lepidus

cupreus

versicolor

vernalis

aterrimus

adstrictus

oblongopunctatus

quadrifoveolatus

niger

melanarius

* nigrita

anthracinus

gracilis

* minor

* strenuus

* diligens middendorffi brevicornis aethiops madidus

Calathus

fuscipes

* erratus

ambiguus

* melanocephalus

* micropterus

Sphodrus leucophthalmus

Laemostenus terricola

Synuchus vivalis

Olistophus rotundatus

Agonum

bogemanni

* quadripunctatum micans

* fuliginosum

piceum

* gracile

exaratum

munsteri

consimile

* thorey

impressum

sexpunctatum

ericeti

gracilipes
1004 


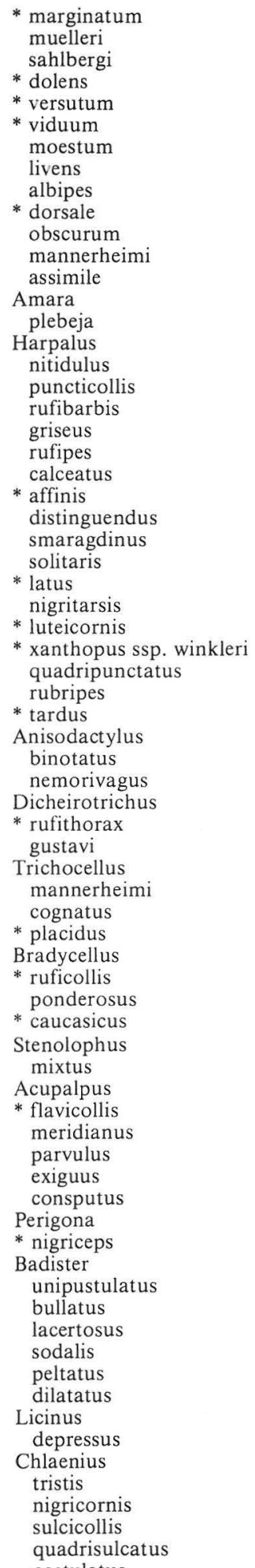

Oodes

* helopioides

Panagaeus

cruxmajor

bipustulatus

Odacantha

Lebia

cyanocephala

chlorocephala

cruxminor

Demetrias

monostigma

Dromius

longiceps

* linearis

agilis

quadraticollis

schneideri

fenestratus

quadrimaculatus

spilotus

sigma

notatus

Syntomus

* truncatellus

foveatus

Microlestes

minutulus

maurus

Cymindis

angularis

macularis

vaporariorum

Brachinus

crepitans

11

1

22

188

2
75

50

\section{HALIPLIDAE}

\section{Brychius}

Haliplus

varius

obliquus

confinis

ruficollis

heydeni

fluviatilis

wehnkei

interjectus

sahlbergi

* lineolatus

immaculatus

* fulvicollis

flavicollis

fulvus

* ssp. fulvus

* ssp. lapponum

\section{DYTISCIDAE}

Laccophilus

hyaline

* minutus

stroehmi

Hyphydrus

ovatus

Bidessus

unistriatus

grossepunctatus

Guignotus melanura

elevatus ssp. cristatus

variegatus

80 pusillus

hamulatus

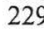

Hygrotus

decoratus

* inaequalis

versicolor

quinquelineatus

Coelambus

impressopunctatus

novemlineatus

marklini

Hydroporus

dorsalis

lapponum

erythrocephalus

\section{GYRINIDAE}

Gyrinus

* marinus

* aeratus

* pullatus

opacus

* distinctus

* natator

* substriatus

suffriani

* paykulli

* minutus

Orectochilus

villosus

\section{HYDRAENIDAE}

Ochthebius

bicolon

* minimus

marinus

Hydraena

palustris

britteni

riparia

pulchella

gracilis

Limnebius

truncatellus

truncatulus

crinifer

nitidus

aluta

\section{HYDROPHILIDAE}

Hydrochus ignicollis

brevis

Spercheus emarginatus

Helophorus nubilus tuberculatus

Cercyon

littoralis

depressus

ustulatus

lugubris

impressus

haemorrhoidalis

melanocephalus

limbata 


Laccobius
decorus
minutus
biguttatus
striatulus
bipunctatus
Helochares
obscurus
Enochrus
melanocephalus
ochropterus
quadripunctatus
bicolor
testaceus
affinis
coarctatus
sp.
Cymbiodyta
marginella
Chaetarthria
seminulum
Hydrochara
caraboides
Hydrophilus
piceus
aterrimus
Berosus
spinosus
luridus

\section{PTILIIDAE}

Ptenidium

* laevigatum

fuscicorne

punctatum

formicetorum

pusillum

nitidum

Nephanes

titan

Acrotrichis

grandicollis

chevrolati

thoracica

sericans

dispar

brevipennis

pumila

silvatica

parva

cognata

norvegica

intermedia

atomaria

lucidula

sitkaensis

fascicularis

rugulosa

strandi

* sp. ()

\section{LEIODIDAE \\ Leiodes \\ punctulata \\ inordinata \\ ciliaris \\ rubiginosa \\ triepkii \\ rugosa}

$\begin{aligned} & \text { puncticollis } \\ 299 & \text { hybrida } \\ 607 & \text { rhaetica } \\ 55 & \text { oblonga } \\ 7 & \text { silesiaca } \\ 45 & \text { lucens } \\ & \text { curta } \\ 143 & \text { calcarata } \\ & \text { picea } \\ 103 & \text { dubia } \\ 256 & \text { obesa } \\ 898 & \text { nigrita } \\ 176 & \text { litura } \\ 248 & \text { ovalis } \\ 423 & \text { badia } \\ 157 & \text { parvula } \\ 32 & \text { Colenis } \\ & \text { immunda } \\ 90 & \text { Cyrtusa } \\ & * \text { subtestacea } \\ 172 & \text { pauxilla } \\ 39 & \text { minuta } \\ & \text { Amphicyllis } \\ 4 & \text { globosus } \\ 2 & \text { globiformis } \\ & \text { Agathidium } \\ & \text { nigripenne } \\ 257 & \text { seminulum } \\ & \\ & \end{aligned}$

SILPHIDAE

Thanatophilus

rugosus

sinuatus

dispar

Oiceoptoma

thoracica

Phosphuga

atrata

Pteroloma

forsstroemi

CATOPIDAE

Ptomaphagus

* subvillosus

Nemadus

colonoides

Nargus

velox

badius

Choleva

* septentrionis

oblonga

glauca

angustata

sturmi

spinipennis

elongata

Dreposcia

brevipalpis

Sciodrepoides

* watsoni

fumatus

Catops

subfuscus

* alpinus

luteipes

coracinus

tristis

morio

* nigrita

$\begin{array}{rlr}4 & \text { nigriclavis } & 14 \\ 10 & \text { westi } & 8 \\ 12 & \text { * fungus } & 190 \\ 4 & \text { * fuliginosus } & 14 \\ 33 & \text { borealis } & 12 \\ 6 & \text { * nigricans } & 56 \\ 5 & & \end{array}$

\section{COLONIDAE}

Colon

latum

pseudolatum 4

arcticum

angulare

dentipes

barnevillei

brunneum

appendiculatum

bidentatum

14
8
90
14
12
56

SCYDMAENIDAE

Eutheia

scydmaenoides $\quad 42$

Nevraphes

angulatus $\quad 57$

64

169

Stenichnus

scutellaris

collaris

SCAPHIDIIDAE

Scaphisoma

* agaricinum 240

* inopinatum 67

boleti 22

subalpinum 47

balcanicum 6

boreale 18

assimile 19

STAPHYLINIDAE

Staphylininae

Erichsonius

$28 \quad$ * cinerascens 355

46 rectangulus 134

* discoideus 41

quisquiliarius $\quad 247$

corvinus 170

sanguinolentus $\quad 155$

scoticus $\quad 61$

$\begin{array}{lr}\text { diversipennis } & 6 \\ * \text { ventralis } & 109\end{array}$

* rigidicornis 167

* puella 158

laminatus $\quad 152$

politus 334

succicola 210

addendus 64

nitidus 127

rotundicollis $\quad 117$

tenuicornis 114

decorus $\quad 100$

cognatus 159

* subuliformis 7

nigriventris 87

pachycephalus 273

$\begin{array}{lr}\text { parcus } & 1 \\ * \text { cephalotes } & 447\end{array}$

* cruentatus 138 


confinis
marginatus
varians
atratus
subvirescens
carbonarius
* albipes
caucasicus
ebeninus
ochropus
* debilis
splendens
punctus
fumarius
* umbratilis
nigrita
nitidulus
lepidus
* longicornis
agilis
furcifer
* micans
* rubripennis
tenuis
Gabronthus
thermarum
Gabrius
vernalis
lividipes
expectatus
splendidulus
bescidicus
* trossulus
sphagnicola
nigritulus
velox
pennatus
subnigritulus
toxotes
Heterothops
praevius
quadripunctulus
Quedius
brevis
microps
longicornis
puncticollis
nigrocaeruleus
assimilis
cruentus
brevicornis
* mesomelinus
maurus
xanthopus
scitus
tenellus
* cinctus
plagiatus
fuliginosus
curtipennis
subunicolor
molochinus
picipes
umbrinus/pseudoumbrinus
nigripes
sublimbatus
* limbatus
maurorufus
scintillans
lucidulus
nitipennis
* fulvicollis

\begin{tabular}{|c|c|}
\hline & \\
\hline 25 & fellmanni \\
\hline $\begin{array}{l}161 \\
375\end{array}$ & $\begin{array}{l}\text { boopoides } \\
\text { * boops }\end{array}$ \\
\hline 114 & Acylophorus \\
\hline 126 & wagenschieberi \\
\hline 193 & \\
\hline 291 & Xantholininae \\
\hline 6 & Othius \\
\hline 25 & ${ }^{*}$ punctulatus \\
\hline 291 & angustus \\
\hline 312 & volans \\
\hline 92 & * lapidicola \\
\hline 4 & myrmecophilus \\
\hline 1 & Paederinae \\
\hline
\end{tabular}

$\begin{array}{rlr}6 & \text { Oxytelinae } & \\ 36 & \text { Carpelimus } & 30 \\ 244 & \text { arcuatus } & 131 \\ & \text { bilineatus } & 254 \\ 175 & \text { rivularis } & 3 \\ & \text { obesus } & 5 \\ & \text { fuliginosus } & 2 \\ & \text { impressus } & 289 \\ 85 & \text { * corticinus } & 136 \\ 19 & \text { foveolatus } & 19 \\ 6 & \text { despectus } & 118 \\ 191 & \text { pusillus } & 23 \\ 157 & \text { gracilis } & 105 \\ & \text { elongatulus } & \\ 196 & \text { Aploderus } & 170 \\ 378 & \text { caelatus } & 2 \\ & \text { * caesus } & \end{array}$

Paederus
fuscipes

riparius 378

Astenus procerus pulchellus gracilis

Rugilus scutellatus

rufipes

* similis orbiculatus erichsoni

Lithocharis obscurella ochracea nigriceps

Scopaeus laevigatus minutus pusillus

Lathrobium punctatum sphagnetorum terminatum fennicum quadratum rufipenne elongatum geminum fulvipenne brunnipes fovulum filiforme

* longulum

Ochthephilum fracticorne

Omaliinae

Xylodromus depressus concinnus

Micralymma

* marinum

Cylletron nivale

Lesteva longoelytra monticola

Psephidonus plagiatus longipes

sculptus

* fulvipes

* piceus

* laqueatus

Anotylus

* insecatus

* rugosus

sculpturatus

* nitidulus

pumilus

hamatus

fairmairei

clavatus

tetracarinatus

tetratoma

Platystethus

* arenarius

cornutus

alutaceus

capito

nodifrons

nitens

Bledius

dama

* diota

germanicus

tricornis

litoralis

defensus

fuscipes

* kutsae

* arcticus

terebrans

* filipes

* poppiusi

fennicus

* vilis

* longulus

denticollis

* opacus

* gallicus

dissimilis crassicollis
Oxyporinae
Oxyporus
rufus
mannerheimi maxillosus

Aleocharinae

Dochmonota 
fallax

Hydrosmecta

thinobioides

Dilacra

luteipes

vilis

Schistoglossa

gemina

Aloconota

currax

sulcifrons

insecta

gregaria

languida

Liogluta

pagana

granigera

longiuscula

microptera

oblongiuscula

alpestris

Geostiba

circellaris

Paranopleta

inhabilis

Dimetrota

cadaverina

Atheta

arctica

polaris

elongatula

hygrobia

hygrotopora

luridipennis

terminalis

gyllenhali

melanocera

malleus

volans

palustris

debilis

britteni

ripicola

fallaciosa

talpa

amicula

spatuloides

inquinula

excelsa

subtilis

nesslingi

liliputana

boreella

zosterae

nigra

dadopora

canescens

sordidula

celata

myrmecobia

laticollis

clientula

orphana

orbata

fungi

lateralis

sodalis

gagatina

pallidicornis

trinotata

sparreschneideri

subglabra
6

77

20

79

38

1
43

72
255

255
2

1

46

46
5
360

74

101

715

4

9

552

64

200

127

2
29

29

78

765

153

30

155

82

135

41

131

301

2

15

15
267

1

6
74

74
124

61

52

243

110

335

145

25

19

110
1674

135

532

163

17

220

1 macrocera

puncticollis

$*$ longicornis

cribripennis

subsinuata

$\mathrm{d}$ winensis

munsteri

islandica

eremita

fusca

latifemorata

nigripes

livida

cinnamoptera

picipennis

picipennoides

lapponica

altaica

intermedia

cauta

inchnocera

setigera

laevana

atramentaria

hypnorum

laevicauda

brunneipennis

xanthopus

graminicola

ebenina

incognita

procera

basicornis

nidicola

allocera

oblita

autumnalis

boletophila

diversa

strandiella

pilicornis

boleticola

* crassicornis/paracrassicornis

euryptera

divisa

frigida

liturata

nigricornis

harwoodi

coriaria

dubiosa

brunnea

nigritula

picipes

corvina

depressicollis

occulta

monticola

excellens

vestita

Alianta

nigella

Dinaraea

angustula

aequata

linearis

arcana

Acrotona

sordida

exigua

sylvicola

pygmaea

$\begin{array}{rcr}188 & \text { obfuscata } & 5 \\ 1 & \text { muscorum } & 5 \\ 477 & \text { aterrima } & 411 \\ 15 & \text { parvula } & 237 \\ 140 & \text { Coprothassa } & \\ 8 & \text { melanaria } & 99 \\ 4 & \text { Pachyatheta } & 2 \\ 68 & \text { mortuorum } & 47 \\ 20 & \text { cribrata } & 2 \\ 20 & \text { Silusa } & \\ 1 & \text { rubiginosa } & 76 \\ 92 & \text { Anomognathus } & \\ 125 & \text { cuspidatus } & 83 \\ 115 & \text { Homalota } & \end{array}$

232

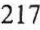

PSELAPHIDAE

Bibloporus

bicolor

minutus

Bibloplectus

tenebrosus

spinosus

ambiguus

Euplectus

nanus

piceus

decipiens

bescidicus

sanguineus

signatus

punctatus

karsteni

brunneus

Trimium

brevicorne

Batrisodes

hubenthali

adnexus

Bythinus

macropalpus

Bryaxis

puncticollis

bulbifer

Tychus

niger

Rybaxis

longicornis

Brachygluta

* fossulata

haematica

helferi

Trissemus

impressus

Pselaphaulax

dresdensis

Pselaphus

heisei

Tyrus

mucronatus

Claviger

testaceus

HISTERIDAE

Hister

2

5

2

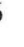

83

32

5

列

(8)




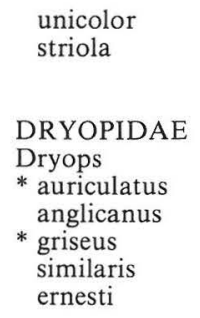

\section{HETEROCERIDAE}

Heterocerus

flexuosus

obsoletus

marginatus

fenestratus

fusculus

hispidulus

intermedius

\section{CUCUJIDAE}

Silvanus

bidentatus

unidentatus

Cucujus

cinnaberinus

haematodes

\section{CRYPTOPHAGIDAE}

Telmatophilus

caricis

typhae

schoenherri

Paramecosoma

melanocephalum

Henoticus

serratus

californicus

Pteryngium

crenatum

Cryptophagus

* bimaculatus

lindbergorum

abietis

longitarsis

acutangulus

angustus

fallax

badius

populi

lysholmi

plagiatus

confertus

lapponicus

subdepressus

instabilis

subfumatus

pubescens

saginatus

fuscicornis

labilis

confusus

pseudodentatus

distinguendus

corticinus

scanicus

pallidus

\section{ENDOMYCHIDAE}

Sphaerosoma

pilosum

Mycetaea

subterranea

\section{COCCINELLIDAE}

Chilocorus

bipustulatus

renipustulatus

\section{CORYLOPHIDAE}

Orthoperus

punctulatus

atomus

brunnipes

10

4

CISIDAE

Octotemnus

glabriculus

mandibularis

\section{COLYDIIDAE}

Myrmechixenus

subterraneus

vaporariorum

Orthocerus

clavicornis

\section{ANTHICIDAE}

Notoxus

monoceros

Anthicus

axillaris

ater

umbrinus

flavipes

antherinus

* floralis

* formicarius

gracilis

sellatus

bimaculatus

TENEBRIONIDAE

Scaphidema

metallicum

D I P T E R A

DROSOPHILIDAE

Drosophila

funebris

fenestrarum
Scaptomyza

graminum

unipunctum

* pallida

\section{CAMILLIDAE}

Camilla

atripes

glabra

glabrata
35

68

\section{DIASTATIDAE}

Campichoeta

griseola

Diastata

fuscula

nebulosa

146

298

unipuncta

vagans

EPHYDRIDAE

Mosillus

subsultans

23
105
49

Allotrichoma

laterale

Athyroglossa

glabra

Atissa

lisomina

94

13

Glenanthe fuscinervis ripicola

Discocerina obscurella

Polytrichophora duplosetosa

Ditrichophora

aurifacies

102

aurivillii

cinerella

plumosa

psilopina

Discomyza

incurva

Psilopa

compta

leucostoma

marginella

nitidula

polita

pulicaria

Trimerina

madizans

Notiphila

annulipes

aquatica

brunnipes

cinerea

dorsata

110

maculata

riparia

stagnicola

uliginosa

sp.

Dichaeta

* caudata

Hydrellia

albiceps

77
6

1

1

10

11

5

36

4
6

108

11
92

26

150

15

12

25

23

34

1
197

23

160

30 


argyrogenis
baltica
concolor
diadema
* flaviceps
flavicornis
fusca
* griseola
* incana
lapponica
nymphaeae
obscura
pilitarsis
Ilythea
spilota
Philygria
flavipes
nigricauna
obtecta
posticata
sexmaculata
Nostima
picta
Parydra
aquila
coarctata
fossarum
nubecula
pusilla
quadripunctata
Axysta
* cesta
Hyadina
guttata
humeralis
nitida
Pelina
aenea
aenescens
Eutaenionotum
guttipennis
Ochthera
* manicata
* mantis
Ephydra
macellaria
* riparia
* scholtzi
Setacera
aurata
* micans
Limnellia
fallax
quadrata
stenhammari
Philotelma
nigripennis
dichaeta
sibilans
*atella
callosicosta
crassicosta
lutosa
paludum
silacea
* stagnalis
subguttata
tenuicosta
Scatophila
caviceps
contaminata

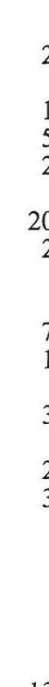

cribrata

despecta

flavitarsis

variegata

Coenia

palustris

Paracoenia

fumosa

\section{HETEROMYZIDAE}

Heteromyza

oculata

Tephrochlamys

flavipes

rufiventris

tarsalis

\section{FANNIIDAE}

Fannia

canicularis

difficilis

fuscula

genualis

glaucescens

hamata

hirticeps

hirundinis

incisurata

limbata

lugubrina

manicata

minutipalpis

monilis

mutica

nodulosa

pallitibia

parva

polychaeta

postica

pretiosa

ringdahlana

scalaris

serena

similis

sociella

speciosa

tuberculata

\section{MUSCIDAE}

Morellia

hortorum

Musca

autumnalis

* domestica

tempestiva

SARCOPHAGIDAE

Sarcophaga

carnaria

CALLIPHORIDAE

\section{Pollenia}

rudis

Phormia

terraenovae

HIPPOBOSCIDAE

Melophagus

ovinus

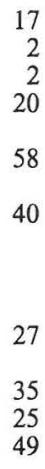

17

2

20

58

40

\section{Copromyza}

nitida

* borealis

stercoraria

Thoracochaeta zosterae

Limosina

* claviventris

clunipes

* schmitzi

* talparum

parvula

Leptocera

fontinalis

H Y M E N O P T E R A

\section{FORMICIDAE}

Ponera

punctatissima

Myrmica

rubra

ruginodis

sulcinodis

gallieni

rugulosa

scabrinodis

schencki

lobicornis

sabuleti

Leptothorax

acervorum

muscorum

tuberum

Lasius

$\begin{array}{lr}\text { fuliginosus } & 90 \\ \text { niger } & 1124 \\ \text { alienus } & 221 \\ \text { flavus } & 120\end{array}$

H E T E R O P T E R A

\section{CORIXIDAE}

Hesperocorixa

linnei
sahlbergi
Corixa
dentipes
Paracorixa


concinna

Arctocorisa

carinata

Callicorixa

producta

\section{HEBRIDAE}

Hebrus

pusillus

ruficeps

D E R M A P T E R A

\section{LABIIDAE}

Labia

minor
25

50

FORFICULIDAE

Forficula

auricularia

50

B L A T T O DE A

PSEUDOMOPIDAE

Ectobius

96 lapponicus

silvestris

Blattella

germanica

BLATTIDAE

Periplaneta

americana

\section{DIPLOPODA}

335

BLANIULIDAE

Isobates

varicornis

10

\section{JULIDAE}

380 terrestris

249 Leptoiulus

minutus

60

55

Schizophyllum

sabulosum

sp.

55 


\section{Appendix 2}

Host-parasite list of the East Fennoscandian Laboulbeniales. Abbreviations: $\Sigma=$ total number of investigated host specimens; $\Sigma$ inf. = total number of infested host specimens; \%inf. = frequency of infested host specimens. The figures for Central Europe (in cases when the host taxon is the same in East Fennoscandia) are according to Scheloske (1969). In cases when more than one parasite species occur on a host, the number of infested host specimens are given in brackets for each parasite species. The \%inf. for Gyrinidae (Coleoptera) concerns only randomly collected specimens. The figures for Patrobus atrorufus, Agonum viduum and Gyrinus spp. are not up to date in comparison with the data given under Laboulbenia fasciculata, L. flagellata and $L$. fennica respectively in section 8.3 .

\begin{tabular}{|c|c|c|c|c|}
\hline $\begin{array}{l}\text { Host species } \\
\text { COLEOPTER A }\end{array}$ & $\Sigma$ & Einf. & \%inf. & $\begin{array}{l}\text { Central } \\
\text { Europe }\end{array}$ \\
\hline CARABIDAE & 62713 & 687 & $1.1 \%$ & $33.2 \%$ \\
\hline Nebriini & 1597 & 3 & $0.2 \%$ & $21.0 \%$ \\
\hline \multicolumn{5}{|l|}{ Leistus } \\
\hline ferrugineus (Linnaeus) & 268 & 3 & $1.1 \%$ & $28.6 \%$ \\
\hline Notiophilini & 1884 & 15 & $0.8 \%$ & $1.4 \%$ \\
\hline \multicolumn{5}{|l|}{ Notiophilus } \\
\hline germinyi Fauvel & 426 & 2 & $0.5 \%$ & \\
\hline biguttatus (Fabricius) & 379 & 13 & $3.4 \%$ & 0 \\
\hline Elaphrini & 2174 & 19 & $0.9 \%$ & 0 \\
\hline \multicolumn{5}{|l|}{ Elaphrus } \\
\hline cupreus Duftschmid & 665 & 19 & $2.9 \%$ & 0 \\
\hline Scaritini & 4714 & 122 & $2.6 \%$ & $59.4 \%$ \\
\hline \multicolumn{5}{|l|}{ Clivina } \\
\hline fossor (Linnaeus) & 595 & 38 & $6.4 \%$ & $67.9 \%$ \\
\hline \multicolumn{5}{|l|}{ Dyschirius } \\
\hline thoracicus (Rossi) & 1082 & 5 & $0.5 \%$ & \\
\hline politus (Dejean) & 94 & 1 & $1.1 \%$ & \\
\hline septentrionum Munster & 383 & 11 & $2.9 \%$ & \\
\hline globosus (Herbst) & 1521 & 67 & $4.4 \%$ & $58.2 \%$ \\
\hline Patrobini & 1772 & 106 & $5.9 \%$ & $66.5 \%$ \\
\hline \multicolumn{5}{|l|}{ Patrobus } \\
\hline septentrionis Dejean & 655 & 3 & $0.5 \%$ & \\
\hline australis J. Sahlberg & 44 & 7 & $15.9 \%$ & \\
\hline assimilis Chaudoir & 692 & 9 & $1.3 \%$ & \\
\hline atrorufus (Ström) & 381 & 87 & $22.8 \%$ & $66.5 \%$ \\
\hline Trechini & 1619 & 3 & $0.2 \%$ & $1.7 \%$ \\
\hline \multicolumn{5}{|l|}{ Trechus } \\
\hline secalis (Paykull) & 648 & 1 & $0.2 \%$ & $2.1 \%$ \\
\hline rubens (Fabricius) & 311 & 2 & $0.6 \%$ & \\
\hline Bembidiini & 15155 & 135 & $0.9 \%$ & $19.3 \%$ \\
\hline \multicolumn{5}{|l|}{ Bembidion } \\
\hline biguttatum (Fabricius) & 169 & 1 & $0.6 \%$ & $28.6 \%$ \\
\hline mannerheimi Sahlberg & 439 & 7 & $1.6 \%$ & \\
\hline guttula (Fabricius) & 720 & 8 & $1.0 \%$ & $31.3 \%$ \\
\hline difficile (Motschulsky) & 288 & 4 & $1.4 \%$ & \\
\hline hasti Sahlberg & 334 & 12 & $3.6 \%$ & \\
\hline bruxellense Wesmaël & 1748 & 30 & $1.7 \%$ & $43.8 \%$ \\
\hline $\begin{array}{l}\text { tetracolum Say } \\
\text { andreae (Fabricius) }\end{array}$ & 309 & 13 & $4.2 \%$ & \\
\hline ssp. polonicum Müller & 219 & 3 & $1.4 \%$ & \\
\hline saxatile Gyllenhal & 453 & 12 & $2.7 \%$ & \\
\hline ruficolle (Panzer) & 134 & 1 & $0.8 \%$ & \\
\hline dentellum (Thunberg) & 345 & 6 & $1.7 \%$ & \\
\hline varium (Olivier) & 46 & 3 & $6.5 \%$ & $5.6 \%$ \\
\hline obliquum Sturm & 1186 & 19 & $1.6 \%$ & $1.8 \%$ \\
\hline semipunctatum Donovan & 238 & 6 & $2.5 \%$ & \\
\hline
\end{tabular}

\%inf. in

$1.0 \%$

6\% Laboulbenia leisti

Laboulbenia notiophili

Laboulbenia notiophili

0

67.9\% Laboulbenia clivinalis

Laboulbenia pedicellata Misgomyces dyschirii Misgomyces dyschirii

(8) Misgomyces dyschirii

(3) Laboulbenia pedicellata

$58.2 \%$ (60) Laboulbenia pedicellata
(13) Misgomyces dyschirii

(1) Laboulbenia fasciculata

(1) Laboulbenia pseudomasei

(1) Laboulbenia flagellata Laboulbenia fasciculata

(7) Laboulbenia fasciculata

(2) Laboulbenia pseudomasei Laboulbenia fasciculata

Laboulbenia polyphaga Laboulbenia vulgaris

Laboulbenia vulgaris Laboulbenia vulgaris Laboulbenia vulgaris Laboulbenia vulgaris

(7) Laboulbenia hastiana n.sp.

(5) Laboulbenia vulgaris Laboulbenia vulgaris Laboulbenia vulgaris

Laboulbenia vulgaris Laboulbenia vulgaris Laboulbenia pedicellata

(5) Laboulbenia vulgaris

(1) Laboulbenia curtipes Laboulbenia curtipes Laboulbenia curtipes

(3) Laboulbenia curtipes

(3) Laboulbenia pedicellata 


\section{Host species}

quadrimaculatum

(Linnaeus)

gilvipes Sturm

assimile Gyllenhal

transparens (Gebler)

doris (Panzer)

articulatum (Panzer)

Pterostichini

Pterostichus

nigrita (Paykull)

minor (Gyllenhal)

strenuus (Panzer)

diligens (Sturm)

Calathus

erratus (Sahlberg)

melanocephalus (Linnaeus)

micropterus (Duftschmid)

Agonum

quadripunctatum (Degeer)

fuliginosum (Panzer)

gracile (Gyllenhal)

thorey Dejean

marginatum (Linnaeus)

dolens (Sahlberg)

versutum Sturm

viduum (Panzer)

dorsale (Pontoppidan)

Harpalini

Harpalus

affinis (Schrank)

latus (Linnaeus)

luteicornis (Duftschmid)

xanthopus Gemminger \& Harold ssp. winkleri Schauberger

tardus (Panzer)

Dicheirotrichus

rufithorax (Sahlberg)

Trichocellus

placidus (Gyllenhal)

Bradycellus

ruficollis (Stephens)

caucasicus Chaudoir

Acapalpus

flavicollis (Sturm)

Perigonini

Perigona

nigriceps (Dejean)

Oodini

Oodes

helopioides (Fabricius)

Lebiini

Dromius

linearis (Olivier)

Syntomus

truncatellus (Linnaeus)

HALIPLIDAE

Haliplus

lineolatus Mannerheim

fulvicollis Erichson

ssp. fulvus (Fabricius)

ssp. lapponum Thomson

DYTISCIDAE \%inf. in

Central

$\Sigma \quad$ sinf. \%inf. Europe

$\begin{array}{rrr}1000 & 2 & 0.2 \% \\ 466 & 2 & 0.4 \% \\ 38 & 2 & 5.3 \% \\ 216 & 1 & 0.5 \% \\ 1004 & 3 & 0.3 \% \\ & & \\ 291 & 1 & 0.3 \% \\ 19537 & 84 & 0.4 \% \\ 792 & 14 & 1.8 \% \\ 521 & 4 & 0.8 \% \\ 838 & 3 & 0.4 \% \\ 1228 & 27 & 2.2 \%\end{array}$

653

1166

1159

302

847

749

449

216

291

338

740

97

7442

1159

780

$36.0 \%$

$63.6 \%$

$15.7 \%$

$8.8 \%$

$36.8 \%$

\section{$26.2 \%$}

$53.4 \%$

$41.2 \%$

$17.9 \%$ (26)

$7.7 \%$
$25.4 \%$

$46.2 \%$

$44.4 \%$

$31.3 \%$

$16.8 \%$ (15) Laboulbenia compressa
(14) Laboulbenia filifera
(1) Laboulbenia compressa
(1) Laboulbenia ophoni Laboulbenia ophoni

(1) Laboulbenia compressa

(1) Laboulbenia ophoni

(2) Laboulbenia compressa

(2) Laboulbenia ophoni

Laboulbenia giardii

Laboulbenia bradycelli

Laboulbenia polyphaga

Laboulbenia polyphaga

Laboulbenia polyphaga

Laboulbenia manubriolata

Laboulbenia oodiphila

$7.7 \%$

0 Laboulbenia pulchella

Laboulbenia metableti

Hydraeomyces halipli Hydraeomyces halipli

$0.1 \%$

$10.2 \%$
Hydraeomyces halipli Hydraeomyces halipli 


\section{Host species}

Laccophilus minutus (Linnaeus)

Hygrotus

inaequalis (Fabricius)

GYRINIDAE

Gyrinus

marinus Gyllenhal

aeratus Stephens

pullatus Zaitzev

distinctus Aubé

natator (Linnaeus)

paykulli Ochs

substriatus Stephens

minutus Fabricius

HYDRAENIDAE

Ochthebius

minimus (Fabricius)

PTILIIDAE

Ptenidium

laevigatum Erichson

Acrotrichis

sp. (O)

LEIODIDAE

Cyrtusa

subtestacea (Gyllenhal)

CATOPIDAE

Ptomaphagus

subvillosus (Goeze)

Choleva

septentrionis Jeannel

Sciodrepoides

watsoni (Spence)

Catops

alpinus Gyllenhal

nigrita Erichson

fuscus (Panzer)

fuliginosus Erichson

nigricans (Spence)

SCAPHIDIIDAE

Scaphisoma

agaricinum (Linnaeus)

inopinatum Löbl

STAPHYLINIDAE

Staphylininae

Erichsonius

cinerascens (Gravenhorst)

Philonthus

discoideus (Gravenhorst)

ventralis (Gravenhorst)

rigidicornis (Gravenhorst)

puella Nordmann

subuliformis (Gravenhorst)

cephalotes (Gravenhorst)

cruentatus (Gmelin)

albipes (Gravenhorst)

debilis (Gravenhorst)

umbratilis (Gravenhorst)

longicornis Stephens

micans (Gravenhorst)

rubripennis Stephens \%inf. in

Central

$\Sigma \quad$ Sinf. \%inf. Europe

Parasite species

$\begin{array}{rrrrr}100 & 3 & 3.0 \% & 16.9 \% & \begin{array}{l}\text { (2) } \begin{array}{l}\text { Chitonomyces melanurus } \\ \text { (1) }\end{array} \\ \text { Chitonomyces paradoxus }\end{array} \\ 720 & 2 & 0.3 \% & 26.6 \% & \text { Chitonomyces bidessarius } \\ 7869 & 766 & (0.9 \%) & 0 & \\ 550 & 21 & & 0 & \begin{array}{l}\text { Laboulbenia fennica n.sp. } \\ \text { Laboulbenia fennica n.sp. }\end{array} \\ 3522 & 657 & & & \begin{array}{l}\text { Laboulbenia fennica n.sp. } \\ 977\end{array} \\ 443 & 19 & & & \begin{array}{l}\text { Laboulbenia fennica n.sp. } \\ 256\end{array} \\ 25 & & & \begin{array}{l}\text { Laboulbenia fennica n.sp. } \\ \text { Laboulbenia fennica n.sp. }\end{array} \\ 207 & 1 & & & \begin{array}{l}\text { Laboulbenia fennica n.sp. } \\ \text { Laboulbenia fennica n.sp. }\end{array} \\ 803 & 2 & & 0 & \end{array}$

$6.2 \%$

Hydrophilomyces arcuatus n.sp.

$1.1 \%$

$0.1 \%$

$2.8 \%$

36

Siemaszkoa fennica n.sp.

(6.5\%) Ecteinomyces trichopterophilus

$1443 \quad 1 \quad 0.1 \%$

$\begin{array}{rrr}38 & 1 & 2.6 \% \\ 1987 & 39 & 2.0 \%\end{array}$

$15.7 \%$

Ecteinomyces agathidii

Corethromyes niger

Corethromyces henrotii

19.6\% Asaphomyces tubanticus

Asaphomyces tubanticus Asaphomyces tubanticus Asaphomyces tubanticus

Asaphomyces tubanticus

Asaphomyces tubanticus

Rickia peyerimhoffii

Rickia peyerimhoffii

$12.3 \%$

$3.8 \%$

$60.0 \%$ (5) Teratomyces brevicaulis

(5) Diplomyces clavifer

Dichomyces furcifer Dichomyces hybridus Rhachomyces philonthinus Dichomyces furcifer Dichomyces vulgatus

(4) Dichomyces vulgatus

(1) Dichomyces princeps Rhachomyces philonthinus

(4) Rhachomyces philonthinus

(6) Dichomyces furcifer

(1) Dichomyces furcifer subsp. subarcticus n.subsp.

7.7\% Dichomyces nigrescens

(3) Dichomyces biformis

(1) Dichomyces vulgatus

(5) Dichomyces vulgatus

(1) Rhachomyces philonthinus Rhachomyces philonthinus Rhachomyces philonthinus 


\section{Host species}

Gabrius

trossulus (Nordmann)

Quedius

mesomelinus (Marsham)

cinctus (Paykull)

fuliginosus (Gravenhorst)

limbatus (Heer)

fulvicollis (Stephens)

boops (Gravenhorst)

Xantholininae

Othius

punctulatus (Goeze)

lapidicola Kiesenwetter

Paederinae

Rugilus

similis (Erichson)

Lathrobium

longulum Gravenhorst

Omaliinae

Micralymma

marinum (Ström)

Oxytelinae

Carpelimus

corticinus (Gravenhorst)

elonngatus (Erichson)

Aploderus

caesus (Erichson)

Oxytelus

fulvipes Erichson

piceus (Linnaeus)

laqueatus (Marsham)

Anotylus

insecatus (Gravenhorst)

rugosus (Fabricius)

nitidulus (Gravenhorst)

Platystethus

arenarius (Fourcroy)

Bledius

diota Schiödte

kutsae Kangas

arcticus J. Sahlberg

filipes Sharp

poppiusi Bernhauer

vilis Mäklin

longulus Erichson

opacus (Block)

gallicus (Gravenhorst)

pallipes (Gravenhorst)

Aleocharinae

Atheta

longicornis (Gravenhorst)

paracrassicornis Brundin

PSELAPHIDAE

Brachygluta

fossulata (Reichenbach)

DRYOPIDAE

Dryops

auriculatus (Fourcroy)

griseus (Erichson

CRYPTOPHAGIDAE

Cryptophagus

bimaculatus (Panzer)

pilosus Gyllenhal

setulosus Sturm \%inf. in

\section{Central}

$\Sigma \quad$ Dinf. \%inf. Europe

$\begin{array}{llll}708 & 1 & 0.1 \% & (1.8 \%)\end{array}$

$\begin{array}{rrr}280 & 23 & 8.3 \% \\ 91 & 2 & 2.2 \%\end{array}$

$4.3 \%$

$1.2 \%$

$0.5 \%$

$0.4 \%$

$0.7 \%$

$4.8 \%$

(100\%)

$38.5 \%$

191
4170

$2.4 \%$

$0.5 \%$

$0.1 \%$

40

$2.5 \%$

216

673

$1.4 \%$

$0.3 \%$

14

5894

$14.3 \%$

$-96-1.6 \%$

$35.6 \%$

(7.9\%)

$\begin{array}{lll}289 & 2 & 0.7 \%\end{array}$

2

$\begin{array}{lll}160 & 7 & 4.4 \%\end{array}$

$18 \quad 2 \quad 11.1 \%$

$591 \quad 55 \quad 9.3 \%$

$14 \quad 1 \quad 7.1 \%$

$\begin{array}{lll}724 & 11 & 1.5 \%\end{array}$

$479 \quad 1 \quad 0.2 \%$

427

$0.2 \%$

$\begin{array}{lll}37 & 3 & 8.1 \%\end{array}$

$\begin{array}{lll}3 & 1 & 25.0 \%\end{array}$

$1.7 \%$

$6.7 \%$

$1.7 \%$

$1.1 \%$

$1.5 \%$

$2.6 \%$

$1.6 \%$

$\begin{array}{rrr}35 & 1 & 2.9 \% \\ 16532 & 24(25) & 0.1 \%\end{array}$

$477 \quad 18(19) \quad 3.8 \%$

$(459)^{\mathrm{xx}} \quad 6 \quad(1.7 \%)^{\mathrm{xx})}$

$\begin{array}{rrr}1765 & 12 & 0.7 \% \\ 259 & 12 & 4.6 \% \\ 535 & 7 & 1.3 \% \\ 113 & 1 & 0.9 \% \\ 138 & 6 & 4.4 \% \\ 4069 & 7 & 0.2 \% \\ 174 & 1 & 0.6 \% \\ 238 & 4 & 1.7 \% \\ 75 & 2 & 2.7 \%\end{array}$

$65.5 \%$

0

$9.5 \%$

$26.7 \%$

$7.0 \%$

0

\section{Parasite species}

Teratomyces philonthi

Symplectromyces vulgaris

Symplectromyces vulgaris

Symplectromyces rarus n.sp.

Symplectromyces vulgaris

Symplectromyces vulgaris

Symplectromyces lapponicus n.sp.

Rhachomyces furcatus

Rhachomyces furcatus

Laboulbenia stilicicola

Euzodiomyces lathrobii

Rickia hyperborea

Cantharomyces orientalis

Cantharomyces orientalis

Cantharomyces aploderi n.sp.

Monoicomyces oxytelis n.sp.

Monoicomyces sanctae-helenae

Monoicomyces furcatus

Peyritschiella protea

Peyritschiella protea

Peyritschiella protea

Monoicomyces invisibilis

Haplomyces texanus

Haplomyces texanus

Haplomyces texanus

Haplomyces texanus

Haplomyces texanus

Haplomyces texanus

Haplomyces texanus

Haplomyces texanus

Haplomyces texanus

Haplomyces texanus

(18) Monoicomyces britannicus

(1) Amphoromorpha sp. $x$ )

Monoicomyces homalotae

Peyerimhoffiella elegans

Helodiomyces elegans

Cantharomyces italicus

Autophagomyces falcatus Autophagomyces falcatus Autophagomyces falcatus

$\mathrm{x}$ ) Belongs to Gloeohaustoriales (Deuteromycetes), see section 8.4.1.

xx) The figures for $\Sigma$ and \%inf. concerns A. crassicornis/paracrassicornis. 


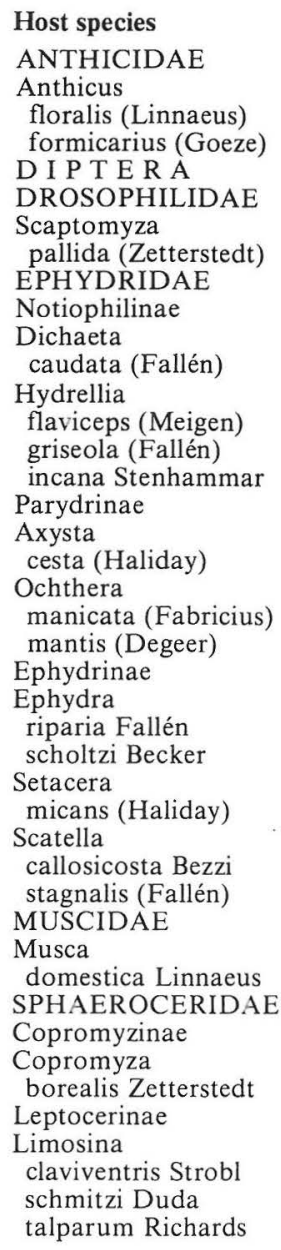

\begin{tabular}{|c|c|c|c|c|}
\hline$\Sigma$ & Einf. & \%inf. & $\begin{array}{l}\text { \%inf. in } \\
\text { Central } \\
\text { Europe }\end{array}$ & Parasite species \\
\hline 1317 & 3 & $0.2 \%$ & & \\
\hline $\begin{array}{r}102 \\
65\end{array}$ & $\begin{array}{l}2 \\
1\end{array}$ & $\begin{array}{l}2.0 \% \\
1.5 \%\end{array}$ & & $\begin{array}{l}\text { Dioicomyces anthici } \\
\text { Dioicomyces anthici }\end{array}$ \\
\hline 377 & 6 & $1.6 \%$ & & \\
\hline $\begin{array}{r}276 \\
3646\end{array}$ & $\begin{array}{r}6 \\
35\end{array}$ & $\begin{array}{l}2.2 \% \\
1.0 \%\end{array}$ & & Stigmatomyces scaptomyzae \\
\hline 188 & 1 & $0.5 \%$ & & Stigmatomyces dichaetae n.sp. \\
\hline $\begin{array}{r}56 \\
205 \\
21\end{array}$ & $\begin{array}{r}2 \\
14 \\
2\end{array}$ & $\begin{array}{l}3.6 \% \\
6.8 \% \\
9.5 \%\end{array}$ & & $\begin{array}{l}\text { Stigmatomyces hydrelliae } \\
\text { Stigmatomyces hydrelliae } \\
\text { Stigmatomyces hydrelliae }\end{array}$ \\
\hline 11 & 1 & $9.1 \%$ & & Stigmatomyces axystae n.sp. \\
\hline $\begin{array}{r}2 \\
172\end{array}$ & $\begin{array}{l}1 \\
8\end{array}$ & $\begin{array}{r}50.0 \% \\
4.7 \%\end{array}$ & & $\begin{array}{l}\text { Stigmatomyces manicatae n.sp. } \\
\text { Stigmatomyces mantis n.sp. }\end{array}$ \\
\hline $\begin{array}{l}72 \\
39\end{array}$ & $\begin{array}{l}2 \\
1\end{array}$ & $\begin{array}{l}2.9 \% \\
2.6 \%\end{array}$ & & $\begin{array}{l}\text { Stigmatomyces ephydrae } \\
\text { Stigmatomyces bottnica n.sp. }\end{array}$ \\
\hline 26 & 1 & $3.9 \%$ & & Stigmatomyces setacerae n.sp. \\
\hline $\begin{array}{r}32 \\
495 \\
285\end{array}$ & $\begin{array}{l}1 \\
1 \\
2\end{array}$ & $\begin{array}{l}3.1 \% \\
0.2 \% \\
0.7 \%\end{array}$ & & $\begin{array}{l}\text { Stigmatomyces purpureus } \\
\text { Stigmatomyces purpureus }\end{array}$ \\
\hline $\begin{array}{r}48 \\
1631\end{array}$ & $\begin{array}{r}2 \\
20\end{array}$ & $\begin{array}{l}4.2 \% \\
1.2 \%\end{array}$ & & Stigmatomyces baeri \\
\hline 101 & 1 & $1.0 \%$ & & Fanniomyces copromyzae n.sp. \\
\hline $\begin{array}{r}184 \\
45 \\
177\end{array}$ & $\begin{array}{r}3 \\
5 \\
11\end{array}$ & $\begin{array}{r}1.6 \% \\
11.1 \% \\
6.2 \%\end{array}$ & & $\begin{array}{l}\text { Stigmatomyces chthonicus n.sp. } \\
\text { Stigmatomyces hackmanii n.sp. } \\
\text { Stigmatomyces subterraneus n.sp. }\end{array}$ \\
\hline
\end{tabular}




\section{Appendix 3}

Parasite-host list of the East Fennoscandian Laboulbeniales (including Gloeohaustoriales). Parasite species as well as host species in alphabetical order. Occurrence of the parasite in the separate regions indicated for each host species. Abbreviations: $\mathrm{F}=$ Finland, $\mathrm{L}=$ Leningrad Region, $\mathrm{K}=$ Karelian A.S.S.R., $\mathrm{M}=$ Murmansk Region, $\mathrm{A}=$ Archangel Region (Solovetsk Islands). A few other records given in brackets.

Amphoromorpha sp.

(Gloeohaustroriales)
Atheta longicornis

Asaphomyces tubanticus

Catops alpinus

Catops fuliginosus

Catops fuscus

Catops nigricans

Catops nigrita

Sciodrepoides watsoni

Autophagomyces falcatus

Cryptophagus

$\begin{array}{ll}\text { bimaculatus } & \mathrm{F} \\ \text { Cryptophagus pilosus } & \mathrm{F}\end{array}$

Cryptophagus setulosus F

Cantharomyces aploderi n.sp.

Aploderus caesus

Cantharomyces italicus

Dryops griseus

Cantharomyces orientalis

Carpelimus corticinus

Carpelimus elongatulus

Chitonomyces bidessarius

Hygrotus inaequalis

Chitonomyces melanurus

Laccophilus minutus

Chitonomyces paradoxus

Laccophilus minutus

Corethromyces henrotii

Choleva septentrionis

Corethromyces niger

Ptomaphagus subvillosus $\mathrm{F} \mathrm{L}$

Dichomyces biformis

Philonthus umbratilis

F

F K

L

F

F

F

F

$\mathrm{K}$

F M

K

F

F

F

F L

Dichomyces furcifer

Philonthus albipes

Philonthus discoideus

Philonthus puella

D. furcifer subsp. subarcticus n. subsp.

Dichomyces hybridus

Philonthus debilis

Philonthus ventralis

Dichomyces nigrescens

Dichomyces princeps

Philonthus cephalotes

Dichomyces vulgatus

Philonthus cephalotes

Philonthus fuscus

Philonthus longicornis

Philonthus umbratilis

Dioicomyces anthici

Anthicus floralis

Diplomyces clavifer

Erichsonius cinerascens

( + Sweden)

Ecteinomyces agathidii

Cyrtusa subtestacea

K
Philonthus albipes

Philonthus debilis

Anthicus formicarius
Ecteinomyces trichopterophilus

Acrotrichis sp. F

Eucantharomyces fennoscandicus n.sp.

Agonum quadripuncta-

tum

Lathrobium longulum $F$

Fanniomyces copromyzae

n.sp.

Copromyza borealis

Haplomyces texanus

Bledius arcticus

Bledius diota

Bledius filipes

Bledius gallicus

Bledius kutsae

Bledius longulus

Bledius opacus

Bledius pallipes

Bledius poppiusi

Bledius vilis

F K

F

Helodiomyces elegans

Dryops auriculatus

Hydraeomyes halipli

Haliplus fulvicollis

Haliplus fulvus fulvus

Haliplus fulvus lapponum $F$

Haliplus lineolatus

$$
\text { F }
$$

M

F

M

F

M

Hydrophilomyces arcuatus n.sp.

Ochthebius minimus F

Laboulbenia argutoris

Pterostichus diligens

Laboulbenia bradycelli

Trichocellus placidus

Laboulbenia carelica n.sp.

Bembidion doris

Laboulbenia clivinalis

Clivina fossor

Laboulbenia compressa

Harpalus affinis

Harpalus latus

Harpalus tardus

Harplaus xanthopus

Laboulbenia curtipes

Bembidion dentellum

Bembidion obliquum

Bembidion semi-

punctatum

Bembidion varium

Laboulbenia elaphri

Elaphrus cupreus

Laboulbenia fasciculata

Patrobus assimilis

Patrobus atrorufus

Patrobus australis

Patrobus septentrionis

Laboulbenia fennica n.sp.

Gyrinus aeratus

Gyrinus distinctus

Gyrinus marinus
F L K

F K M

L K

F L M

F L K

F

F L

F

F

F L

L

F

F

F

F L K

F K

F

F

Gyrinus minutus
Gyrinus natator
Gyrinus paykulli
Gyrinus pullatus
Gyrinus substriatus
Laboulbenia filifera
Harpalus affinis
Laboulbenia flagellata
Agonum dolens
Agonum dorsale
Agonum fuliginosum
Agonum gracile
Agonum marginatum
Agonum quadri-
punctatum
Agonum thorey
Agonum versutum
Agonum viduum
Agonum septentrionis
Laboulbenia giardii
Dicheirotrichus
rufithorax
(Laboulbenia gyrinicola)
Gyrinus substriatus
(Sweden, CSR)

F

F

F

F L

F

F

F

L

F

F

F

F

F K

(Sweden, CSR)

Laboulbenia hastiana n.sp.

Bembidion hasti

Laboulbenia kajanensis n.sp.

Pterostichus diligens F

Laboulbenia leisti

Leistus ferrugineus

Laboulbenia manubriolata

Perigona nigriceps

Laboulbenia metableti

Syntomus truncatellus F L K

Laboulbenia murmanica n.sp.

Bembidion transparens

Laboulbenia notiophili

Notiophilus biguttatum F

Notiophilus germinyi F

Laboulbenia oodiphila $\mathrm{n}$.sp.

Oodes helopioides

Laboulbenia ophoni

Harpalus latus

Harpalus luteicornis

Harpalus tardus

Harpalus xanthopus

winkleri

Laboulbenia pedicellata

Bembidion articulatum

Bembidion doris

Bembidion gilvipes

Bembidion quadri-

maculatum

Bembidion ruficolle

F

Bembidion

semipunctatum

Dyschirius arenosus

Dyschirius globosus

Dyschirius septentrionum F L

\author{
F
}

F L

F L

F

F

F

F

L

L

L
L K A 
Laboulbenia polyphaga

Acupalpus flavicollis

Bradycellus caucasicus

Bradycellus ruficollis

Calathus erratus

Calathus melanocephalus $F$

Calathus micropterus

Laboulbenia pseudomasei

Patrobus assimilis

Patrobus septentrionis

Pterostichus minor

Pterostichus nigrita

Pterostichus strenuus

Laboulbenia pterostichi

Harpalus nigritarsis

(according to Siemaszko

\& Siemaszko 1928)

Laboulbenia pulchella

Dromius linearis

Laboulbenia stilicicola

Rugilus similis

Laboulbenia vulgaris

Bembidion assimile

Bembidion biguttatum

Bembidion bruxellense

Bembidion dentellum

Bembidion difficile

Bembidion guttula

Bembidion hasti

Bembidion saxatile

Bembidion tetracolum

Bembidion unicolor

Trechus rubens

Misgomyces dyschirii

Dyschirius globosus

Dyschirius politus

Dyschirius septentrionum

Monoicomyces britannicus

Atheta longicornis

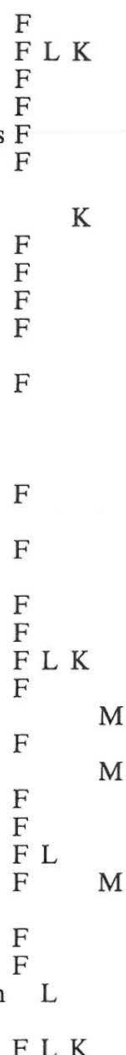

F L K
Monoicomyces furcatus

Oxytelus laqueatus

Monoicomyces homolotae

Atheta paracrassicornis

Monoicomyces invisibilis

Platystethus arenarius $\quad \mathrm{F}$

Monoicomyces oxytelis n.sp.

Oxytelus fulvipes

$F$

Monoicomyces sanctae-helenae

Oxytelus piceus

(+ Novosibirsk)

F L

Peyerimhoffiella elegans

Brachygluta fossulata

F

Peyritschiella protea

Anotylus insecatus

Anotylus nitidulus

Anotylus rugosus

Rhachomyces furcatus

Othius lapidicola

Othius punctulatus

Rhachomyces philonthinus

Philonthus albipes

Philonthus cruentatus

Philonthus fimetarius

Philonthus fulvipes

Philonthus longicornis

Philonthus micans

Rickia hyperborea

Micralymma marinum

Rickia peyerimhoffii

Scaphisoma agaricinum F L

Scaphisoma inopinatum $F$

Siemaszkoa fennica n.sp.

Ptenidium laevigatum

Stigmatomyces axystae n.sp.

Axysta cesta

Stigmatomyces baeri

Musca domestica

Stigmatomyces bottnica n.sp.

F

F
Ephydra scholtzi

$F$

F L K M

Stigmatomyces chthonicus n.sp.

Limosina claviventris $F$

Stigmatomyces dichaetae n.sp.

Dichaeta caudata

Stigmatomyces ephydrae

Ephydra riparia

Stigmatomyces hackmanii n.sp.

Limosina schmitzi

Stigmatomyces hydrelliae

Hydrellia flaviceps

Hydrellia griseola

Hydrellia incana

F K

Stigmatomyces manicatae n.sp.

Ochthera manicata

F.sp.

Stigmatomyces mantis n.sp.

Ochthera mantis

Stigmatomyces purpureus

Scatella callosicosta

Scatella stagnalis $F$

F K

Stigmatomyces scaptomyzae

Scaptomyza pallida

$\mathrm{F}$

F $\mathrm{K}$

$\mathrm{K}$

Stigmatomyces setacerae $n$.

Setacera micans F

Stigmatomyces subterraneus n.sp.

Limosina talparum

$F$

Symplectromyces lapponicus n.sp.

Quedius boops

Symplectromyces rarus n.sp.

Quedius fuliginosus

Symplectromyces vulgaris

Quedius cinctus

Quedius fulvicollis

Quedius limbatus

Quedius mesomelinus

Teratomyces brevicaulis

Erichsonius cinerascens

Teratomyces philonthi

Gabrius trossulus

\section{sp.}

F

$M$

F $\quad$ M

F K

F 